UNIVERSIDADE DE SÃO PAULO

INSTITUTO DE PSICOLOGIA

ADENILSON MATOS DO NASCIMENTO

Estudo da influência da prática com as artes cênicas

e atividade autobiográfica e literária no comportamento

de uma população com idade acima de 60 anos

São Paulo

2013 


\title{
Estudo da influência da prática com as artes cênicas e atividade autobiográfica e literária no comportamento de uma população com idade acima de 60 anos
}

\author{
(VERSÃO CORRIGIDA)
}

Tese apresentada ao Instituto de Psicologia da Universidade de São Paulo como parte dos requisitos para obtenção do título de Mestre em Psicologia.

Área de concentração:

Neurociências e Comportamento

Orientadora:

Prof $^{a}$. Dra. Maria Inês Nogueira

\section{SÃO PAULO}

2013 


\begin{abstract}
AUTORIZO A REPRODUÇÃO E DIVULGAÇÃO TOTAL OU PARCIAL DESTE TRABALHO, POR QUALQUER MEIO CONVENCIONAL OU ELETRÔNICO, PARA FINS DE ESTUDO E PESQUISA, DESDE QUE CITADA A FONTE.
\end{abstract}

Catalogação na publicação

Biblioteca Dante Moreira Leite

Instituto de Psicologia da Universidade de São Paulo

Nascimento, Adenilson Matos do.

Estudo da influência da prática com as artes cênicas e atividade autobiográfica e literária no comportamento de uma população com idade acima de 60 anos / Adenilson Matos do Nascimento; orientadora Maria Inês Nogueira. -- São Paulo, 2013.

$198 \mathrm{f}$.

Dissertação (Mestrado - Programa de Pós-Graduação em Psicologia. Área de Concentração: Neurociências e Comportamento - Instituto de Psicologia da Universidade de São Paulo.

1. Neurociências 2. Artes cênicas 3. Saúde 4. Idosos 5. Envelhecimento 6. Motivação 7. Inclusão Social I. Título.

QP355 
Nome: Adenilson Matos do Nascimento

Título: Estudo da influência da prática com as artes cênicas e atividade autobiográfica e literária no comportamento de uma população com idade acima de 60 anos.

Dissertação apresentada ao Instituto de Psicologia da Universidade de São Paulo como parte dos requisitos para obtenção do título de Mestre em Psicologia.

Aprovado em: 01 de outubro de 2013.

Banca Examinadora

Profa. Dra. Maria Inês Nogueira

Instituição: Instituto de Ciências Biomédicas da USP. Assinatura:

Prof. Dr. Marcelo da Costa Fernandes

Instituição: Instituto de Psicologia da USP.

Assinatura:

Profa. Dra. Isabela Judith Martins Benseñor

Instituição: Faculdade de Medicina da USP.

Assinatura: 


\section{DEDICATÓRIA}

A minha esposa Luciana Cah e a meus filhos,

Ananta Daneu do Nascimento e Pedro Paulo Raphaelian Cardoso Matos do Nascimento, entes generosos, acolhedores, compreensivos e inspiradores. 


\section{AGRADECIMENTOS}

Há prazer maior do que o da realização? Por isso mesmo, o sentimento de gratidão invade todos os meus atos e pensamentos nesse momento para dizer o quanto as contribuições e atitudes de apoio e incentivo de diversas pessoas foram importantes para a realização desta tese. Difícil enumerá-las todas aqui e se, por acaso, alguém não for citado, tenha a certeza de que sua colaboração faz parte desta alegria.

Ao professor Marcelo Fernandes Costa, coordenador do Programa de Neurociências e Comportamento do Instituto de Psicologia da Universidade de São Paulo.

Agradeço a minha orientadora, professora Maria Inês Nogueira, que desde o seu primeiro contato com o projeto Só Com Experiência e consultoria ao espetáculo "Larguem Tudo. Vamos Voar!" vislumbrou essa pesquisa e me incentivou a realizá-la. Com o olhar de alguém que realmente assume os aspectos mais livres e edificantes da academia, ela não teve dúvida em apostar na tríade Neurociência, Artes Cênicas e Saúde feita por um ator, bailarino e diretor de teatro. Haja coragem e ampla percepção das possibilidades da produção científica.

A meu pai, meus irmãos, sobrinhos e, em especial, a minha mãe, Irene Matos do Nascimento (in memorian), pessoa simples e de pouca formação, mas com interesse sobre as "coisas do mundo" superior a muitas pessoas que delas fazem sua profissão. Ela foi a minha grande incentivadora desde os meus primeiros passos na escola: "Um dia você vai ajudar outras pessoas com os seus estudos".

Ao atencioso, amigo, parceiro e exemplar grupo de pesquisa do Laboratório de Neurociências e Comportamento do Departamento de Anatomia do Instituto Ciências Biomédicas da USP: Bárbara Milan Martins, Francisco Rômulo Monte Ferreira, Leila Campos Guissoni, Marcelo Muniz, Mike Yoshio Hamasaki, Renné Panduro Alegrias, Silvia Honda Takada, Vitor Yonamine Lee e, especialmente, Neuza Guerreiro de Carvalho.

Aos funcionários e professores do Programa de Neurociências e Comportamento do Instituto de Psicologia da USP, pelo apoio, incentivo e oportunidades de aprendizagem. 
Às professoras Amélia Império Hamburger (in memorian) e Dilma de Melo Silva, pelo apoio incondicional às iniciativas do Núcleo de Artes Cênicas da Estação Ciência.

Aos funcionários da Estação Ciência, pelo apoio operacional e executivo, em especial a Carlos Fernando Pedroso, ao Marcos Matsukuma e Dirce Pranzetti.

Aos diretores da Estação Ciência: Ernst W. Hamburger, Roseli de Deus Lopes, Mikiya Muramatsu, Wilson Teixeira e Saulo Ramos, pela abertura de caminhos, fomento e apoio às atividades do Núcleo de Artes Cênicas.

Aos estagiários Norton Felipe dos Santos Silva e Flávio Henrique Sarti Benatti pelo interesse e cuidados sobre a pesquisa e pesquisados, mas principalmente pela amizade feita.

Aos professores das disciplinas de pós-graduação cursadas por mim, por mostrarem, direta e indiretamente, as possibilidades de conexões entre os ensinamentos disponibilizados e o meu foco de estudo.

A todos os disponíveis e parceiros voluntários desta tese.

Agradecimento especial à funcionária do Instituto de Ciências Biomédicas, Rosana Prisco, por sua dedicação, profissionalismo e capacidade de transformar práticas em dados estatísticos.

À equipe de colaboradores que antes de tudo se constituiu num grupo de amigos, que muito me incentivaram e abriram espaços e horizontes para essa pesquisa ser finalizada: Prof. Dr. Cássio M. C. Bottino, Profa. Dra. Isabela Judith M. Benseñor, Profa. Renata Cereda Cordeiro, Profa. Dra. Fernanda Miranda da Cruz.

Aos meus professores de práticas corporais: Alex Ratton, Alexandre Tripiciano, Diogo Granato, Mestre Janja e, em especial, Líbero Malavoglia, professor de Aikido que chegou no momento certo para trabalhar minhas articulações e transformar o peso da caminhada em atos de respiração. 
"A ciência, a arte, é o saber. O não saber é mistério, esperança." Amélia Império Hamburger 


\section{RESUMO}

NASCIMENTO, A. M. Estudo da influência com a prática das artes cênicas e da atividade autobiográfica e literária no comportamento de uma população com idade acima de 60 anos. 2013. 198 f. Tese (Mestrado) - Instituto de Psicologia. Universidade de São Paulo, São Paulo, 2013.

O envelhecimento é um processo inexorável a qualquer ser vivo e, no caso do ser humano, objeto deste estudo, os efeitos são acentuados a partir da faixa etária superior a 60 anos de idade, quando naturalmente se acentua o declínio das capacidades motoras, mentais e sociais de forma contínua, progressiva e inter-relacionada. Este estudo, envolvendo neurociências, artes cênicas e saúde, surgiu da preocupação com a crescente população de idosos hoje no Brasil e no mundo, assim como da busca de recursos que propicie melhor qualidade de vida a essa faixa etária. Para tanto, foi realizado estudo sistemático relacionado à memória, corpo e movimento, envolvendo estratégias de trabalho autobiográfico, literário e cênico, no intuito de compreender a dinâmica de alguns parâmetros cognitivos, físicos e comportamentais dessa faixa etária, assim como verificar sua influência na superação de desafios sociais, conflitos emocionais e eventuais ganhos funcionais. Participaram do estudo, inicialmente, 27 voluntários com idade superior a 60 anos, socialmente ativos, de ambos os sexos, moradores da cidade de São Paulo, SP, Brasil. Os grupos foram denominados Grupo 1 (G1), composto por 12 pessoas, e Grupo 2 (G2), composto por 15 indivíduos. Com o G1 foram desenvolvidas atividades baseadas na memória individual que foi resgatada por diversas abordagens e com as quais foi composto por cada participante um livro autobiográfico, enquanto ao G2 foram oferecidos conhecimento e prática da atividade cênica. Os voluntários foram avaliados individualmente no pré- e pós-teste por meio dos questionários: Informações Sociodemográficas, World Health Organization Quality of Life - WHOQOL-Bref e WHOQOL-OLD; Cambridge Cognitive Test - CAMCOG; por exames clínicos: medidas antropométricas, dosagem do colesterol total, HDL-colesterol, Colesterol LDL, triglicérides, glicemia, hemograma completo e eletrocardiograma; exames funcionais: Timed Up and Go Test-TUGT, Six-Minute Walk Test, One-Leg Balance Test; entrevistas, fotos, registros em vídeo, depoimentos e questionários de opinião. O Questionário de Avaliação Final da Atividade recorreu à Escala Likert para a estruturação das perguntas. $\mathrm{O}$ estudo foi realizado entre agosto de 2011 e janeiro de 2012, no teatro da Estação Ciência - USP, São Paulo. Seus resultados indicaram relativas alterações positivas dentro dos grupos, entre os pré- e póstestes, e permitem concluir que a atividade autobiográfica e a de artes cênicas, para a população com idade acima de 60 anos, são recursos promotores da saúde e melhor qualidade de vida. Esse estudo, por seus resultados positivos, valida a prática em artes cênicas como proposta de atividade promotora de motivação e sociabilidade em pessoas com faixa etária acima de 60 anos de idade, e, principalmente, por trabalhar aspectos motores do deslocamento, postura e equilíbrio corporais que além de promoverem saúde, adquirem função preventiva à quedas.

Palavras-chave: Neurociências. Artes cênicas. Saúde. População idosos. Envelhecimento populacional. Motivação. Inclusão social. 


\begin{abstract}
NASCIMENTO, A. M. Study of the Influence of the practice of the performing arts and the autobiographical and literary activities in the behavior of a population aged over 60 years. 2013. 198 f. Tese (Mestrado) - Instituto de Psicologia. Universidade de São Paulo, São Paulo, 2013.
\end{abstract}

Aging is an inevitable process for any living being, and in the case of the human being, the object of this study, the effects are accentuated from the age group above 60 years of age, when there is a naturally and continuous decline of motor, mental and social skills, in a progressive and interrelated form. This study, involving neurosciences, performing arts and health, arose from the general concern over the growing elderly population today in Brazil as well as in the world, the search for resources that provides better quality of life for this age group. Therefore, we performed a systematic study related to memory, body and movement, involving strategies autobiographical work, literary and scenic in order to understand the dynamics of some parameters cognitive, behavioral and physical in this age group, as well as determining its influence in overcoming of social, emotional conflicts and possible functional gains. Participants were initially volunteers aged 27 to 60 years old, socially active, of both sexes, residents of the city of São Paulo, SP, Brazil. The groups were designated Group 1 (G1), composed of 12 people, and Group 2 (G2), consisting of 15 individuals. With the G1 activities were developed based on memory that was rescued by several approaches and which was composed by each participant an autobiographical book, while the G2 were offered knowledge and practice of theatrical activity. The volunteers were evaluated individually in pre - and post - test by means of questionnaires: Sociodemographic Information, World Health Organization Quality of Life - WHOQOL - Bref and WHOQOL OLD; Cambridge Cognitive Test - CAMCOG; clinical examination: Anthropometric measurements, measurement of total cholesterol, HDL cholesterol, LDL cholesterol, triglycerides, glucose, complete blood count and electrocardiogram; functional tests: Timed Up and Go Test - TUGT, Six - Minute Walk Test, One - Leg Balance Test, interviews, photos, video recordings, statements and opinion questionnaires. The Assessment Questionnaire Final Activity resorted to Likert Scale for structuring questions. The study was conducted between August 2011 and January 2012, the theater of the Science Station - USP, São Paulo. Their results indicated positive changes related within groups between the pre and post - tests, and showed that the autobiographical activity and performing arts, for the population aged over 60 years, are resources that promote health and better quality of life. This study, by its positive results, validates the practice in theater arts as proposed activity to promote motivation and sociability in people aged over 60 years of age, and especially for motor aspects of the work shift, posture and body balance that in addition to promoting health, preventive function acquire the falls.

Keywords: Neuroscience. Performing arts. Health. Elderly. Aging population. Motivation. Social inclusion. 


\section{LISTA DE FIGURAS}

Figura 1. Fotografia com os primeiros integrantes do Núcleo de Artes Cênicas da Estação Ciência. Fonte: arquivo NACEC. Em destaque, os professores Amélia Império Hamburger e Ernst W. Hamburger. (2000).

Figura 2. Fotografia com os integrantes do Projeto Só com Experiência - pesquisa cênica para pessoas com idade acima de 60 anos. Fonte: arquivo NACEC. (2009) .......21

Figura 3. Fotografia da aula introdutória do curso "Encontros para resgate de memória autobiográfica" com voluntários da $3^{\underline{a}}$ idade - Grupo 1. Fonte: arquivo NACEC. (2011)

Figura 4. Fotografia de estudos sistêmicos, anatômicos e de ideokinésis com voluntários da $3^{\mathrm{a}}$ idade, integrantes do Grupo 2. Fonte: arquivo NACEC. (2011)....

Figura 5. Fotografia de registro da aula de improvisação cênica corporal com voluntários da $3^{\mathrm{a}}$ idade, integrantes do Grupo 2. Fonte: arquivo NACEC. (2011)

Figura 6. Fotografia de narrativas em situação cênica com voluntários da $3^{\mathrm{a}}$ Idade, integrantes do Grupo 2. Fonte: arquivo NACEC. (2011)...

Figura 7. Fotografia do público aplaudindo a apresentação do espetáculo "Histórias de Mulheres", no Teatro Ernst W. Hamburger (Estação Ciência - USP), realizado pelos voluntários da $3^{\mathrm{a}}$ idade, integrantes do Grupo 2. Fonte: arquivo NACEC. (2012).

Figura 8. Fotografia de voluntário da $3^{\mathrm{a}}$ idade, integrantes do Grupo 2, participando do Timed Up and Go Test. Fonte: arquivo NACEC. (2011)

Figura 9. Fotografia de voluntário da $3^{\mathrm{a}}$ idade, integrante do Grupo 2, participando do The Six-Minutes Walk Test. Fonte: arquivo NACEC. (2011).

Figura 10. Fotografia de voluntária da $3^{\mathrm{a}}$ idade, integrante do Grupo 1, participando do OnLeg Balance Test. Fonte: Arquivo NACEC. (2011).

Figura 11. Valores individuais, Inicial e Final, dos domínios Físico, Psicológico, Social, Ambiental e Qualidade de Vida dos voluntários da $3^{\mathrm{a}}$ idade, integrantes do Grupo 1, avaliados pelo WHOQOL-Bref.

Figura 12. Valores individuais, Inicial e Final, dos domínios Físico, Psicológico, Social, Ambiental e Qualidade de Vida dos voluntários da $3^{\text {a }}$ idade, integrantes do Grupo 2, avaliados pelo WHOQOL-Bref.....

Figura 13. Valores individuais, Inicial e Final, das facetas Funcionamento dos Sentidos, Autonomia, Atividades Passadas, Presentes e Futuras, Participação Social, Morte e Morrer, Intimidade, e Global avaliadas pelo WHOQOL-OLD, obtidos a partir das respostas fornecidas pelos voluntários da $3^{\underline{a}}$ idade integrantes do Grupo $1 \ldots 88$ 
Figura 14. Valores individuais, Inicial e Final, das facetas Funcionamento dos Sentidos, Autonomia, Atividades Passadas, Presentes e Futuras, Participação Social, Morte e Morrer, Intimidade, e Global avaliadas pelo WHOQOL-OLD, obtidos a partir das respostas fornecidas pelos voluntários da $3^{\mathrm{a}}$ idade integrantes do Grupo 2 ...90

Figura 15. Autoavaliação final do desempenho Postural dos voluntários da $3^{\mathfrak{a}}$ idade - Grupo 2 .

Figura 16. Autoavaliação final do desempenho de Movimento corporal dos voluntários da $3^{\mathrm{a}}$ idade - Grupo 2.

Figura 17. Autoavaliação final do desempenho de Flexibilidade dos voluntários da $3^{\mathrm{a}}$ idade Grupo 2.

Figura 18. Autoavaliação final do desempenho de Atenção dos voluntários da $3^{\underline{a}}$ idade Grupo 2

Figura 19. Autoavaliação final do desempenho de Memória dos voluntários da $3^{\text {a }}$ idade Grupo 2 . 100

Figura 20. Autoavaliação final do desempenho de Motivação dos voluntários da $3^{\text {a }}$ idade Grupo 2 100

Figura 21. Autoavaliação final do desempenho Emocional dos voluntários da $3^{\text {a }}$ idade Grupo 2.

Figura 22. Autoavaliação final do desempenho de Relacionamento dentro do Grupo de voluntários da $3^{\mathrm{a}}$ idade - Grupo 2 101

Figura 23. Autoavaliação final de desempenho de Relacionamento dos voluntários da $3^{\mathrm{a}}$ idade com a Família - Grupo 2

Figura 24. Autoavaliação final do desempenho de Relacionamento dos voluntários da $3^{\mathrm{a}}$ idade com Amigos - Grupo 2.

Figura 25. Autoavaliação final do desempenho da Saúde dos voluntários da $3^{\text {a }}$ idade - Grupo 2.

Figura 26. Fotografia do Teatro Ernst W. Hamburger. - Estação Ciência - USP e participantes do Projeto Só com Experiência. Fonte: arquivo NACEC. (2008). 198 


\section{LISTA DE QUADROS}

Quadro 1. Aspectos envolvidos e trabalhados na pratica cênica com voluntários da $3^{\mathrm{a}}$ Idade -

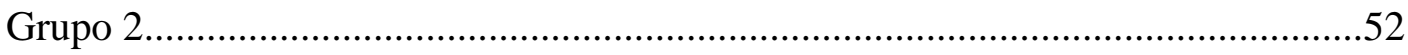

Quadro 2. Relação IMC e Risco de doença.......................................................................65

Quadro 3. Relação da Circunferência Abdominal e RCQ e Risco de Doença..........................65 


\section{LISTA DE TABELAS}

Tabela 1. Perfil sociodemográfico dos voluntários em gênero, idade, altura e peso da $3^{\mathrm{a}}$ Idade, pertencentes ao Grupo 1 e Grupo 2. .

Tabela 2. Perfil sociodemográfico: identificação sócio econômico e cultural dos voluntários da $3^{\underline{a}}$ idade, pertencentes ao Grupo 1 e Grupo 2, expressas em freqüência.

Tabela 3. Perfil sociodemográfico: atividades de lazer dos voluntários da $3^{\text {a }}$ Idade, pertencentes aos Grupo 1 e Grupo 2, , expressas em freqüência. .74

Tabela 4. Perfil sociodemográfico: percepção de saúde dos voluntários da $3^{\text {a }}$ idade pertencentes aos Grupo 1 e Grupo 2, , expressa em freqüência.

Tabela 5. Perfil sociodemográfico: atividade física e percepção motora dos voluntários da $3^{\mathrm{a}}$ Idade, pertencentes aos Grupo 1 e Grupo 2, expressas em freqüência. .76

Tabela 6. Perfil sociodemográfico: percepção cognitiva dos voluntários da $3^{\mathrm{a}}$ idade pertencentes aos Grupo 1 e Grupo 2, expressa em freqüência.

Tabela 7. Capacidade funcional dos voluntários da $3^{\text {a }}$ idade, pertencentes aos Grupo 1 e Grupo 2, expressas como média \pm desvio padrão. 78

Tabela 8. Média e desvio padrão dos valores referentes aos Domínios Físico, Psicológico, Social, Meio Ambiente e Qualidade de Vida, avaliados pelo WHOQOL-Bref, dos voluntários da $3^{\mathrm{a}}$ Idade, integrantes do Grupo 1.

Tabela 9. Média e desvio padrão referentes aos valores dos Domínios Físico, Psicológico, Social, Meio Ambiente e Qualidade de Vida, avaliados pelo WHOQOL-Bref, dos voluntários da $3^{\mathrm{a}}$ Idade, integrantes do Grupo 2.

Tabela 10. Média e desvio padrão dos valores das Facetas Funcionamento dos Sentidos, Autonomia, Atividades Passadas, Presentes e Futuras, Participação Social, Morte e Morrer, Intimidade e Global avaliadas pelo WHOQOL-OLD, obtidos a partir das respostas fornecidas pelos voluntários da $3^{\mathrm{a}}$ idade, integrantes do Grupo 1 ...86

Tabela 11. Média e desvio padrão dos valores das Facetas Funcionamento dos Sentidos, Autonomia, Atividades Passadas, Presentes e Futuras, Participação Social, Morte e Morrer, Intimidade e Global avaliadas pelo WHOQOL-OLD, obtidos a partir das respostas fornecidas pelos voluntários da $3^{\underline{a}}$ idade, integrantes do Grupo 2...87

Tabela 12. Valores obtidos com o Cambridge Cognitive Test-CAMCOG, e Mini Exame do Estado Mental - MEEM, a partir das respostas fornecidas pelos voluntários da $3^{\mathrm{a}}$ idade, integrantes do Grupo 1

Tabela 13. Valores obtidos com o Cambridge Cognitive Test-CAMCOG, e Mini Exame do Estado Mental - MEEM, a partir das respostas fornecidas pelos voluntários da $3^{\text {a }}$ idade, integrantes do Grupo 2 
Tabela 14. Índice no início da pesquisa da Massa Corporal - IMC - dos voluntários da $3^{\text {a }}$ idade, integrantes do Grupo 1

Tabela 15. Índice no início da pesquisa da Massa Corporal - IMC - dos voluntários da $3^{\mathrm{a}}$ idade, integrantes do Grupo 2

Tabela 16. Índice no início da pesquisa da Circunferência Abdominal e RCQ dos voluntários da $3^{\mathrm{a}}$ idade, integrantes do Grupo 1

Tabela 17. Índice no início da pesquisa da Circunferência Abdominal e RCQ - dos voluntários da $3^{\mathrm{a}}$ idade, integrantes do Grupo 2

Tabela 18. Pressão arterial no início da pesquisa dos voluntários da $3^{\mathrm{a}}$ idade, integrantes do Grupo 1 .96

Tabela 19. Pressão arterial no início da pesquisa dos voluntários da $3^{\underline{a}}$ idade, integrantes do Grupo 2. ..97 


\section{LISTA DE ABREVIATURAS}

\begin{tabular}{|c|c|}
\hline AUT & Autonomia (faceta) \\
\hline CAMDEX & Cambridge Examination for Mental Disorders of the Elderly \\
\hline CAMCOG & Cambridge Cognitive Test \\
\hline CEP & Comitê de Ética em Pesquisa \\
\hline DA & Domínio Autonomia \\
\hline DF & Domínio Físico \\
\hline DP & Domínio Psicológico \\
\hline DS & Domínio Social \\
\hline FM & Faculdade de Medicina \\
\hline FS & Funcionamento dos Sentidos \\
\hline HU & Hospital Universitário \\
\hline IBGE & Instituto Brasileiro de Geografia e Estatística \\
\hline INT & Intimidade (faceta) \\
\hline IMC & Índice de Massa Corporal \\
\hline IP & Instituto de Psicologia \\
\hline $\mathrm{IPq}$ & Instituto de Psiquiatria \\
\hline IS & Informações Sociodemográficas \\
\hline MAPA & Monitorização ambulatorial da pressão arterial \\
\hline MEEM & Mini Exame do Estado Mental \\
\hline MEM & Morte e Morrer (faceta) \\
\hline MI & Movimento Involuntário \\
\hline MRPA & Monitorização residencial da pressão arterial \\
\hline MV & Movimento Voluntário \\
\hline MS & Ministério da Saúde \\
\hline NACEC & Núcleo de Artes Cênicas da Estação Ciência \\
\hline $\mathrm{NE}$ & Neurônio Espelho \\
\hline NEC & Neurociências e Comportamento \\
\hline OMS & Organização Mundial da Saúde \\
\hline PRCEU & Pró-Reitoria de Cultura e Extensão Universitária \\
\hline PPF & Passado, Presente e Futuro (faceta) \\
\hline PSO & Participação Social (faceta) \\
\hline PROTER & Projeto Terceira Idade \\
\hline PSCE & Projeto Só com Experiência \\
\hline QV & Qualidade de Vida \\
\hline $\mathrm{RCQ}$ & Relação Cintura Quadril \\
\hline SBC & Sociedade Brasileira de Cardiologia \\
\hline SBEM & Sociedade Brasileira de Endocrinologia e Metabologia \\
\hline $\mathrm{SN}$ & Sistema Nervoso \\
\hline SNA & Sistema Nervoso Autônomo \\
\hline SNC & Sistema Nervoso Central \\
\hline SNP & Sistema Nervoso Periférico \\
\hline SNV & Sistema Neurovegetativo \\
\hline TCLE & Termo de Consentimento Livre e Esclarecido \\
\hline TUGT & Timed Up and Go Test \\
\hline TC-6 & Teste de caminhada de seis minutos \\
\hline WHOQOL & World Health Organization Quality of Life \\
\hline UBS & Unidade Básica de Saúde \\
\hline USP & Universidade de São Paulo \\
\hline
\end{tabular}




\section{SUMÁRIO}

$\begin{array}{ll}\text { RESUMO } & 9\end{array}$

$\begin{array}{ll}\text { ABSTRACT } & 10\end{array}$

$\begin{array}{ll}\text { LISTA DE FIGURAS } & 11\end{array}$

$\begin{array}{ll}\text { LISTA DE QUADROS } & 13\end{array}$

$\begin{array}{ll}\text { LISTA DE TABELAS } & 14\end{array}$

$\begin{array}{ll}\text { LISTA DE ABREVIATURAS } & 16\end{array}$

$\begin{array}{ll}\text { 1. INTRODUÇÃO } & 19\end{array}$

$\begin{array}{ll}\text { 1.1. Enfoque da pesquisa } & 19\end{array}$

1.2. Artes cênicas, emoção e o idoso 22

1.3. Sistema nervoso e as artes cênicas $\quad 26$

$\begin{array}{ll}\text { 1.3.1 Movimento } & 28\end{array}$

1.3.2 Memória $\quad 29$

$\begin{array}{ll}\text { 1.3.3 Aprendizado } & 30\end{array}$

1.3.4 Atenção 31

1.3.5 Emoções $\quad 32$

1.4. Arte, ciência e saúde 36

2. JUSTIFICATIVA 45

3. OBJETIVO 47

3.1. Objetivos específicos $\quad 47$

4. MATERIAL E MÉTODOS 48

4.1. Dificuldades metodológicas $\quad 68$

5. RESULTADOS

6. DISCUSSÕES 106

7. CONCLUSÕES 126

$\begin{array}{ll}\text { REFERÊNCIAS } & 127\end{array}$

$\begin{array}{ll}\text { APÊNDICES } & 144\end{array}$

APÊNDICE I - Carta de Aprovação - Projeto de Pesquisa - CEP-HU-USP 145

APÊNDICE II - Termo de Consentimento Livre e Esclarecido (TCLE) 146

APENDICE III - Questionário Informações Sociodemográficas 149

APÊNDICE IV - Depoimento 1 - O que faço atualmente e por que resolvi 153 Fazer Teatro

APENDICE V - Depoimento 2 - Narrativa "Um fato marcante na minha 154 vida". 
APÊNDICE VI - Questionário WHOQOL-Bref 155

$\begin{array}{ll}\text { APÊNDICE VII - Questionário WHOQOL-OLD } & 158\end{array}$

APÊNDICE VIII - Folha de Respostas - CAMCOG 163

APÊNDICE IX - Valores máximos para as subáreas do CAMCOG 164

APÊNDICE X - Descrição das pontuações individuais por subáreas do 165

CAMCOG dos voluntários

$\begin{array}{lll}\text { APÊNDICE XI - Questionário de avaliação do curso } & 168\end{array}$

APÊNDICE XII - Questionário de 8 perguntas (Entrevista em vídeo) 169

APÊNDICE XIII - Questionário de quatro perguntas (Entrevista de 170 encerramento da atividade com gravação em vídeo)

APÊNDICE XIV - Questionário de Avaliação Final - Escala Likert 171

APÊNDICE XV - Ficha triagem - Idosos - One-leg balance test 172

APÊNDICE XVI - Ficha Triagem - Idosos - Testes Timed Up Go Test e Six- 173 Minute Walk Test

APÊNDICE XVII - Transcrição Depoimento 1 - “o que faço atualmente e por 175 que resolvi fazer teatro"

APÊNDICE XVIII - Transcrição do Depoimento 2 - Narrativa "Fato marcante 178 na minha vida"

APÊNDICE XIX - Questionário com 8 perguntas (entrevista em video) 181

APÊNDICE XX - Questionário com 4 perguntas (gravação em vídeo) 185

$\begin{array}{lll}\text { ANEXOS - } & \text { Peças de divulgação e matérias de jornal } & 187\end{array}$

$\begin{array}{lll}\text { ANEXO I - } \quad \text { Flyer divulgação para recrutamento de voluntários } & 188\end{array}$

$\begin{array}{lll}\text { ANEXO II - } & \text { Divulgação no site da PrCEU-USP }\end{array}$

ANEXO III - Divulgação da apresentação "Histórias de Mulheres" na 190

ANEXO IV - $\quad$ Revista Carta Capital (Matéria sobre a peça "Histórias de 191

$\begin{array}{lll} & \text { Mulheres”, apresentação no Cube Pinheiros } \\ \text { ANEXO V - } & \text { Divulgação do projeto Só Com Experiência no Diário } & 192\end{array}$

Oficial

ANEXO VI - $\quad$ Revista da Folha - Matéria sobre o Projeto Só com 193

Experiência - pesquisa cênica para pessoas com idade acima de 60 anos.

GLOSSÀRIO 


\section{INTRODUÇÃO}

\subsection{Enfoque da pesquisa}

Entre 2000 e 2011, o Núcleo de Artes Cênicas da Estação Ciência, órgão pertencente à Pró-Reitoria de Cultura e Extensão Universitária da Universidade de São Paulo, desenvolveu estudos e práticas visando à interface Ciência, Arte e Educação, utilizando recursos como publicações, artigos, criação de textos teatrais, pesquisa corporal, cênica, produção e apresentação de espetáculos. Num primeiro momento, esses estudos e práticas estavam voltados sistematicamente à utilização dos recursos cênicos como meio para difundir e promover as várias áreas do saber, da ciência. Resultados como os espetáculos “A Estrela da Manhã" e "Conexões Cósmicas", das aulas espetáculos "Professor Gervásio e a Energia Elétrica" e "Tecnophatos", ou mesmo do livro "Ciência e arte - imaginário e descoberta" (Matos, 2003), entre outras iniciativas, representaram as várias possibilidades de atuação do Núcleo de Artes Cênicas de forma acentuada.

Repertório do Núcleo: Apresentados pela Cia. Fábula da Fíbula: "A Estrela da Manhã" (2000), de Calixto de Inhamuns, direcão de Gabriela Rabelo; "Conexões Cósmicas" (2003), autoria e direção Wilton Amorim; "Gestação" (2004), de Tânia Fraga e direção de Cauê Mattos; "Prof. Gervásio e a Energia Elétrica" (2004), de Cauê Mattos e Regina Arruda, direção Regina Arruda; "O Monocórdio de Pitágoras" (2004), de Pedro Paulo Salles, direção Cauê Mattos; "Marte, a Viagem" (2004), autoria e direção Renata Soffredini; "O Poeta e o Vento" (2005), de Calixto de Inhamuns, direção Gabriela Rabelo; "Larguem Tudo, Vamos Voar!” (2006), autoria e direção Darci Figueiredo.

Mattos.

Apresentados por estudantes/monitores da Estação Ciência: "O Rio, o poeta e a cidade" (2009), de Roseli Imbernon, direção Cauê Apresentados pelo Projeto Só com Experiência: "Sonhos" (2007), criação coletiva, direção Cauê Mattos; "O Pagador de Promessa" (2009), de Dias Gomes, direção Cauê Mattos; "Sonho de Uma Noite de Verão" (2010), de W. Shakespeare, direção Cauê Mattos; "O poeta, o rio e a cidade" (2011), concepção e direção de Cauê Mattos; "Paixão e Eternidade" (2011), criação coletiva, direção Cauê Mattos e "Ver São Muitos" (2011), criação coletiva e direção de Cauê Mattos. 


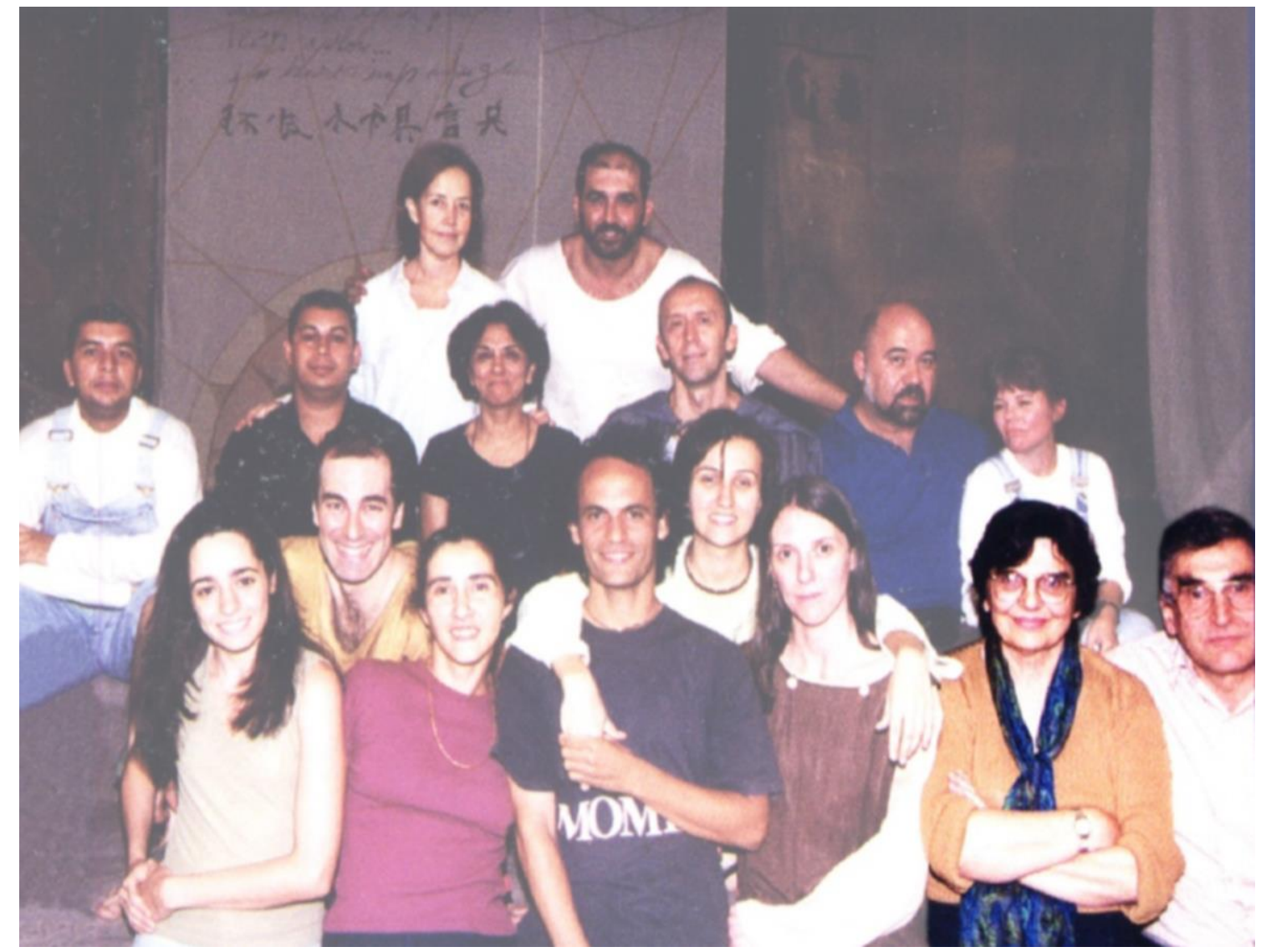

Figura 1. Fotografia com os integrantes iniciais do Núcleo de Artes Cênicas da Estação Ciência. Fonte: NACEC. Em destaque, os professores Amélia Império Hamburger e Ernst W. Hamburger. (2000).

Porém, com a pesquisa e produção do espetáculo "Larguem tudo, Vamos Voar!"2, o objeto do estudo e prática passou a ser o próprio fazer cênico e o ator/atriz. Desta forma, surgiu um novo campo de atuação para o Núcleo de Artes Cênicas, no qual é incluída a iniciativa dirigida à população idosa, o Projeto Só com Experiência.

2 Espetáculo criado e dirigido por Darci Figueiredo, produzido especialmente para comemorar o centenário do voo do 14 Bis, narra de forma livre a vida e invenções de Alberto Santos Dumont. Ele estreou em junho de 2006 e ficou em temporada até junho de 2010 , quando participou das comemorações dos 10 anos do Núcleo de Artes Cênicas da Estação Ciência. 


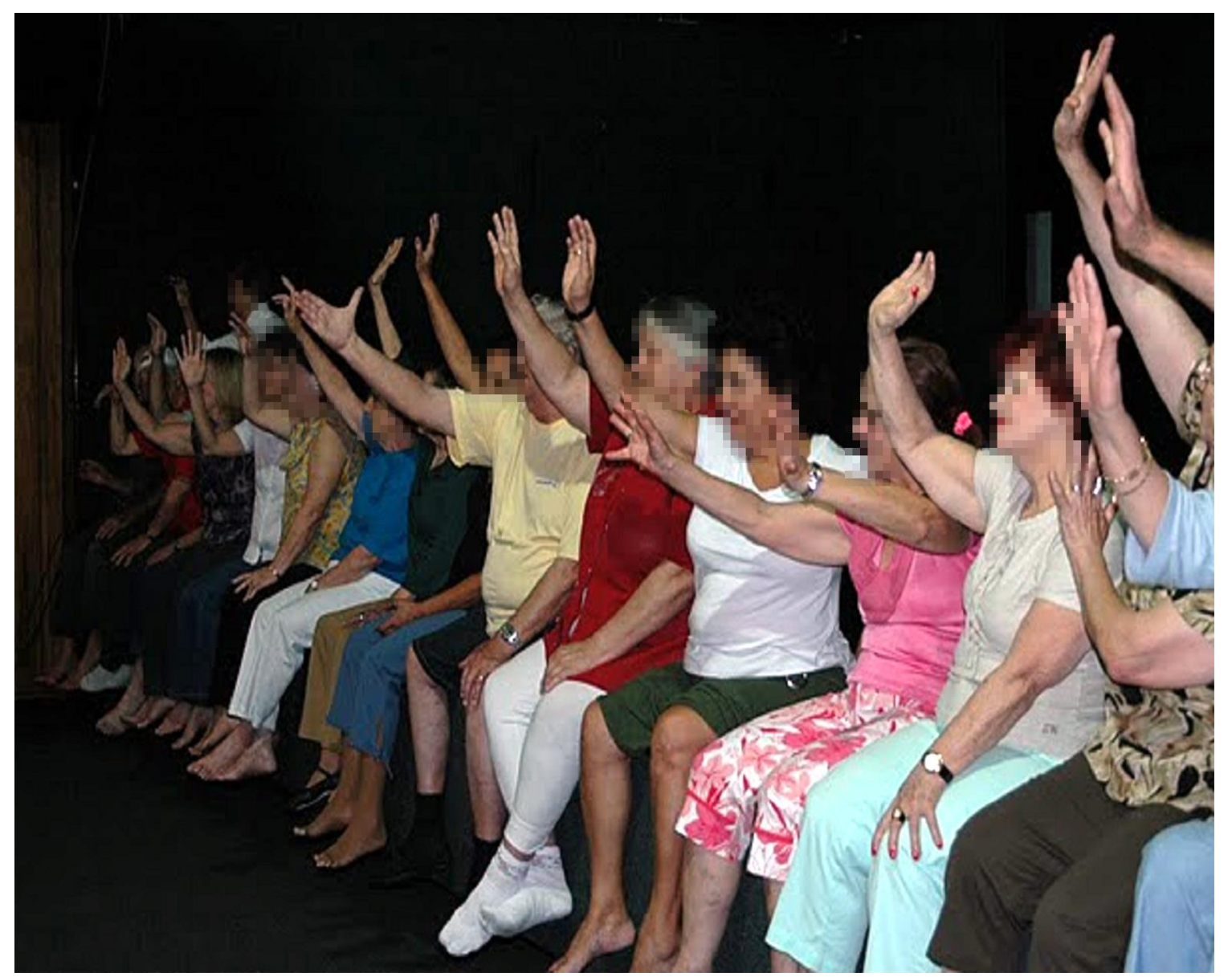

Figura 2. Fotografia com os integrantes do Projeto Só com Experiência - Pesquisa Cênica para pessoas com idade acima de 60 anos. Fonte: arquivo NACEC. (2009)

O Projeto Só com Experiência - Pesquisa Cênica para pessoas acima de 60 anos de idade iniciou suas atividades em agosto de 2007, integrando o quadro de atividades do Programa Universidade Aberta à Terceira Idade, organizado e coordenado pela Pró-Reitoria de Cultura e Extensão Universitária da Universidade de São Paulo, com o intuito de atender a uma demanda especifica dentro da Estação Ciência, até então não considerada: idosos de ambos os sexos e acima de 60 anos de idade. Ao participar do programa Universidade Aberta à Terceira Idade, o Núcleo teve a possibilidade de ampliar sua pesquisa e produção, agregando em sua atuação um novo e diferenciado público, que exigia atenção específica e inovações na forma de criar e transmitir informações sobre o fazer as artes cênicas.

Com foco no teatro e dança, o projeto Só com Experiência visou promover a autoestima, valorizar a história pessoal, o prazer do convívio em grupo, mas também dar oportunidade de praticar, compreender o fazer cênico, montar e apresentar espetáculos. A atividade foi efetiva em atrair participantes em número considerável, tanto que foi necessário 
formar três novos grupos em 2009, para poder atender à demanda gerada. As observações espontâneas, somadas aos registros em vídeo e depoimentos dos participantes, compreendendo esse período, evidenciaram ganhos comportamentais e funcionais em ambos os sexos, bem como a aceitação e envolvimento das propostas com relatado ganho de qualidade de vida.

Diante desses resultados, surgiu o interesse por parte de seus propositores e pesquisadores de explorar cientificamente a proposta, considerando a contribuição da literatura em arte e ciência. Assim, o estudo a seguir, focalizado sobre a observação, reflexão e mensuração de parâmetros funcionais e bioquímicos, busca evidenciar eventuais alterações físico-comportamentais a partir da prática e compreensão das relações intrínsecas ao fazer cênico.

A fim de aprimorar a pesquisa, foi acrescentado a esse estudo um segundo grupo, cuja prática foi baseada no resgate de memória, autobiográfico e literário, com o interesse de verificar se o oferecimento de outras modalidades de atividade teria ou não efeito similar sobre a população em análise.

Assim, esta pesquisa, inédita, busca avaliar a hipótese de que o envolvimento do individuo no treino corporal e intelectual constitui desafio motivador aos idosos no investimento por melhor qualidade de vida pela vivencia física, emocional e cognitiva, assim como subsidiar a elaboração de ações sociais, culturais, terapêuticas e preventivas a essa faixa etária.

\subsection{As artes cênicas, emoção e o idoso}

As artes cênicas, artes da cena ou seu equivalente em inglês - performing arts (Pavis, 2008) - são todas as formas de arte que têm como característica o desenvolvimento de sua ação realizada no palco, tradicional ou alternativo (praças, ruas etc.), e dirigida a um público restrito, como: ópera, dança, teatro, circo ou quaisquer intervenções artísticas. Sua ação é efêmera, presencial e exclusiva, pois, apesar da possibilidade de repetição da performance (peça, espetáculo, show, intervenção etc.), o seu resultado em cena será sempre inédito e único, permanecendo, enquanto forma e imagem do momento realizado, apenas na memória de quem executou ou assistiu. Atualmente, esse registro também se dá com equipamentos 
eletrônicos, porém, nesse caso, não se trata de artes cênicas, mas de vídeo, fotografia ou novas mídias. Outra característica marcante das artes cênicas é a utilização do corpo do artista como ferramenta fundamental para o entendimento e expressividade da sua linguagem. Corpo esse que se dá a conhecer por seus movimentos, gestos, falas, emoções, capacidades cognitivas e apresentação física.

"O corpo é o inconsciente visível”, disse Wilhelm Reich, e, ao lidar com esse corpo, histórias emocionais são apresentadas de forma direta. Assim, por mais que se queira criar subterfúgios, não há como escapar das verdades constituintes de suas formas, volumes, tensões, relaxamentos, reveladoras do grau de compreensão e conexão com a vida, porque as motivações geradas no meio interno são também os fatores geradores do comportamento do indivíduo. Por isso mesmo, "não há quem desconheça o fato das expressões espelharem os conflitos interiores" (Laban, 1978). Tal percepção sobre o outro e reconhecimento ou decodificação da expressividade desse corpo, que é de suma importância para a comunicação entre os seres humanos, e em especial para as artes cênicas, é, em síntese, "a compreensão daquela parte da vida interior do homem de onde se originam o movimento e a ação" (Laban, 1978), marcada acentuadamente por forças emocionais que originam a subjetividade do sujeito e o seu modus operandi de relação do seu corpo com o mundo. Segundo MerleauPonty (2006), “o sujeito que sou, concretamente tomado, é inseparável deste corpo aqui e deste mundo aqui". O que quer dizer que as ações e maneiras de se relacionar com o meio e o contexto social constituem em si mesmas a corporeidade e as dimensões humanas do ser no mundo. É o ato expressivo, o movimento corporal, que revela o comportamento do sujeito, reconhecido pelo outro, emergindo daí a significação do gesto, da comunicação e relação com o meio. Donde o sujeito é caracterizado e identificado por suas experiências e interação com o mundo por meio de processos cognitivos transformados em consciência (memória), resultando daí a inteireza do ser, do corpo inteiro. Diante disso, a emoção, situada na subjetividade do sujeito, tem papel crucial na constituição e preservação do ser, pois, se o corpo é expressão dessa subjetividade do indivíduo de se comunicar, ela faz parte do processo criativo-cognitivo de busca de relacionamento e sobrevivência no ambiente. A força impulsionadora da emoção, geradora de movimento (Damásio, 2011), irá estabelecer tanto a significação e comunicação do corpo pelo outro, como também a forma do sujeito ser no mundo. Portanto, se a emoção propicia a unidade interior, que coloca em movimento sua significação no exterior, não há como distinguir um gesto de uma soma de movimentos (Merleau-Ponty, 1975), ou seja, a emoção é a somatória de experiências de um corpo em 
ação. O que nos permite também dizer que "as emoções podem ser compreendidas como forças impulsionadoras, moldadas pela seleção natural, que nos motivam à ação, levando-nos a fazer uso de nossas capacidades cognitivas" (Worman \& Roder, 2004), sendo, portanto, fator preponderante para revelar a história corporal do indivíduo.

Pode-se, então, dessa forma, admitir que os corpos sejam histórias emocionais visíveis, mas se essas histórias resultaram ou foram moduladas pela emoção, é possível então admitir, também, que esse corpo ultrapassa a dimensão anatômica ao apresentar possibilidades de modulação permanente. Pois um corpo enquanto sujeito é um corpo vivo e propenso, inerentemente, a novas e marcantes experiências e ações criativo-cognitivas a todo instante. Para Rizzolatti (2005), um dos descobridores dos neurônios-espelho (NE), nossa sobrevivência depende da compreensão de atitudes, intenções e emoções das pessoas com as quais nos relacionamos. Nesse contexto, pode-se admitir como verdadeira a tese da força dos efeitos emocionais sobre o corpo, no caso aqui, da população idosa, que a princípio se caracteriza por possuir um repertório corporal definido e consequente subjetividade estabelecida, ser capaz, por meio de novas atitudes e interações, de se modular e adquirir novas formas e expressões corporais. É colocado que o trabalho com o corpo é sempre um ganho (Okimura, 2005), pois o corpo é da ordem da experiência, da vivência pela motricidade e da relação com o meio ambiente, que resulta em história e cultura e permite ao sujeito se apropriar da realidade. Desta forma, o trabalho com o corpo é um ganho pois é a partir dele que o conhecimento se processa e a consciência se manifesta para alcançar ou vivenciar novos estados motores, cognitivos e emocionais, possibilitando, assim, uma nova expressão e subjetividade.

Aos idosos é reservada, recorrentemente, no âmbito social, a ideia de pertencer a uma comunidade com a vida realizada, definida, de jornada concluída, o que resulta no oferecimento de poucas oportunidades para mover-se. A “decisão de mover-se", atitude fundamental para criar ambientes propícios à emoção e, por consequência, ao desenvolvimento e aperfeiçoamento das funções superiores e da própria consciência (Damásio, 2011), tem aí um impasse social muitas vezes aceito naturalmente pelo próprio indivíduo ou mesmo por algum sentimento de impotência. Sem a motivação e a ação dela resultante, o idoso fica sujeito a potencializar ainda mais as naturais alterações consubstanciadas em declínio motor, mental e social, prejudicando acentuadamente sua qualidade de vida, com risco de efeitos patológicos. No entanto, o indício para o gozo de um 
saudável envelhecimento está intrinsecamente relacionado ao bem-estar físico e mental do indivíduo, que no caso corresponde a ter oportunidades para fazer, realizar, sentir-se incluído e ter possibilidade de contribuir com a sociedade, num todo. Não se deve esquecer que o ser humano é um ser criativo em todas as etapas da vida, em geral, propenso a se desenvolver e atuar. A percepção do mundo é uma relação estritamente pessoal, que envolve outros indivíduos e o ambiente em que ele está inserido. Estar consciente dessa relação determina a forma como cada indivíduo envelhece e como vive a sua velhice (Brandão, 2009). Para tanto, o emprego de métodos formativos, tão pronunciadamente proclamados nos trabalhos de Steve Kelemann, Moshe Feldenkrais, Rudolf Laban e Steve Paxton, entre outros artistas e pesquisadores do corpo, contribuem de maneira significativa para a realização dessa tarefa. A formação educativa em artes cênicas, referência metodológica para a pesquisa em questão, favorece a vivência de estados emocionais marcantes, contribuindo sobremaneira para o equilíbrio das funções, habilidades e capacidades físicas e cerebrais, pois o "corpo", meio e fim da aprendizagem, se realiza na cena artística como um contínuo processo de transformações. Fenômenos da ordem da plasticidade neural, memória, emoção, atenção e invenção também estão presentes na educação do corpo que dança" (Ribeiro \& Teixeira, 2009). Argumentos também corroborados com achados do pesquisador Gazzaniga, que afirma: "O interesse em uma arte de performance leva a um estado de motivação que produz a atenção sustentada necessária para melhorar o desempenho e a atuação da atenção em geral, que leva à melhoria em outros domínios da cognição" (Gazzaniga, 2008); ou ainda, "A atuação em teatro parece induzir melhoria da memória por meio da aprendizagem de competências gerais para a manipulação semântica" (Gazzaniga, 2008).

Assim, o exposto induz a crer que as artes cênicas, com todas as suas implicações mentais, emocionais e físicas, são formas artísticas que requisitam o envolvimento do indivíduo na sua totalidade (Laban, 1978), contribuindo assim para a melhoria da qualidade de vida do praticante, neste caso a população idosa. Desta forma, as artes cênicas são uma linguagem que evidencia aspectos importantes da atuação do Sistema Nervoso (SN) sobre o seu fazer, o que está de acordo com a afirmação de Kandel (2010): “O cérebro é responsável não apenas por comportamentos motores relativamente simples, tais como correr e comer, mas também pelos atos complexos considerados a quintessência do ser humano, como pensar, falar, e criar obras de arte". 


\subsection{Sistema nervoso e as artes cênicas}

O sistema nervoso (SN), compreendido pelos sistema nervoso central (SNC), sistema nervoso periférico (SNP) e sistema neurovegetativo (SNV), é único (Guyton \& Hall, 2002) e complexo. É de sua natureza a responsabilidade pelo conjunto de ações, sentimentos e expressões que definem o ser humano enquanto realidade física e mental. Tem como características o controle e gerenciamento do meio interno das funções orgânicas, a percepção e consciência dos estímulos provenientes do meio externo e a integração desses meios para gerar respostas comportamentais. Além disso, ele também possui "múltiplos sistemas de neurônios-espelho, especializados em entender não apenas as ações dos outros, mas também realizar suas intenções, o significado social de seus comportamentos e de suas emoções" (Mendes et al., 2008 apud Blakeslee, 2006).

A complexidade do Sistema Nervoso, desde os tempos mais remotos, tem desafiado a curiosidade e a busca pelo conhecimento de suas funções. Na Grécia antiga, essa curiosidade também estava presente, tendo sido objeto de estudos e observações de grandes pensadores da época. Para Hipócrates (460-355 a.C.), considerado o "pai da medicina", o cérebro era o local onde se localizava a mente, sendo ele a sede da inteligência, o que está de acordo com as conclusões atuais; enquanto, para Aristóteles (384-322 a.C.), a mente tinha sua sede no coração, centro da vida, da sensação, do movimento e do calor (Bear, 2008), concepção que foi adotada no Ocidente, por imposição do Cristianismo, até quase duzentos anos após a Idade Média, quando o filósofo Descartes (1596-1650), em 1649, retomou a ideia de Hipócrates e localizou a mente novamente no cérebro. Porém, para ele, o corpo e a mente eram coisas distintas, separadas. Descartes considerou a glândula pineal como única estrutura física por onde a mente agia. Assim, o corpo se relacionava com os estados emocionais, e a mente (não material), com o comportamento racional (Descartes, 2000). Apesar de hoje ser contestada, essa teoria teve papel importante ao refutar o modelo vigente até então, o aristotélico, que durante tanto tempo fora intocável, assim como representar significativo avanço para a concepção localizacional das funções cerebrais, esta hoje não mais aceita como áreas estanques.

Os estudos sobre o cérebro iniciados no final do século XVIII por Franz Joseph Gall, (1758-1822), a princípio definidos por ele como "cranioscopia" e depois denominados "frenologia", incentivaram várias outras pesquisas da localização cerebral, como a de Pierre 
Flourens (1794-1867), que no início do século XIX investigou a localização de funções cerebrais (Bear, 2008) a partir da remoção cirúrgica de partes do cérebro de pombos e concluiu que as perdas funcionais das aves pesquisadas foram ocasionais, uma vez que após determinado período, houve recuperação espontânea (Kristensen et al, 2001). Outra importante pesquisa também do século XIX possibilitou a Pierre Paul Broca (1824-1880) afirmar que "Nous parlons avec l'hémisphère gauche" (Lent, 2010). Essa pesquisa, clássica, de Broca foi um marco para em neurociências e para atividade observacional de lesões cerebrais, como também a pesquisa não menos clássica na literatura neurocientífica, ocorrida com Phineas Gage (1848), operário americano da construção de estrada de ferro, que sofreu uma perfuração grave, que ocasionou perdas de estruturas do lobo órbito-frontal, resultando em sério comprometimento comportamental. Este caso foi estudado e documentado por John Martyn Harlow (1819-1907), entre 1848 e 1849, e revisitado por Hanna Damásio e colaboradores, em 1994. Denominado "O Caso Phineas Gage", contribuiu de forma significativa para a concepção localizacional das funções cerebrais (Damásio et al, 1994), hoje também questionada em favor de redes e circuitos neurais dedicados a determinadas funções (Nicolelis, 2011).

No entanto, estudos mais recentes têm revelado que essas áreas não são assim tão delimitadas, principalmente quando as observações sobre a ativação neuronal são vistas em imagens eletrônicas. Sob esta perspectiva, quando determinada função do cérebro é posta em atividade, ocorre o envolvimento de múltiplas outras áreas de maneira geral. Ramachandran (2007) discorre sobre a sinestesia, fenômeno em que há possibilidade de ocorrência de ativação simultânea, ou superposição de planos sensoriais distintos, cujos sintomas são mais observados em artistas. Segundo Ramachandran, essa condição possibilita o surgimento e estabelecimento de especificidades características do comportamento dos animais, em especial do ser humano, manifestada no pensamento metafórico e na criatividade do fazer arte, seja literatura, música ou teatro. Esse pensamento é também sustentado por outro neurocientista contemporâneo, Antônio Damásio, que compara o encéfalo a uma orquestra sinfônica e afirma que o produto final da consciência provém desses numerosos locais do cérebro ativados ao mesmo tempo, e não apenas de um local específico, semelhante à execução de uma sinfonia que resulta do trabalho integrado da orquestra (Damásio, 2011).

Estudos como o de Kandel (2003) defendem a localização das funções cerebrais, porém sem determinar de maneira absoluta os limites dessas áreas, e enfatizam que elas não estão 
isoladas da ação, interação e influência de outras múltiplas regiões. Há um núcleo, uma região responsável, sim, por determinada especialização, porém seu desempenho depende do envolvimento de boa parte do encéfalo, chegando até mesmo, em alguns casos, como o do uso da fala, à interação de quase sua totalidade (Lent, 2010).

De acordo com o exposto, é possível constatar que a busca por conhecer e desvendar o funcionamento do sistema nervoso sempre foi e continua sendo desafio à curiosidade, observação, estudo e produção científica. Esta última possibilitou conhecer e reconhecer no encéfalo as suas múltiplas e integradas funções processadoras de comportamentos, como, entre outras: movimento, memória, aprendizado, atenção e emoção. As quais são apresentadas abaixo com o intuito de enfatizar sua importância na geração de comportamentos humanos.

\subsubsection{Movimento}

A princípio, são destacados dois tipos de movimento: Voluntário (MV) e Involuntário (MI). O movimento voluntário está organizado no córtex cerebral. É nele que áreas motoras integram informações límbicas e sensoriais de forma geral, proprioceptivas, visuais e auditivas, para produzir os movimentos voluntários mais elaborados a partir de planejamento (Kandel, 2003). No entanto, o movimento também envolve os núcleos da base e o cerebelo nos processos de memória e execução, como evidenciam as lesões nessas áreas subcorticais, com prejuízos consideráveis sobre o ato voluntário.

Chama atenção a questão que busca identificar em que difere o ato voluntário do involuntário. A literatura indica que, ao contrário da resposta estereotipada ao estímulo do ato involuntário e automático dos reflexos, o movimento voluntário decorre essencialmente da capacidade organizacional e processual consciente da execução do movimento para atender a necessidades. Neste caso, sua realização é um ato diretamente ligado a uma sequência de percepção, e planejamento de resposta ao estímulo sugerido, ou a um impulso e ação interna do próprio corpo/cérebro. Ou seja, um mesmo estímulo pode ocasionar diferentes respostas e atitudes comportamentais. Outra particularidade do movimento voluntário é a sua possibilidade de aprimoramento pela experiência e aprendizado. Portanto, resultado de aspectos relacionados à memória, ao aprendizado, às reações racionais sobre as 
emoções, à consciência dos impulsos e objetivos trocados por programas e comandos de redes neurais.

No entanto, a "decisão de mover-se" não é facultativa apenas ao ato voluntário (Damásio, 2011). A eficácia e preservação do corpo dependem de verificação e controle dos processos do meio interno, executados por movimentos involuntários. Assim, o movimento involuntário torna-se um importante mecanismo através do qual podem resultar processos para a tomada de consciência e possíveis respostas com movimentos voluntários.

\subsubsection{Memória}

Segundo Kandel, "nós somos o que somos, em grande parte, devido ao que aprendemos e ao que lembramos" (Kandel, 2003). Levando em conta essa afirmação, é possível inferir que a consciência de fatos históricos da nossa vida, bem como a perspectiva vislumbrada no presente, decorrem de função cerebral superior comumente associada à emoção e à razão, denominada 'memória'. Ainda segundo ele, "a memória é essencial não apenas para a manutenção da identidade individual, mas também para transmitir a cultura e para a evolução e desenvolvimento das sociedades ao longo dos séculos" (Kandel, 2010). Dessas colocações resultam afirmações de que a memória é por excelência um comportamento de interações entre os genes e informações provenientes do ambiente (interno e externo). Desta forma, "o cérebro retém uma memória do que ocorreu durante dada interação, a qual inclui fundamentalmente o passado do indivíduo em questão, e até mesmo, muitas vezes, o passado de nossa espécie biológica e de nossa cultura” (Damásio, 2011).

As memórias correspondem a registros biológicos e a informações adquiridas e processadas pelo Sistema Nervoso, que as armazena com durações variáveis de acordo com a relevância para o indivíduo. São classificadas como memória explícita (declarativa), que ocorre em diferentes córtices associativos, e memória procedimental (Lundy-Ekman, 2004) ou implícita (não declarativa), essa, com processamento em circuitos perceptuais, motores e emocionais. Seu processo mnemônico "inclui a aquisição, retenção, esquecimento, consolidação e evocação" (Lent, 2010) pelos quais o evento memorável é codificado, decodificado, retido e, quando necessário, recuperado. Pesquisas têm evidenciado que a "memória corresponde ao processo pelo qual experiências anteriores propiciam alteração de comportamento" (Helene \& Xavier, 2003), promovido pela plasticidade do tecido nervoso, 
tanto na formação de novos contatos sinápticos como na facilitação de circuitos neurais, com produção de moléculas específicas. Interessante é observar que a consolidação da memória é altamente influenciada por sistemas moduladores, especialmente aqueles relacionados à emoção. Assim, emoções criam memórias e vice-versa, influenciando a personalidade do indivíduo. Por outro lado, pesquisas tanto científica quanto filosófica evidenciam que o ambiente com o qual interagimos é permeado por nossos pensamentos e crenças, sendo também uma extensão de nosso corpo, com influências recíprocas: “O Sistema Nervoso, em seu processo histórico de interação inicial com o ambiente, reage não apenas a estímulos, mas também às contingências espaciais e temporais entre os estímulos, e também destes com suas respostas, num processo de aprendizagem que leva à modificação no seu funcionamento...” (Helene \& Xavier, 2003).

\subsubsection{Aprendizado}

Tendo inscritos em nossos genes registros biológicos que remetem à evolução dos processos adaptativos dos animais sobre a Terra, resultando daí a memória primordial (Damásio, 2011), tão carregada de sentimentos, emoções, intuição e responsabilidade pela regulação da vida, o que definirá nossa relação com a natureza no presente pode ser entendido como “aprendizado". É dessa interação com o meio ambiente que a aquisição de eventos se dá e se configura como um ato sináptico de processamento de novas informações. A complexidade que a nós se apresenta em forma de mundo, desafiando nossas capacidades homeostáticas e intelectuais, nos solicita e depende da capacidade de aprender e de como articular essas novas informações com a evocação de lembranças, que resultarão em ações comportamentais que caracterizarão o indivíduo. A aprendizagem é o processo de aquisição das informações que vão ser armazenadas (memória) e evocadas no momento adequado. Essa relação, aprendizagem e evocação, é a base para a criatividade e imaginação, pois ela permite elaborar pensamentos e planejar ações futuras. Estamos sempre nos defrontando com o inusitado e a aprendizagem, articulada com a memória, é o meio pelo qual se permite reconhecer ou mesmo interagir com esse fato novo no segundo momento de contato. Os parâmetros para distinguir aprendizado de memória são sutis, mas eles existem e se diferenciam um do outro. Enquanto a memória tem "a capacidade de adquirir e armazenar informações simples, como detalhes cotidianos da vida, e tão complexas, como o conhecimento abstrato da geografia, da álgebra" (Kandel, 2010), o aprendizado é a apreensão 
de conhecimento (memória) que pode ser utilizado na produção de algo novo para e pelo individuo.

O aprendizado, segundo Kandel, "pode depender de uma combinação de várias formas elementares de plasticidade sináptica, tornando-a assim mais complexa, tal qual um alfabeto é utilizado para formar as palavras" (Kandel, 2010). As bases gerais dos circuitos neuronais geradores do aprendizado são ainda objeto de estudo. No entanto, há certeza do envolvimento das áreas associativas pré-frontal, parietal, occipital, temporal e límbica, incluindo a formação hipocampal, no planejamento do aprendizado. As duas primeiras regiões indicadas, préfrontal e parietal, onde se situam os neurônios espelhos, são conhecidas como importantes áreas para a imitação humana. Nesses circuitos, o corpo caloso representa importante mediador e catalisador das especificidades correspondentes à aprendizagem, entre os dois hemisférios cerebrais.

\subsubsection{Atenção}

"The taking possession by the mind, in clear and vivid form, of one out of what seems several simultaneously possible objects or trains of thought. Focalization, concentration of consciousness are of its essence. It implies withdrawal from some things in order to deal effectively with others".

William James, Principles of Psychology, 1860.

A atenção se caracteriza como um processo mental dos mais elevados e evidencia quão flexível é o encéfalo humano. Os circuitos que formam a atenção no cérebro selecionam o que lhe é mais interessante e importante para o momento, descartando completamente aquilo que não foi focalizado. Isso se deve à incapacidade, apesar dos seus bilhões de neurônios, de assimilar e tornar conscientes todas as informações que chegam do ambiente e ou do próprio corpo, simultaneamente. "Tudo que é percebido pela mente é sentido pelo corpo de algum modo, mas nem tudo que é sentido pelo corpo alcança a percepção" (Lent, 2010). O que resulta em mecanismos otimizados de percepção, associando "as informações sensórias à memória e à cognição" (Lent, 2010). É esse padrão de processamento neural que contribui de forma decisiva para que sejam formulados conceitos e contextualizações do mundo e definição do próprio ser, tanto psicológico quanto comportamental. O estado de alerta, ou atencional, decorre da focalização da consciência, envolvendo estruturas perceptuais do 
encéfalo responsáveis por selecionar determinada tarefa, ou percepto principal, e relegando as demais a segundo plano. Para Bear (2008), a atenção desempenha papel-chave na seleção da informação que deve ser recebida pelas limitadas possibilidades de pensamento do encéfalo, decorrendo daí forte relação entre a atenção e os mecanismos da consciência. Damásio, em seus estudos sobre consciência, correlaciona o mapeamento de espaços e estruturas internas e externas do indivíduo com alto grau de exigência atencional do encéfalo, incluindo não só seus níveis superiores, como também todo o sistema sensorial: "As sensações e emoções são percepções compostas daquilo que ocorre em nosso corpo e em nossa mente" (Damásio, 2011). Bear (2008) afirma que ainda que se possa conceber a atenção como um processo estritamente cognitivo de alto nível, experimentos demonstram que os efeitos da atenção podem ser observados em numerosas áreas sensoriais, estendendo-se desde a área VI até áreas corticais visuais, nos lobos parietal e temporal.

O fato é que a atenção facilita a detecção daquilo que interessa ao individuo em determinado momento, podendo ser treinada e aperfeiçoada, para benefício qualitativo e quantitativo sobre uma atividade específica, abstrata ou física (Gazzaniga, 2008). Como a atenção é um processo que transforma estímulos sensórios em percepção, focaliza a consciência (sobre o assunto, tema ou objeto selecionado, mas também sobre o contexto e ambiente propostos), atua no processo de estabelecimento de memória e cria condições adequadas ao aprendizado, que sugere conceber conceitos, contextualizações e ações comportamentais mais adequados para interagir com o mundo.

\subsubsection{Emoções}

Por que, ao se dizer alguma coisa a alguém, se evoca "algo a mais" que apenas sons articuláveis transformados em linguagem, pois sem esse "algo a mais" o que dizemos não seria compreensível? O que faz com que o individuo seja resultado da motivação de suas experiências?

Diante de tais questionamentos, cabe também perguntar, em se tratando de fenômeno psicológico: há alguma coisa mais importante para o homem do que suas emoções? Seja em estado normal, patológico, de vigília ou sono, "qualquer que seja a forma de pensamento representações afetivas, imaginação, fantasia ou pensamento lógico -, ele tem a sua base numa emoção" (Vigotsky, 1987). O que nos leva a refletir que qualquer resposta 
comportamental do indivíduo "é gerada por motivação, isto é, por desejos e necessidades" (Vigotsky, 1987) internas.

Emoções são sentimentos que experimentamos em um momento ou outro (Bear, 2008). Sua importância é tão significativa que não é possível nos imaginarmos sem elas ou sem compreendê-las no outro. Tratados robustos sobre a emoção têm sido produzidos desde os estudos de Darwin (1809-1882) no livro “A expressão das emoções nos animais e no homem” (1872, 2000), que relata observações e reflexões sobre as emoções como geradoras de comunicação também entre os animais, sugerindo que algumas de nossas expressões são resquícios herdados de antepassados da escala filogenética, comuns tanto ao homem quanto a outros animais. Já Wiliam James (1842-1910) e Carl Georg Lange (1834-1900), que articularam suas propostas no que ficou conhecido como "teoria de James-Lange" (Bear, 2008), argumentam que a experiência emocional subjetiva seria precedida às manifestações fisiológicas e comportamentais (Antonio et al, 2008) assim o estado motivacional, alegre, é resultado do estado motivado, sorrir. Porém, em 1927, essa teoria foi duramente contestada e reformulada por dois norte-americanos, Walter Cannon (1871-1945) e Phillip Bard (18981977). Conhecida como "teoria de Cannon-Bard", afirma que a experiência emocional podia ocorrer independentemente de uma expressão emocional (Bear, 2008), ou seja, que o SNC causa tanto a experiência subjetiva quanto as manifestações fisiológicas e comportamentais (Antonio et al, 2008). Apesar de essas propostas estarem sujeitas a críticas e reformulações, elas abriram caminho para algumas das teorias mais atuais, centradas na ideia adaptativa do ser humano, que revisitam os estudos de Darwin, colocarem tanto a emoção como a cognição como aspectos de uma mesma unidade, e não exemplos distintos de causalidade comportamental (Antonio et al, 2008). Segundo Damásio, "o tema do cérebro é o corpo", entendendo esse cérebro como o resultado de processos conscientes oriundos da motivação (emoção) e respostas comportamentais (cognição) adaptativas e preservacionistas do tema em questão, o corpo (Damásio, 2011). Em artigo de revisão sobre a psicologia evolucionista, com foco nas emoções como solução para os problemas adaptativos, Antonio e colaboradores argumentam que o cérebro foi projetado pela evolução para usar informações dirigidas do ambiente e do próprio organismo, a fim de regular funcionalmente o comportamento e o próprio corpo, e isto reúne aspectos cognitivos e emocionais (Antonio et al, 2008). O que vai ao encontro da definição de emoções por Damásio, que diz que "emoções são programas de ações complexos e em grande medida automatizados, engendrados pela evolução. As ações são complementadas por um programa cognitivo que inclui certas ideias e modos de 
cognição, mas o mundo das emoções é, sobretudo, feito de ações executadas no nosso corpo, desde expressões faciais e posturas até mudanças nas vísceras e no meio interno" (Damásio, 2011). De onde se origina e dá forma a sua hipótese sobre o marcador somático, que, em síntese, designa as tendências do comportamento humano às atividades somáticas (Damásio et al, 1991). Resumindo, emoção e cognição são processos permanentes de geração de ações mentais.

Assim, pelo exposto, sugere-se que a emoção tem valor adaptativo significativo para o ser humano, sendo o fruto de intensa plasticidade neural, algo tão particular e tão importante do SNC, considerando seus aspectos filo e ontogenéticos.

Diante do colocado e destacando aspectos da anatomia e da evolução filogenética do sistema nervoso, pode-se dizer que ele está configurado tendo as regiões medulares - a medula oblonga, a ponte e o mesencéfalo - como reguladoras das funções responsáveis pela vida (homeostase); ficando reservadas ao cérebro (diencéfalo e telencéfalo) as tarefas mais complexas dos comportamentos como a percepção, a representação, o raciocínio abstrato, a linguagem, o planejamento e a execução voluntária de ações.

"A linguagem tem como função primordial a comunicação" (Besson \& Schon 2001, 2006). A comunicação entre os animais é uma das marcas significativas da complexidade que envolve simultaneamente múltiplas áreas do Sistema Nervoso, com ativação especial de órgãos e funções localizadas no encéfalo, principalmente no córtex cerebral, como aquelas responsáveis pela fala e compreensão da linguagem, áreas 40 e 44 de Brodmann, respectivamente, nos hemisférios dominantes. Essas áreas se inter-relacionam e dão, aos signos característicos das linguagens, entendimento de conteúdo e expressão comportamental, quando em associação com áreas associativas. Uma ampla literatura referente a esse tema nos informa que, no hemisfério direito, se localizam as funções ligadas mais à percepção espacial quantitativa, artística; do reconhecimento geral de faces e figuras, do abstrato e das emoções contidas na linguagem. Essa última, conhecida como "prosódia", de importância fundamental para a comunicação entre as pessoas, sendo ela especificidade do ser humano. Ao hemisfério esquerdo são atribuídas as funções de ordenação temporal (sequencialização), reconhecimento de detalhes, julgamento analítico, identificação específica, leitura, escrita, fala e linguagem (Lent, 2010). 
Comum entre os animais, a comunicação no caso do ser humano é de uma complexidade tal que apresenta comportamentos exclusivos da sua espécie, como a fala, a leitura e a escrita. Desta forma, a comunicação entre seres humanos se distingue consideravelmente da comunicação de outros animais não só por suas formas de expressão e identificação de signos, mas principalmente pelo que produz: cultura, ciência, história, artes.

As artes cênicas como forma de linguagem artística são exemplo do grau de complexidade a que chegou a comunicação humana, exigindo a atuação de não apenas algumas poucas áreas do encéfalo, mas, senão, da totalidade dele, mais do que imaginamos: mais da metade do córtex "é ocupado por áreas de associação, as quais coordenam eventos originários dos centros motores e sensoriais. Essas áreas de associação - pré-frontal, parietal, occipital, temporal, límbica - estão envolvidas no planejamento do comportamento cognitivo, no pensamento, no sentimento, na percepção, na fala, na aprendizagem, na memória, na emoção e nos movimentos elaborados" (Kandel 2003). Há estudos hoje que difundem a atuação do cérebro estando envolvido como um todo na execução de tarefas, mas com prioridade para circuitos específicos, sem deixar fazer com que os outros circuitos deixem de atuar também (Nicolelis, 2011). A complexidade de criação e execução das artes cênicas, contendo, entre outras ações, planejamento, emoção, emissão de voz, visualização, audição, movimento do corpo pelo espaço e em cumplicidade com o outro, atenção, consciência, entre outras funções e modalidades do comportamento, faz com que o Sistema Nervoso seja exigido em sua potencialidade. Assim, por meio da ativação simultânea de seus diversos núcleos e funções, o Sistema Nervoso atua no fazer e reconhecer movimentos e expressões característicos das artes cênicas.

O treinamento e execução das artes cênicas promovem ampla gama de possibilidades e interações neurofisiológicas, incluindo liberações de substâncias neuroativas, sejam neurotransmissores, moduladores ou hormônios, favorecendo assim o recrutamento de ações em favor do equilíbrio orgânico e expressão comportamental. 


\subsection{Arte, ciência e saúde}

"A arte sempre foi e será um recurso essencial para o desenvolvimento das relações interpessoais, para a comunicação eficiente nos diversos ambientes profissionais e no convívio social, pois ela estimula a sensibilidade e torna as diferenças plausíveis de encantamento e prazer espiritual. Podemos dizer que as expressões artísticas funcionam como fonte de "insight", estimulando a criatividade, o respeito mútuo, o prazer de reconhecer as diferenças ou um "espelho", no qual as pessoas se enxergam, se identificam e se veem. E quando combinada a conteúdos científicos no seu fazer e entender, ocorre simbiose perfeita: o participante é tocado por "uma varinha mágica": pergunta, discorda, dialoga, quer saber mais... A grande aventura humana da busca pelo conhecimento tem aí lugar: racionalidade e sensibilidade dão-se as mãos, tornando a viagem prazerosa e inesquecivel” (Matos; Melo, 2003).

A população de adultos com mais de 60 anos de idade deve crescer continuamente ao longo deste século - de modo mais acelerado em sua primeira metade. Segundo o Instituto Brasileiro de Geografia e Estatística - IBGE (2002), é fenômeno mundial, sem precedentes. Em “1950, eram cerca de 204 milhões de idosos no mundo, já em 1998, quase cinco décadas depois, este contingente alcançava 579 milhões de pessoas". O IBGE ainda alerta: "As projeções indicam que, em 2050, a população idosa será de 1.900 milhões de pessoas". No Brasil, os dados estatísticos refletem a tendência mundial com considerável crescimento populacional de idosos em todo o seu território. A projeção é que, em 2025, seremos a sexta população de idosos no mundo, com 32 milhões de pessoas acima de 60 anos de idade. Segundo o Ministério da Saúde (2007), essa marca tem como geradores a queda de natalidade e mortalidade, aliadas ao aumento da expectativa de vida. Este crescimento acelerado, se não acompanhado de políticas sociais adequadas, acarreta consequências indesejáveis, como o aumento significativo de doenças crônicas, necessidade de maiores cuidados e de acompanhamento, assim como custos elevados ao sistema de saúde pública. Nesse panorama, é importante oferecer alternativas à população dessa faixa etária, a fim de que possa usufruílas com a melhor percepção de qualidade de vida possível. 
O envelhecer, segundo Velasco (2005):

“... a velhice é uma triste coleção de perdas e limitações, pois diminuem a visão e a audição, a força e a precisão manuais, a robustez na execução de tarefas, a memória, a imaginação, a criatividade, a adaptação, a atenção, a energia, a iniciativa e a sociabilidade... O idoso, quando consciente de sua realidade, não pode ter projetos, não se permite pensar num depois, já que o depois da velhice é a morte”.

Esse quadro descrito pela pesquisadora pode nos influenciar a acreditarmos em dois grandes erros popularmente disseminados, quais sejam: 1) todas as alterações que ocorrem com a pessoa idosa são decorrentes do processo de envelhecimento natural (MS, 2007) e 2) o envelhecimento natural é uma doença. Em sua publicação de 2007, o Ministério da Saúde adverte que o envelhecimento seja "compreendido como um processo natural, de diminuição progressiva da reserva funcional dos indivíduos - senescência -, sendo que, dependendo das condições do meio, pode ocasionar uma: senilidade", situação que requer assistência. E ainda enfatiza: "Seus efeitos podem ser minimizados pela assimilação de um estilo de vida mais ativo”. Para a Organização Mundial de Saúde (2005), envelhecimento ativo é definido como “otimização das oportunidades de saúde, participação e segurança, com o objetivo de melhorar a qualidade de vida à medida que as pessoas ficam mais velhas". Acreditando que o processo de envelhecimento é uma jornada e não um fim, Teixeira e Neri (2008) dizem que o "fundamental para se ter um envelhecimento saudável é aceitar as mudanças fisiológicas decorrentes desse período de vida da pessoa". Afirmação igual é feita também por Phelan e colaboradores em artigo de 2007, que ainda acrescenta ao envelhecimento bem sucedido o fato de ser ele "multidimensional e abrangendo a saúde física, funcional, psicológica e social". A vida do ser humano, assim como de todo organismo multicelular, é pautada por sua finitude e consequentes alterações fisiológicas durante o período compreendido entre o nascer e o morrer. Não dá para dizer exatamente quando o processo de envelhecimento é iniciado, no entanto, o declínio das capacidades envolvendo alterações neurobiológicas, funcionais e químicas, comprometendo assim, a força, equilíbrio, flexibilidade, agilidade, motricidade (Meireles et al., 2010), acrescentado a isso sintomas de deficiências psicológicas e sensoriais (Cardoso et al., 2008), fica mais evidente quando o indivíduo atinge a fase mais madura do ser, após os 60 anos de idade, refletido na aparência, no comportamento e nas relações sociais. É justamente sobre essa fase da vida, em que alterações fisiológicas, psicológicas e sociais se intensificam, que recaem as propostas da OMS de uma política de envelhecimento ativo, tendo como pressuposto que "envelhecer faz parte de uma construção coletiva e que deve ser 
facilitada pelas políticas públicas e por oportunidades de acesso à saúde ao longo do curso da vida" (Silva et al., 2010), por meio de medidas preventivas que possam favorecer a manter o idoso em condições funcionais e cognitivas propícias a sua autonomia e independência.

Dentre as medidas e fatores possíveis, a prática de atividades físicas é considerada por muitos pesquisadores como essencial para obtenção de boa saúde pelo idoso. Segundo Lambertucci et al. (2005), no processo de envelhecimento saudável é indispensável a prática física regular, pois ela propiciará melhoras significativas na "musculatura esquelética dos idosos - hipertrofia muscular, aumento da força e adaptações celulares e funcionais, por exemplo". Santos et al. (2009), reafirmando essa mesma ideia, enfatiza sua ação na prevenção tanto de distúrbios emocionais quanto de desordens somáticas, colocando-a como uma “intervenção com potencial para reduzir a associação entre a depressão e a deterioração cognitiva dos idosos, produzindo efeitos positivos no seu humor”. Em artigo de revisão sobre atividade física e o processo de envelhecimento do Sistema Nervoso, Cardoso e colaboradores (2007) confirmam a importância da atividade física na saúde do Sistema Nervoso, nas funções cognitivas, e sua influência sobre aspectos da plasticidade neural. Estudos dos benefícios da atividade física evidenciam alterações fisiológicas consideráveis no corpo em movimento durante práticas dirigidas, tais como fluxo sanguíneo e oxigenação mais efetivos, dinâmicos, que melhoram a performance em geral, de forma que as atividades físicas (Okimura, 2005), e mesmo intelectuais, melhorem o funcionamento orgânico e nervoso em especial, com liberação de endorfinas, fatores tróficos e moléculas relacionadas ao bem-estar, facilitando a aquisição de novas habilidades.

“As artes cênicas, por ser forma de comunicação ao vivo" (Chacra, 2010), de realização coletiva e exclusivamente humana, podem constituir fator de motivação em potencial para o estabelecimento de novas memórias e aprendizagem nas várias faixas etárias. Por outro lado, muitos dos jogos realizados (entre ator e corpo, entre atores e atores, e entre atores e ambiente) se dão a partir da imitação, que é um processo de suma importância no desenvolvimento humano, na aprendizagem motora, na comunicação e nas habilidades sociais. No caso da população de idosos, estudos evidenciam que práticas caracterizadas por exercícios físicos e intelectuais são elementos fundamentais de socialização, onde os processos corporais e cognitivos atuam e promovem autoestima, autodeterminação, autonomia, autoconhecimento, identidade pessoal, prazer do convívio em grupo e o resgate da história pessoal. 
Assim, por ser o corpo o elemento fundamental da existência, prática e interação dessa linguagem e comunicação, é nele que devem ser identificados os mecanismos de percepção do mundo e suas consequentes respostas comportamentais. Neste sentido, reside a importância de gerar condições para explorar os diversos canais sensoriais de forma contínua, para expandir ou resgatar sua sensibilidade, assim como desenvolver recursos e habilidades corporais para promover desbloqueios emocionais, ajustes e reajustes de respostas motoras adequadas, a fim de estimular os processos de criação artística, a cognição, potencializando a interação desse corpo com o ambiente. São esses fatores desenvolvidos no âmbito do fazer artístico que potencializam o praticante a lidar consigo mesmo, com o outro, bem como a aprender, compreender e atuar no mundo e consigo mesmo.

Para tanto, neste estudo destacamos algumas importantes contribuições para o entendimento da estrutura, forma, função e expressão do corpo, como a do bailarino e coreógrafo Rudolf Laban, célebre por ter desenvolvido uma codificação para o movimento humano capaz de registrar seus vários tipos de expressão: na arte, no trabalho ou no cotidiano. Esse trabalho, denominado por ele de "Kinetography Laban", e conhecido nos Estados Unidos da América como "Labanotation", está baseado em estudos fisiológicos e psíquicos que levam o homem a se movimentar. Sua determinação em elucidar a singularidade do movimento humano foi exaustiva e constitui ainda hoje elemento para observação do movimento consciente (daí o seu uso nessa pesquisa), possibilitando conhecer de onde se originam o movimento e a ação (Laban, 1978). A utilização de seus estudos e resultados, a princípio reservados à dança, foi e ainda é uma contribuição considerável para o entendimento do movimento corporal no teatro. "O movimento humano, com todas as suas implicações mentais, emocionais e físicas, é o denominador comum à arte dinâmica do teatro" (Laban, 1978).

Outro importante estudioso do conhecimento e consciência do movimento humano, com atenção especial relacionada às suas possibilidades de uso nas artes cênicas, Moshe Feldenkrais, foi requisitado para o estudo e aplicação de exercícios referidos em seu "Método Feldenkrais". Esse método, por ser um sistema de educação somática, enfatiza a busca por movimentos mais precisos e eficazes. Segundo Feldenkrais, "a capacidade do ser humano aprender é infinita, única entre os animais, por ser seu cérebro capaz de mudar padrões estabelecidos e criar respostas mais simples e eficazes", o que requer, entretanto, atuação 
dirigida e motivação (Feldenkrais, 1977). Seu método é realizado por meio de experiências físicas que pretendem, pela repetição e pelo re-treinamento, substituir um padrão de movimento (ou imagem corporal) não adequado por outro mais próximo do ideal, confortável e saudável. Ele se baseou em estudos do sistema nervoso para explorar em seu trabalho a plasticidade neural. Entre os vários objetivos que ele propõe, a partir do reconhecimento e uso do potencial oculto na experiência corporal, está a melhora da postura e o aprimoramento dos movimentos expressivos e instrumentais. Com exercícios orientados para a passagem de estados de tensão a estados de tranquilidade, que resultarão na aquisição de um novo repertório de ação e na mudança de atitude, o método se coloca como um facilitador de transformação da qualidade das relações pessoais e profissionais.

Em continuidade nessa linha de observação e trabalho corporal e sua aplicação nas artes cênicas, a pesquisa recorre também às práticas e contribuições de Klauss Vianna, coreógrafo de fundamental importância para o entendimento do movimento corporal, tanto na dança como no teatro, durante toda a segunda metade do século XX no Brasil. Para ele, não bastava ao profissional do corpo, ator e bailarino, técnica ou virtuosismo, "mas permear todo esse contexto do movimento por uma ideia criadora" (Vianna, 2005). Sua permanente observação sobre o corpo o levou a considerar como uma verdadeira criação artística, em se tratando das artes cênicas, aquela em que o praticante busca o autoconhecimento e uma interação maior com o mundo, via inspiração e liberdade de expressão. Toda a sua postura como criador e pesquisador foi de "estimular contribuições individuais", enfatizando a consciência das nossas limitações para utilizá-las como possibilidades criativas. Seu trabalho e percepção sobre o movimento corporal é considerado pioneiro, bem como a sua aplicação nas artes cênicas no Brasil. Embora não exista registro ou codificação desse trabalho ou técnica, como outrora fizera Rudolf Laban, ele foi desenvolvido diretamente entre bailarinos e atores, e pode ser entendido como "um método de educação somática" (Neves, 2008). Klauss Vianna foi um artista experimental e intuitivo, que gostava de correr riscos, de arriscar por caminhos nunca antes percorridos para a expressão corporal, conseguindo, por meio de sua aguçada percepção sobre arte do movimento, conceber uma forma peculiar e autoral de ensino "afinado com a filosofia dos grandes artistas da dança contemporânea, como Pina Bausch e Kazuo Ohno" (Vianna, 2005). Neste estudo, seu trabalho foi constantemente empregado, desde a "chegada" ao teatro, com o corpo deitado no chão para sentir-se presente no ambiente e desvencilhar-se do que deixara para trás (Vianna, 2005); com os frequentes estudos e atenção sobre a musculatura, quando em movimento voluntário; nas referências à gravidade e peso dos corpos 
e sua sensibilização por meio de toques sobre toda a sua superfície, buscando assim tornar conhecidas e conscientes todas as suas partes. A contínua exploração do corpo e do espaço de forma lúdica resultou em constatações óbvias, porém surpreendentes aos praticantes, que geraram ou ampliaram a percepção de si e das sutilezas geradas com os exercícios daquele momento.

Com o propósito de identificar conflitos emocionais e sua possível vinculação com tensões e pontos de rigidez presentes em áreas específicas no corpo, assim como possíveis formas de modificar esses quadros, se recorreu aos estudos psicossomáticos desenvolvidos inicialmente por Wilhelm Reich e depois por Alexander Lowen e Stanley Keleman (Dychtwald, 1984). Lowen é o criador da Bioenergética, conceito que se apoia na proposição de que cada ser é o seu corpo (Lowen, 1982) e que inclui exercícios psicofísicos, ou sejam, exercícios físicos com impacto na parte psicológica, para proporcionar ao indivíduo reencontrar-se com seu próprio corpo. Seu trabalho possibilita a estruturação corpo-mente, que induz à autodescoberta e à compreensão de características do caráter humano, ou o próprio caráter em geral, em termos de corpo humano. Visto dessa forma, Lowen ampliou o trabalho de Reich, incluindo a vitalidade do organismo e sua qualidade de vida. Lowen chama atenção para os aspectos relacionados à linguagem do corpo, que segundo ele possui duas partes: "uma lida com os sinais e expressões do corpo, que transmitem informações sobre o indivíduo, e a segunda lida com as expressões verbais, que por seu significado se referem às funções corporais" (Lowen, 1982). A comunicação corporal é não verbal e seu entendimento está justamente em como o corpo se apresenta em termos de movimentos de expansão ou contração. Dificilmente o corpo irá se colocar em informação sem trazer consigo a história emocional contida nessa expressão. Se isso acontecer, o próprio corpo revela o quão ficou aquém do significado real de seus propósitos de comunicação eficiente. É isso que Lowen busca dar a entender quando se refere à primeira parte dos seus estudos sobre a linguagem corporal e afirma que "o corpo não mente". Mesmo que queiramos passar outra versão de determinada informação, a compreensão sobre os aspectos expressivos para o outro se mostrará vazia de sentimentos e com posturas artificiais, denunciando assim tensões musculares que resultam em comunicação não sincera - aceita, às vezes, por implicações sociais, por estar sob pressão física ou psicológica. Já na segunda parte, ressalta que o foco é quanto ao significado de dada expressão, que reflete o estado funcional do corpo em relação aos estímulos que lhe são propiciados. Expressões como "apoiar-se sobre seus próprios pés", "cabeça dura", "mão fechada", entre outras, nos remetem à atenção sobre o grau de equilíbrio, 
inflexibilidade e avareza, respectivamente. Podemos afirmar que a primeira está intrinsecamente relacionada ao que, em neurociências denominamos de prosódia, modalidade perceptiva sobre a intencionalidade e emoções contidas na comunicação entre os seres humanos, pois apenas estes a possuem. Enquanto que a segunda diz respeito a questões culturais e sociais. Esses aspectos da linguagem corporal esboçados por Lowen revelam leituras corporais do estado psicossomático do corpo em exposição, em movimento, fornecendo observações plausíveis sobre o quanto músculos e órgãos estão em sintonia com suas qualidades originais de emissão e compreensão da linguagem. Seus enunciados e pressupostos, enfatizados tanto no nível corporal como verbal, foram muito úteis, principalmente aqueles observados durante a execução do movimento consciente ou mesmo quando o movimento foi espontâneo, dando expressão emocional à história pessoal dos participantes do projeto. Os estudos de Lowen aplicados nessa pesquisa foram muito significativos para o entendimento e desenvolvimento das expressões em cena com o grupo de pesquisa, pois, para as artes cênicas, é fundamental dar sentido (ou verdade) ao movimento em cena, sob suas diversas formas: voz, gestos, canto etc., assim como possuir um estado orgânico capaz de assimilar e produzir reações metabólicas adequadas às respostas requisitadas naquele momento, e isso só é possível se o corpo se apresentar sem medo, aberto, seguro e permitir participar do que realmente está sendo oferecido em cena, sem subterfúgios ou disfarces.

Já os estudos de Keleman (1992) adicionaram importantes observações sobre os aspectos emocionais presentes na forma corporal apresentada pelo individuo. Keleman, em seus pressupostos, correlaciona estrutura e forma corporal do indivíduo com o que lhe foi herdado em forma genética e na aquisição pessoal de sua história emocional. Segundo ele, é dessa interação dinâmica e constante que a forma característica de cada pessoa se evidenciará e constituirá as ocorrências das conexões entre a anatomia e os sentimentos. "A vida produz formas" é o seu mote para fluir sobre elaborações teóricas e observações práticas em que a forma somática do individuo é reflexo da sua história genética, social e pessoal. Assim, para ele, a forma corporal do individuo é o resultado de sentimentos, pensamentos e experiências vivenciadas pelos indivíduos. A aplicação de seus estudos nesta pesquisa buscou identificar sua afirmação quando diz que a vida em todos os níveis é um processo em permanente construção e desconstrução, em que, conforme afirma Regina Favre, na introdução ao livro de Keleman, Anatomia emocional, (1992), “o pulsátil, o gravitacional, o aéreo, o emocional, o afetivo e o mental geram as infinitas modulações e tonalidades do sentimento de estar vivo". 
O propósito de indicar neste estudo os autores acima é evidenciar a preocupação com o que é essencial tanto para as artes cênicas como para os estudos neurocientíficos: o corpo e suas expressões físicas e emocionais.

Para as artes cênicas, o corpo é a ferramenta, a base que o artista tem para imprimir sua vocação e trabalho e sem o qual é impossível realizar a obra que caracteriza essa linguagem. Diante deste fato inexorável, o artista precisa se conhecer e se conscientizar de suas possibilidades corporais, pois só assim poderá corresponder à prontidão necessária para a interação cênica e os desafios criativos corporais que tanto o teatro, o circo ou dança requerem. Segundo explicitado no Dicionário de Teatro (Pavis, 2008), "os encenadores contemporâneos fizeram uma opção pelo uso do espaço cênico libertos das palavras ou pelo menos assim se verifica no teatro experimental, com a tendência do corpo material predominando na encenação". Esse corpo proporciona "a nova linguagem física, baseada em signos e não mais em palavras" (Artaud, 2006).

Diante deste olhar contemporâneo sobre o corpo na encenação, foram agregadas ao presente estudo as contribuições teóricas de criadores como Peter Brook e Antonin Artaud, que valorizam a tendência de considerar o corpo como organismo vivo ou instrumento do ator: "Os exercícios do ator consistem em produzir emoções a partir do domínio e do manejo do corpo" (Pavis, 2008).

Para Peter Brook, o corpo do ator deve ser organismo puro, sem vícios ou vicissitudes adquiridas socialmente, e que não são nada mais que obstáculos distanciadores entre o ator e seu corpo natural. Esse corpo, trabalhado com obstinação, adquirirá técnica suficiente para ser apenas um receptáculo, permitindo de maneira fluida a ação do personagem. É na preparação desse corpo como espaço vazio (Brook, 1970) que se concentra o trabalho do ator, naquilo que não deve "objetivar o como fazer, mas o como permitir".

Antonin Artaud é ainda hoje um dos mais polêmicos criadores do teatro. Sua vida e obra se confundem e nos dão a dimensão exata de sua obsessão por uma arte visceral e orgânica, onde a vida é celebrada em ritual sagrado. Acreditando numa perspectiva da arte como terapia da alma, ele afirma que "romper a linguagem para tocar na vida é fazer ou refazer o teatro; e o importante é não acreditar que esse ato deva permanecer sagrado, isto é, reservado. O 
importante é crer que não é qualquer pessoa que pode fazê-lo, e que para isso é preciso uma preparação" (Artaud, 2006). Essa visão iniciática de um teatro total (Berthold, 2010) e de respeito pela vida, holisticamente falando, é um aspecto importante à integração do corpo, mente, história e sentimentos quando se trabalha com qualquer grupo artístico, inclusive aqueles compostos por idosos.

E como se deu o vínculo entre essas práticas e teorias do corpo nas artes cênicas e neurociências? O corpo, vivo, está em constante interação consigo mesmo e com o meio que o cerca. Canais sensoriais e sistemas orgânicos corporais são os meios que intermediam esse processo. A entrada de sensações de diversas fontes (eletromagnética, mecânica, química) é transduzida em impulsos elétricos e decodificados para ter o seu feedback mais adequado, voluntário ou automático, e servem para estabelecer processos de atenção, memória e aprendizagem (bem como várias outras funções cerebrais) por meio de impulsos motivacionais, que irão definir, por suas ações mentais os estados comportamentais no indivíduo. Este estudo buscou evidenciar e estimular esses canais de entrada (sensações) e saída (respostas comportamentais) do Sistema Nervoso e o grau de plasticidade observável conseguido em relação ao equilíbrio do organismo, à memória, ao desenvolvimento cognitivo, emocional e dos aspectos do sistema motor, como postura, equilíbrio, qualidade na execução da marcha e da articulação simultânea das várias partes do corpo, em um grupo de idosos praticante das artes cênicas, tendo como suporte a literatura em ciência, arte e saúde. 


\section{JUSTIFICATIVA}

“Cada época não só sonha a seguinte, mas ao sonhá-la a força a despertar."

Walter Benjamin

Breve pesquisa literária sobre o tema Neurociência, Teatro e Terceira Idade, mostrou haver no Brasil, em geral, apenas relatos de experiências pontuais, como palestras, encontros, oficinas e cursos, sem, no entanto, evidenciar a relação dessas atividades com o funcionamento e atuação do Sistema Nervoso, como consta na programação cultural de instituições paulistas (Serviço Social do Comércio - SESC, Oficinas Culturais das secretarias de cultura do Estado e Município de São Paulo e dos programas Universidade Aberta à Terceira Idade da Universidade de São Paulo). Já os trabalhos acadêmicos no tema m questão como: "Arts in Dementia Care: "This is not the end... it's the end of this chapter", (Basting, 2006), estudo que destaca a importância das artes em benefício dos indivíduos com quadros de demência; "An Arts Intervention for Older Adults Living in Subsidized Retirement Homes', (Noice and Noice, 2008), concluem que há ganhos cognitivo, afetivo e fisiológico em um grupo de idosos participante de intervenção teatral; "Participating in a community theatre production: A dramatherapeutic perspective" (Pyman e Rugg, 2006), pesquisa qualitativa baseada na intervenção teatral como fator terapêutico; "Elders share the arts: transforming memory into art" (Zablotny 2006), texto que enfatiza a história pessoal dos atores como elemento de criação artística e contato entre as gerações, são contribuições produzidas principalmente nos Estados Unidos da América e na Inglaterra, entre as quais podem ser incluídos outros pesquisadores (tais como Kandell, 2006); de Mierre, 2004) Há, no entanto, significativa contribuição já estabelecida entre Neurociência e Arte, em geral, envolvendo a dança, o teatro, a pintura, a música, a estética, tanto nacionais como estrangeira, como são, para citar alguns deles, os trabalhos "A neurociência e o ensino e aprendizagem das artes", (Cury, 2008), que correlaciona aspectos fisiológicos e funcionais do SN à aprendizagem em artes; "Dance and Brain", de Scott Grafton e Emily Cross (Gazzaniga, 2008), que conclui serem as regiões cerebrais motoras, associativas e de linguagem igualmente ativadas tanto na execução física como observacional no aprendizado de dança. Nesse tópico, os pesquisadores Mônica Medeiros Ribeiro e Antonio Lúcio Teixeira, da Universidade Federal de Minas Gerais - UFMG identificaram os estudos de Zeki (2001) sobre visão e arte; e do Ramachandran (1999) sobre a percepção e estética da arte. Em dança, especificamente, eles citam as pesquisas de Hagendoorn (2004) e Brown e Parsons (2006); 
em teatro, circo e ópera eles citam pesquisadoras como Calvo Merino e colaboradores (2008), e fazem comentários sobre as observações do pesquisador Gazzaniga (2008), que relaciona o aumento da capacidade de estabelecimento de memória por identificação e compreensão de signos e símbolos manipulados no fazer cênico, bem como no recrutamento de circuitos neurais que suportam a organização de ações complexas.

Entretanto, a maioria desses estudos carece de experimentação e avaliação com o que esta pesquisa busca, de forma inédita, contribuir ao propor avaliar a hipótese de que o "Fazer Cênico" e "Atividade autobiográfica e literária" contribuem à melhora de parâmetros morfológicos, fisiológicos, comportamentais, gerando por conseqüência melhor qualidade de vida à população idosa. 


\section{OBJETIVO}

Esta pesquisa objetivou compreender e avaliar a influência do exercício das artes cênicas, estudo e prática (grupo 2 - G2), bem como da atividade autobiográfica e literária (grupo 1 - G1), em grupos com idade superior a 60 anos, pela análise de parâmetros qualitativos, fisiológicos, bioquímicos e suas eventuais consequências, ganhos, na expressão física (movimento, postura, equilíbrio, peso, anatomia) e comportamental a fim de verificar a relevância da adoção dessas atividades por essa população quanto a melhor qualidade de vida.

\subsection{Objetivos específicos}

3.1.1. Identificar e caracterizar os grupos da pesquisa, por meio de entrevista, questionário, informações sociodemográficas e culturais.

3.1.2. Avaliar a condição física dos participantes desses grupos em 2 momentos: início e fim da pesquisa, a fim de identificar parâmetros fisiológicos (análises clínicas), que pudessem constituir restrições às atividades propostas; e avaliar eventuais alterações da performance física (funcional, mobilidade e equilíbrio).

3.1.3. Identificar as condições cognitivas dos participantes pela aplicação do CAMCOG - Cambridge Cognitive Test, antes e após o treinamento oferecido aos grupos da pesquisa.

3.1.4. Avaliar, por meio de questionários, a compreensão de conteúdos trabalhados em vários momentos da atividade proposta, e verificar eventual ganho, direto ou indireto, com o desenvolvimento da atividade quanto a motivação e sociabilidade.

3.1.5. Avaliar qualitativamente os ganhos em sociabilidade, desempenho e compreensão dos grupos nas propostas oferecidas por meio de fotos, vídeos e depoimentos. 


\section{MATERIAIS E MÉTODOS}

Conforme Resolução número 196/96, que determina as diretrizes e normas regulamentadoras de pesquisa com seres humanos, este projeto foi aprovado pelo Comitê de Ética em Pesquisa Humana do Hospital Universitário da Universidade de São Paulo, CEPHU-USP em 17 de junho de 2011, conforme Apêndice I, página 143. Para o recrutamento dos participantes na pesquisa, a divulgação do projeto focalizou o público atendido nas Unidades Básicas da Saúde - UBS - da capital: Pinheiros, Vila Romana, Perdizes e Vila Anglo, bem como os participantes ou interessados no Programa Universidade Aberta à Terceira Idade, da Pró-Reitoria de Cultura e Extensão Universitária da Universidade de São Paulo. Como estratégia para atrair essa população para a pesquisa, foi postada mensagem no blog: www.teatroterceiraidade.blogspot.com, enviados press-releases à imprensa eletrônica e impressa de São Paulo, por meio da equipe de assessoria de imprensa da Estação Ciência, e distribuição ao público do flyer, Anexo I, página 188, com informes sobre a pesquisa a ser desenvolvida.

Os critérios de exclusão abrangeram cidadãos idosos com doenças neurológicas graves ou degenerativas, em situação de residentes asilares e de casas de repouso, dependentes de acompanhantes ou acamados e impossibilitados de participação ativa na sociedade.

Foram recrutados inicialmente 27 cidadãos com idade acima de 60 anos, socialmente ativos, de ambos os sexos, moradores da cidade de São Paulo, SP, Brasil, que no ato da inscrição responderam à entrevista individual e assinaram o Termo de Consentimento Livre e Esclarecido (TCLE). O Grupo 1 (G1) foi formado com doze integrantes e se caracterizou por ser composto por pessoas sem interesse em teatro e dança, mas voltado à pesquisa e escrita autobiográfica, sendo que aos mesmos foi oferecido o curso "Encontros para resgate de memória autobiográfica", coordenado pela bióloga e historiadora Neuza Guerreiro de Carvalho, no período de 8 de agosto a 05 de dezembro de 2011, às segundas-feiras, das 14 h00 até as 16h30, em uma das salas da Estação Ciência. No total, foram 18 encontros que compilados em um livro artesanal, feito pelos próprios participantes, com as suas histórias pessoais, concluíram o estudo. 


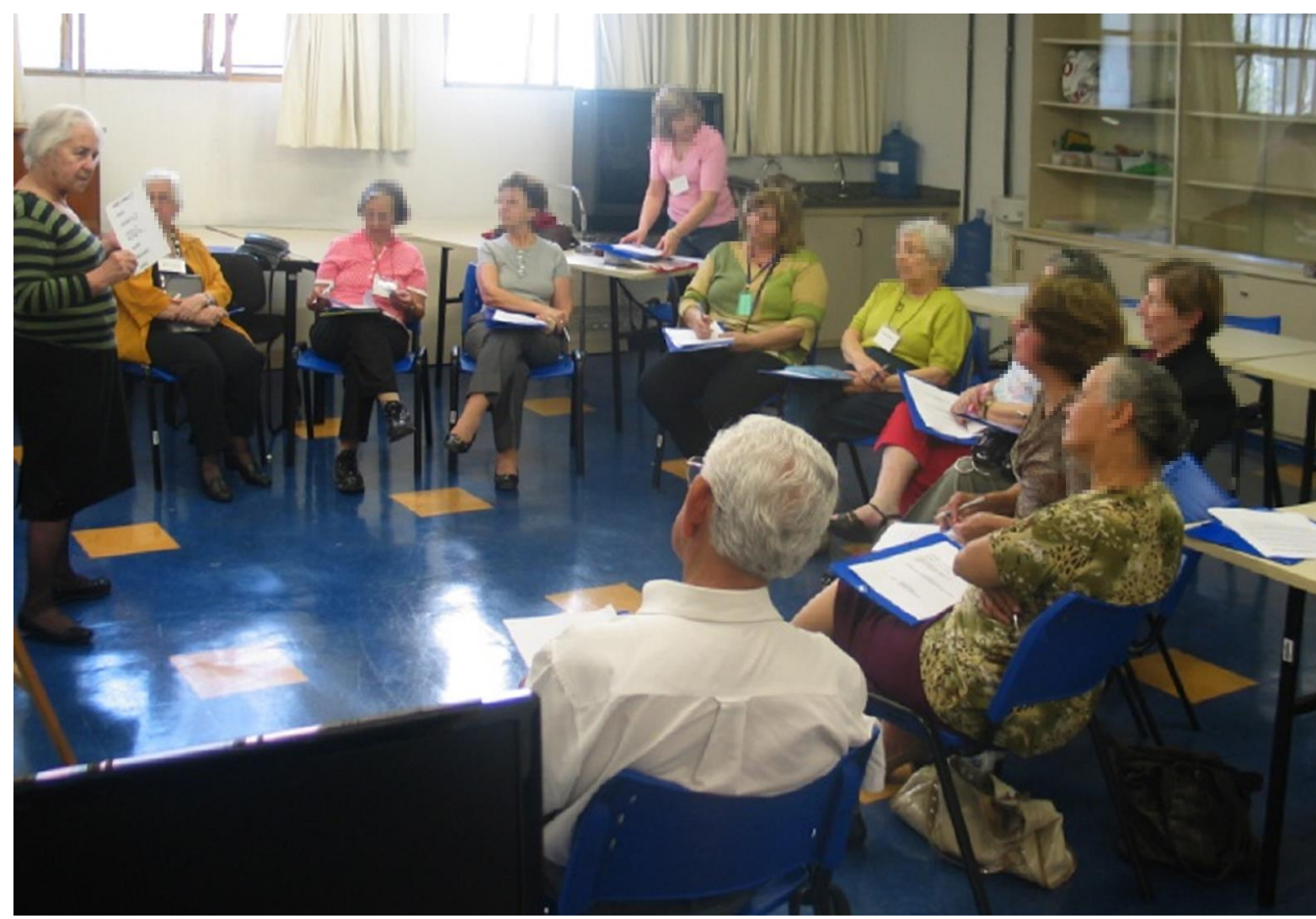

Figura 3. Fotografia da aula introdutória do curso "Encontros para resgate de memória autobiográfica" com voluntários da $3^{\mathrm{a}}$ idade - Grupo 1. Fonte: arquivo NACEC. (2011).

O grupo de resgate de memória autobiográfica trabalhou em sala, inicialmente se conhecendo mutuamente, discutindo as atividades propostas e depois as elaborando em sala, conforme figura 3. Essa atividade se caracterizou por organizar as lembranças pessoais e incentivar o enfoque autoral para produção de livro artesanal. As oficinas objetivaram registrar fatos, emoções, realizações e testemunhos como uma manifestação pessoal e cidadã, tanto para conhecimento da família como para contribuição ao grupo e sociedade. O critério para participação no grupo considerou "pessoas que já viveram mais de meio século, possuem 'juventude acumulada', foram testemunhas de muitos acontecimentos sociais portanto, têm memórias a registrar".

A metodologia focalizou a reconstrução literária da história de vida de cada participante para a produção de "Caderno resumo das atividades pessoais". As oficinas foram desenvolvias com dinâmicas que envolveram atividades de arte-terapia, desenho, pintura, escritos, música, canto, recortes de textos de autores conhecidos, criações de poemas e narrativas escritas individuais e coletivas, leituras e busca em arquivos pessoais, sejam de memória, fotos e vídeos. 
O desenvolvimento do curso reservou seus primeiros momentos à leitura e discussão de textos de apoio sobre o tema do dia, com todos os participantes em roda. Após essa etapa inicial, foi proposto intervalo de 15 minutos para socialização. No segundo momento do encontro foi feita divisão dos participantes em grupos com quatro pessoas no máximo, no que foi observado o cuidado de sempre formar grupos diferentes em cada encontro para escrever o que foi verbalizado sobre o tema do dia. Os temas trabalhados foram:

1. Identidade.

2. Os sentidos e a memória.

3. Infância.

4. Escolas e professores.

5. Juventude.

6. A família que recebi.

7. Vida afetiva.

8. A família que constituí.

9. Minhas fotos significativas.

10. Espaços de vivência - cidade e bairro.

11. Espaços de vivência - rua e casa (s).

12. Espaços de convivência - A Estação Ciência.

13. Leituras apreciadas.

14. Objetos biográficos.

15. Vida atual - Perspectivas / Sonhos.

16. Mensagem.

17. Avaliação - finalização dos cadernos.

Os textos produzidos nas oficinas a partir dos temas foram complementados durante a semana, em casa, revistos e discutidos por todo grupo no encontro seguinte.

O Grupo 2 (G2) foi formado com quinze integrantes, a maioria leiga em artes cênicas, este passou a integrar o projeto Só com Experiência, pertencente ao Núcleo de Artes Cênicas da Estação Ciência - USP. O estudo com esse grupo foi realizado entre os meses de julho de 2011 e fevereiro de 2012. A princípio, o período de sua realização coincidia com o do G1, porém, com a chegada do fim do ano e as demandas familiares dessa população nessa época do ano, não foi possível finalizar o espetáculo e apresentá-lo ao público, como o próprio projeto objetivou, pelo que a atividade foi retomada no dia 10 de janeiro de 2012 e finalizada 
no dia 12 de fevereiro 2012, com a devida apresentação ao público no teatro Estação Ciência, São Paulo, às 16 horas, tendo a presença de sessenta pessoas na plateia. No total, foram 25 encontros realizados semanalmente, às terças-feiras, com três horas de duração, com o devido treinamento proposto sobre os aspectos fundamentais da ação cênica em dança e teatro:

\section{Estudos sistêmicos, anatômicos e de ideokinesis}

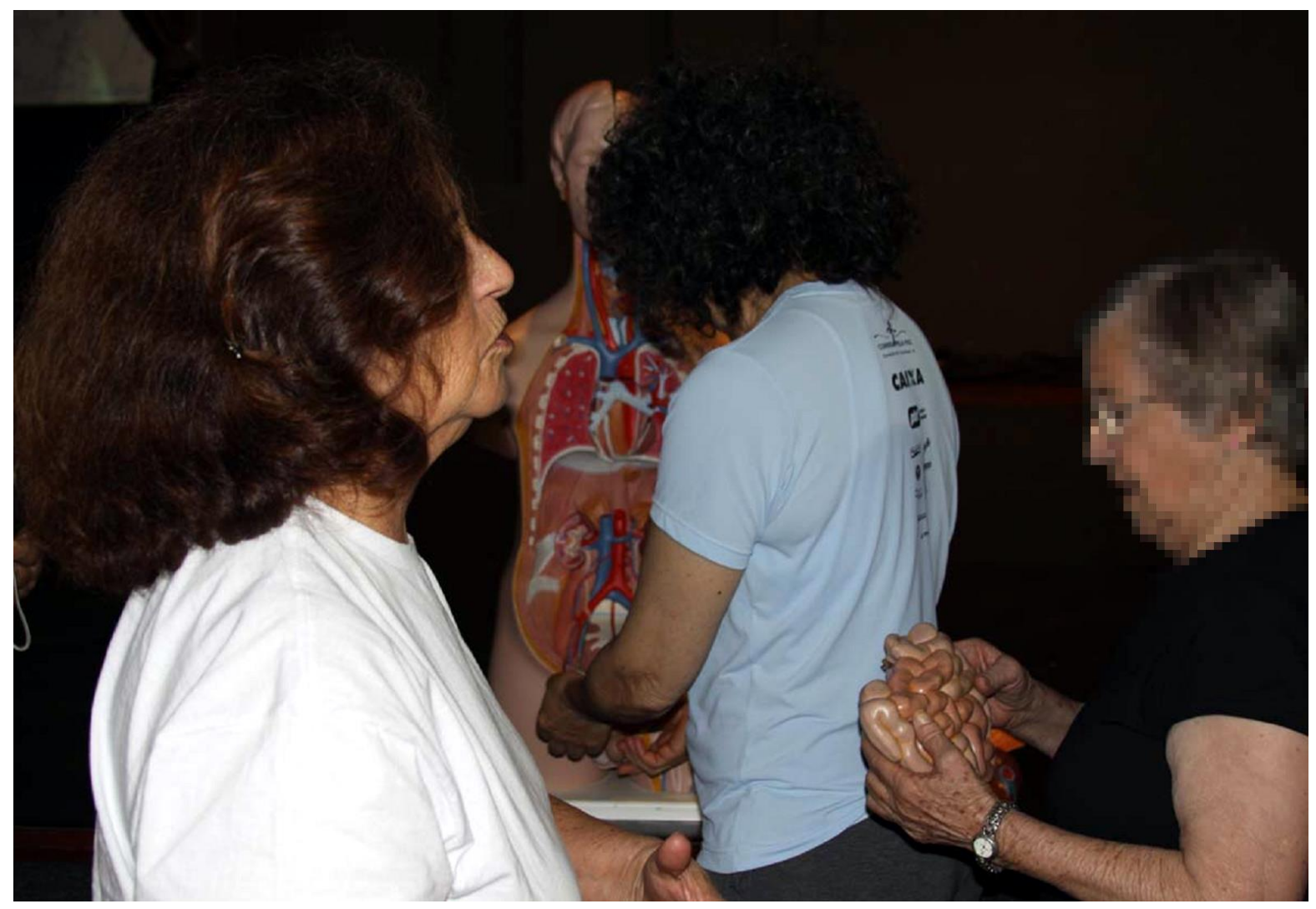

Figura 4. Fotografia de estudos sistêmicos, anatômicos e de ideokinesis com voluntários da $3^{\mathrm{a}}$ idade, integrantes do Grupo 2. Fonte: arquivo NACEC. (2011).

O estudo ficou centralizado em três Sistemas Orgânicos, como mostrado no quadro abaixo, sem, no entanto, deixar de realizar, quando necessário, oportunas abordagens de outros sistemas, tais como: o Endócrino, Digestório, Renal, entre outros. Nos três sistemas mais abordados pela atividade, um por um, por meio de modelos disponíveis, livros de anatomia ou painéis explicativos, ênfase foi dar a conhecer suas estruturas e funções caracterizadas por ação global sobre o funcionamento do corpo e sua importância na realização cênica. 
Quadro 1. Aspectos envolvidos e trabalhados na pratica cênica com voluntários da $3^{\mathrm{a}}$ Idade - G2.

\begin{tabular}{|c|c|c|c|c|}
\hline SISTEMA & $\begin{array}{l}\text { ÓRGÃOS ou } \\
\text { ESTRUTURAS } \\
\text { ENVOLVIDAS }\end{array}$ & $\begin{array}{c}\text { FUNÇÃO no } \\
\text { TRABALHO } \\
\text { CÊNICO } \\
\end{array}$ & $\begin{array}{c}\text { ASPECTOS } \\
\text { COMPORTA- } \\
\text { MENTAIS } \\
\end{array}$ & $\begin{array}{l}\text { MODALIDADES } \\
\text { SENSORIAIS }\end{array}$ \\
\hline Cardiorrespiratório & $\begin{array}{l}\text { Coração } \\
\text { Nariz } \\
\text { Boca } \\
\text { Faringe } \\
\text { Laringe } \\
\text { Traquéia } \\
\text { Brônquios } \\
\text { Pulmões }\end{array}$ & $\begin{array}{l}\text { Canto } \\
\text { Voz } \\
\text { Interpretação }\end{array}$ & $\begin{array}{l}\text { Atenção } \\
\text { Emoção } \\
\text { Memória } \\
\text { Prosódia } \\
\text { Aprendizado }\end{array}$ & $\begin{array}{l}\text { Audição } \\
\text { Olfação }\end{array}$ \\
\hline Pele & $\begin{array}{l}\text { Pele }= \\
\text { Receptores } \\
\text { sensoriais }\end{array}$ & Sensibilização & $\begin{array}{l}\text { Percepção } \\
\text { sensorial }\end{array}$ & $\begin{array}{l}\text { Propriocepção } \\
\text { Tato } \\
\text { Pressão } \\
\text { Temperatura }\end{array}$ \\
\hline Musculoesquelético & $\begin{array}{l}\text { Músculos } \\
\text { Tendões } \\
\text { Ligamentos } \\
\text { Ossos } \\
\text { Articulações }\end{array}$ & $\begin{array}{l}\text { Expressão } \\
\text { Corporal } \\
\text { Interpretação }\end{array}$ & $\begin{array}{l}\text { Flexibilidade } \\
\text { Movimento }\end{array}$ & Visão \\
\hline
\end{tabular}

Cada um desses sistemas foi objeto de atenção, pesquisa e sensibilização no corpo do próprio participante do grupo de pesquisa, que, após esse aprendizado de caráter mais científico, utilizou gestos e expressões corporais, focalizados sobre a região do órgão ou das estruturas estudadas, para criar situações cênicas que expusessem um sentimento, emoção, pensamento ou mesmo uma curta história com início, meio e fim. Esse estudo foi efetuado a partir de observações sobre os órgãos mais interiores para aqueles situados na periferia do corpo, sendo a pele o último sistema abordado. Como exemplo da aplicação dessa metodologia, segue síntese do estudo feito sobre o Sistema Musculoesquelético. Fundamentados por autores como Netter (2008), Moore \& Agur (2004), entre outros, e com uso de modelos em resina para estudos observacionais e de manipulação os participantes do G2 verificaram cada um dos 206 ossos e os mais de 600 músculos esqueléticos que compõem o Sistema Musculoesquelético humano, por catalogação e reconhecimento do nome, formato, 
textura, tamanho e localização no corpo, bem como suas várias possibilidades de movimento. Em todo o estudo, a cada encontro, após o contato direto e manual com os modelos em resinas, foi solicitado que o participante se observasse e reconhecesse no próprio corpo o osso e/ou músculo pesquisado, com o intuito de, em seguida, conscientemente realizar movimentos corporais focalizados sobre a região ou a parte do corpo sob observação. Após esse processo de reconhecimento e consciência corporal, os participantes recriaram, de forma expressiva, uma história, um sentimento, emoção ou pensamento para, na sequência, ser analisado e discutido com os outros integrantes o grau de entendimento e compreensão do exercício executado.

2. Estudos e improvisações com enfoque na consciência corporal através do desenvolvimento das técnicas do movimento consciente e contato-improvisação.

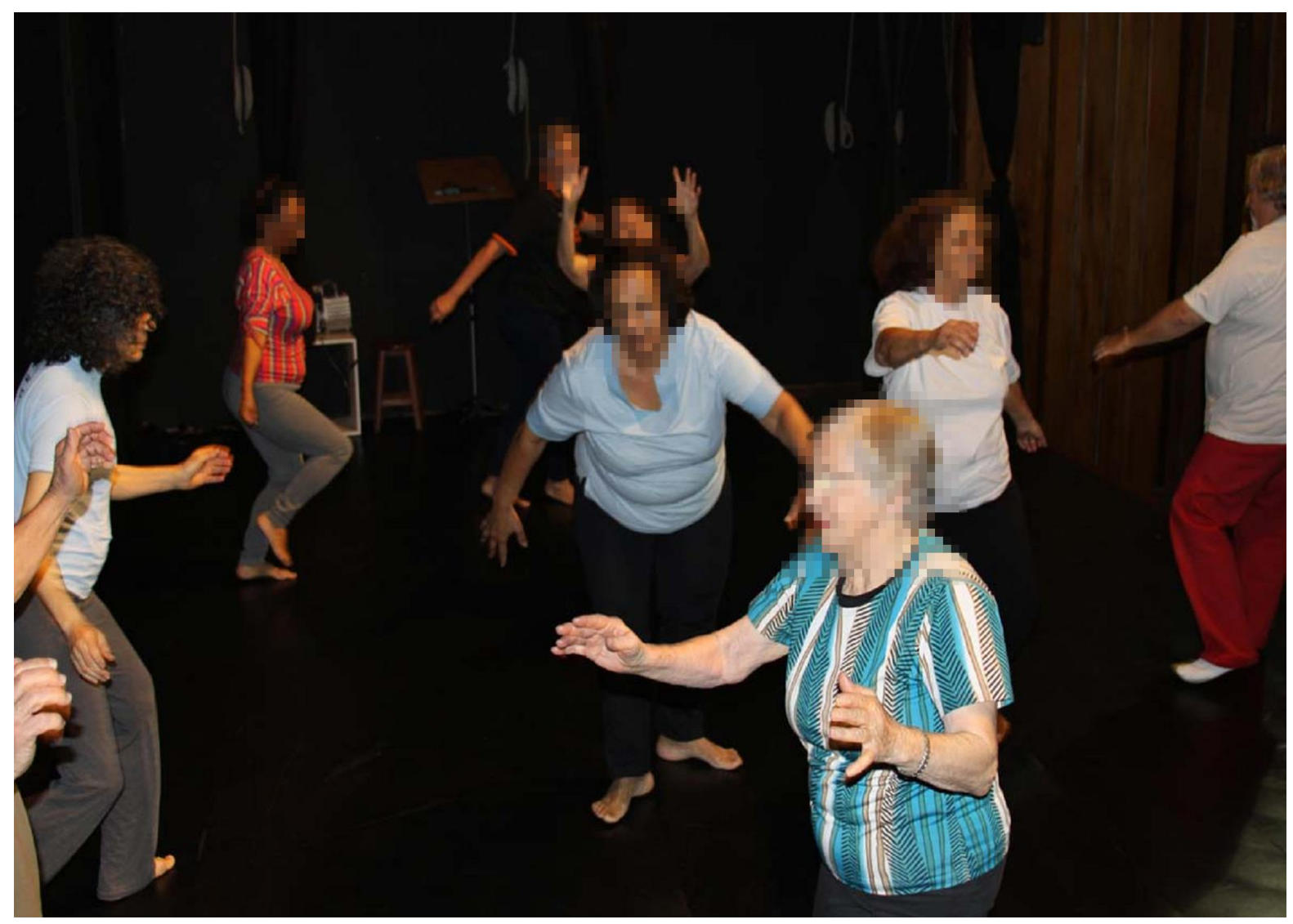

Figura 5. Fotografia de registro da aula de improvisação cênica corporal com voluntários da $3^{\mathrm{a}}$ idade, integrantes do Grupo 2. Fonte: arquivo NACEC. (2011)

Nesse momento do desenvolvimento da atividade, as possíveis elaborações perceptuais de esquemas da imagem corporal desenvolvidas pelas etapas anteriores, onde a 
ideokinesis $^{3}$ foi o ponto chave para compreender a sua dinâmica e resultado, foram agregados outros estudos, com a finalidade de ampliar aos participantes à conscientização e conhecimento sobre o seu corpo. Desta forma, conteúdos teóricos e os exercícios práticos foram utilizados em técnicas corporais para o estudo do movimento consciente desenvolvidas por Moshe Feldenkrais, Rudolf Laban e Klauss Vianna, com o objetivo de preparar o corpo do ator para a compreensão da espacialidade, tempo, ritmo, força, impulso, equilíbrio, estímulos sensoriais, respostas neuronais e a ação comportamental executada. Nessa etapa, o fundamental foi trazer a percepção física, vivencial, do aqui e agora. $\mathrm{O}$ estar presente para responder aos estímulos provocados pelas situações cênicas ou mesmo pelo próprio corpo, internamente.

- Aplicação em dança contemporânea

A dança trabalhada nesse momento foi a forma de contextualizar expressivamente todos os estudos anteriores e preparar ou mesmo verificar o grau de atenção corporal adquirido pelos participantes. Mas, antes de tudo, dar o treinamento possível para que o movimento fosse executado com segurança, harmonia, equilíbrio e poesia. Sem tensão ou exageros, buscando relação direta com o outro e com o espaço, atento aos estímulos e às possibilidades de se criar uma dramaturgia corporal espontânea, livre e pessoal. A técnica desenvolvida foi baseada no Contato-Improvisação, Nova Dança criada na década de 1970, por Steve Paxton (Gil, 2008). O "Contato-Improvisação" se caracteriza por ser um sistema básico de entendimento mútuo. A comunicação se dá por meio da integração de pontos de contato entre os participantes, que processa massa, vetores, emoções, tensões, e equilíbrio, sem perder a objetividade cênica, a presença física, a relação com o outro (pessoa, estímulo, ambiente...), sem se subjetivar.

3 Ideokinesis: "Ideo: ideia; Kinesis: movimento, ou movimento imaginado". Método educacional que se utiliza de imagens para remodelar o sistema neuromuscular. 
3. Método de desenvolvimento cênico, a partir da história e experiência pessoal, de narrativas corporais que construíram os quadros de cena do espetáculo.

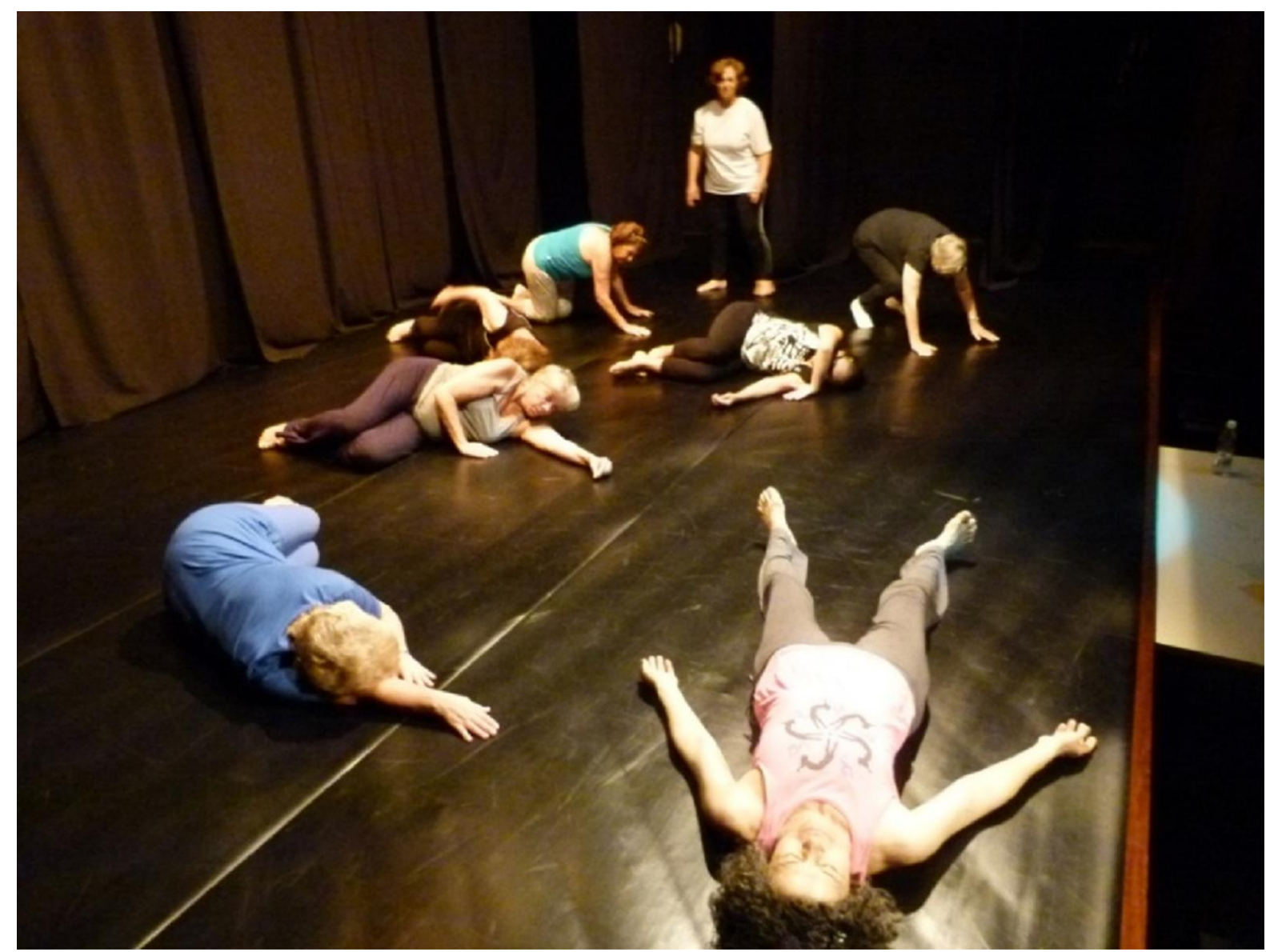

Figura 6. Fotografia de narrativas em situação cênica com voluntários da $3^{\mathrm{a}}$ idade, integrantes do Grupo 2. Fonte: arquivo NACEC. (2011).

Como sequência e aprimoramento do conhecimento sobre o fazer cênico, houve aqui a introdução de exercícios e prática em que corpo, voz, vivências pessoais e leituras formaram um só bloco de ação, para que a espontaneidade e criatividade, aliadas ao conhecimento das técnicas e referências trabalhadas anteriormente, determinassem a situação e ambiente cênicos desejados. Esses exercícios são caracterizados por sistemas de jogos e improvisações baseados em estudos, releituras, adaptações ou adequações de sistematizações de dinâmicas já consolidadas na prática (Boal ,1998; Spolim, 2008, 2010; e Novelly, 1996). Além da capacitação, esta atividade objetivou fornecer subsídios para criação do roteiro cênico, texto, utilizado no espetáculo concebido e apresentado pelo grupo.

Como método de aplicação do fazer cênico, esses encontros foram muito importante para evidenciar o nível de compreensão e apreensão adquirido em todas as atividades 
desenvolvidas. Foi o momento para avaliar quanto o grupo, ou o individuo, adquiriu de novas habilidades, conceitos, motivação e cumplicidade pelo treinamento oferecido. Assim como, possibilitaram ao participante refletir sobre seu lugar no grupo, na peça, e o quanto sua capacidade de agregar novas ideias e treinamentos estava disponível para o desenvolvimento da ação cênica. Dessa forma, o trabalho do ator/atriz foi potencializado e ganhou força para a construção dos seus personagens. E como não deveria deixar de ser, a resposta em cena evidenciou que muito do que se trabalhou ali está presente, em ações, gestos, voz e preenchimento do espaço de cada integrante do grupo. Assim, ao expressarem a consciência desses elementos e do contexto no qual estavam inseridos nas cenas em desenvolvimento, esse método possibilitou ao grupo deixar transparecer a perspectiva de uma encenação com interpretações convincentes, sensíveis e transformadoras.

4. Finalização da atividade com montagem do espetáculo "Histórias de Mulheres", e apresentação aberta ao público.

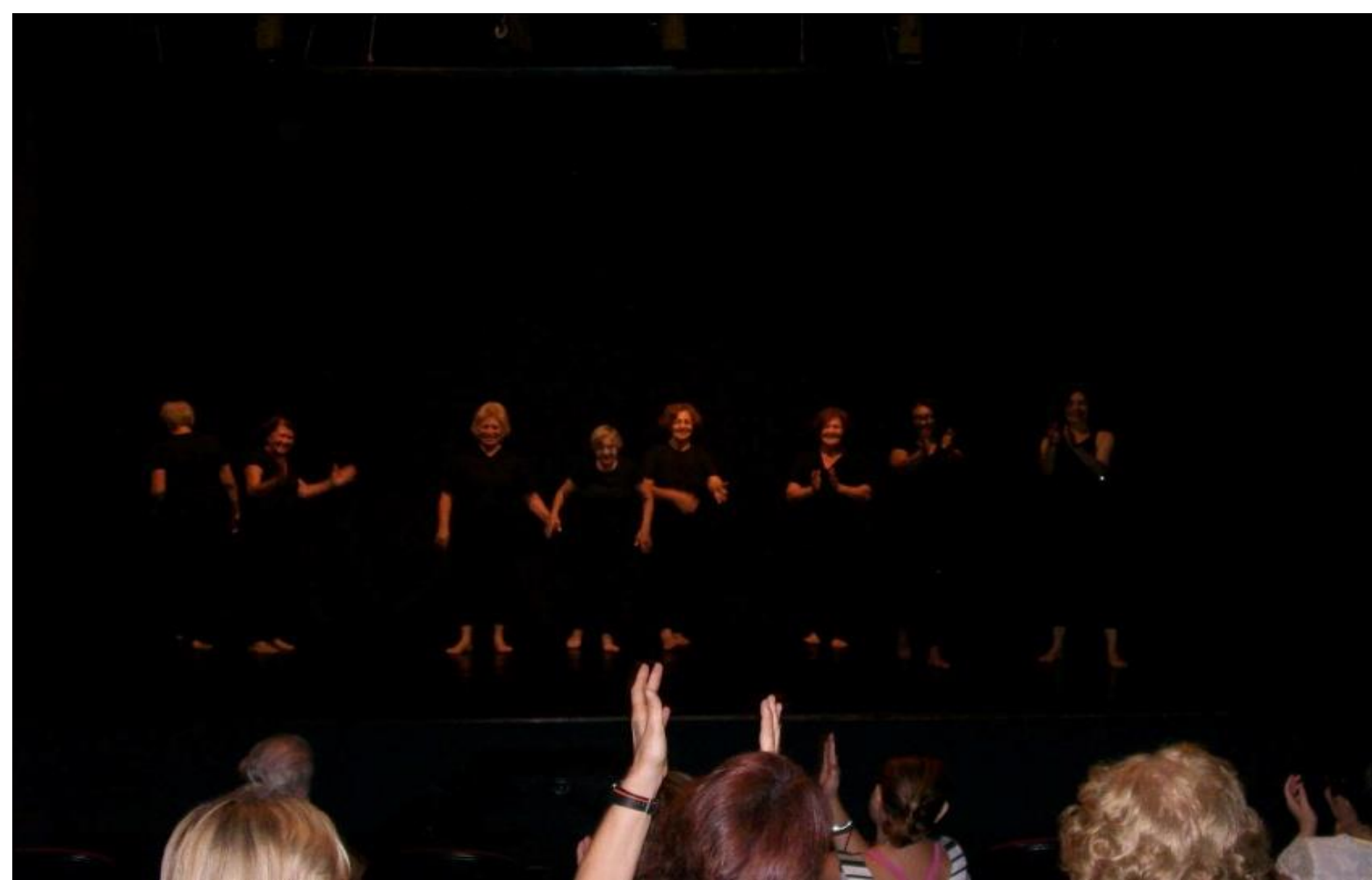

Figura 7. Fotografia do público aplaudindo a apresentação do espetáculo "Histórias de Mulheres", no Teatro Ernst W. Hamburger (Estação Ciência - USP) realizado pelos voluntários da $3^{\text {a }}$ idade, integrantes do Grupo 2. Fonte: arquivo NACEC. (2012).

Última etapa do processo de sistematização e procedimentos da pesquisa, cuja finalização culminou com a exposição pública da obra criada. Buscando conciliar a 
abordagem teórica com a motivação física e artística em cena, para se chegar ao espetáculo final e sua apresentação ao público, autores como David Ball (2006), Manfred Wekwerth (1997) e Peter Book (1970) ofereceram caminhos e orientações para atingir com segurança esse objetivo final. Ao que foi trabalhado em etapas anteriores - corpo, voz, interpretação, e, agregado a esses, os recursos técnicos e de complementação à criação da obra cênica, como iluminação, cenário, figurino, trilha sonora etc, foram agregados também conteúdos científicos na construção do espetáculo, bem como explanações e práticas sobre a forma, métodos, segredos e truques do ofício cênico. Diversas peculiaridades dos processos e procedimentos da prática cênica foram disponibilizadas aos atores e atrizes envolvidos na montagem e finalização do espetáculo. Essa interface teórica e prática evidenciada na concepção da obra cênica foi um pressuposto para que o elenco, equipe de criação e técnicos se sentissem em ambiente seguro. A obra criada, a concepção do espetáculo, o jogo e cumplicidade entre os atores e atrizes, a cooperação mútua, a exposição coletiva e individual, a reação e retorno do público foram os indicadores de percepção do nível de aprendizagem alcançado e fatores de avaliação de todo processo desenvolvido.

Paralelamente à realização das atividades com os grupos G1 e G2, foram feitas verificações qualitativas por questionários, testes, exames clínicos e medidas antropométricas, bem como coleta de dados quantitativos dos voluntários participantes por meio de entrevistas individuais e em grupo, registro de imagens e depoimentos escritos e em vídeo.

A pesquisa quantitativa, realizada pré e pós-treinamento, buscou identificar e avaliar a condição física, cognitiva, clínica e percepção de qualidade de vida dos participantes do grupo, e verificar eventuais ganhos nesses índices, pelo desenvolvimento das atividades propostas, tendo assim possibilidades de análise funcional, de autonomia, percepção subjetiva, mobilidade, equilíbrio e mensuração metabólica e bioquímica. Para tanto, foram utilizados os questionários de Informações Sociodemográficos (IS) e de qualidade de vida World Health Organization Quality of Life - Bref e Old - WHOQOL-Bref e WHOQOL-OLD (Fleck et al, 2003); os testes de capacidade funcional - Six-Minute Walk Test (Troosters, 1999), (Steele, 1996); Timed Up and GO Test (Podsiadlo, Richardson, 1991); e One-Leg Balance Test (Vellas, 1997); e os exames mental e clínico - CAMCOG - Cambridge Cognitive Test, dosagem do colesterol total, HDL-colesterol, LDL-colesterol, triglicérides, glicemia, hemograma completo, eletrocardiograma e medidas antropométricas. 
Questionário de Informações Sociodemográficas

O Questionário Informações Sociodemográficas (IS) é importante recurso para identificar variáveis como: gênero, idade, altura e peso (questões 1,2,3,4 e 5), identificação socioeconômica e cultural (questões $6,7,8,9,10,11,12$ e 13), sua preferência em relação a atividades de lazer (questões 14, 15 e 16), sua percepção quanto à saúde (questões 17, 18, 19, 20, 21 e 24), quantidade de práticas físicas e autoavaliação motora (questões 22, 23, 29 e 30) e percepção cognitiva (questões 25, 26, 27 e 28). Foi empregado apenas uma vez, no ato da inscrição, sendo preenchido pelo participante sem auxílio de assistentes ou pesquisadores.

A altura e o peso por não constarem no questionário IS foram obtidos das medidas antropométricos realizados pela equipe do ELSA - Estudo Longitudinal de Saúde do Adulto.

WHOQOL-Bref (Fleck et al, 2000) e WHOQOL-OLD (Fleck et al, 2003, 2006).

Esses questionários foram aplicados individualmente junto aos voluntários dos grupos da pesquisa, em dois momentos, no pré e no pós-treinamento. O WHOQOL-Bref é uma versão abreviada do instrumento WHOQOL-100 (1995), desenvolvido pela Organização Mundial da Saúde - OMS. Ele é composto por 26 questões, sendo que duas avaliam aspectos relacionados à Qualidade de Vida global e 24 correspondem aos domínios Físico, Psicológico, Relações Sociais e Meio Ambiente (Alexandre et al, 2009). O domínio Qualidade de Vida (QV) corresponde às questões 1 e 2, enquanto o Domínio Físico (DF) é avaliado pelas questões $3,4,10,15,16,17,18$, que envolvem perguntas com interesse sobre aspectos diretamente relacionados com a identificação de dor e desconforto, estados de energia e fadiga, mobilidade, atividades da vida cotidiana, dependência de medicação ou de tratamento e capacidades de execução das tarefas diárias, tendo sido o processo de envelhecimento avaliado por sua ação sobre os órgãos estruturais corporais em declínio (Meireles et al, 2008. As questões 5, 6, 7, 11, 19 e 26 correspondem ao Domínio Psicológico (DP) e dizem respeito à avaliação de sentimentos positivos e negativos, forma de pensar, aprender, memória e concentração, autoestima, imagem corporal, aparência e espiritualidade (Grupo Whoqol, 1998b). O Domínio Social (DS), ou Relações Sociais, referente às questões 20, 21 e 22, mensura as relações pessoais, apoio social e a atividade sexual. Aspectos relacionados à segurança física, ambiente no lar, recursos financeiros, cuidados de saúde e sociais; disponibilidade e qualidade, atualidades, habilidades, diversão e lazer, meio físico - poluição, 
ruído, trânsito e clima, e transporte (Grupo Whoqol- 1998b) - foram contemplados nas questões 8, 9, 12, 13, 14, 23, 24 e 25, que correspondem ao Domínio Meio Ambiente (DMA).

O questionário WHOQOL-OLD, constitui ferramenta muito importante para avaliar a qualidade de vida propriamente dita (Pedroso et al, 2011) tal quais os questionários WHOQOL-100 e WHOQOL-Bref, porém, é específico para a população idosa acima de 60 anos de idade. Ele é composto por 24 questões, que resultam na avaliação de seis facetas: Funcionamento Sensorial (FS) (Habilidade Sensorial), questões 01, 02, 10 e 20; Autonomia (AUT), questões 03, 04, 05 e 11; Atividades Passadas, Presentes e Futuras (PPF), questões 12, 13, 15 e 19; Participação Social (PSO) questões 14, 16, 17 e 18; Morte e Morrer (MEM), questões 06, 07, 08 e 09; e; Intimidade (INT), questões 21, 22, 23 e 24, que formarão a faceta Global sobre as questões do envelhecimento (Power et al, 2005). Ele tem por objetivo realizar um estudo transcultural, comparando o envelhecimento saudável e o envelhecimento patológico (Loures et al, 2010).

A faceta Funcionamento dos Sentidos avalia o estado atual dos cinco sentidos do indivíduo e como suas condições podem repercutir no cotidiano, na execução de atividades diárias ou mesmo na interação social (Fleck e Chachamovitch, 2005). A faceta Participação Social aborda a satisfação pessoal com atividades diárias, uso do tempo e oportunidades de participar de atividades em comunidade (Chachamovitch e Fleck, 2005). A faceta Autonomia busca avaliar o quanto a pessoa tem de liberdade para tomar suas próprias decisões, assim como o quanto ela acredita que as outras pessoas consideram e respeitam sua maneira de ser e de agir no mundo. A faceta Atividades Passadas, Presentes e Futuras busca identificar o quanto a pessoa está satisfeita consigo mesma por aquilo que conquistou ou alcançou, com as possibilidades de obter novas realizações, com o grau de reconhecimento merecido na vida e expectativa futura (Chachamovitch e Fleck, 2005. A faceta Morte e Morrer avalia as preocupações, inquietações e temores sobre a morte e sobre morrer (Chachamovitch e Fleck, 2005) e a faceta Intimidade mede a capacidade de ter relacionamentos pessoais e íntimos (Chachamovitch e Fleck, 2005). Por fim, o escore Global, avalia a qualidade de vida propriamente dita do participante. 


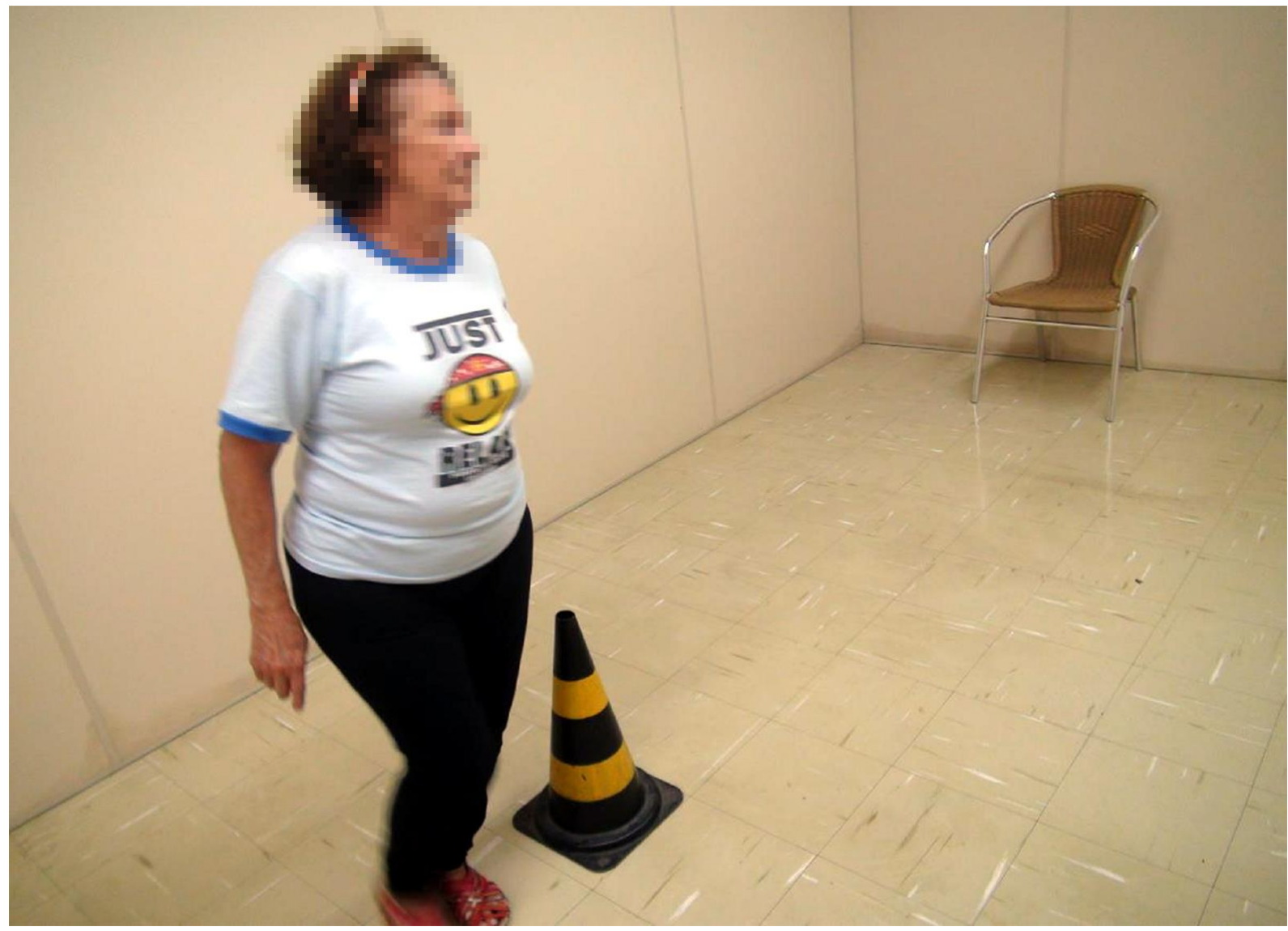

Figura 8. Fotografia de voluntário da $3^{\mathrm{a}}$ idade, integrante do Grupo 2, participando do Timed Up and GO Test. Fonte: arquivo NACEC. (2011).

É uma adaptação do Get up and go, de Mathias et al (1986). Ele é um teste válido e confiável (Smith, 2009), amplamente utilizado no exame de idosos (Bohannon, 2006), que avalia o equilíbrio do individuo quando sentado, transferência dessa posição para a posição de pé, estabilidade na deambulação e mudança do curso da marcha sem utilizar estratégias compensatórias (Soares et al, 2005). A realização do teste junto aos grupos 1 e 2, medido em segundos, foi padronizada e seguiu o protocolo recomendado na literatura (Podsiadlo, Richardson, 1991), (Smith, 2009), ou seja, foi solicitado aos voluntários que, ao ouvir a palavra "vai", se levantassem da cadeira, caminhassem a distância estabelecida de três metros, fizessem a volta na área delimitada e voltassem para o ponto inicial, a cadeira, e sentassem novamente (Silva et al, 2008). O teste foi feito individualmente, com e sem tarefa dupla. No primeiro teste (TUGT-1), o indivíduo simplesmente executou a tarefa estabelecida pelo protocolo, e no segundo, TUTG2, foi pedido ao participante que verbalizasse sua história de 
vida durante a execução da tarefa. Nos dois testes foi usada uma cadeira normal de plástico, com $45 \mathrm{~cm}$ de altura e parte traseira reta, encostada a uma parede, o que dava segurança e estabilidade à movimentação corporal empregada pelo voluntário. Assim, sob essas circunstâncias, foi possível analisar o desempenho pela contagem de tempo, com cronômetro, do aparelho celular LG, o que indicou se os valores obtidos correspondiam aos intervalos considerado normais para idosos saudáveis e independentes, que realizam o teste em até 10 segundos (Soares et al, 2005).

\section{- Six-minute Walk Test}

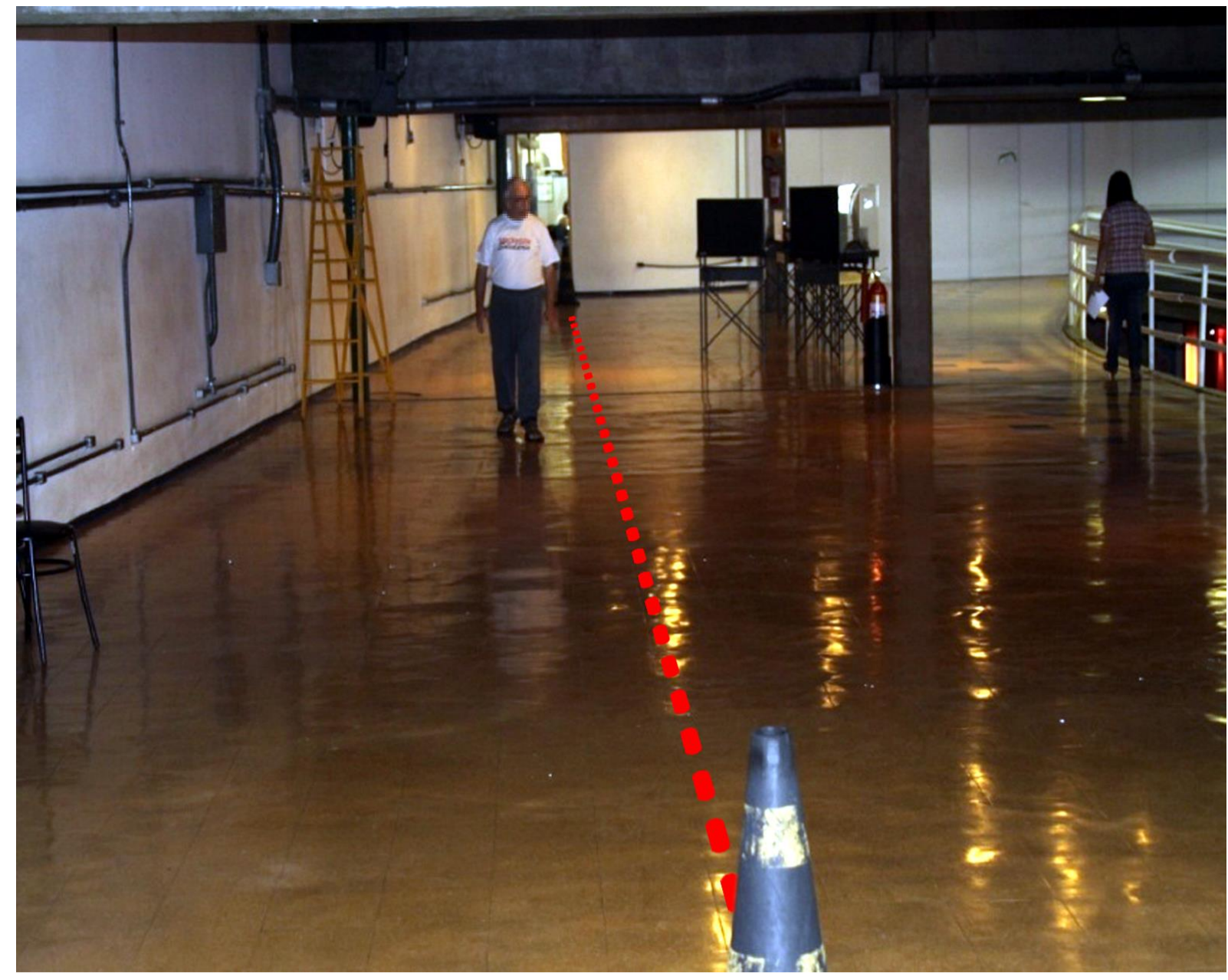

Figura 9. Fotografia de voluntário da $3^{\underline{a}}$ idade, integrante do Grupo 2, no The Six-Minutes Walk Test. Fonte: arquivo NACEC. (2011).

O Teste de caminhada de seis minutos (TC-6), foi comumente aplicado para aferir a capacidade funcional, estadiamento clínico e prognóstico cardiovascular (Cipriano Jr. et al, 2009). Trata-se de um instrumento válido (AACVPR, 2004), (SBC, 2002), confiável e 
amplamente descrito na literatura - (Troosters, 1999), (Enright, 2003), (Cipriano Jr. et al, 2009), (Demers et al, 2001), (Kervio et al, 2003), (Rejeski et al, 2000) entre outros, sendo ele o principal teste de caminhada utilizado na prática clínica (Britto e Souza, 2006). No entanto, aspectos de avaliação funcional (Solval et al, 2001), (Britner et al, 1993) requerem avaliações físicas, diretas, com o intuito de acentuar medidas que preveem a capacidade aeróbica máxima (Noonan e Dean, 2000). Estudos asseguram que, no TC-6, com pessoas saudáveis, as distâncias variam entre $400 \mathrm{~m}$ e $700 \mathrm{~m}$ (Enright, 2003), sendo realizado de forma comparativa, avaliando as intervenções, antes e depois da conduta empregada.

Durante a coleta de dados, foi seguida a recomendação postulada por Enright e Sherrill (1998), que sugerem a padronização (Steele, 1996) adequada da atividade física, assegurando assim os mesmos parâmetros de aferição para todos os voluntários. Foram usados cronômetro, do aparelho digital LG/celular; dois cones de borracha colocados em oposição delimitaram o corredor a ser usado na caminhada, com 30 metros de distância um do outro. Foi adotado como critério aplicar o teste com pelo menos duas horas após as refeições, sendo que os voluntários deveriam utilizar roupas e calçados confortáveis. Os voluntários realizaram dois testes com período de repouso de 15 minutos entre eles, para avaliar ocorrência de contra-indicações e/ou sintomas de desconforto físico (Enright, 2003) que exigissem a suspensão da atividade. Ainda, e, além disso, a repetição do teste visou eliminar o efeito aprendizado e assegurar a reprodutibilidade do procedimento (Britto e Souza, 2006);

\section{- One-leg Balance Test}

Este teste possibilita avaliar o equilíbrio estático do indivíduo, assim como identificar risco de quedas (Vellas et al, 1997) e entorse no tornozelo (Trojian e Mckeav, 2006). Estudos afirmam que adultos idosos incapazes de se equilibrarem em um pé durante cinco segundos têm sérias possibilidades de ter duas vezes mais quedas durante os próximos três anos em comparação com aquele que permanece em equilíbrio por mais de cinco segundos (Vellas et al, 1997). O protocolo recomenda que o cronômetro deve iniciar a contagem de tempo quando o indivíduo levantar um pé, dobrando o joelho cerca de 45 graus, devendo parar a contagem se o pé levantado começar a abaixar ou tocar no chão, oscilar o corpo e, quando de olhos fechados, o indivíduo abrir os olhos. Os parâmetros de tempo para avaliação levam 


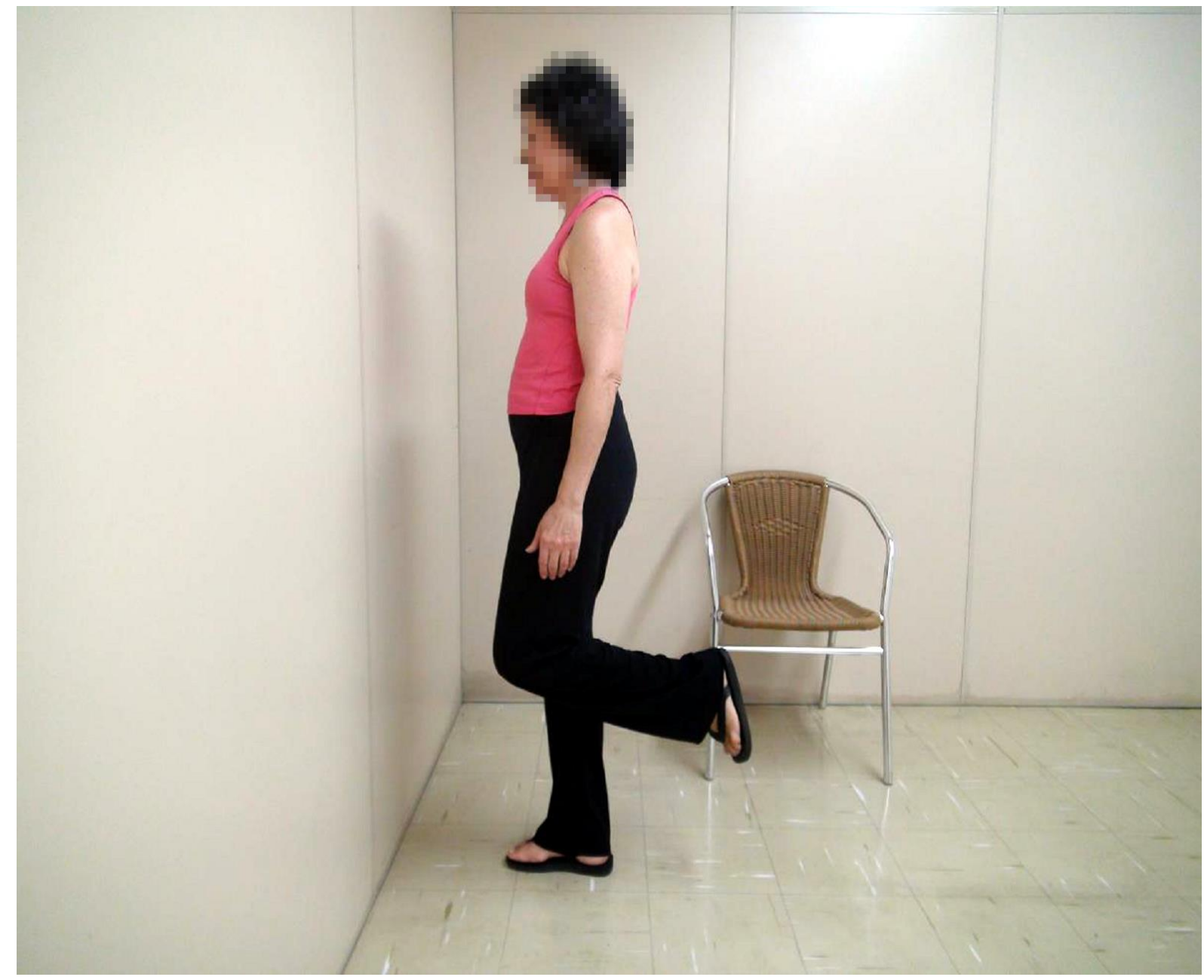

Figura 10. Fotografia de voluntária da $3^{\mathrm{a}}$ idade, integrante do Grupo 1, participando do On-Leg Balance Test. Fonte: Arquivo NACEC. (2011).

em conta que pessoas com idade entre 60, 65 e 70 anos permaneçam em equilíbrio com os olhos fechados por 7, 5 e 4 segundos, respectivamente, enquanto que, com olhos abertos, possam ficar até 27 segundos. O One-Leg Balance Test foi aplicado em nossa pesquisa levando em conta orientações da literatura, que recomenda padronização de procedimentos, ambiente seguro com proximidade de parede e acompanhante ao lado. Aos indivíduos, foi solicitado usar calçados de uso cotidiano, preferencialmente tênis, levantar a perna de lateralidade não dominante.

\section{CAMCOG - Cambridge Cognitive Test}

É um teste de perguntas abertas, com 187 itens a serem respondidos sobre aspectos cognitivos:

1. Orientação: tempo e local. Pontuação máxima 10. 
2. Linguagem: compreensão (resposta motora), expressão (registro verbal, nomeação, definições, repetição, discurso espontâneo). Pontuação máxima 30.

3. Memória: evocação, reconhecimento, recuperação de informação remota, recuperação de informação recente, registro. Pontuação máxima 27.

4. Atenção/concentração. Pontuação máxima 7.

5. Praxia. Pontuação máxima 12.

6. Cálculo. Pontuação máxima 2.

7. Pensamento abstrato. Pontuação máxima 8.

8. Percepção tátil. Pontuação máxima 2.

9. Percepção visual: pessoas famosas, objetos. Pontuação máxima 10.

A pontuação por item varia de um a seis, sendo que, quando o indivíduo erra, o valor a ser atribuído é 9 (porém não será marcado no escore geral). A pontuação total é de 107 pontos. Não tem ponto de corte por escolaridade. A validação desse teste no Brasil foi feita em 2001 por Bottino e colaboradores (Bottino et al, 2001). O teste neuropsicológico CAMCOG faz parte da entrevista estruturada do CAMDEX, sendo ele um dos instrumentos mais utilizados em todo o mundo para auxiliar no diagnóstico diferencial de transtornos mentais em indivíduos idosos. A partir das respostas e valores obtidos com o CAMCOG é possível encontrar também os escores para o Mini Exame do Estado Mental - MEEM. O MEEM (Folstein et al, 1975) é um instrumento mundialmente utilizado para avaliar funções cognitivas específicas, contendo questões agrupadas em sete categorias, a saber: orientação temporal (5 pontos), orientação espacial ( 5 pontos), registro de três palavras (3 pontos), atenção e cálculo ( 5 pontos), recordação das três palavras (3 pontos), linguagem ( 8 pontos) e capacidade construtiva visual (1 ponto). $\mathrm{O}$ escore do MEEM pode variar de 0 a 30 pontos indicando o grau de comprometimento e capacidade cognitiva dos indivíduos.

O teste foi aplicado em ambiente fechado, com atendimento individual feito por profissional credenciado pelo Instituto de Psiquiatria do IPq-USP.

Exames clínicos

Com o intuito de conhecer o estado de saúde e o perfil de fatores de risco para doença cardiovascular dos voluntários selecionados, foram feitos, logo no primeiro momento de contato com os pesquisadores, exames clínicos incluindo antropometria, medida da pressão 
arterial e coleta de sangue de todos os integrantes dos grupos da pesquisa, G1 e G2. Com procedimento de atendimento individual, para ambos os grupos da pesquisa os exames: medida de peso e altura, para cálculo do índice de massa corpórea (IMC); medida da circunferência da cintura e do quadril, com o cálculo da relação cintura-quadril; medida da pressão arterial e dosagem do colesterol total, HDL-colesterol, LDL-colesterol, triglicérides, glicemia; hemograma completo e eletrocardiograma foram realizados em colaboração com o Projeto Estudo Longitudinal da Saúde do Adulto ELSA - Brasil, no Hospital Universitário da Universidade de São Paulo - HU-USP. Para a coleta de material foi solicitado que os voluntários permanecessem em jejum por 12 horas até a realização da bateria de exames, com início recomendado entre $6 \mathrm{~h}$ e $8 \mathrm{~h}$ da manhã.

Quadro 2. Relação IMC e Risco de doença

\begin{tabular}{ccc}
\hline $\mathbf{I M C}\left(\mathbf{K g} / \mathbf{m}^{\mathbf{2}}\right)$ & Classificação & Risco de doença \\
\hline$<18,5$ & Baixo Peso & Desnutrição \\
$18,5-24,9$ & Normal & Ausente \\
$25,0-29,9$ & Pré-Obeso & Aumentado \\
$30,0-34,9$ & Obeso grau I & Moderado \\
$35,0-39,9$ & Obeso grau II & Grave \\
$\geq 40,0$ & Obeso grau III & Muito Grave \\
\hline
\end{tabular}

Quadro 3. Relação da Circunferência Abdominal e RCQ e Risco de Doença

\begin{tabular}{lcccc}
\hline Sexo & \multicolumn{2}{c}{ Risco aumentado } & \multicolumn{2}{c}{ Alto Risco } \\
\hline & Cintura & RCQ & Cintura & RCQ \\
Masculino & $\geq 94 \mathrm{~cm}$ & $>0,90$ & $\geq 102 \mathrm{~cm}$ & $>1,00$ \\
Feminino & $\geq 80 \mathrm{~cm}$ & $>0,75$ & $\geq 88 \mathrm{~cm}$ & $>0,85$ \\
\hline
\end{tabular}

“A combinação de massa corporal e distribuição de gordura é, provavelmente, a melhor opção para preencher a necessidade de uma avaliação clínica” (SBEM apud Molarius et al,2004). Diante disso, e com auxílio da equipe de profissionais do Estudo Longitudinal de Saúde do Adulto (ELSA-Brasil), que atua no Centro de Investigação de São Paulo, foram realizadas as medidas de antropometria para avaliação do estado nutricional, com foco na 
presença de sobrepeso e obesidade. A média do IMC e da circunferência da cintura foi classificada de acordo com os critérios definidos pela Organização Mundial - OMS, quadros 1 e 2.

Para se conhecer o Índice de Massa Corporal - IMC - é necessário coletar as medidas de altura e peso de cada um dos voluntários da pesquisa e calcular o IMC de acordo com a fórmula IMC $=\mathrm{Peso} /(\text { altura })^{2}$, expresso como $\mathrm{Kg} / \mathrm{m}^{2}$.

Já o RCQ é a razão entre a medida da cintura pelo quadril. Com essas medidas e tendo como referência os parâmetros indicados pela OMS, Quadro 3, sabe-se qual o real risco de doença para os indivíduos.

Em relação à pressão arterial, cada voluntário fez três medidas, sendo considerada a média das duas últimas como a pressão arterial do indivíduo examinado. Em se tratando de grupos que iniciam atividades tendo, em um deles, a exigência de uso corporal de forma enfática, como é o caso da prática cênica, e o outro, de interesse autobiográfico, de caráter mais intelectual e com pouco movimento físico, o conhecimento sobre a pressão arterial torna-se imprescindível para saber se o resultado poderia indicar níveis de hipertensão arterial acima do normal e assim planejar as práticas físicas de acordo com esses índices.

Segundo a publicação da V Diretrizes Brasileiras de Hipertensão Arterial (2006), na aferição da Pressão Arterial (mmHg) são necessárias as seguintes medidas:

- se a sistólica for < 130 e a diastólica < 85, é recomendável reavaliação em 1 ano e estimular mudanças no estilo de vida;

- se a sistólica estiver entre 130-139 e a diastólica entre 85-89, é recomendável reavaliação em 6 meses e insistir em mudanças no estilo de vida;

- se a sistólica medir entre 140-159 e a diastólica, 90-99, é recomendável confirmação em dois meses e considerar MAPA/MRPA;

- se a sistólica medir entre 160-179 e a diastólica 100-109, é recomendável confirmação em 1 mês e também considerar MAPA/MRPA e por fim;

- se a sistólica medir $\geq 180$ e a diastólica, $\geq 110$, é recomendável intervenção medicamentosa imediata ou reavaliação em 1 semana. 
Escala de Likert (1932)

Tem este nome por ter sido criada por Rensis Likert (1932-1981), em 1932. Ela é muito utilizada em questionários para obtenção de respostas psicométricas, sendo comumente utilizada para pesquisas de opinião. Nesta pesquisa, a Escala Likert foi empregada apenas no Questionário de Avaliação Final da Atividade, Grupo 2, onde cada pergunta foi elaborada com seis itens Likert, ou seja, seis itens possíveis de resposta.

A instrução dada aos voluntários para a obtenção das respostas foi a seguinte: “Após o término da atividade de artes cênicas Só com Experiência, como você avalia seu corpo hoje quanto a: postura, movimento, flexibilidade, atenção, memória, motivação, estado emocional, relacionamento com o grupo, relacionamento com a família, relacionamento com os amigos e saúde?". Para cada um desses itens foi estabelecido um valor que variou de 0 a 5 , que correspondia a: Não melhorou (0), Melhorou pouco (1), Teve razoável melhora (2), Teve boa melhora (3), Teve ótima melhora (4) e Teve excelente melhora (5), conforme Apêndice XIV, página 171.

A aplicação desse questionário ocorreu após a apresentação cênica aberta ao público. Ele foi aplicado uma semana depois dessa apresentação, em encontro especial destinado apenas a avaliar todo o processo de trabalho desenvolvido. Vale ressaltar que não havia sido possível aplicar esse mesmo questionário ao G1, pois, como ele encerrara suas atividades próximas às festividades de Natal e Ano Novo, seus integrantes alegaram estar voltados a outras atividades familiares já programadas anteriormente para esse período e por isso mesmo não encontrariam tempo disponível para um novo encontro no local da pesquisa e ou em outro local qualquer. O que está de acordo com o conteúdo do TCLE, assinado pelos voluntários e acatado pela equipe pesquisadora.

Para a composição final dos resultados da pesquisa, foram feitas as transcrições do Questionário de Avaliação Final da Atividade, da Entrevista em Vídeo, do Depoimento em Vídeo sobre a apresentação do espetáculo. O levantamento e disponibilização dos dados estatísticos da pesquisa quantitativa, integrantes desse texto, foram verificados, tabulados e analisados por profissional especializado em estatística, com atuação no Instituto de Ciências Biomédicas da USP: 
Os resultados referentes ao Gênero, Identificação Socioeconômica e Cultural, Atividades de Lazer, Percepção da Própria Saúde, Atividade Física e Percepção Motora, Percepção Cognitiva e Escala Likert estão expressos em frequência (número e porcentagem).

Os resultados referentes à Idade (anos), Altura (cm), Peso(Kg), Capacidade Funcional, Domínios (Físico, Psicológico, Social, Ambiental e Qualidade de Vida) e as Facetas (Funcionamento dos Sentidos, Autonomia, Atividades Passadas Presentes e Futuras, Participação Social, Morte e Morrer, Intimidade e Global) estão expressos em média e desvio padrão.

Empregou-se o Teste de Wilcoxon para comparar os valores iniciais e finais do Peso (Kg), Capacidade Funcional, Domínios e Facetas. O nível de significância adotado foi de 0,05. (ZAR, 1984).

\subsection{Dificuldades metodológicas}

Os estágios de adequações e formulações para o desenvolvimento desse estudo possibilitaram reconhecer os vários níveis de dificuldade para se realizar uma pesquisa de caráter interdisciplinar e praticamente inédita com humanos.

A começar pela adequação da metodologia aos critérios do comitê de ética com humanos, o Comitê de Ética do Hospital Universitário da USP, que, após várias intervenções, autorizou a pesquisa no dia 17 de junho de 2011. A data de aprovação da pesquisa pelo Comitê coincidiu com o término da atividade cênica com o grupo recrutado em março/2011. Houve, então, a necessidade de recrutar novos indivíduos e reiniciar o estudo.

Porém, algumas dúvidas surgiram quanto aos instrumentos mais adequados à metodologia a ser desenvolvida com a população idosa participante da pesquisa.

Foi a partir daí que houve a aproximação com a equipe de fisioterapia e reabilitação da Universidade Federal de São Paulo, atuante na instituição Lar São Francisco, coordenada por Renata Cereda, que indicou estudos e resultados disponíveis na literatura, inclusive de artigos escritos por integrantes de sua equipe, sobre a percepção de qualidade de vida por grupos de idosos, como foram os casos dos trabalhos "Fatores associados à qualidade de vida em idosos 
ativos", de Alexandre et al (2009) e "Brazilian version of the Berg balance scale", de Miyamoto et al (2004), bem como possibilitou o acompanhamento da aplicação prática dos testes The Six-Minute Walk, Timed Up and Go, e One-Leg Balance Test em indivíduos idosos pertencentes aos projetos clínicos da instituição. Outra colaboração muito importante para as pretensões e superação das incertezas metodológicas foi o estabelecimento de contatos e parcerias com as equipes do Projeto ELSA, Estudo Longitudinal de Saúde do Adulto,

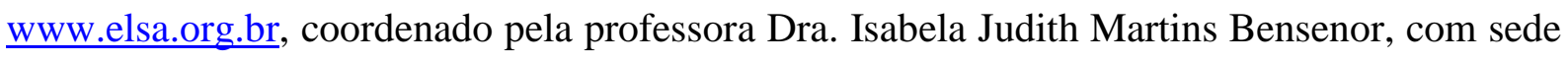
no Hospital Universitário da Universidade de São Paulo - HU-USP, e com o Instituto de Psiquiatria da Universidade de São Paulo - IPq-USP, através do PROTER - Projeto Terceira Idade, coordenado pelo professor Dr. Cássio M. C. Bottino, do Instituto de Psiquiatria do Hospital das Clínicas da FMUSP, que recomendou e disponibilizou um dos doutorandos da sua equipe para auxiliar a pesquisa. O estabelecimento dessas colaborações foi fundamental à dimensão do estudo proposto.

Aspectos mais delicados, porém inerentes ao estudo, como a administração da participação das pessoas que formaram os Grupos 1 e 2, os seres humanos, se fizeram presentes no decorrer da pesquisa. Foram inicialmente selecionados 27 idosos com o perfil adequado, porém apenas 17 pessoas, sendo 7 do G1 e 10 do G2, concluíram as atividades no período proposto. A desistência em continuar ou realizar determinada tarefa da atividade ocorreu por vários motivos:

1. Constrangimento emocional familiar: estar se "divertindo" enquanto seu companheiro, principalmente, fica em casa sem companhia;

2. Doenças na família, acompanhar o companheiro adoentado;

3. Ou mesmo por não ter superado durante a atividade algum sintoma de desequilíbrio emocional, como a depressão.

4. Dificuldades de efetivar os exames propostos na metodologia, em horário e local extraatividade.

Por fim, houve também a não disponibilidade dos voluntários do G1 para a segunda etapa da aplicação de alguns importantes instrumentos da pesquisa, como o Questionário de Avaliação Final (Escala Likert), assim como entrevistas e depoimentos finais, que não foram feitos no período previsto da atividade. Eles argumentaram que não queriam se comprometer com compromissos logo após a passagem de ano. 
No entanto, as atitudes dos voluntários estão de acordo com o conteúdo do Termo de Consentimento Livre e Esclarecido (TCLE), assinado por eles. 


\section{RESULTADOS}

Tabela 1. Perfil sociodemográfico dos voluntários, em gênero, idade, altura e peso, da $3^{\underline{a}}$ idade, pertencentes ao Grupo 1 e Grupo 2.

\begin{tabular}{|c|c|c|}
\hline & $\begin{array}{c}\text { Grupo } 1 \\
(n=7)\end{array}$ & $\begin{array}{c}\text { Grupo } 2 \\
(n=10)\end{array}$ \\
\hline 1. Feminino $^{1}$ & $7(100 \%)$ & $7(70 \%)$ \\
\hline Masculino $^{1}$ & 0 & $3(30 \%)$ \\
\hline 1. $\operatorname{Idade}^{2}$ (anos) & $69,9( \pm 8,6)$ & $66,6( \pm 4,9)$ \\
\hline 2. Altura $^{2}(\mathrm{~cm})$ & $155,4( \pm 6,3)$ & $159,8(\neq 6,8)$ \\
\hline $\begin{array}{l}\text { 3. } \text { Peso }^{2}(\mathrm{~kg}) \\
\text { Inicial } \\
\text { Final }\end{array}$ & $\begin{array}{l}66,0( \pm 8,4) \\
66,6( \pm 8,0)\end{array}$ & $\begin{array}{l}77,3( \pm 16,4) \\
77,2( \pm 16,5)\end{array}$ \\
\hline Inicial-Final (Kg) & $\begin{array}{c}-0,61( \pm 2,31) \\
(p=1,000)\end{array}$ & $\begin{array}{c}0,08( \pm 1,69) \\
(p=1,000)\end{array}$ \\
\hline
\end{tabular}

${ }^{1}$ Frequência; ${ }^{2}$ média \pm desvio padrão; $p$ : teste de Wilcoxon.

A Tabela 1 destaca a participação majoritária do sexo feminino nos dois grupos da pesquisa ( $100 \%$ no G1, atividade autobiográfica e literária e $70 \%$ no G2, treinamento cênico). A participação masculina se limita apenas ao grupo 2, com três (30\%) de seus integrantes pertencentes a este gênero. A média de idade dos participantes é muito próxima nos dois grupos $(69,9[ \pm 8,6]$ anos para o G1 e $66,6[ \pm 4,9]$ anos para o G2). Já em relação ao item "Altura", também apresenta percentuais muito próximos, porém com média maior para o grupo 2 (155,5 cm para o G1, e $159,8 \mathrm{~cm}$ para o G2). O último e terceiro item dessa Tabela, "Peso", com registro da média e desvio padrão entre início e final da atividade, em Kg, mostra a variação entre esses dois momentos, que correspondeu ao período de desenvolvimento da atividade, 6 meses, e apresenta relativa alteração nos resultados, com médias de $-0,61( \pm 2,31)$ para o G1, e 0,08 $( \pm 1,69)$ para o $G 2$, sem, no entanto, serem significantes $(p=1,000)$. 
Tabela 2. Perfil sociodemográfico: identificação socioeconômica e cultural dos voluntários da $3^{\underline{a}}$ idade, pertencentes ao Grupo 1 e Grupo 2, expressa em frequência.

\begin{tabular}{|c|c|c|}
\hline & $\begin{array}{c}\text { Grupo } 1 \\
(n=7)\end{array}$ & $\begin{array}{c}\text { Grupo } 2 \\
(n=10)\end{array}$ \\
\hline \multicolumn{3}{|l|}{ 1. Local de nascimento } \\
\hline Estado de São Paulo & $5(71 \%)$ & $4(40 \%)$ \\
\hline Outro Estado Brasileiro & $2(29 \%)$ & $5(50 \%)$ \\
\hline Outro País & 0 & $1(10 \%)$ \\
\hline \multicolumn{3}{|l|}{ 2. Estado Civil } \\
\hline Solteiro (a) & $3(43 \%)$ & $2(20 \%)$ \\
\hline Casado (a) & $2(29 \%)$ & $4(40 \%)$ \\
\hline Separado (a) & 0 & $1(10 \%)$ \\
\hline Viúvo (a) & $2(29 \%)$ & $3(30 \%)$ \\
\hline \multicolumn{3}{|l|}{ 2. Escolaridade } \\
\hline Fundamental Incompleto & $1(14 \%)$ & $3(30 \%)$ \\
\hline Técnico Completo & $1(14 \%)$ & 0 \\
\hline Superior Completo & $5(71 \%)$ & $4(40 \%)$ \\
\hline Pós-Graduação & 0 & $3(30 \%)$ \\
\hline 3. Tempo de estudo (anos) & $13,7 \pm 4,9$ & $15,7 \pm 8,1$ \\
\hline \multicolumn{3}{|l|}{ 4. Renda (número salários mínimos) } \\
\hline $1-2$ & $0(0 \%)$ & $1(10 \%)$ \\
\hline $3-4$ & $1(14 \%)$ & $1(10 \%)$ \\
\hline $5-6$ & $4(57 \%)$ & $4(40 \%)$ \\
\hline $7-8$ & 0 & $2(20 \%)$ \\
\hline $9-10$ & $1(14 \%)$ & $2(20 \%)$ \\
\hline$>10$ & $1(14 \%)$ & 0 \\
\hline \multicolumn{3}{|l|}{ 5. Mora com alguém? } \\
\hline Esposo (a) & $2(29 \%)$ & $4(40 \%)$ \\
\hline Filho (a) & 0 & $3(30 \%)$ \\
\hline Pais & 0 & $1(10 \%)$ \\
\hline Sozinho (a) & $5(71 \%)$ & $2(20 \%)$ \\
\hline \multicolumn{3}{|l|}{ 6. Residência } \\
\hline Própria & $6(86 \%)$ & $7(70 \%)$ \\
\hline Familiar & 0 & $1(10 \%)$ \\
\hline Alugada & $1(14 \%)$ & $2(20 \%)$ \\
\hline \multicolumn{3}{|l|}{ 7. Ocupação Atual } \\
\hline Aposentado (a) & $6(86 \%)$ & $4(40 \%)$ \\
\hline Auxílio Doença & 0 & $2(20 \%)$ \\
\hline Pensionista & 0 & $1(10 \%)$ \\
\hline Dona de Casa & $1(14 \%)$ & $1(10 \%)$ \\
\hline Consultor (a) & 0 & $1(10 \%)$ \\
\hline Psicólogo (a) & 0 & $1(10 \%)$ \\
\hline
\end{tabular}

A Tabela 2 evidencia a variação em relação ao local de nascimento dos participantes da pesquisa, sendo que $71 \%$ dos participantes do G1 nasceram no estado de São Paulo e 29\%, 
em outros estados do Brasil; enquanto que, no G2, $40 \%$ nasceram em São Paulo, 50\% em outros estados e $10 \%$, são oriundos de outro país. O estado civil "Solteiro" apresenta maior percentual no G1, 43\%, e "casado" no G2, com 40\%, enquanto a viuvez verificada é de $29 \%$ (G1) e 30\% (G2). Já o item relacionado a pessoas separadas, ele é nulo no G1 (0\%) e mínimo no G2, com apenas uma pessoa inclusa (10\%). O item "escolaridade" apresentou percentuais praticamente idênticos em ambos os grupos para o nível superior completo (G1, 71\%, e G2, $70 \%$ ), no entanto, participantes do G2 disseram ter também pós-graduação (30\%). O tempo de estudo, em anos, para ambos os grupos mostra média de $13,7( \pm 4,9)$ no G1 e 15,7 $( \pm 8,1)$ no G2. Os percentuais apresentados mostram que os integrantes do G1 têm ganhos salariais com maior percentual para a faixa entre "5-6" salários, 57\% no G1 e 40\% no G2, porém apresenta indicadores para todas as faixas colocadas no item do questionário, faixas entre 1-2 e > 10 salários mínimos. O item a seguir, "Mora com alguém”, apresenta os percentuais maiores para as categorias "Sozinho" com 71\% (G1) e "Esposo" 40\% (G2), mas destaca também que todas as categorias foram contempladas pelo G2, com "Filho", "Pais" e "Sozinho", tendo os percentuais de 30\%,10\% e 20\%, respectivamente, e apenas mais uma no G1, "Esposo", com 29\%. No item "Residência", a categoria "Própria" possui percentuais de $86 \%$ para o G1, e $70 \%$ para o G2, enquanto a "Familiar" é 0\% para o G1 e 10\% para G2; "Alugada", 14\% para o G1 e 20\% para o G2. Por último, no item "Ocupação atual”, as categorias "Aposentado" e "Dona de casa" têm os percentuais de $86 \%$ e 14\%, respectivamente no G1, enquanto que no G2 as categorias se configuraram da seguinte forma: "Auxílio doença”, 20\%; "Pensionista", 10\%; "Dona de casa", 10\%; "Consultor", 10\%; e "Psicólogo", 10\%, e "Aposentado" , 40\%. 
Tabela 3. Perfil sociodemográfico: atividades de lazer dos voluntários da $3^{\underline{a}}$ idade pertencentes ao Grupo 1 e Grupo 2, expressas em frequência.

\begin{tabular}{|c|c|c|}
\hline & $\begin{array}{c}\text { Grupo } 1 \\
(n=7)\end{array}$ & $\begin{array}{c}\text { Grupo } 2 \\
(n=10)\end{array}$ \\
\hline \multicolumn{3}{|l|}{ 1. Realiza atividades de lazer? } \\
\hline Sim & $6(86 \%)$ & $10(100 \%)$ \\
\hline Não & $1(14 \%)$ & 0 \\
\hline 2. № de Atividades de lazer realizadas & $5,6 \pm 3,2$ & $5,3 \pm 2,6$ \\
\hline \multicolumn{3}{|l|}{ 3. Atividades de lazer realizadas } \\
\hline Atividades Manuais & $2(29 \%)$ & $3(30 \%)$ \\
\hline Bingo & $1(14 \%)$ & 0 \\
\hline Caminhada & $2(29 \%)$ & $5(50 \%)$ \\
\hline Cartas & 0 & $3(30 \%)$ \\
\hline Cinema & $5(71 \%)$ & $7(70 \%)$ \\
\hline Computador & $4(57 \%)$ & $7(70 \%)$ \\
\hline Dança Espanhola & 0 & $1(10 \%)$ \\
\hline Igreja & 0 & $1(10 \%)$ \\
\hline Leitura & $5(71 \%)$ & $7(70 \%)$ \\
\hline Música & $4(57 \%)$ & $7(70 \%)$ \\
\hline Natação & $1(14 \%)$ & 0 \\
\hline Palavras Cruzadas & $2(29 \%)$ & $4(40 \%)$ \\
\hline Teatro & 0 & $1(10 \%)$ \\
\hline Televisão & $3(43 \%)$ & $7(70 \%)$ \\
\hline Viagens & $3(43 \%$ & $1(10 \%)$ \\
\hline \multicolumn{3}{|l|}{ 4. Tem acesso a: } \\
\hline Rádio & $7(100 \%)$ & $10(100 \%)$ \\
\hline $\mathrm{TV}$ & $7(100 \%)$ & $10(100 \%)$ \\
\hline Jornal/Revista/Livro & $5(71 \%)$ & $9(90 \%)$ \\
\hline Computador & $5(71 \%)$ & $9(90 \%)$ \\
\hline
\end{tabular}

A Tabela 3, com dados sobre as atividades de lazer praticadas pelos voluntários da pesquisa, mostra que o item "Realiza atividade de lazer" alcançou percentual de $86 \%$ no G1, e 100\% no G2 para a resposta "Sim", enquanto que a resposta dada à enquete seguinte, "Número de atividades de lazer realizadas", teve média de 5,6 $( \pm 3,2)$ atividades realizadas pelos voluntários do G1, e, no G2, média de 5,3 $( \pm 2,6)$ atividades. Das atividades escolhidas pelos voluntários do G1, destacam-se Cinema (71\%), Computador (57\%), Leitura (71\%) e Música (57\%); e Caminhada (50\%), Cinema (70\%), Computador (70\%), Leitura (70\%) e Música (70\%) pelos integrantes do G2. O último item dessa Tabela, “Tem acesso a”, indica que todas as categorias registraram índices acima de 70\%, em ambos os grupos. 
Tabela 4. Perfil sociodemográfico: percepção da própria saúde pelos voluntários da $3^{\underline{a}}$ idade, pertencentes ao Grupo 1 e Grupo 2, expressa em frequência.

\begin{tabular}{lcc}
\hline & $\begin{array}{c}\text { Grupo 1 } \\
(\mathbf{n = 7})\end{array}$ & $\begin{array}{c}\text { Grupo 2 } \\
(\mathbf{n = 1 0})\end{array}$ \\
\hline $\begin{array}{l}\text { 1. Percepção de saúde } \\
\quad \text { Saudável }\end{array}$ & $10(100 \%)$ \\
$\quad$ Doente & $1(14 \%)$ & 0 \\
2. Faz uso de medicamentos? & & \\
$\quad$ Sim & $6(86 \%)$ & $8(80 \%)$ \\
$\quad$ Não & $1(14 \%)$ & $2(20 \%)$ \\
3. Sono noturno (horas) & $6,1 \pm 1,6$ & $7,7( \pm 0,6$ \\
4. Dorme durante o dia? & $2(29 \%)$ & $3(30 \%)$ \\
$\quad$ Sim & $5(71 \%)$ & $7(70 \%)$ \\
$\quad$ Não & & $7(70 \%)$ \\
5. Apresenta limitação física? & $6(86 \%)$ & $3(30 \%)$ \\
$\quad$ Sim & $1(14 \%)$ & \\
Não & & $5(50 \%)$ \\
6. Sente dor? & $3(43 \%)$ & $5(50 \%)$ \\
$\quad$ Sim & $4(57 \%)$ & \\
$\quad$ Não & & \\
\hline
\end{tabular}

Em relação à Tabela 4, que trata da percepção da saúde por parte dos participantes da pesquisa, apenas 14\% (G1) se consideraram "Doente", sendo que nesse mesmo grupo 86\% dos voluntários responderam ser "Saudável”. Já todos os integrantes do G2 afirmaram ser “Saudável". Entre aqueles que responderam fazer uso de medicamentos, 86\% são do G1 e 80\% do G2. Em relação ao "Sono noturno", os voluntários afirmaram dormir em média 6,1 horas (G1) e 7,7 horas (G2); e, ao sono durante o dia, 71\% (G1) e 70\% (G2) são categóricos em dizer "Não". Dos que responderam "Sim" quanto a apresentar limitação física, 86\% são do G1 e 70\% do G2. As respostas "Sim" para o item "Sente dor?" apresentaram índices percentuais muito próximos entres os grupos, de $43 \%$ (G1) e $50 \%$ (G2). 
Tabela 5. Perfil sociodemográfico: atividade física e percepção motora dos voluntários da $3^{\text {a }}$ idade, pertencentes ao Grupo 1 e Grupo 2, expressas em frequência.

\begin{tabular}{ccc}
\hline 1. Realiza alguma atividade física? & $\begin{array}{c}\text { Grupo 1 } \\
(\mathbf{n = 7})\end{array}$ & $\begin{array}{c}\text { Grupo 2 } \\
(\mathbf{n = 1 0})\end{array}$ \\
Sim & $5(71 \%)$ & $9(90 \%)$ \\
Não & $2(29 \%)$ & $1(10 \%)$ \\
2. Quais? & & \\
Alongamento & $1(14 \%)$ & $2(20 \%)$ \\
Caminhada & $4(57 \%)$ & $5(50 \%)$ \\
Exercícios & 0 & $1(10 \%)$ \\
Hidroginástica & $2(29 \%)$ & 0 \\
Musculação & 0 & $1(10 \%)$ \\
Natação & $1(14 \%)$ & $1(10 \%)$ \\
Tai Chi Chuan & 0 & $1(10 \%)$ \\
3. Mobilidade física atual & & $1(10 \%)$ \\
Ótima & 0 & $4(40 \%)$ \\
Boa & $3(43 \%)$ & $5(50 \%)$ \\
Regular & $3(43 \%)$ & 0 \\
Ruim & $1(14 \%)$ & \\
Sim & & $9(90 \%)$ \\
Não & $6(86 \%)$ & $1(10 \%)$ \\
\hline
\end{tabular}

Quanto às respostas para a prática de atividades físicas e percepção motora, a Tabela 5 mostra que, no item "Realiza alguma atividade física", o "Sim" obteve os percentuais de 71\% (G1) e 90\% (G2). À pergunta "Quais" são essas atividades, o maior percentual foi dado a caminhada (40\% no G1 e 50\%, no G2). Na sequência, questionados sobre sua "Mobilidade física atual", os voluntários responderam ser Regular (43\%) e Boa (43\%) no G1 e Regular (50\%) e Boa (40\%) no G2. Apenas 10\% afirmam ser "Ótima" sua mobilidade atual no G2 e 14\% optam pelo "Ruim" no G1. À pergunta seguinte, sobre se a "Mobilidade mudou com a idade", $86 \%$ dos participantes do G1 confirmam que "Sim", enquanto que no G2 esse percentual para o mesmo "Sim" foi de $90 \%$. 
Tabela 6: Perfil sociodemográfico: percepção cognitiva dos voluntários da $3^{\text {a }}$ idade, pertencentes ao Grupo 1 e Grupo 2, expressa em frequência.

\begin{tabular}{lcc}
\hline Memória atual & $\begin{array}{c}\text { Grupo 1 } \\
(\mathbf{n = 7})\end{array}$ & $\begin{array}{c}\text { Grupo 2 } \\
(\mathbf{n = 1 0})\end{array}$ \\
\hline $\begin{array}{l}\text { Ótima } \\
\text { Boa }\end{array}$ & 0 & $2(20 \%)$ \\
$\quad$ Regular & $3(43 \%)$ & $4(40 \%)$ \\
Ruim & $3(43 \%)$ & $4(40 \%)$ \\
2. Memória mudou com a idade? & $1(14 \%)$ & 0 \\
Sim & & \\
Não & $3(43 \%)$ & $7(70 \%)$ \\
3. Atenção atual & $4(57 \%)$ & $3(30 \%)$ \\
$\quad$ Ótima & & $2(20 \%)$ \\
Boa & $1(14 \%)$ & $3(30 \%)$ \\
Regular & $3(43 \%)$ & $5(50 \%)$ \\
Ruim & $1(14 \%)$ & 0 \\
4. Atenção mudou com a idade? & $2(29 \%)$ & $5(50 \%)$ \\
Sim & & $5(50 \%)$ \\
$\quad$ Não & $6(86 \%)$ & \\
\hline
\end{tabular}

Na Tabela 6, que apresenta os dados sobre a percepção cognitiva dos voluntários, no item que inquire sobre como está a "Memória atual", 43\% dos participantes do G1 a consideraram ser "Boa"; outros 43\% indicaram ser "Regular" e 14\%, "Ruim". No G2, os voluntários atribuíram 40\% tanto para "Boa" como para "Regular", sendo que 20\% a consideraram “Ótima”. Para a pergunta posterior, sobre se a "Memória mudou com a idade?", $57 \%$ dos voluntários do G1 afirmaram que "Não", enquanto que 70\% dos participantes do G2 afirmaram que "Sim". As respostas em relação à "Atenção atual" indicaram como percentuais: no G1, 14\% para "Ótimo" e "Regular", 43\% para "Boa" e 29\% para "Ruim"; no G2, 20\% para "Ótima", 30\% para "Boa” e 50\%, para "Regular". O último item da Tabela 6, se a "Atenção mudou com a idade?", $86 \%$ dos integrantes do G1 afirmaram que "Sim", enquanto que no G2 o percentual foi 50\%, tanto para "Sim" como para "Não". 
Tabela 7: Capacidade funcional dos voluntários da $3^{\text {a }}$ idade, pertencentes ao Grupo 1 e Grupo 2, expressos como média \pm desvio padrão.

\begin{tabular}{lcc}
\hline & Grupo 1(n=7) & Grupo 2(n=10) \\
\hline 1.Timed Up and Go Test (seg) & $9,7 \pm 2,0$ & $9,7 \pm 1,5$ \\
Inicial & $9,8 \pm 2,2$ & $9,1 \pm 1,5$ \\
Final & $-0,07 \pm 0,84$ & $0,59 \pm 1,14$ \\
& $(\mathrm{p}=0,800)$ & $(\mathrm{p}=0,262)$ \\
Inicial-Final & & \\
& & $11,4 \pm 2,5$ \\
2.Timed Up and Go Test- Dupla Tarefa (seg) & $10,4 \pm 3,0$ & $10,5 \pm 2,3$ \\
Inicial & $10,2 \pm 1,9$ & $0,91 \pm 1,86$ \\
Final & $0,20 \pm 1,38$ & $(\mathrm{p}=0,185)$ \\
& $(\mathrm{p}=0,933)$ & \\
Inicial-Final & & $420,0 \pm 91,6$ \\
& & $477,9 \pm 94,0$ \\
3. Six-minute Walk Test (m) & $392,6 \pm 51,8$ & $(\mathrm{p}=0,006)$ \\
Inicial & $409,1 \pm 26,1$ & \\
Final & $16,57 \pm 31,92$ & $(\mathrm{p}=0,067)$ \\
Final-Inicial & $(\mathrm{p}=0,271)$ & \\
& & $9,65 \pm 10,11$ \\
4. One-Leg Balance Test (seg) & & $12,62 \pm 8,59$ \\
Inicial & $9,18 \pm 5,29$ & $2,97 \pm 3,83$ \\
Final & $9,16 \pm 7,21$ & \\
Final-Inicial & $-0,02 \pm 5,16$ & \\
& $(\mathrm{p}=0,353)$ & \\
\hline
\end{tabular}

p: teste de Wilcoxon.

Conforme mostra a Tabela 7, no primeiro teste, Timed Up and Go, sem dupla tarefa, os voluntários do G1, antes do treinamento, em média, cumpriram o percurso em $9,7( \pm 2,0)$ segundos, e, após treinamento, a média para a performance foi de $9,8( \pm 2,2)$ segundos, com variação negativa de $-0,07$ segundos $(\mathrm{p}=0,800)$. O G2, nessa mesma etapa anterior ao treinamento, fez o mesmo percurso com a média de $9,7( \pm 1,5)$ segundos e, após o treinamento, a média registrou $9,1( \pm 1,5)$ segundos, ou seja, ela apresenta diminuição de tempo percorrido em $0,59( \pm 1,14)$ segundos $(\mathrm{p}=0,262)$.

No teste com execução de tarefa paralela, o "Timed Up and Go Test com Dupla Tarefa", se observa na Tabela 7 que o G1, inicialmente, executou o percurso com a média de 10,4 $( \pm 3,0)$ segundos e, que no teste pós-treinamento, atingiu a marca de 10,2 $( \pm 1,9)$ segundos para o mesmo percurso, ou seja, diminuiu em $0,20( \pm 1,38)$ segundos $(\mathrm{p}=0,933)$ a sua média. $\mathrm{O} G 2$, nesse mesmo teste com dupla tarefa, também apresenta diminuição de tempo em sua média de 
execução, 0,91 $( \pm 1,86)$ segundos, como mostram os escores entre as fases Inicial e Final, 11,4 $( \pm 2,5)$ segundos e 10,5 $( \pm 2,3)$ segundos, respectivamente $(\mathrm{p}=0,185)$.

Tabela 7 mostra também que, na Fase Inicial, a média do G1 para a tarefa em marcha durante 6 minutos, The Six-minute Walk Test, registrou a distância de 392,6 m ( \pm 51,8 m); já na fase seguinte, a final, após o término da intervenção oferecida aos voluntários, há aumento da distância percorrida de 16,57 m ( $\pm 31,92 \mathrm{~m})$ para os mesmos 6 minutos em marcha, ou seja, atingiu no mesmo tempo estabelecido para a Fase Inicial a distância de 409,1 m ( $\pm 26,1$ m), p=0,271. Já os voluntários do G2, em seis minutos de caminhada, percorreram, em média, a distância de 420,0 m ( $\pm 91,6$ m) na Fase Inicial e 477,90 m ( \pm 94,0 m) na Final, ou seja, uma variação positiva de $57,90 \mathrm{~m}$ e estatisticamente significante $(\mathrm{p}=0,006)$.

A Tabela 7 ainda apresenta On-Leg Balance Test para os dois grupos pesquisados. Na Fase Inicial, o G1 registrou, em média, o tempo de 9,18 s ( $\pm 5,29$ s) e na Final, 9,16s ( $\pm 7,21 \mathrm{~s})$, uma diferença negativa entre os tempos de $-0,02 \mathrm{~s}( \pm 5,16 \mathrm{~s})$; enquanto que no G2 a performance de seus voluntários na Fase Inicial obteve o tempo médio de 9,65 s ( $\pm 10,11 \mathrm{~s})$ e, na Final, de 12,62 s ( $\pm 8,59 \mathrm{~s})$, obtendo assim a diferença positiva de 2,97 s ( \pm 3,83 s) em permanecer em equilíbrio sobre uma perna. No entanto, os resultados não foram estatisticamente significantes. 
Tabela 8. Média e desvio padrão dos valores referentes aos Domínios Físico, Psicológico, Social, Meio Ambiente e Qualidade de Vida, avaliados pelo WHOQOL-Bref, dos voluntários da $3^{\mathbf{a}}$ idade, integrantes do Grupo 1

\begin{tabular}{lccc}
\hline Domínio & Inicial & Final & $\mathrm{p}$ \\
\hline Físico & $67,35 \pm 22,06$ & $69,90 \pm 21,12$ & 0,414 \\
Psicológico & $72,02 \pm 13,33$ & $70,24 \pm 11,64$ & 0,607 \\
Social & $63,10 \pm 16,57$ & $64,29 \pm 14,20$ & 0,705 \\
Meio Ambiente & $62,50 \pm 17,02$ & $63,40 \pm 16,51$ & 0,480 \\
Qualidade de Vida & $66,24 \pm 14,74$ & $66,95 \pm 13,04$ & 0,735 \\
\hline
\end{tabular}

p: teste de Wilcoxon.

A Tabela 8 apresenta os valores das respostas dadas pelos voluntários do G1 contidas no questionário de avaliação da qualidade de vida das pessoas, o WHOQOL-Bref.

O primeiro domínio da Tabela, o Domínio Físico (DF), foi o que teve maior variação (positiva) entre todos os domínios avaliados pelo G1; inicialmente, antes da atividade desenvolvida, ele apresentou a pontuação de 67,35 $( \pm 22,06)$ e, no pós-treinamento, de 69,90 $( \pm 21,12)$. Outras variações positivas também estão presentes nas avaliações dos domínios, como no Domínio Social (DS), ou Relações Sociais, acentuando a pontuação de 63,10 $( \pm 16,57)$ na primeira aplicação do questionário, e $64,29( \pm 14,20)$ no pós-treinamento; no Domínio Meio Ambiente (DMA), pontuação de 62,50 ( $( \pm 17,02)$ no início da atividade e 63,40 $( \pm 16,51)$ no final. Já a avaliação do Domínio Qualidade de Vida $(Q V)$ apresentou pontuação inicial de 66,24 ( \pm 14,74), e de 66,95 ( \pm 13,04) no pós-treinamento. O Domínio Psicológico (DP) foi o único, na Tabela 9, a apresentar variação negativa, obtendo pontuação de 72,02 $( \pm 13,33)$ na fase Inicial e, na Final, de 70,24 $( \pm 11,64)$. No entanto, nenhuma das diferenças apresentadas nos domínios evidenciou resultado estatisticamente significante para a pesquisa. 
Tabela 9. Média e desvio padrão dos valores referentes aos domínios Físico, Psicológico Social, Meio Ambiente e Qualidade de Vida, avaliados pelo WHOQOL Bref, dos voluntários da $3^{\mathrm{a}}$ idade, integrantes do Grupo 2.

\begin{tabular}{lccc}
\hline Domínio & Inicial & Final & p \\
\hline Físico (DF) & $72,50 \pm 12,93$ & $71,43 \pm 16,75$ & 0,778 \\
Psicológico (DP) & $72,50 \pm 16,34$ & $75,83 \pm 16,05$ & 0,136 \\
Social (DS) & $72,50 \pm 19,66$ & $69,17 \pm 28,34$ & 0,527 \\
Meio Ambiente (DMA) & $66,57 \pm 8,84$ & $68,13 \pm 7,19$ & 0,435 \\
Qualidade de Vida (QV) & $71,02 \pm 11,78$ & $71,14 \pm 14,97$ & 0,919 \\
\hline
\end{tabular}

p: teste de Wilcoxon.

A Tabela 9 apresenta a pontuação obtida pelo WHOQOL-Bref, relativa aos participantes do G2, cujo treinamento enfatizou a atividade cênica. Ela mostra que os domínios Físico, Psicológico e Social apresentam a mesma pontuação na fase Inicial: 72,50 $( \pm 12,93, \pm 16,34, \pm 19,66$, respectivamente). Enquanto que, na fase Final, pós-treinamento, evidenciam-se alterações em suas pontuações: 71,43 $( \pm 16,75), 75,83( \pm 16,05)$ e 69,17 $( \pm 28,34)$, respectivamente, sendo a variação do Domínio Psicológico positiva e a dos outros dois domínios negativas. O Domínio Meio Ambiente apresentou variação positiva: no início da pesquisa foi de $66,57( \pm 8,84)$, e de $68,13( \pm 7,19)$ na fase Final. Da mesma forma o Domínio Qualidade de Vida, com pontuação inicial de $71,02( \pm 11,78)$ e final de 71,14 $( \pm 14,97)$. Na observação dos resultados na Tabela 9 , não foi detectada nenhuma diferença estatisticamente significante. 
A seguir, a Figura 11 apresenta avaliação individual dos voluntários do grupo G1 pelo instrumento WHOQOL-Bref.
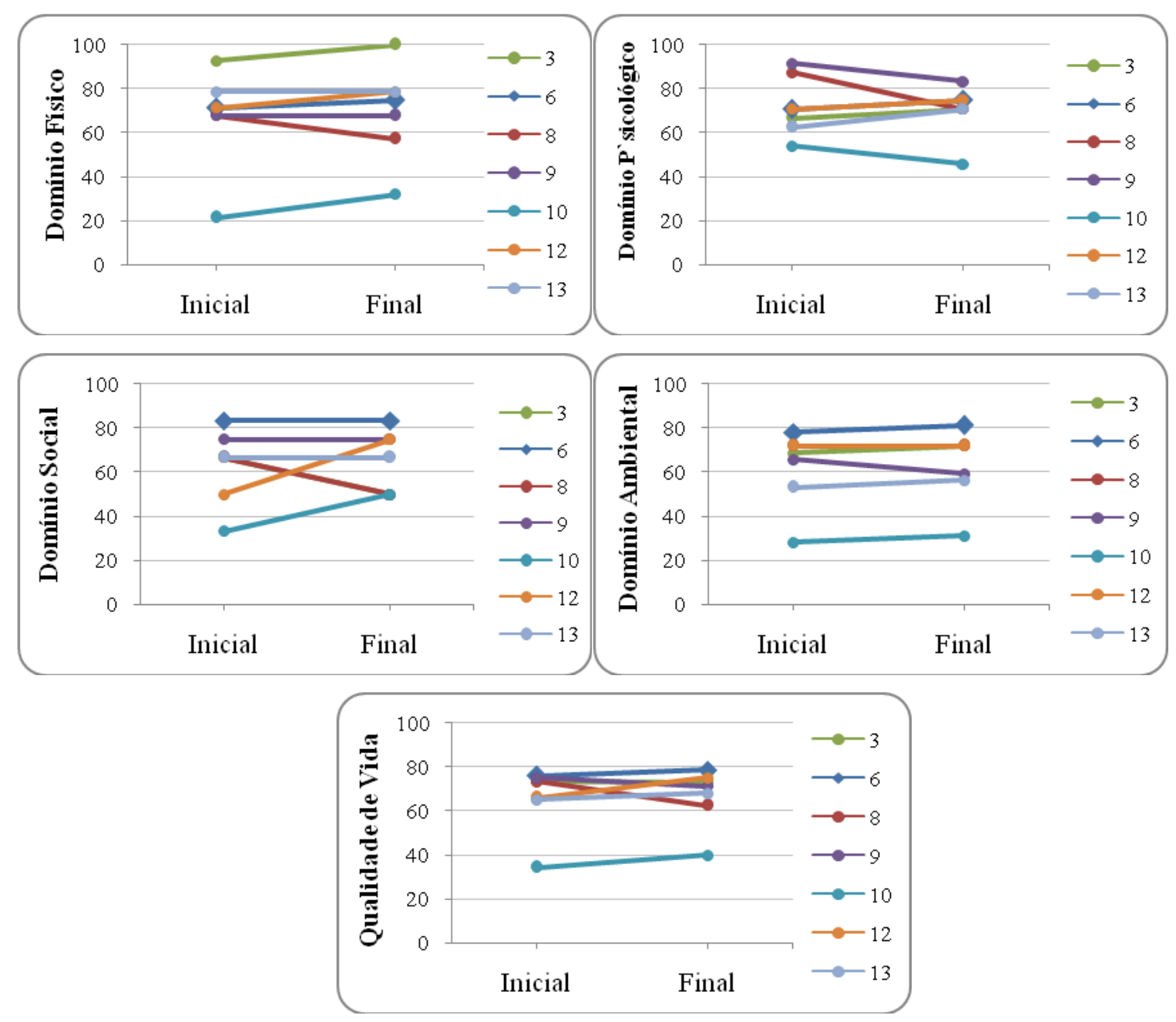

Figura 11. Valores individuais, inicial e final, dos domínios Físico, Psicológico, Social, Ambiental e Qualidade de Vida dos voluntários da 3 ${ }^{\underline{a}}$ idade, integrantes do Grupo 1, avaliados pelo WHOQOL-Bref.

A Figura 11, com os valores individuais dos voluntários do G1, evidencia a avaliação dos domínios na primeira etapa da pesquisa, na sua maioria, por possuir pontuação superior a 50, como mostram os domínios Físico (DF), Social (DS) e Ambiental (DA), com 6 voluntários (3, 6, 8, 9, 12 e 13), e o Domínio Psicológico (DP), incluindo todos os voluntários nessa pontuação. Essa mesma percepção sobre os domínios avaliados pelos participantes permanece na segunda etapa da pesquisa (Final), a pontuação acima de 50 (em uma escala de 0 a 100 pontos), independente das variações ocorridas tanto positiva como negativa. Há 
também, de forma evidente, a indicação de apenas um voluntário, 10, se autoavaliar abaixo desse valor nas duas etapas aferidas. Já o voluntário 8 apresenta variação negativa em todos os domínios, porém sua pontuação nunca ficou abaixo de 50 pontos, ficando assim muito próxima da pontuação indicada pelos participantes no Domínio Qualidade de Vida (QV), que registrou pequena variação positiva entre a primeira e segunda etapa da pesquisa, inicial 66,24 $( \pm 14,74)$, e final, 66,95 $( \pm 13,04)$. As variações apresentadas pelos domínios na Figura 11 não evidenciam resultado estatisticamente significante para a pesquisa. 
A Figura 12 apresenta avaliação individual dos voluntários do grupo G2 pelo instrumento WHOQOL-Bref.

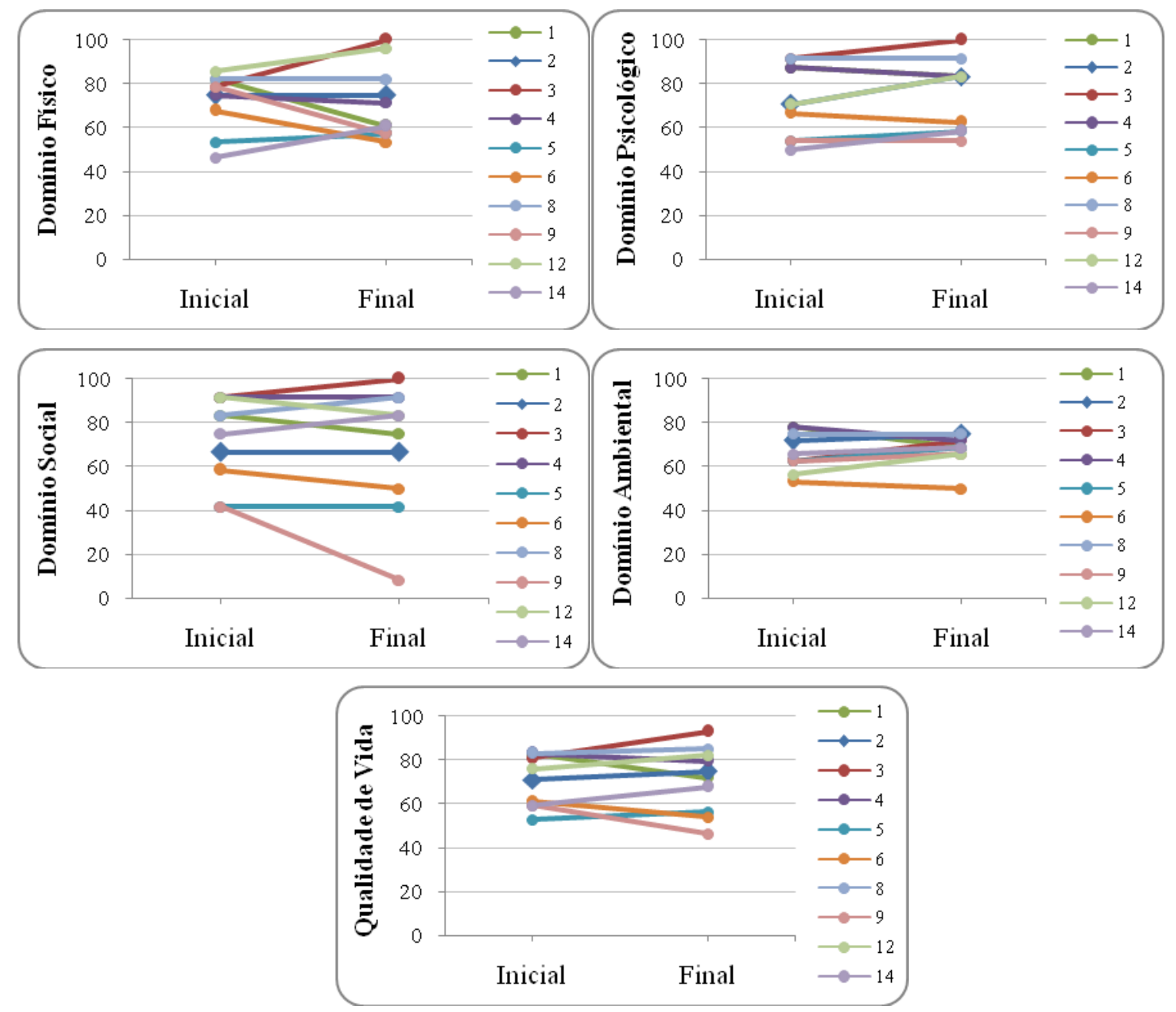

Figura 12. Valores individuais, inicial e final, dos domínios Físico, Psicológico, Social, Ambiental e Qualidade de Vida dos voluntários da $3^{\underline{a}}$ idade, integrantes do Grupo 2, avaliados pelo WHOQOL-Bref.

A Figura 12 evidencia similaridade na quantidade de variações dos valores obtidos em relação aos domínios avaliados na segunda etapa da pesquisa (Final), tanto para aqueles que sugerem melhor percepção de qualidade de vida (valores crescentes) como o contrário (valores decrescentes), ou mesmo aqueles que se mantiveram inalterados, ou seja: no Domínio Físico (DF), quatro voluntários (3, 5, 12 e 14) agregaram pontuação maior a sua avaliação, quatro outros $(1,4,6$, e 9) diminuíram sua pontuação e os voluntários 2 e 8 permaneceram com a mesma pontuação da fase inicial; no Domínio Psicológico (DP), há uma pequena mudança em relação ao DF, cinco voluntários $(2,3,5,12$ e 14) indicaram pontuação maior em sua avaliação, enquanto três voluntários (1, 4 e 6) optaram por avaliarem sua 
percepção sobre esse domínio com pontuação menor, e dois (voluntários 8 e 9) permaneceram com pontuação inalterada; no Domínio Social (DS), há três voluntários (voluntários 2, 4 e 5) que indicaram a mesma pontuação nas duas etapas, três voluntários $(3,8$ e 14) que avaliaram melhor sua percepção sobre esse domínio e outros quatro voluntários (1, 6, 9 e 12) indicaram pontuação abaixo daquelas obtidas na primeira etapa. No Domínio Ambiental (DA), na segunda etapa de aplicação do questionário, três voluntários ( 1,4 e 6) avaliaram negativamente esse domínio após o treinamento; seis voluntários $(2,3,5,9,12$ e 14) avaliaram positivamente e apenas um voluntário (8) permaneceu com a mesma pontuação da primeira fase.

A Figura 12 também enfatiza que seis indivíduos (voluntários 2, 3, 5, 8, 12 e 14) avaliaram sua percepção sobre o Domínio Qualidade de Vida com pontuação acima de 70, e quatro (voluntários 1, 4, 6 e 9), entre 45 e 70. Chamam atenção as pontuações apresentadas pelos voluntários 3 (93) e 9 (46). Essa diferença é vista com clareza na Figura 12: enquanto a avaliação do voluntário 3 é marcadamente crescente, alcançando quase o valor máximo de 100, o voluntário 9 apresenta situação oposta, com valor acentuadamente decrescente, com pontuação próxima de 40.

Tabela 10. Média e desvio padrão dos valores das facetas Funcionamento dos Sentidos, Autonomia, Atividades Passadas, Presentes e Futuras, Participação Social, Morte e Morrer, Intimidade e Global avaliadas pelo WHOQOL-OLD, obtidos a partir das respostas fornecidas pelos voluntários da $3^{\underline{a}}$ idade integrantes do Grupo 1.

\begin{tabular}{lccc}
\hline Faceta & Inicial & Final & p \\
\hline Funcionamento dos Sentidos & $75,89 \pm 14,17$ & $73,21 \pm 21,26$ & 0,595 \\
Autonomia & $58,93 \pm 27,68$ & $58,93 \pm 22,49$ & 0,891 \\
Atividades Passadas, Presentes e & $66,07 \pm 12,43$ & $65,18 \pm 15,67$ & 0,783 \\
$\quad$ Futuras & $66,07 \pm 14,37$ & $68,75 \pm 18,75$ & 0,435 \\
Participação Social & $66,96 \pm 22,16$ & $73,21 \pm 10,02$ & 0,416 \\
Morte e Morrer & $70,54 \pm 5,94$ & $61,61 \pm 22,37$ & 0,336 \\
Intimidade & $67,41 \pm 7,53$ & $66,82 \pm 14,46$ & 0,735 \\
Global & & &
\end{tabular}

$\mathrm{p}$ : teste de Wilcoxon.

A Tabela 10 mostra os resultados da avaliação conferida ao WHOQOL-OLD pelos voluntários pertencentes ao G1, que desenvolveram o treinamento baseado na atividade 
autobiográfica e literária. Nela, a Faceta Funcionamento dos Sentidos apresentou ligeira diminuição de pontuação entre as fases de aplicação do questionário: $75,89( \pm 14,17)$ inicialmente, e 73,21 $( \pm 21,26)$ na segunda etapa de aplicação do questionário (Final). A avaliação da Faceta Participação Social apresentou valor positivo entre as fases de aplicação do questionário, Inicial de 66,07 $( \pm 14,37)$ e Final de 68,75 $( \pm 18,75)$. A Faceta Autonomia mostrou estabilidade na avaliação dos participantes, nas duas fases a pontuação foi a mesma, apenas o desvio padrão foi que variou (Inicial 58,93 [ $\pm 27,98]$ e Final 58,93 [ $\pm 22,49]$ ). Já a Faceta Atividades Passadas, Presentes e Futuras, indicou números com resultado negativo de uma fase para a outra, 66,07 $( \pm 12,43)$ na fase Inicial e $65,18( \pm 15,67)$ na Final. As facetas seguintes, Morte e Morrer, têm pontuação positiva entre as fases: Inicial $66,96( \pm 22,16)$ e Final 73,21 ( $\pm 10,02)$; Intimidade, pontuação negativa, Inicial de 70,54 $( \pm 5,94)$ e Final de $61,61( \pm 22,37)$; e por fim, a Global, que apresentou resultado negativo com valor Inicial de $67,41( \pm 7,53)$ e Final de 66,82 $( \pm 14,46)$. Em todos os resultados indicados na Tabela 10, não houve detecção de diferença estatisticamente significante.

Tabela 11. Média e desvio padrão dos valores das facetas Funcionamento dos Sentidos, Autonomia, Atividades Passadas, Presentes e Futuras, Participação Social, Morte e Morrer, Intimidade e Global avaliadas pelo WHOQOL-OLD, obtidos a partir das respostas fornecidas pelos voluntários da $3^{\underline{a}}$ idade integrantes do Grupo 2.

\begin{tabular}{lccc}
\hline Faceta & Inicial & Final & p \\
\hline Funcionamento dos Sentidos & $80,00 \pm 22,40$ & $76,88 \pm 18,88$ & 0,305 \\
Autonomia & $71,25 \pm 12,91$ & $71,88 \pm 18,22$ & 0,914 \\
Atividades Passadas, Presentes e & $75,00 \pm 12,50$ & $77,50 \pm 17,97$ & 0,573 \\
$\quad$ Futuras & $66,25 \pm 10,70$ & $72,50 \pm 19,81$ & 0,232 \\
Participação Social & $71,88 \pm 20,25$ & $66,88 \pm 13,19$ & 0,282 \\
Morte e Morrer & $70,00 \pm 23,16$ & $65,63 \pm 35,99$ & 0,863 \\
Intimidade & $72,40 \pm 9,29$ & $71,88 \pm 16,08$ & 0,798 \\
Global & & & \\
\hline
\end{tabular}

p: teste de Wilcoxon.

A Tabela 11 é relativa às questões do WHOQOL-OLD respondidas pelos voluntários do G2, ou seja, os participantes do treinamento em artes cênicas. Ela evidencia um quadro estável, com pequena variação negativa na faceta Global, que inicialmente tinha a pontuação de $72,40( \pm 9,29)$ e no final $71,88( \pm 16,08)$. 
É possível observar na Tabela 11 pontuação inalterada para a avaliação da Faceta Autonomia (inicial de 71,25 [ $\pm 12,91]$, final de $71,88[ \pm 18,22]$ ), assim como pequena variação negativa nas facetas Funcionamento dos Sentidos (fase Inicial, 80,00 [ $\pm 22,40]$ e $76,88[ \pm 18,88]$, Final); Morte e Morrer (inicial de 71,88 [ $\pm 20,25]$ e final de $66,88[ \pm 13,19]$ ); e

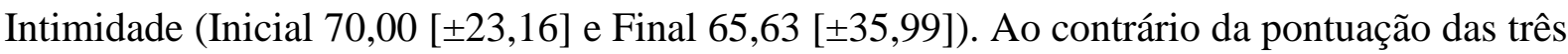
facetas anteriores, as facetas Atividades Passadas, Presentes e Futuras (Inicial de 75,00 $[ \pm 12,50]$ e final de 77,50 [ $[17,97]$ ); e Participação Social (Inicial 66,25 [ $[ \pm 10,70]$ e Final 72,50 $[ \pm 19,81])$ apresentam pontuação positiva. Mesmo com as variações indicadas, tanto positivas como negativas, os resultados de todas as facetas não registraram índices estatisticamente significantes para a pesquisa. 
Figura 13 apresenta avaliação individual dos voluntários do grupo G1 pelo instrumento WHOQOL-OLD.
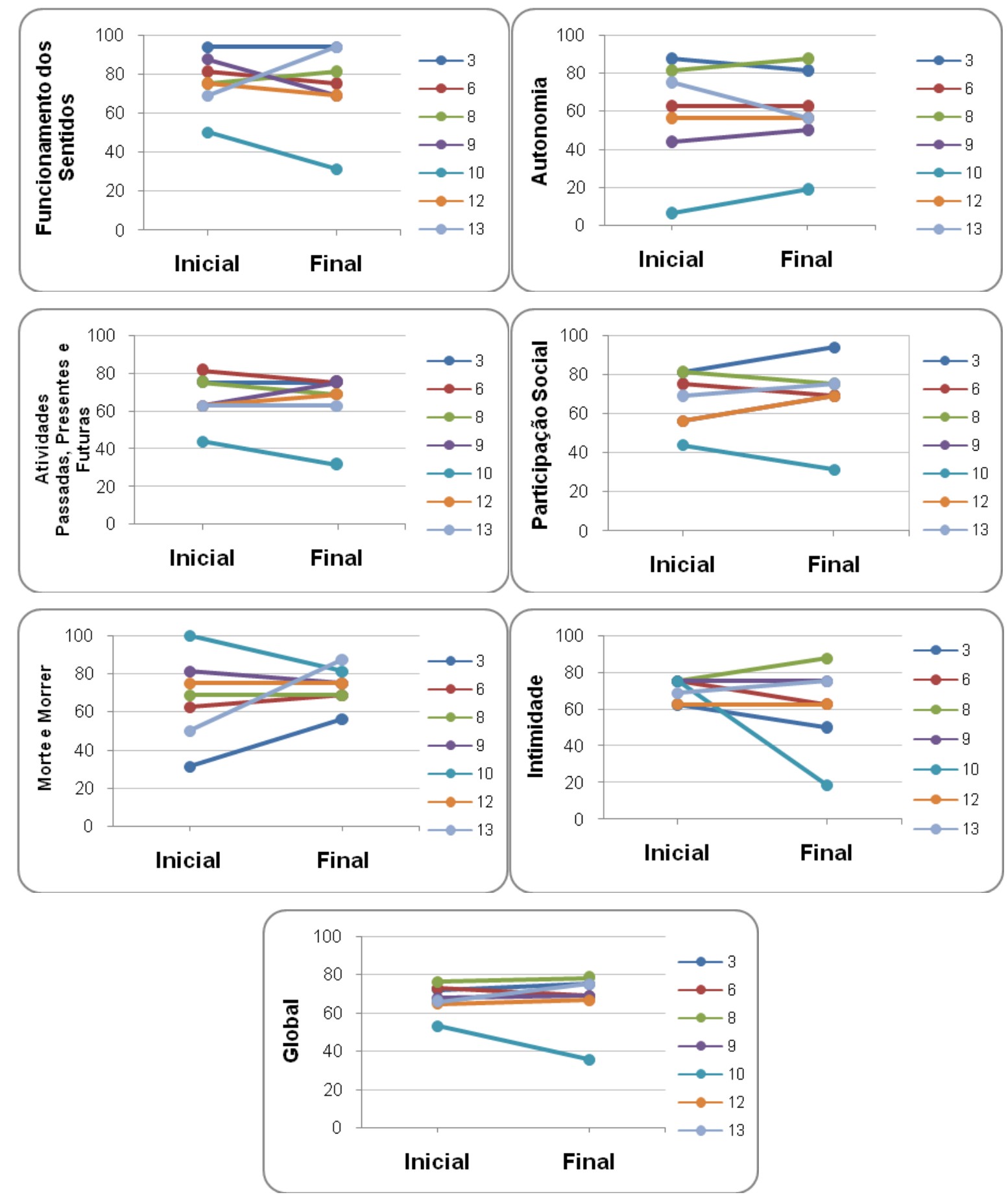

Figura 13. Valores individuais das facetas Funcionamento dos Sentidos, Autonomia, Atividades Passadas, Presentes e Futuras, Participação Social, Morte e Morrer, Intimidade e Global avaliadas pelo WHOQOL-OLD, obtidos a partir das respostas fornecidas pelos voluntários da $3^{\underline{a}}$ idade, integrantes do Grupo 1. 
A Figura 13 ilustra graficamente o desempenho dos indivíduos do G1, onde é indicado, na Faceta Funcionamento dos Sentidos, que apenas o voluntário 13 apresentou evolução positiva acentuada, de 69 para 94 (em uma escala de 0 a 100 pontos), e, de maneira mais discreta, o voluntário 8, de 75 para 81. Já os demais participantes da pesquisa, voluntários 6 , 9, 10, 12 e 3, apresentaram evolução negativa, com destaque para o voluntário 10, com pontuação inicial de 50, mas que decaiu para 31 na etapa seguinte, final. Na segunda Faceta avaliada, Autonomia, com exceção do voluntário 8, os demais apresentaram variação inversa àquela obtida na Faceta anterior, Funcionamento dos Sentidos. Chama atenção a variação do voluntário 10, de 6 para 19. Na Faceta Atividades Passadas, Presentes e Futuras, as variações tanto positivas como negativas mantiveram a tendência dos indivíduos do G1, indicando boa avaliação pessoal, com pontuação acima de 60, assim como o voluntário 10 ser o único indivíduo a fugir dessa característica. Na Faceta Participação Social, quatro voluntários $(3,13$, 12 e 9) avaliaram melhor sua percepção na segunda etapa da pesquisa e os voluntários 8, 6 e 10 indicaram declínio. A Faceta Morte e Morrer foi avaliada com resultado positivo pela maioria dos indivíduos do G1, as exceções foram os voluntários 10 e 9. A faceta Intimidade apresenta dois voluntários com resultados marcadamente opostos entre si, o voluntário 8 com evidente variação positiva e o voluntário 10 com resultado acentuadamente negativo. Os demais voluntários apresentaram variações tanto positivas como negativas muito próximas. Por fim, em relação à Figura 13, com dados individuais dos voluntários do G1, a Faceta Global apresentou variações negativas para as avaliações dos voluntários 10 e 6 , entre a fase inicial e final, enquanto para as dos demais, positivas. 
A Figura 14 apresenta avaliação individual dos voluntários do grupo G2 pelo instrumento WHOQOL-OLD.
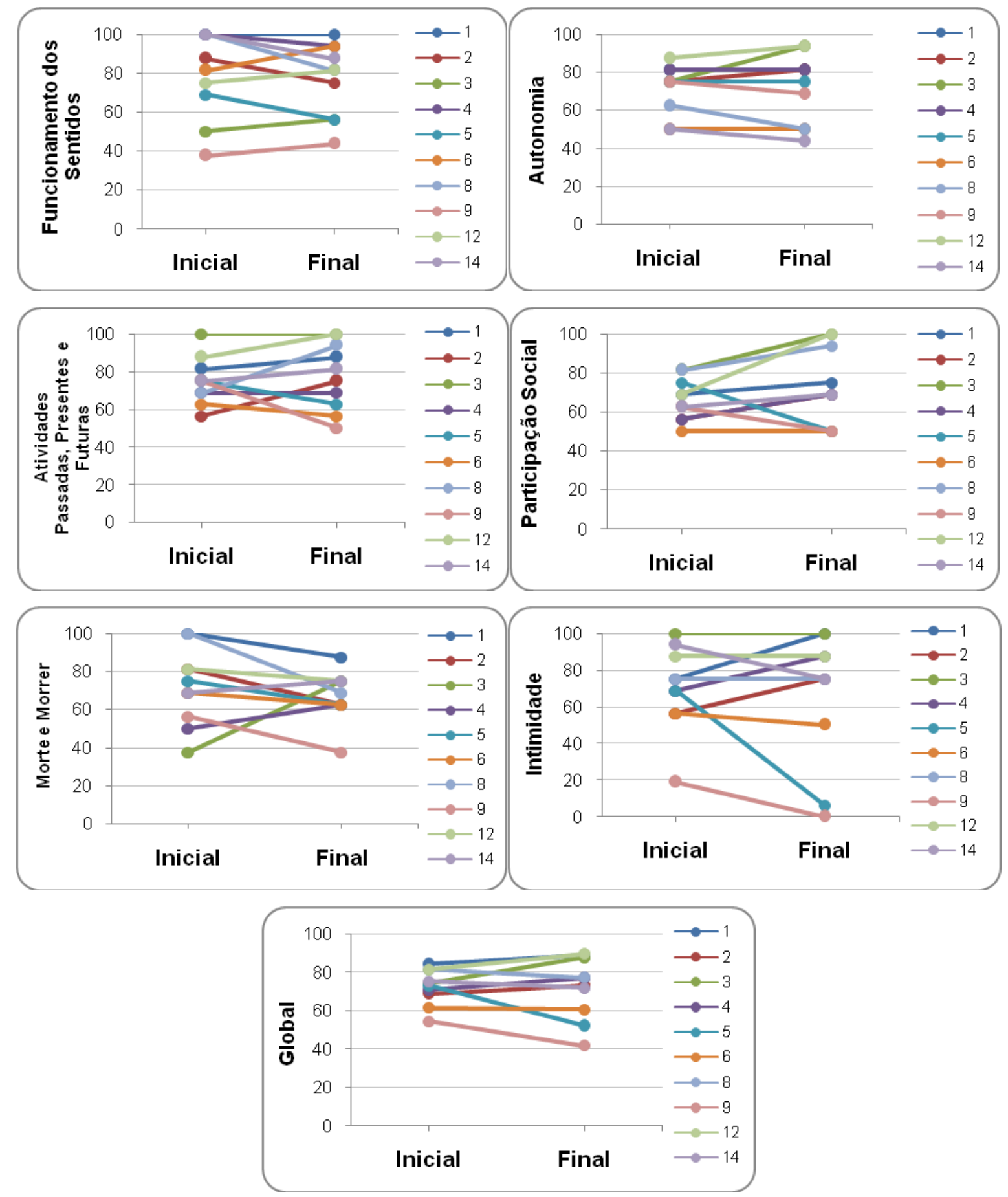

Figura 14. Valores individuais das facetas Funcionamento dos Sentidos, Autonomia, Atividades Passadas, Presentes e Futuras, Participação Social, Morte e Morrer, Intimidade e Global avaliadas pelo WHOQOL-OLD, obtidos a partir das respostas fornecidas pelos voluntários da 3a idade, integrantes do Grupo 2. 
A Figura 14 mostra a Faceta Funcionamento dos Sentidos sendo avaliada individualmente pelos voluntários do G2 de forma equilibrada. Nela chama atenção o resultado do voluntário 1 que, tanto na primeira (inicial) como na segunda fase (final), apresentou a mesma pontuação (100, máximo possível). Já os voluntários 2, 4, 5, 8 e 14 indicaram declínio na sua avaliação; enquanto que os voluntários 3, 6, 9 e 12 apresentaram variação positiva. Na Faceta Autonomia os resultados sem alteração entre a fase inicial e final é que chamam atenção, presentes na avaliação dos voluntários 1, 4, 5 e 6. Já as variações negativas ficaram por conta dos voluntários 8, 9 e 14 e as positivas foram confirmadas pelos voluntários 2, 3 e 12. A Faceta Atividades Passadas, Presentes e Futuras apresentou como característica a pontuação acima de 50 para todos os voluntários avaliados, tanto na primeira fase (inicial) como na segunda (final), independente da variação positiva ou negativa: os voluntários $(1,2,8,12,14)$ se autoavaliaram de forma positiva; dois outros, 3 e 4, mantiveram os mesmos valores nas duas fases, enquanto os voluntários 5, 6 e 9 apresentaram valores abaixo daqueles indicados na primeira fase. A Faceta Participação Social, além de apresentar pontuação individual para todos os participantes acima de 50 em sua avaliação, indica também que os voluntários 1, 2, 3, 4, 8, 12 e 14 tiveram variação positiva; dois outros, 5 e 9, negativa; enquanto que o voluntário 6 apresentou a mesma pontuação entre as duas fases avaliadas. Na Faceta Morte e Morrer, enquanto os demais voluntários variaram seus valores dentro de índices muito próximos, os voluntários 3 e 8 se diferiram por apresentarem valores opostos entre as fases Inicial e Final, 37 e 75, e 100 e 68, respectivamente. A Faceta Intimidade apresentou a maior amplitude de variabilidade entre todas as facetas avaliadas pelos indivíduos do G2, com valores alcançando os extremos possíveis de pontuação, 0 e 100 . O voluntário 3, além de permanecer com os mesmos valores nas duas fases, acentuou sua total compatibilidade com aspectos dessa faceta, auto avaliando-se com o valor máximo, 100. Em movimento oposto, o voluntário 9, que já tinha valor inicial baixo, 19, finalizou sua autoavaliação sem creditar nenhum valor a esse item, ou seja, o resultado final foi 0. Outro dado que chamou atenção foi o voluntário 5, que decresceu de 68 para 6. Já os voluntários 8 e 12 mantiveram o mesmo nível de avaliação sem alterar seus valores.

Na Faceta Global observa-se que a fase inicial tem amplitude de pontuação entre 55 a 84, e na fase final essa amplitude se expande tanto para baixo como para cima, ou seja, seus valores vão de 41 a 90. Os voluntários 5, 6, 8, 9 e 14 colaboraram para que os valores dessa faceta fossem menores que na fase anterior e os voluntários 1, 2, 3, 4 e 12 elevam sua 
pontuação, acentuando evidente equilíbrio na variação dos escores entre as duas fases, com maior concentração entre os escores de 60 a 80 .

Tabela 12. Valores obtidos com o Cambridge Cognitive Test - CAMCOG, e o Mini Exame do Estado Mental - MEEM, a partir das respostas fornecidas pelos voluntários da $3^{\underline{a}}$ idade, Grupo 1.

\begin{tabular}{ccccc}
\hline Voluntário & $\begin{array}{c}\text { Inicial } \\
\text { CAMCOG }\end{array}$ & $\begin{array}{c}\text { Final } \\
\text { CAMCOG }\end{array}$ & $\begin{array}{c}\text { Inicial } \\
\text { MEEM }\end{array}$ & $\begin{array}{c}\text { Final } \\
\text { MEEM }\end{array}$ \\
\hline 6 & 102 & 102 & 28 & 30 \\
8 & 98 & 101 & 28 & 30 \\
12 & 97 & 91 & 30 & 28 \\
13 & 103 & 106 & 29 & 30 \\
\hline
\end{tabular}

A Tabela 12, relacionada aos valores creditados à avaliação efetuada pelo CAMCOG, com exceção do voluntário 6, apresentou um quadro estável entre as aferições de funções cognitivas pré e pós-treinamento. Também se nota que, apesar da pontuação das respostas não chegar ao valor considerado máximo, de 107 pontos - com exceção da pontuação obtida na fase final pelo voluntário 12, que foi de 91 pontos, os demais resultados ficaram próximos desse limite, com o voluntário 8 apresentando os valores de 98 para 101, e no caso do voluntário 13, de 103 para 106. Como os valores obtidos com o CAMCOG não são interpretados globalmente, pois dizem respeito à pontuação conseguida pelas funções cognitivas avaliadas isoladamente, evidencia-se assim que, no caso do voluntário 12, o valor negativo na segunda fase de aplicação do teste foi devido à avaliação negativa da função "memória", de 20 para 14, conforme descrição dos valores das subáreas do CAMCOG, Apêndice X, página 163. Já os voluntários que aumentaram sua pontuação, isso foi devido à melhor avaliação da função "memória", de 21 para 24 (voluntário 8), "atenção e pensamento abstrato", de 6 para 7, e de 6 para 8, respectivamente (voluntário 13).

Os valores obtidos pela avaliação do MEEM indicam que a variação entre as fases inicial e final foi mínima e a pontuação alcançada mostrou evolução positiva para a maioria dos entrevistados, com variações de 28 a 30 pontos. A exceção, também evidenciada pelo CAMCOG, ficou por conta da voluntária 12, que apresentou pontuação em declínio entre as fases Inicial e Final, ou seja, na fase Inicial o valor foi de 30 e na Final, 28. 
Tabela 13. Valores obtidos com o Cambridge Cognitive Test - CAMCOG e o Mini Exame do Estado Mental - MEEM, a partir das respostas fornecidas pelos voluntários da $3^{\underline{a}}$ idade, Grupo 2.

\begin{tabular}{ccccc}
\hline Voluntário & $\begin{array}{c}\text { Inicial } \\
\text { CAMCOG }\end{array}$ & $\begin{array}{c}\text { Final } \\
\text { CAMCOG }\end{array}$ & $\begin{array}{c}\text { Inicial } \\
\text { MEEM }\end{array}$ & $\begin{array}{c}\text { Final } \\
\text { MEEM }\end{array}$ \\
\hline 2 & 98 & 99 & 28 & 30 \\
3 & 103 & 100 & 30 & 29 \\
5 & 94 & 101 & 29 & 30 \\
6 & 96 & 93 & 27 & 28 \\
8 & 97 & 95 & 27 & 29 \\
9 & 103 & 105 & 30 & 30 \\
12 & 101 & 101 & 28 & 28 \\
14 & 101 & 102 & 27 & 29 \\
\hline
\end{tabular}

A Tabela 13 expõe os valores cognitivos relativos aos instrumentos CAMCOG e MEEM para os voluntários do G2. Os números evidenciam pouca alteração entre as fases Inicial e Final, que no caso do CAMCOG fica entre 93 e 105 pontos; e para o MEEM, entre 27 e 30 pontos. É indicado tanto pelos resultados do CAMCOG como pelos do MEEM, que um maior número de voluntários apresentou evolução positiva de seus valores entre as fases Inicial e Final, como são os casos dos voluntários 2, 5, 9, 14. Incide sobre essa melhor pontuação a evolução sobre as funções (Apêndice X, página 163) "memória", de 20 para 24 (voluntários 5), de 24 para 26 (voluntário 9); “linguagem”, de 27 para 28 (voluntário 2), de 27 para 29 (voluntário 14). Alguns resultados não seguem essa tendência, como são os casos dos voluntários 3, 6 e 8, com oscilação decrescente dos valores de 103 para 100, 96 para 93, e 97 para 95, respectivamente. O declínio na pontuação aconteceu, conforme descrição das subáreas no apêndice desta pesquisa, sobre as seguintes funções cognitivas: "memória", de 27 para 24 (voluntário 3), de 22 para 19 (voluntário 6) e de 23 para 22 (voluntário 8); e "percepção", de 10 para 7 (voluntário 8). Já os resultados do MEEM, para esses mesmos voluntários, indicaram que apenas o voluntário 3 segue a tendência de queda na pontuação, de 30 para 29, e que a pontuação dos outros dois voluntários indicou o contrário, ou seja, evolução positiva de 27 para 28 (voluntário 6), e de 27 para 29 (voluntário 8). Ainda um terceiro caso, o voluntário 12, apresentou valores inalterados nas duas fases, 101 pontos aferidos no CAMCOG, e 28 no MEEM. 
Tabela 14. Índice no início da pesquisa da Massa Corporal - IMC - dos voluntários da $3^{\mathrm{a}}$ idade, integrantes do Grupo 1.

\begin{tabular}{cccc}
\hline Voluntário & Altura $(\mathrm{cm})$ & Peso $(\mathrm{Kg})$ & $\mathrm{IMC}\left(\mathrm{Kg} / \mathrm{m}^{2}\right)$ \\
\hline 4 & 162,5 & 66,35 & 25,1 \\
6 & 148,5 & 72,00 & 32,6 \\
8 & 151,2 & 57,75 & 25,3 \\
9 & 157,5 & 75,00 & 30,2 \\
10 & 155,0 & 60,00 & 25,0 \\
12 & 148,0 & 57,40 & 26,2 \\
13 & 165,5 & 78,00 & 28,5 \\
\hline
\end{tabular}

Tabela 15. Índice no início da pesquisa da Massa Corporal - IMC - dos voluntários da $3^{\underline{a}}$ idade, integrantes do Grupo 2.

\begin{tabular}{cccc}
\hline Voluntário & Altura $(\mathrm{cm})$ & Peso $(\mathrm{Kg})$ & $\mathrm{IMC}\left(\mathrm{Kg} / \mathrm{m}^{2}\right)$ \\
\hline 2 & 164,4 & 63,60 & 23,5 \\
3 & 163,0 & 70,00 & 26,3 \\
5 & 154,3 & 64,65 & 27,2 \\
6 & 153,0 & 71,00 & 30,3 \\
8 & 150,2 & 69,40 & 30,8 \\
9 & 165,3 & 77,70 & 28,4 \\
12 & 157,0 & 84,00 & 34,1 \\
14 & 152,4 & 75,35 & 32,4 \\
\hline
\end{tabular}

Os dados das tabelas 14 e 15 foram calculados considerando como referência os valores estipulados no Quadro 2. Assim, na Tabela 14, com índices dos integrantes do G1, evidencia-se que não há no grupo nenhum indivíduo com classificação "normal”, ou seja, com IMC entre 18,5 e 24,9. Os voluntários 4, 8, 10, 12 e 13 apresentaram índices que os colocaram na classificação "pré-obeso" (IMC entre 25,0 e 29,9), com risco de doença “Aumentado"; enquanto que os voluntários 6 e 9 foram incluídos na classificação "Obeso grau I" (IMC entre 30,0 e 34,9), com risco de doença "moderado". 
Já a Tabela 15, com índices dos voluntários do G2, apresenta um caso (voluntário 2) que se inclui na classificação "normal", sem risco de doença, e três voluntários $(3,5$ e 9) na classificação "Pré-obeso", com risco de doença “Aumentado". Porém a maioria (voluntários 6, 8, 12 e 14) se incluiu na classificação "obeso grau I", com risco de doença "Moderado".

Tabela 16. Índices no início da pesquisa da Circunferência Abdominal e RCQ dos voluntários da $3^{\underline{a}}$ idade, integrantes do Grupo 1.

\begin{tabular}{cccc}
\hline Voluntário & Cintura $(\mathrm{cm})$ & Quadril $(\mathrm{cm})$ & RCQ \\
\hline 3 & 88,0 & 103,4 & 0,85 \\
6 & 97,0 & 115,0 & 0,84 \\
8 & 74,0 & 102,0 & 0,73 \\
9 & 97,0 & 105,5 & 0,92 \\
10 & 76,5 & 106,0 & 0,72 \\
12 & 96,2 & 98,7 & 0,97 \\
13 & 99,0 & 111,0 & 0,89 \\
\hline
\end{tabular}

Tabela 17. Índices no início da pesquisa da Circunferência Abdominal e RCQ dos voluntários da $3^{\text {a }}$ idade, integrantes do Grupo 2.

\begin{tabular}{cccc}
\hline Voluntário & Cintura $(\mathrm{cm})$ & Quadril $(\mathrm{cm})$ & RCQ \\
\hline 2 & 84,4 & 103,8 & 0,81 \\
3 & 88,5 & 97,0 & 0,91 \\
5 & 83,0 & 101,5 & 0,82 \\
6 & 93,0 & 106,0 & 0,88 \\
8 & 95,0 & 112,0 & 0,85 \\
9 & 95,5 & 106,0 & 0,90 \\
12 & 97,0 & 120,0 & 0,81 \\
14 & 95,0 & 107,0 & 0,89 \\
\hline
\end{tabular}

As Tabelas 16 e 17 apresentam resultados dos voluntários dos grupos 1 e 2, respectivamente. No G1, Tabela 16, os voluntários $8(\mathrm{RCQ}=0,73 \mathrm{~cm})$ e $10(\mathrm{RCQ}=0,72 \mathrm{~cm})$, pertencentes ao sexo feminino, evidenciam medidas com classificação fora da faixa de risco 
de doença. Na faixa de classificação com risco de doença "aumentado", encontram-se os voluntários (mulheres) $3(\mathrm{RCQ}=91 \mathrm{~cm})$ e $6(\mathrm{RCQ}=0,84 \mathrm{~cm})$, enquanto que os demais participantes do grupo, voluntários 9, 12 e 13, foram classificados com risco de doença "alto" (RCQ maior que $0,85 \mathrm{~cm}$ ).

No G2, Tabela 17, não há nenhum caso fora da faixa de risco de doença. Nesse grupo, o voluntário 3, do sexo masculino, apresentou medidas de classificação com risco de doença “aumentado”, conforme Quadro 3, ou seja, seu RCQ foi igual a $91 \mathrm{~cm}$. Os demais voluntários, todos mulheres, foram classificados em duas faixas de risco de doença: "aumentado" (voluntários 2, 5 e 12, RCQs $=0,81 \mathrm{~cm}, 0,82 \mathrm{~cm}, 0,81 \mathrm{~cm}$, respectivamente) e "alto" (voluntários 6,8,9 e 14, RCQs $=0,88 \mathrm{~cm}, 0,85 \mathrm{~cm}, 0.90 \mathrm{~cm}$ e $0,89 \mathrm{~cm}$, respectivamente).

Tabela 18. Pressão arterial no início da pesquisa dos voluntários da $3^{3}$ idade, integrantes do Grupo 1

\begin{tabular}{ccc}
\hline Voluntário & $\begin{array}{c}\text { Sistólica } \\
(\mathrm{mmHg})\end{array}$ & $\begin{array}{c}\text { Diastólica } \\
(\mathrm{mmHg})\end{array}$ \\
\hline 3 & 144,3 & 71,0 \\
6 & 153,3 & 75,3 \\
8 & 119,0 & 80,0 \\
9 & 132,7 & 85,0 \\
10 & 155,7 & 75,3 \\
12 & 156,7 & 69,7 \\
13 & 109,7 & 68,7 \\
\hline
\end{tabular}

A Tabela 18 evidencia que no G1 a maioria dos voluntários (3, 6, 8, 1012 e 13) apresentou resultados da diastólica abaixo de $85 \mathrm{mmHg}$, e apenas o voluntário 9 com 85 mmHg. A sistólica teve maior variabilidade, sendo dois voluntários (8 e 13) com valores abaixo de $130 \mathrm{mmHg}$; um voluntário (9), medindo entre 130 e 139, e os demais voluntários (3, 6, 10 e 12), medindo entre 140 e 159. Chamam atenção as medidas dos voluntários 8 e 13, com a pressão sistólica medindo 119,0 e 109,7, e a diastólica, 80 e 68,7, respectivamente. 
Tabela 19. Pressão arterial no início da pesquisa $(\mathrm{mmHg})$ dos voluntários da $3^{\underline{a}}$ idade, integrantes do Grupo 2.

\begin{tabular}{ccc}
\hline Voluntário & $\begin{array}{c}\text { Sistólica } \\
(\mathrm{mmHg})\end{array}$ & $\begin{array}{c}\text { Diastólica } \\
(\mathrm{mmHg})\end{array}$ \\
\hline 2 & 144,3 & 84,3 \\
3 & 142,3 & 89,7 \\
5 & 109,0 & 67,3 \\
6 & 128,3 & 72,0 \\
8 & 163,7 & 78,3 \\
9 & 138,0 & 72,0 \\
12 & 131,3 & 75,3 \\
14 & 143,3 & 70,3 \\
\hline
\end{tabular}

A Tabela 19, com dados sobre a pressão arterial dos integrantes do G2, assim como aconteceu no G1, Tabela 19, mostra que a maioria dos voluntários $(2,5,6,8,9,12$ e 14) apresentou resultados indicando que a pressão diastólica está abaixo de $85 \mathrm{mmHg}$ e apenas o voluntário 3, único do sexo masculino do grupo, obteve medida acima desse valor, 89,7 mmHg. As medidas para a pressão sistólica evidenciaram maior variação entre as referências de classificação, ou seja, os voluntários 5 e 6 apresentaram resultados abaixo de $130 \mathrm{mmHg}$; os voluntários 9 e 12 tiveram suas medidas entre 130 e 139 mmHg, e os voluntários 2, 3 e 14, entre 140 e 159 mmHg. Já o voluntário 8 apresentou medidas para a sistólica de 163,7 mmHg.

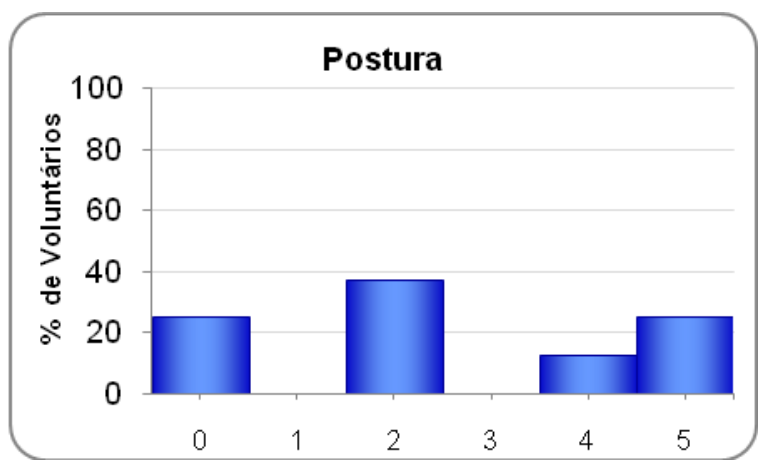

Figura 15. Autoavaliação final do desempenho Postural dos voluntários da $3^{\underline{a}}$ idade Grupo 2.

A Figura 15 informa os valores percentuais referentes à primeira questão abordada pelo questionário baseado na Escala Likert e aplicado aos voluntários do G2, aquela que inquire a respeito da postura. O número de voluntários observados foi de 8 , o mesmo " $\mathrm{n}$ " para todos os outros itens desse instrumento. Os números na horizontal dos gráficos correspondem aos 
níveis das perguntadas formuladas: Não melhorou (0), Melhorou pouco (1), Teve razoável melhora (2), Teve boa melhora (3), Teve ótima melhora (4) e Teve excelente melhora (5), e, na vertical, a quantidade de voluntários que optaram por determinada resposta.

No primeiro aspecto avaliado da postura, três voluntários $(37,5 \%)$ indicaram que houve razoável melhora, enquanto dois $(25 \%)$ responderam não ter tido nenhuma alteração postural. Igual número de participantes, dois (25\%), optou por afirmar que obtive excelente melhora, e apenas um $(12,5 \%)$ avaliou como ótima a melhora.

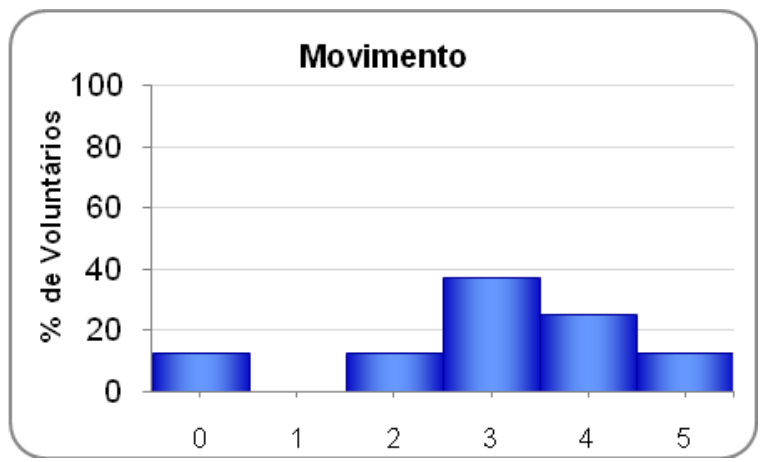

Figura 16. Autoavaliação final do desempenho de Movimento corporal dos voluntários da $3^{\mathfrak{a}}$ idade Grupo 2.

A Figura 16 indica as respostas relativas à percepção sobre o desempenho do movimento logo após o treinamento cênico. As respostas com avaliação entre boa, excelente e ótima foram indicadas por seis voluntários (75\%). Dos 25\% restantes, um voluntário respondeu não ter havido melhora alguma, e outro disse ter tido razoável melhora. No total, conforme evidencia o Gráfico 2, sete voluntários $(87,5 \%)$ avaliaram que houve melhora na realização de seus movimentos corporais. 


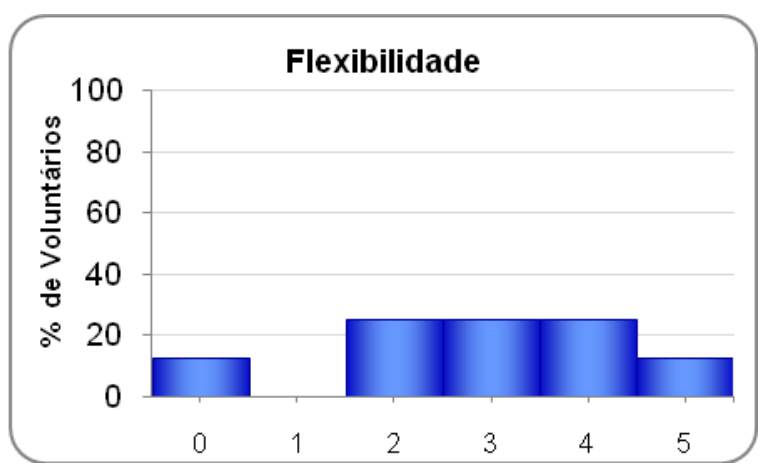

Figura 17. Autoavaliação final do desempenho de Flexibilidade dos voluntários da $3^{\mathrm{a}}$ idade - Grupo 2

A Figura 17 apresenta o resultado da autoavaliação referente ao desempenho da flexibilidade dos integrantes do G2. Ele evidencia que apenas um voluntário (12,5\%) não creditou melhoras ao seu desempenho, optando pela resposta "Não melhorou". Já a maioria $(87,5 \%)$ optou por respostas diferentes e que acentuaram mudanças no seu desempenho sobre a flexibilidade, ou seja, dois voluntários (25\%) indicaram que a melhora fora razoável, e outros dois (25\%), que fora boa; assim como mais dois (25\%) avaliaram como ótima; enquanto que um voluntário (12,5\%) avaliou como excelente.

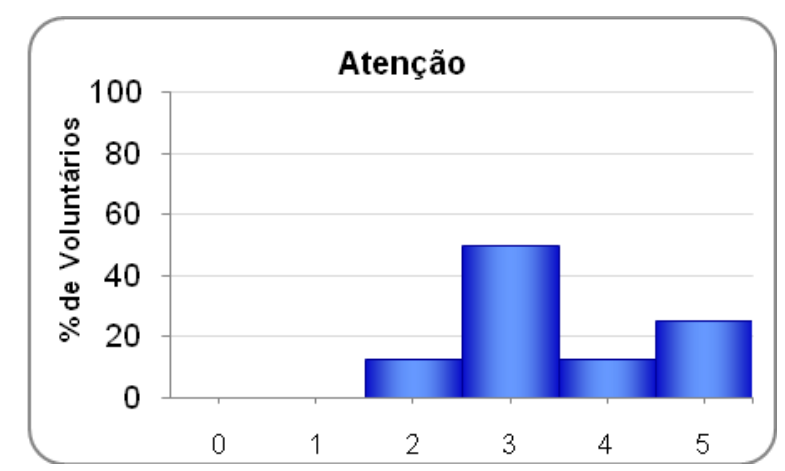

Figura 18. Autoavaliação final do desempenho de Atenção dos voluntários da $3^{\mathrm{a}}$ idade -Grupo 2

A Figura 18 evidencia que todos os voluntários do G2 (100\%) avaliaram seu desempenho em relação à atenção de forma positiva. Destaca-se a avaliação feita por quatro voluntários (50\%), indicando boa melhora no seu desempenho sobre a atenção; dois voluntários (25\%) indicaram excelente melhora; um voluntário $(12,5 \%)$ ótima, e outro voluntário $(12,5 \%)$, como razoável. 


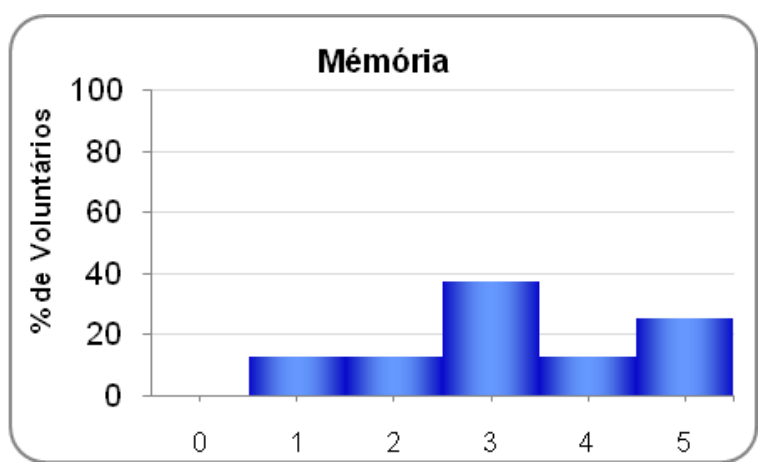

Figura 19. Autoavaliação final do desempenho de Memória dos voluntários da $3^{\mathrm{a}}$ idade - Grupo 2

A Figura 19, que apresenta as respostas dadas pelos voluntários quanto ao seu desempenho da memória, após o treinamento cênico oferecido, evidencia que, na avaliação de três voluntários $(37,5 \%)$, ocorreu boa melhora, e, para outros dois $(25 \%)$, a melhora foi excelente. Os três voluntários restantes $(37,5 \%)$ indicaram, cada um deles, uma resposta diferente, ou seja, um indicou que houve pouca melhora, outro que foi razoável e o último respondeu que houve ótima melhora.

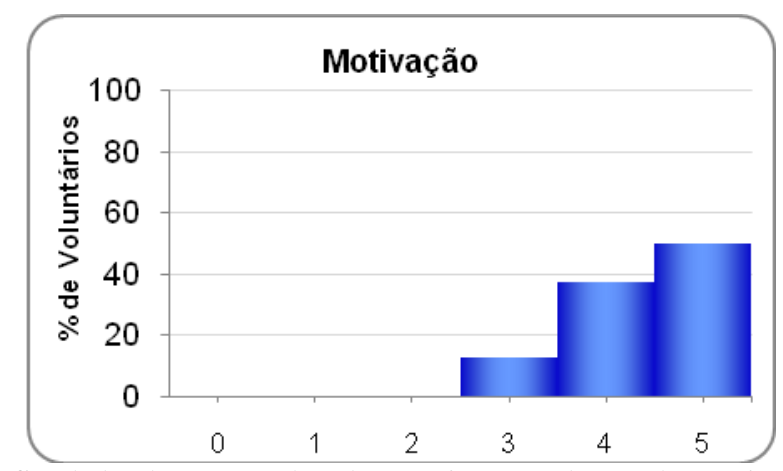

Figura 20. Autoavaliação final do desempenho de Motivação dos voluntários da $3^{\text {a }}$ idade - Grupo 2

A Figura 20 evidencia que os voluntários do G2 escolheram os critérios mais positivos do questionário aplicado, ou seja, avaliaram seu desempenho motivacional entre boa e excelente melhora. Destaca-se a resposta dada à excelente melhora, com quatro voluntários (50\%) optando por ela. Já a percepção de ótima melhora é creditada por três voluntários $(37,5 \%)$ e, por fim, $12,5 \%$ responderam ter sido boa a sua melhora sobre o aspecto trabalhado. 


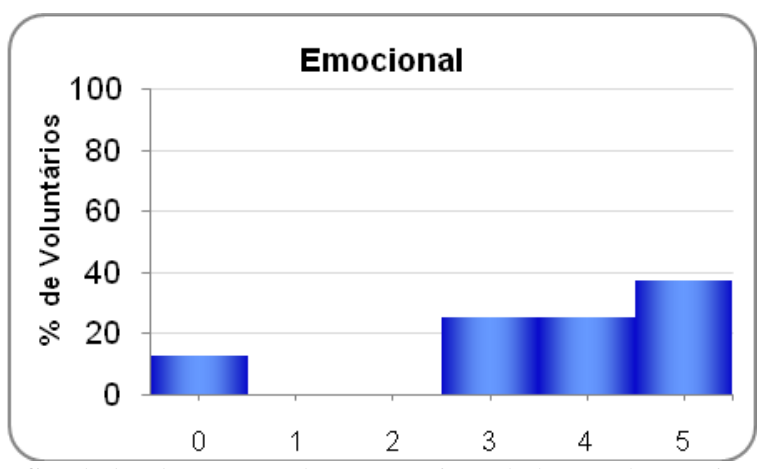

Figura 21. Autoavaliação final do desempenho Emocional dos voluntários da $3^{\underline{a}}$ idade - Grupo 2

A Figura 21 avalia o aspecto emocional dos voluntários logo após o treinamento proporcionado. Nele se evidencia que três voluntários $(37,5 \%)$ indicaram na sua avaliação terem tido excelente melhora. A percepção de ótima melhora também foi contemplada na avaliação de dois voluntários (25\%), assim como boa melhora por outros dois voluntários (25\%). Um voluntário (12\%) avaliou que nenhuma melhora foi conseguida durante o treinamento oferecido.

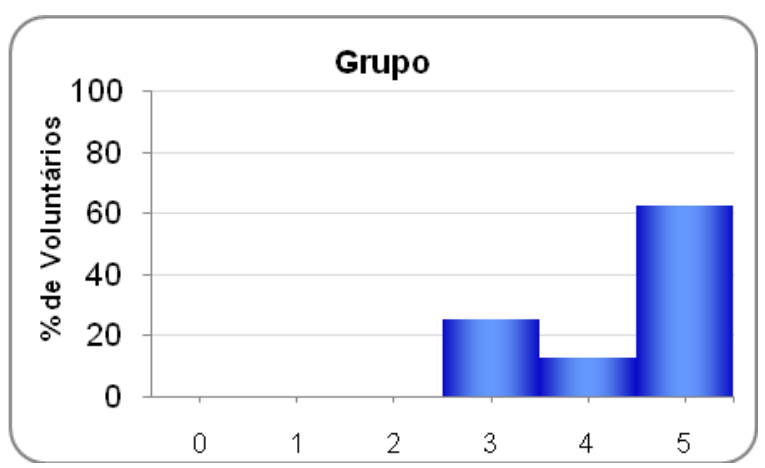

Figura 22. Autoavaliação final do desempenho do Relacionamento dentro do Grupo de voluntários da $3^{\mathrm{a}}$ idade - Grupo 2

A Figura 22 apresenta o grau de relacionamento conquistado e percebido pelos integrantes do G2. Os dados evidenciam que $100 \%$ dos voluntários indicaram terem tido mudanças positivas no relacionamento dentro do grupo, sendo que 5 voluntários (62\%) responderam terem tido excelente melhora, enquanto dois outros voluntários (25\%) optaram por avaliar boa melhora. Um voluntário (12\%) respondeu ter tido ótima melhora no relacionamento dentro grupo. 


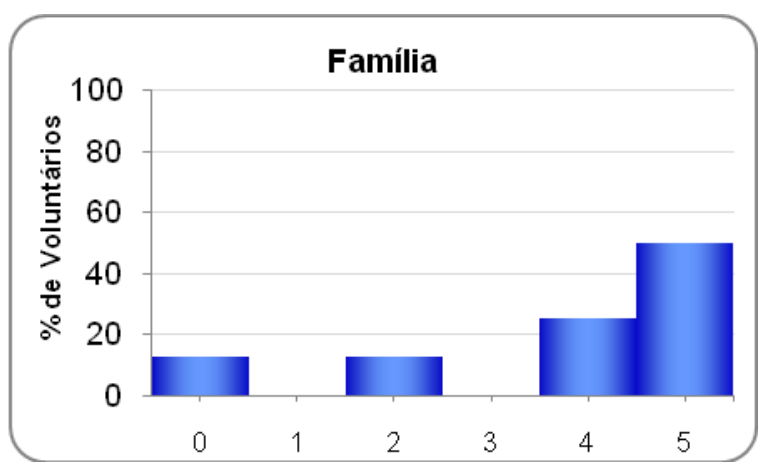

Figura 23. Autoavaliação final de desempenho do Relacionamento dos voluntários da $3^{\mathrm{a}}$ idade com a Família - Grupo 2

A Figura 23 evidencia que 87,5\% dos voluntários, ou seja, sete integrantes do G2, indicaram melhoras de desempenho de relacionamento com a família após o treinamento cênico desenvolvido, e apenas um (12,5\%) acentuou o contrário. A maioria dos voluntários, quatro $(50 \%)$, respondeu ter tido ótima melhora no seu relacionamento familiar, enquanto dois voluntários (25\%) indicaram terem tido ótima melhora. Já a resposta de melhora razoável foi indicada por um voluntário (12,5\%) e outro voluntário (12,5\%) avaliou seu desempenho sobre esse aspecto sem melhora alguma.

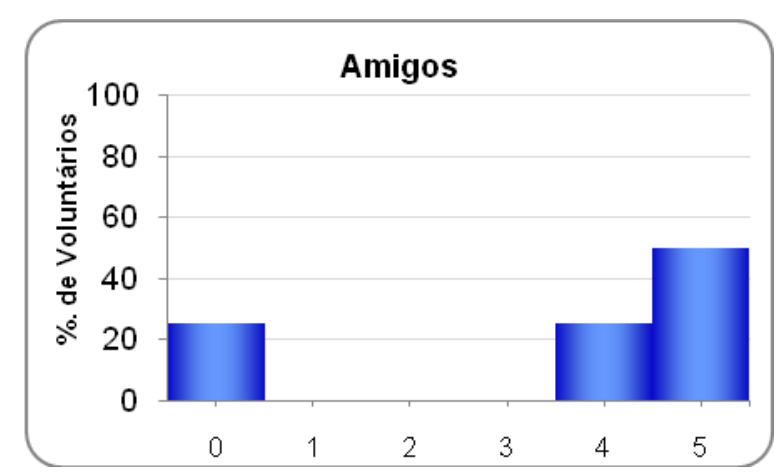

Figura 24. Autoavaliação final do desempenho do Relacionamento dos voluntários da $3^{\underline{a}}$ idade com Amigos - Grupo 2

A Figura 24 apresenta informações do grau de percepção sobre a melhora ou não de relacionamento dos voluntários com seus amigos externos ao grupo. No gráfico é evidenciado que 6 voluntários $(75 \%)$ destinaram suas respostas a mudanças positivas no relacionamento com amigos, sendo que quatro voluntários $(50 \%)$ avaliaram terem tido excelente melhora, enquanto dois outros voluntários (25\%), ótima melhora. O Gráfico 10 também mostra que dois voluntários (25\%) responderam não ter havido qualquer melhora no seu relacionamento com amigos. 


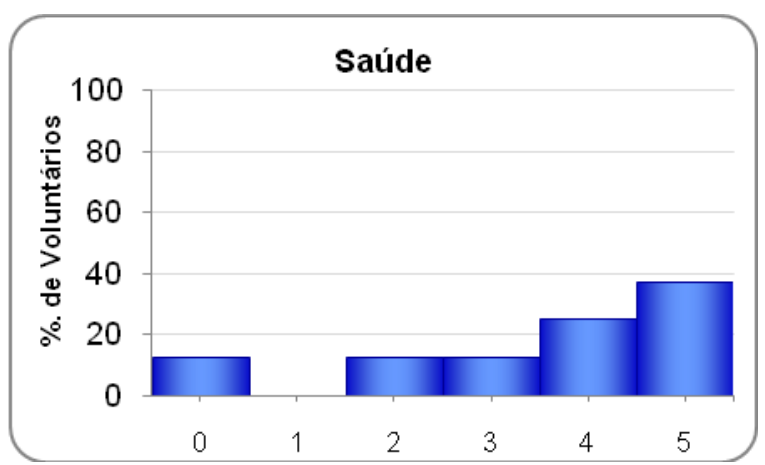

Figura 25. Autoavaliação final do desempenho da Saúde dos voluntários da $3^{\underline{a}}$ idade - Grupo 2.

A Figura 25 evidencia a avaliação dadas pelos voluntários do G2 quanto ao desempenho da saúde após o treinamento cênico oferecido. Sua apresentação acentua que 87,5\% das respostas dadas pelos voluntários incidiram sobre a percepção de melhoras em sua saúde e apenas 12,5\% mostra o contrário. A resposta de excelente melhora é indicada por 3 voluntários $(37,5 \%)$, enquanto a resposta de ótima melhora é confirmada por dois outros voluntários (25\%). A avaliação de boa melhora foi mencionada por um voluntário $(12,5 \%)$, assim como razoável (um voluntário, 12,5\%) e sem nenhuma melhora (um voluntário, $12,5 \%)$.

A pesquisa qualitativa desenvolvida nesse projeto se concentrou no G2, e um dado muito significativo sobre a importância do trabalho cênico realizado com essa população em questão foi que a observação, o registro em foto e vídeo, os depoimentos sobre seus resultados evidenciaram ganhos, em ambos os sexos, quanto à aceitação e envolvimento nas propostas, conforme se observa nas declarações a seguir:

"Quando completei 60 anos... Hoje me sinto mais solta e consigo memorizar pequenos textos, coisa que eu achava ser impossivel para mim. Também estou na expectativa de melhorar a voz. A experiência teatral é fascinante. Mágica e enriquecedora” (EF).

"Engraçado, quando eu cheguei na Estação Ciência, para conhecer o grupo Só com Experiência, eu não tinha a noção do que era fazer teatro. Foi assim quase por acaso. Mas aí eu fui gostando, porque, a cada momento que eu me expunha, eu sentia vergonha e logo após a satisfação de ter superado mais um desafio" (CAR).

Também possibilitou alcançar os objetivos traçados, com notória aquisição de novo vocabulário, de laços afetivos, de atividades sociais e culturais extra-espaço de trabalho, de força muscular e reações posturais, novas atividades intelectuais, reorganização da marcha e cuidados pessoais, como de higiene e limpeza. 
“... o interessante é que esse apreendido nos levou a identificar, estudar, observa um esqueleto, isto é, partes do corpo humano" (AS).

“... estarei próxima das pessoas que formam o grupo, ouvindo-as, trocando e compartilhando experiências, para cultivar o respeito mútuo, o desenvolvimento social e emocional" (IL).

No momento inicial ao do desenvolvimento da pesquisa com o G2, buscou-se saber qual era o grau de interesse ou mesmo o porquê dessas pessoas com idade acima de 60 anos de idade tomarem a decisão de fazer uma atividade como a proposta, de pesquisa cênica. Sem pretender exaurir as repostas para tal pergunta, mas indicar justamente o contrário: fomentar suas possibilidades.

O formulário de pesquisa para essa atividade foi denominado de "Depoimento 1", Apêndice IV, página 153.

A seguir, são apresentados alguns recortes de depoimentos dos participantes, explicitando sua expectativa sobre a atividade, conforme transcrição, Apêndice XVII, página 175:

“... sempre brinquei de fazer de conta porque tudo o que fiz foi para agradar as pessoas, negando o meu próprio eu. Eu sempre ocultei os meus sonhos para mostrar ao mundo as qualidades que a sociedade aprova. Só entre 63 e 64 anos, por sorte, eu soube que haveria aulas de teatro para pessoas da minha faixa etária na Estação Ciência; e assim entrei para o desconhecido, arriscando em desafio e ousadia $e$ aventurar uma renovação. A liberdade de me libertar das amarras de rótulos que criei para mim. Comecei a poetizar a vida, amenizar as dores da alma e aliviar o corpo de uma bagagem tão castradora... O teatro... me faz sentir vivo, conectado com a vida de corpo e alma.." (MR).

"Por que resolvi fazer teatro? Talvez porque na prospecção de mim mesma encontrei uma menininha que um dia subiu ao palco e, para mostrar toda a sua brasilidade, encenou uma Carmem Miranda. O evento era numa escola em Konstanz, na Alemanha" (EK).

"Resolvi fazer teatro primeiro para provar que estou viva, segundo porque me desafiaram e terceiro porque aqui experimento uma liberdade sem cobranças. Aqui me sinto feliz. Me sinto renascer" (CS). 
"Fazer teatro na $3^{\underline{a}}$ idade foi algo que nunca tinha passado pela minha cabeça, mas, assim que vi a proposta, tive a certeza de que seria algo que eu gostaria de fazer. Trabalhar a sociabilidade, a comunicação, o corpo e a memória” (NR).

"Resolvi fazer teatro porque este foi sempre o sonho pra mim. Na minha infância já participava de brincadeiras de teatro. Estou feliz por ter tido esta chance” (EM).

"Procuro conhecer o que não fiz e não tive tempo antes" (MG).

“...para promover em minha vida uma melhor atividade social” (OC).

“Tem a ver com um 'espaço' a ser conquistado, próprio e isento de análises, onde eu possa me expressar livre e sendo eu mesmo, solto de pressões sociais” (CP).

Além dos depoimentos mencionados, foi solicitado a todos os participantes que relatassem por escrito "Um fato marcante na sua vida", inserido na pesquisa como instrumento de avaliação qualitativa denominado de Depoimento 2 -"Narrativas", Apêndice V página 154. Os recortes a seguir são parte integrante das respostas dos voluntários a essa proposição.

"Um fato que marcou minha vida foi o encontro... com quem casei em 22 de fevereiro de 1975. Nestes 36 anos de vida juntos pudemos viver, chorar, brigar e amar sem deixar de sermos duas pessoas envolvidas com o bem comum” (DA).

"A vida nos traz vários fatos marcantes. Escolhi um episódio que depois do nascimento dos filhos considero dos mais marcantes... Fui para a cozinha fazer café... Ouvi gritos emocionados, corri e as abracei chorando. A Ana ingressou na faculdade de artes em SP e a Amanda foi para Bauru aos 17 anos, realizar seu sonho de ser jornalista” (EM).

"O nascimento de minha filha. Foi o dia mais alegre de minha vida quando despertei no hospital e a enfermeira me trouxe uma linda menininha embrulhadinha numa manta amarela" (MDC).

Como último item da análise qualitativa, acrescentamos a disponibilidade das imagens em vídeo e fotografia registradas sobre o trabalho corporal desenvolvido com essa população da pesquisa, o G2, do projeto Só com Experiência, do Núcleo de Artes Cênicas da Estação Ciência - USP. 


\section{DISCUSSÃO}

Este estudo quali- e quantitativo, nos dois grupos de idosos com idade acima de 60 anos, buscou evidências da influência da prática artística, mais precisamente das artes cênicas, e da atividade de resgate de memória com produção escrita baseada em referências autobiográficas e literária, como fatores motivadores e promotores de melhoria na qualidade de vida por ganhos morfofuncionais e comportamentais, diretos ou indiretos.

As Informações Sociodemográficas revelaram diversas origens de nascimento dos integrantes dos grupos em observação, com maior variabilidade para aqueles pertencentes ao grupo com treinamento em artes cênicas, que incluiu também entre seus participantes, há nele um participante oriundo de outro país, Espanha. Esse fato poderia também ocorrer no outro grupo, G1, pois a cidade de São Paulo se caracteriza por receber em seu território tanto cidadãos oriundos de outros estados do Brasil como de países estrangeiros (IBGE, 2010). E, em estando aqui, a busca por integrar-se e fazer parte da sociedade os impulsiona a participar de grupos e ações de sociabilidade como essas que foram propostas por esse estudo. Assim, a presença do participante de origem espanhola não deve ser encarada como algo inusitado, mas como algo comum na composição de comunidades em São Paulo.

Quanto ao estado civil, chamou atenção o número de solteiros no grupo 1, cinco participantes, enquanto no grupo 2 é maior o número de casados, quatro. Em relação a viúvos, há certa igualdade entre os grupos, dois $(\mathrm{G} 1)$ e três $(\mathrm{G} 2)$, e apenas um individuo na situação de separado (G2). A princípio, esperaria que o grupo com treino cênico pudesse ser formado por indivíduos solteiros e separados, pois refletiria maior disponibilidade para o convívio fora do ambiente familiar, tanto para desenvolver atividades que lhes trouxessem prazer e conhecimento como a possibilidade de encontrar novos parceiros, como sugerem alguns estudos, de que o número de pessoas que se casam após os 65 anos tem aumentado a cada década (IBGE, 2008). Contudo, não foi isso o observado, pois os resultados sugerem que os participantes dos dois grupos possuem relacionamentos civis consistentes e duradouros, deixando de existir apenas por morte do companheiro ou da companheira. Mesmo com maior número de pessoas disponíveis para relacionamento nos dois grupos, somados os indivíduos solteiros e viúvos, não deixa de ser relevante a participação daqueles com situação matrimonial ainda em curso, e que o fato de ser casado não foi motivo de impedimento para vivenciar experiências fora do ambiente familiar (Cunningham \& Brookbank, 1988), e ter 
resultados positivos no âmbito familiar, sem causar constrangimentos, entre os parceiros e parentes, segundo depoimentos em entrevista de alguns participantes (Apêndice XIX , página 183):

“... hoje eu tô liberta, entendeu, me sinto em liberdade total para sair, trancar a casa, sair e vim para cá e tá aqui inteiramente sem pensar em mais nada." (voluntário 12)

\section{"Ótima, melhorou bastante." (voluntário 5)}

Quanto à formação escolar, em ambos os grupos o tempo de estudos de 13 anos ou mais supera as demais faixas, o que poderia sugerir ser esse um fator para maior predisposição de seus integrantes a uma vida mais ativa e participativa. No entanto, a presença de voluntários com baixo tempo de estudos evidenciou que a atividade se configurou em ser um ambiente democrático, que favoreceu à ânsia de participação e aquisição de novos aprendizados e interação social.

A constatação desse ambiente democrático na composição dos grupos das atividades propostas pode ser estendida ao critério da renda salarial, também. A pesquisa mostrou, com maior destaque, que 57\% dos voluntários do G1 e 40\% do G2 têm ganhos salariais entre 5-6 salários mínimos, e no entanto, houve efetiva participação de voluntários tanto com ganhos salariais abaixo dessa faixa como acima também. Outra observação importante em relação ao interesse em participar de atividades e poder aquisitivo na terceira idade pode ser verificada no item "Residência". Os resultados na Tabela 2 mostraram que mais de $70 \%$ dos participantes em ambos os grupos possuem residência própria e em torno de $14 \%$ moram em situação de aluguel e apenas $10 \%$, no $\mathrm{G} 2$, moram com familiares. O fato é que o envelhecimento há algum tempo é encarado como uma fase para novas oportunidades e o poder aquisitivo não significa impedimento para usufruir de bens e equipamentos disponibilizados a essa população (Debert, 1999; Corazza, 2001).

Por outro lado, a disponibilidade e interesse indicados para a prática e participação em atividades poderiam estar relacionados com o viver "Sozinho", como observado no item "Mora com alguém", pois os dados ali evidenciados acentuam que cerca de $70 \%$ dos participantes do grupo 1 se situam nessa categoria. Porém, apenas $20 \%$ dos participantes do grupo 2 apresentam essa condição. Estes dados sugerem que a atitude para se ter uma vida 
ativa nem sempre está atrelada à falta de companheiro ou companheira, mas recai novamente sobre a tendência de pertencer a um grupo, se inserir em novos contextos sociais e na busca por novos aprendizados (Azevedo, 2000).

É interessante observar que $86 \%$ dos participantes do Grupo 1 são aposentados, enquanto que os demais exercem funções apenas em suas próprias casas. Já os participantes do Grupo 2 apresentaram várias opções, como "Aposentado" (40\%), "Auxílio doença" (20\%) e "Pensionista", "Dona de casa", "Consultor" e "Psicólogo" (10\%). Esta situação reflete a crescente tendência mundial de atuação dessa faixa etária no mercado de trabalho, assim como ficou evidente também que, mesmo em atividade profissional, há crescente interesse dessa faixa etária por novas situações sociais e de relacionamentos em grupo (Hermógenes, 1996).

De acordo com os critérios de seleção estipulados para a formação dos grupos da pesquisa, os dados sociodemográficos revelaram que os participantes possuíam autonomia, independência e interesse por uma vida socialmente mais ativa. Em concordância com esses aspectos caracterizadores estão também as informações sobre o quanto os voluntários realizavam de atividades de lazer antes mesmo de iniciarem o treinamento nos grupos 1 e 2 desta pesquisa: média de 5,6 ( \pm 3,2) atividades (G1) e 5,3 ( \pm 2,6) atividades $(\mathrm{G} 2)$, com predominância das atividades Caminhada, Cinema, Computador, Leitura e Música. Outro aspecto importante diz respeito ao interesse que esse público mostrou ter por se manter informado ou fornecer informações, buscando meios de aprendizagem que a vida e o meio social oferecem objetivamente (Neri, 2006), propiciando assim motivação para a prática de atividades e uma vida social pautada pela interação e atuação (MS, 2007).

As Informações Sociodemográficas, foram importantes para compreender quem e de onde são, o que fazem, sentem e como vivem os voluntários dos dois grupos. Elas foram importantes também para fazer comparações com aspectos de caracterização do próprio Projeto Só com Experiência (PSCE) - pesquisa cênica para pessoas com idade acima de 60 anos, fomentador e origem desse estudo. A começar pelo público participante de suas atividades, levando em conta o início de suas práticas, em agosto de 2007, e o convívio e treinamento com mais de 150 idosos registrados desde então, que sempre teve maior participação do gênero feminino. Essa tendência foi verificada também nas amostragens das informações sociodemográficas, que, correlatamente, indicaram também baixo número de 
participantes masculinos. Há um fato, segundo dados do IBGE (2008), de que a mulher vive mais que o homem, o que poderia justificar a tendência de a participação do gênero feminino ser mais presente nas atividades propostas à faixa etária com idade acima de 60 anos. Mas se poderia creditar também essa tendência à predisposição da mulher à busca do convívio social (Neri, 2001a). Outras características similares foram detectadas em relação à idade, 69,9 ( \pm $8,6)$ no G1, e 66,6 ( $\pm 4,9)$ no G2, e altura, $155,4 \mathrm{~cm}( \pm 6,3)$ no G1 e 159,8 cm $( \pm 6,8)$ no G2, sendo essa muito próxima da média de alguns estudos disponíveis, 157,0 cm (Souza ET AL, 2013), configurando-se assim estar dentro do padrão mediano da estatura dessa população no Brasil. Já em relação ao item "Peso", as alterações morfofisiológicas reveladas entre as fases Inicial e Final do treinamento indicaram ganho de peso por parte dos integrantes do G1, enquanto que no G2 ocorreu perda, porém, foram dados estatisticamente não significantes para a pesquisa.

As discussões a seguir se referem à percepção que os voluntários tiveram em relação a sua própria saúde, seu estado físico e motor, e cognição. É preciso ter claro o que vem a ser Percepção de Saúde para a comunidade acadêmica, bem como aquela percebida pelo indivíduo (Teixeira e Neri, 2008; Trentini et al, 2006). Percepção de saúde está muito próxima e relacionada com qualidade de vida, que, segundo a Organização Mundial de Saúde, é “a percepção do indivíduo da sua posição na vida, no contexto de sua cultura e dos sistemas de valores da sociedade em que vive, e em relação aos seus objetivos, expectativas, padrões e preocupações" (Fleck et al, 1999); ou considerar a definição de saúde e de doença exclusivamente por parâmetros objetivamente verificáveis (Gomes et al, 2012), afastando ou desestimulando assim a possibilidade de expressões subjetivas. Já para a população leiga, percepção de saúde está mais para o quanto a pessoa está disposta, tem autonomia e consegue realizar suas tarefas diárias, bem como outras atividades oriundas da sua motivação, independência e otimismo sobre a própria saúde (Grupo Whoqol, 1995, Gomes et al, 2012), ou seja, ser saudável é - antes de tudo - sentir-se saudável (Gomes et al 2012 apud Giddens, 1994). Essa ambiguidade conferida ao atual momento da sociedade está de certa maneira bem clara na percepção dos participantes dos dois grupos, que se consideraram "Saudável" e estarem em plena saúde, enquanto apenas $14 \%$ dos participantes do G1 se consideraram "Doente". Entretanto, as respostas a seguir contradizem essa autoavaliação, pois quase a totalidade dos participantes de ambos os grupos responderam que usam medicamentos, apresentam limitação física e um percentual mais equilibrado (43\% [G1] e 50\% [G2]) relatou sentir dores. A resposta desses indivíduos quanto ao tempo de sono, entre seis (G1) e oito 
(G2) horas, e o fato de ambos os grupos terem relatado não dormir durante o dia reforçam sua percepção subjetiva de saudável e doente, pois se não dormem é porque estão dispostos, como alguns participantes relataram espontaneamente. É interessante observar que mesmo com essa avaliação subjetiva de saúde, os participantes da pesquisa reiteraram o fato de reconhecerem, em si mesmos, alterações naturais propiciadas pelo avanço da idade e consequente declínio funcional do organismo (Tabela 5). Quando questionados sobre como estava sua percepção de "Mobilidade física atual", os pesquisados deixaram transparecer sua consciência em relação às mudanças comportamentais em processo no seu corpo, com entre $40 \%$ e $50 \%$ das respostas destinadas a "Regular" e "Boa" em ambos os grupos. Apenas 10\% (no G2) afirmaram ser “Ótima” e 14\% (no G1) optaram por "Ruim". Esse estado de consciência quanto às condições motoras do corpo atual foi confirmado com as respostas à pergunta seguinte, sobre se a "Mobilidade mudou com a idade", em que ao redor de $90 \%$ dos participantes, nos dois grupos, confirmaram que "Sim".

As alterações percebidas quanto à memória e à atenção reiteraram o discutido no parágrafo anterior. Os percentuais atribuídos à questão "Memória atual" (Tabela 6) são muito próximos daqueles, ou mesmo idênticos aos, observados para a "Mobilidade atual", ou seja, 43\% dos participantes do G1 consideraram ser "Boa" suas condições atuais; porcentagem igual indicou ser "Regular" e os demais relataram ser "Ruim". Já no G2, as porcentagens são iguais para "Boa" e "Regular" (43\%), as demais foram destinadas a "Ótima". Curioso é observar que, para a pergunta posterior, sobre se a "Memória mudou com a idade?", contrariamente à resposta anterior, os voluntários do G1, cerca de 60\%, afirmaram que "Não", enquanto que no G2, 70\% reafirmaram que "Sim". Essa aparente contradição quanto à percepção da memória pelos integrantes dos grupos estudados também é observada em relação à "Atenção atual". No G1, os percentuais variam de 14\% para os itens "Ótimo" e "Regular", cerca de 40\% para "Boa" e os demais, 30\%, a classificaram como "Ruim", sugerindo que, para a maioria, seu estado de atenção estava normal. Porém, para a resposta "Atenção mudou com a idade", cerca de $80 \%$ afirmaram que "Sim", o que não condiz com a resposta fornecida anteriormente pela maioria. Já sobre a "Atenção atual", para o G2, 20\% a julgaram como "Ótima", 30\% como "Boa" e 50\% a classificaram como "Regular", ou seja, as respostas tiveram o mesmo percentual tanto para a situação estável como para a em declínio e de forma coerente os mesmos participantes indicaram percentual igual (50\%) tanto para "Sim" como para "Não", quando perguntado se a memória havia mudado com a idade. 
As informações sociodemográficas forneceram os dados iniciais dos voluntários, coletados no ato de sua inscrição, evidenciando assim a caracterização dos grupos estudados. Foram informações preliminares e espontâneas, não solicitadas em uma segunda etapa, o que as tornou imprescindíveis como parâmetros para os outros instrumentos de avaliação empregados nessa pesquisa, como veremos a seguir.

A atividade cênica pode ser uma ferramenta importante na promoção da autoestima, da história pessoal (Bosi, 2005) e da mudança de atitude e anatomia corporal (Keleman, 1992) e da capacidade funcional. Os resultados tanto do Projeto Só como Experiência - pesquisa cênica para pessoas com idade acima de 60 anos (observacionais) - como dessa pesquisa permitem constatar mudanças de comportamento e melhor relação com o corpo e o ambiente social. A prática cênica tem em sua essência a atividade física como recursos fundamentais para sua realização, onde a execução de movimentos corporais se faz com a finalidade de apuração da gestualidade de forma consciente e harmoniosa. É sabido que atividade física possibilita melhor desempenho e capacidade funcional (Okimura, 2005), influindo sobre vários aspectos relacionados à qualidade de vida dos indivíduos, como motivação, prazer de viver em grupo, melhor expressão gestual e intelectual, e disposição para novas iniciativas.

Como veremos a seguir, em relação aos testes de capacidade funcional aplicados por essa pesquisa a seus voluntários, os resultados indicaram melhor desempenho dos indivíduos pertencentes ao grupo 2, que realizou treinamento cênico, em comparação aos indivíduos do grupo 1, de prática autobiográfica e literária.

A aplicação do Timed Up and Go Test foi realizada de duas maneiras, com e sem dupla tarefa. Esse é um teste para avaliar a mobilidade e caracteriza-se por incluir estímulos específicos para agilidade e equilíbrio, combinados por ações cotidianas (Câmara ET AL, 2008 apud Rogers, 2003). Seus resultados indicaram mudanças em relação ao tempo conseguido entre o teste inicial e aquele pós-intervenção, com evidência de melhora na performance pelo G2. Os participantes do Grupo 1, no teste sem dupla tarefa, apresentaram aumento no tempo, em segundos, com uma variação negativa $(-0,07$ s), que contudo, estatisticamente, não foi significante, $\mathrm{p}=0,800$. Os participantes do Grupo 2, neste mesmo teste, apresentaram performance positiva, com diminuição de tempo em 0,59 segundos, porém também, estatisticamente a diferença não foi significante, $p=0,262$. Já no teste com execução de tarefa paralela, o Timed Up and Go Test, com Dupla Tarefa, ambos os grupos obtiveram 
tempos positivos em sua performance entre o teste Inicial e Final, causando relativa surpresa devido à maior complexidade de execução requerida, pois, além de executar a tarefa de levantar, caminhar e voltar a sentar na cadeira, há o falar enquanto anda (Smith, 2009). Contrariando as expectativas de maior dificuldade na execução do teste, os indivíduos do G1 fizeram o percurso estabelecido com redução de tempo em 0,20 segundos, entre o pré- e pósteste, enquanto os participantes do G2, em 0,9 segundos. Esses resultados positivos sugerem ganhos na performance física que podem refletir na melhoria da qualidade de marcha, na transferência do nível sentado para de pé e no equilíbrio (Soares et al, 2009). No entanto, em nenhum dos casos de redução do tempo médio foi detectada diferença estatisticamente significante (Tabela 7).

Para o outro teste de capacidade funcional aplicado, Six-minute Walk Test, Teste de caminhada de seis minutos (TC-6), o limite mínimo aceitável dos valores validados para pessoas idosas saudáveis é de 400 metros e máximo de 700 metros (Enright, 2003). A distância mínima percorrida pelos voluntários do G1 foi de 392,6 m, média do grupo, na primeira fase de teste, e na fase seguinte, a Final, foi de 409,1, indicando aumento na distância percorrida de $16,57 \mathrm{~m}$. Assim, o escore final conseguido pelo grupo ficou dentro do padrão de aceitação para pessoas idosas saudáveis. Já os resultados apresentados para o G2 indicam um quadro com números relativamente mais positivos: na fase Inicial, 420,0 m, e na Final, 477,90 $\mathrm{m}$, ou seja, uma diferença positiva de $57,90 \mathrm{~m}$, estatisticamente significante $(\mathrm{p}=0,006)$.

Por último, em relação aos testes de capacidade funcional aplicados, o On-leg Balance Test, nas duas fases programadas pela pesquisa, pré- e pós-treinamento, evidenciou que os valores de tempo conseguidos pelos voluntários por permanecer em equilíbrio com uma perna não chegam a apresentar alteração estatisticamente significante entre os dois momentos do teste, mesmo observadas alterações de performance entre os integrantes dos grupos $(2,97 \mathrm{~s}[ \pm$ $3,83 \mathrm{~s}]$ no G2), e $-0,02 \mathrm{~s}[ \pm 5,16 \mathrm{~s}]$ no G1). Diante do exposto, pode-se dizer que os resultados obtidos com os testes Timed Up and Go Test, Six-Minutes Walk Test e On-Leg Balance Test, de modo geral, sugerem relativa melhora de performance nos tempos alcançados entre as fases Inicial e Final, principalmente pelo G2, sugerindo assim progresso no equilíbrio (Vellas ET al, 1997), bem como de postura, movimento corporal e prevenção de quedas (Silva ET AL., 2008). No entanto, o desempenho positivo nos três testes acima não foi verificado da mesma forma nos resultados dos questionários WHOQOL-Bref e WHOQOL-OLD, como indicaram os dados que dizem respeito à capacidade funcional e sensorial, tanto na Faceta 
Funcionamento dos Sentidos (WHOQOL-OLD), quanto no Domínio Físico (WHOQOLBref), com relativa evolução positiva apenas do G1 e não do G2. O que de certa forma não era esperado, pois, como os testes de capacidade funcional evidenciaram, os participantes do treinamento em artes cênicas foram aqueles que melhor haviam respondido aos testes. Diante disso, resta buscar entender ou saber qual a fonte para tal ambigüidade nos resultados da pesquisa, tal como ser o " $n$ " amostral da pesquisa considerado baixo para esse tipo de estudo, como se pode verificar pelo próprio desvio padrão observado nas medidas. Consideração pertinente, pois, observações a partir das Figuras 11, 12, 13 e 14, mostram que há um maior número de indivíduos com valores positivos que negativos e, no entanto, tanto o Domínio Qualidade de Vida (WHOQOL-Bref) como a Faceta Global (WHOQOL-OLD) apresentaram resultado negativo entre as fases Inicial e Final, sugerindo assim que em grupos com baixo "n" amostral, quando aplicados os questionários WHOQOL-Bref e OLD, um resultado individual marcadamente negativo irá interferir sobre maneira no valor geral.

A avaliação por meio do Cambridge Cognitive Test - CAMCOG (Bottino et al, 2000) e do Mini Exame do Estado Mental - MEEM (Folstein e Folstein, 1975) apresentou resultados de quadro de estável a relativa melhora sobre os aspectos relacionados às funções cognitivas dos participantes da pesquisa, entre as aferições Inicial e Final, indicando que os indivíduos eram saudáveis quanto aos aspectos avaliados e em concordância com os critérios de seleção para composição dos grupos de estudo.

As próximas discussões se referem aos Quadros 2 e 3, e Tabelas 16, 17, 18 e 19, que apresentaram resultados apenas Inicial com o propósito de caracterizar o público da pesquisa e selecionar os indivíduos conforme os critérios estabelecidos por essa pesquisa.

A associação entre obesidade e risco cardiovascular é proporcional ao aumento da Massa corporal - IMC - (Cercato et al, 2000). Um dos fatores para ocorrência de aumento de massa corporal é sedentarismo e tabagismo, assim como o consumo de bebidas alcoólicas, principalmente entre os homens (Resende et al, 2006). Esse perfil caracterizado pelo enunciado acima não corresponde aos identificados nos participantes desta pesquisa. $\mathrm{Na}$ avaliação do perfil antropométrico e de composição em ambos os grupos da pesquisa, segundo as categorias de IMC, apesar dos indivíduos estudados não estarem com o IMC classificado como "Normal" e ausentes de risco de doença (IMC entre 18,5 e 24,9), não houve indicação alguma de casos com risco de doença "Grave" e "Muito Grave". No entanto, todos 
eles se configuram dentro das classificações "Pré-obesos" (IMC entre 25,0 - 29,9), com risco de doença "Aumentado" e "Obesos Grau I" (IMC entre 30,0-34,9), com risco de doença "Moderado".

No entanto, com base nos parâmetros indicados pela OMS, quanto à presença de "Risco Aumentado" e "Alto Risco", na Relação Cintura Quadril - RCQ - dos integrantes dos G1 e G2, foi verificado que a maioria dos participantes se enquadrou em ambas as classificações e apenas os voluntários $8(\mathrm{RCQ}=0,73)$ e $10(\mathrm{RCQ}=0,72)$, integrantes do $\mathrm{G} 1$, apresentaram medidas sem se configurar com risco de doença. Entretanto, mesmo tendo observado casos com "Alto risco" de doença, não houve registro de dificuldade que impedisse a participação nos grupos ou mesmo o desenvolvimento das práticas. Todos os voluntários se mostraram aptos às atividades propostas, o que foi comprovado no decorrer dos estudos e confirmado pelos depoimentos e respostas nos questionários de avaliação do treinamento (Escala Likert, para o G2), indicando melhoria na qualidade de movimento, postura, equilíbrio, com declarações espontâneas de diminuição de peso, como foi o caso do voluntário 12 , que iniciou a atividade com $84 \mathrm{~kg}$ e finalizou com $80 \mathrm{~kg}$.

Em relação aos exames de pressão arterial (Tabelas 18 e 19), eles revelaram que a maioria dos indivíduos de ambos os grupos teve a pressão diastólica aferida com no máximo $85 \mathrm{mmHg}$, ou seja, para todos os participantes se fez recomendável "reavaliação em 1 ano e estimular mudanças no estilo de vida" e, em relação à pressão sistólica, além desta recomendação para quatros casos (dois no G1 e dois no G2), com medidas abaixo de $130 \mathrm{mmHg}$, houve maior número de casos com recomendação para "confirmação em dois meses e considerar MAPA/MRPA" (medidas entre 140-159 mmHg), segundo parâmetros da Sociedade Brasileira de Cardiologia - SBC (V Diretrizes Brasileiras de Hipertensão Arterial, 2006). Apenas um caso, voluntário 8 (G2), se fazia recomendável a "confirmação em 1 mês e também considerar MAPA/MRPA” (medidas entre 160-179 mmHg). Assim, com exceção do participante $8(\mathrm{G} 2)$, que necessitava maior atenção sobre sua saúde, porém sem a necessidade de intervenção, todos os demais possuíam níveis de $\mathrm{mmHg}$, tanto para a pressão sistólica como diastólica, que recomendavam controle e a atitude de mudança de hábitos, fato em desenvolvimento com sua participação nas atividades propostas pela pesquisa. É consenso, hoje, que a hipertensão arterial é fator de risco para as doenças não transmissíveis (SBC, 2007 apud Brundtland, 2002), além de apresentar relação direta e positiva com o risco cardiovascular (SBC, 2007 apud Whelton et al, 2002; Yusuf et al, 2004), sendo assim 
considerado um grave problema de saúde pública em virtude da sua prevalência elevada. Apesar das atividades propostas aos voluntários por essa pesquisa não terem tido características de tratamento clínico, foram, no entanto, recursos que visaram a estimular a qualidade de vida, por meio de medidas preventivas, como a adoção de hábitos saudáveis, exercícios físicos (SBC, 2007 apud Fagard et al, 2005) e orientações relevantes quanto aos cuidados com a saúde dos seus praticantes.

Vários dos resultados dos eletrocardiogramas observados, assim como de dosagem do colesterol total, HDL-colesterol, Colesterol LDL, triglicérides, glicemia, hemograma completo, apresentaram alterações próprias da idade e sem repercussão clínica ou evidência de isquemia aguda ou outro problema clínico que contra-indicasse a participação dos voluntários nos grupos a que optaram.

As medições da Escala Likert (Figuras de 15 a 25), aplicadas ao G2 apenas na fase Final de treinamento, forneceram dados interessantes quanto à avaliação dos voluntários em relação a seu desempenho e ganho sobre aspectos funcional, motor, emocional e cognitivo. Esses dados constituíram importante fator de comparação e análise de resultados quantitativos dos outros instrumentos aplicados, como os questionários Informações Sociodemográficas, WHOQOL-Bref e OLD.

Estudos têm relacionado aspectos fisiológicos do sistema sensório-motor com o nível de controle sobre os sentidos corporais na estabilidade postural ou no equilíbrio (Fonseca et al, 2007). Em síntese, eles discutem e enfatizam a importância do envolvimento da percepção, integração e gerenciamento de estímulos sensoriais, planejamento motor e execução da postura adequada para o movimento pretendido (Souza et al, 2006), como também acentuam que as atividades físicas, mesmo quando iniciadas após os 65 anos de idade, favorecem a manutenção do status funcional, a redução de frequência de quedas e incidência de fraturas (Silva et al, 2008 ). O treinamento oferecido aos integrantes do grupo2 enfatizou essas relações na sua metodologia, que abrangeu estudos das estruturas anatômicas do corpo, exercícios físicos executados com foco na consciência corporal, com o intuito da expressão ser realizada em equilíbrio e harmonia. Esse processo empregado mostra nas Figuras 15 e 16 o quanto ele foi importante para propiciar melhor estabilidade postural e deslocamento corporal. As respostas dadas pelos participantes do treinamento cênico em relação ao seu desempenho sobre os aspectos "Postura" (Figura 15), com 75\% enfatizando alterações 
positivas em seu novo status físico, e "Movimento" (Figura 16), com 87,5\%, chamam a atenção e são compatíveis com os dados já discutidos nos testes funcionais TUTG-1 e TUTG2, TC-6 e On-Leg Balance, e comprovados também com os resultados do aspecto "Flexibilidade" (Figura 17).

O treinamento oferecido ao G2 foi desenvolvido com o interesse no conhecimento e consciência corporal, buscando o alongamento muscular e a expansão dos espaços entre as articulações (Gonçalves et al, 2011), com o objetivo de criar novas posições e posturas a fim de tornar o corpo ferramenta de expressão e criação artística. A flexibilidade, aqui, é aspecto relevante para o movimento e deslocamento, pois propicia ao corpo segurança no movimento muscular, no equilíbrio e na desenvoltura postural, caracterizando-se assim como elemento essencial de apoio à liberdade de movimento (expressão) dos indivíduos. A distribuição dos valores creditados pelos voluntários a sua flexibilidade, logo após o treinamento (Figura 18), com $87,5 \%$ de melhora, denota uma nova relação e percepção do grupo com o seu corpo, haja vista que no início da pesquisa o questionário Informações Sociodemográficas informou que $70 \%$ dos seus participantes apresentavam "Limitação Física" e 90\% relataram ter havido "Mudança na mobilidade física com a idade" (Tabelas 4 e 5, respectivamente), neste caso, com avaliação de declínio funcional.

A atenção, além de ser fundamental e altamente trabalhada no exercício cênico, é um fator importante no estabelecimento de memória (Gazzaniga, 2008) e plasticidade, colaborando para a autonomia, independência e tomada de decisão (Damásio, 2010). Os resultados apresentados pelas Figuras 18 e 19, que dizem respeito à avaliação dos voluntários do G2 sobre o aspecto "Atenção" e "Memória", respectivamente, têm os itens correspondentes no WHOQOL-OLD (“Autonomia" e "Atividades Passadas, Presentes e Futuras") também apresentando avaliação positiva entre as fases Inicial e Final e estão de acordo com os resultados obtidos pelo aspecto "Atenção" (Figura 18). Em relação à "Atenção", o percentual de avaliação positiva é ainda mais relevante quando comparado com a resposta à pergunta do questionário de Informações Sociodemográficas, sobre "Como está sua Atenção atual?" (Tabela 6): em ambos os instrumentos, 100\% dos voluntários acentuaram sua avaliação entre razoável e ótima. O que evidencia a percepção de ganho de atenção em um quadro que já se colocava com avaliação positiva.

Outro resultado que confirma a melhora de desempenho dos aspectos focalizados pelas medições da Escala Likert é o da "Memória" (Figura 19), que obteve o mesmo índice 
percentual destinado à "Atenção" (100\%). Esse dado confirma o enunciado de que a atenção é uma função que favorece ao estabelecimento de memória (Gazzaniga, 2008) e ao mesmo tempo sugere que o treinamento cênico, que em sua essência tem o uso da memória como fundamental, requer para isso muita atenção e concentração dos praticantes, o que favorece a melhor percepção sobre os aspectos envolvidos.

A motivação está relacionada à emoção e envolve necessidades e objetivos do indivíduo que influem na aprendizagem, na determinação do comportamento (Todorov e Morreira, 2005) e na qualidade de vida. A motivação e estado emocional dos participantes do G2 foram avaliados por meio da Escala Likert e apresentaram resultados amplamente positivos. O aspecto "Motivação" (Figura 20) obteve 100\% das respostas creditadas à melhora de desempenho, com 50\% destinadas à melhora Excelente. Enquanto o aspecto "Emocional" (Figura 21), também avaliado com clara percepção de melhora pelos voluntários, teve apenas $12,5 \%$ das respostas registrando que não houve melhora alguma. Esses dados, comparados ao resultado do Domínio Psicológico (questionário WHOQOL-Bref), cuja balanço entre as fases Inicial e Final também foi positivo, acentuam a concordância entre os diferentes instrumentos de avaliação aplicados e sugere a influência positiva do treinamento oferecido sobre o público desta pesquisa, com melhora da autoestima e benefícios psicológicos propiciados pela realização dos exercícios físicos, bem como redução do declínio cognitivo (Silva et al., 2008).

Os resultados apresentados e aferidos pela Escala Likert, até agora discutidos, evidenciam, de maneira geral, acentuada melhora do G2 nos aspectos avaliados. Entretanto, estes foram dados relativos apenas ao próprio indivíduo, sem a visão do grupo sobre o coletivo em treinamento ou mesmo sobre os relacionamentos fora do ambiente de pesquisa, como veremos a seguir.

A capacidade de aprender não é apenas para se adaptar, mas, sobretudo para transformar a realidade, para nela intervir, recriando-a (Okimura, 2005 apud Freire, 2002). Daí a importância de inserir métodos e pedagogias que incluam o idoso num processo de estímulo ao pensar, de estar presente e atuar socialmente, de torná-lo mais consciente da sua realidade e de se assumir enquanto ser e cidadão (Lima, 2001). Os aspectos de abordagem social, de relacionamento mútuo e em grupo, de certa forma, também foram verificados pelos instrumentos WHOQOL-Bref e OLD. Porém, ali, os dados apresentados foram distintos. Enquanto o primeiro, Bref, mostrou valor negativo na comparação entre a fase Inicial e Final, 
o segundo, WHOQOL-OLD, instrumento de aplicação específica aos idosos, foi enfático em apresentar resultados positivos. Compactuando os resultados desse último instrumento, a Figura 22 acentua o grau de relacionamento conquistado e percebido pelos integrantes dentro do próprio grupo de pesquisa, evidenciando alto índice de melhora, ao qual 100\% creditaram mudanças de boa a excelente. Essa percepção de melhora sobre o relacionamento é confirmada também pelos resultados apresentados na avaliação de desempenho no relacionamento de âmbito familiar (Figura 23). Mesmo sem a totalidade das repostas indicar os critérios com melhor avaliação, o percentual de $87,5 \%$ mostra o quanto o grupo assimilou da qualidade de relacionamento adquirido entre e com os companheiros do grupo, estendendo esse ganho para o contato e convivência com os parentes, confirmado também pelos depoimentos dos voluntários fornecidos à equipe de pesquisa. Essa situação positiva sobre os aspectos trabalhados também se repete na avaliação feita para medir o grau de evolução no relacionamento com os amigos, fora do ambiente da pesquisa (Gráfico 24), e que, de certa forma, reflete a melhor percepção dos voluntários sobre si mesmo e o nível da qualidade de vida adquirido naquele momento.

De maneira geral, esses três aspectos discutidos - relacionamento dentro grupo, relacionamento em ambiente familiar e relacionamento com amigos, fora do ambiente de treino - confirmam o resultado positivo obtido pela Faceta Participação Social (WHOQOLOLD), que apresentou a pontuação Inicial de 66,25 e Final de 72,50, e evidencia que, quando há incentivo à pratica física, bem como cognitiva, de forma planejada e contínua aos idosos, à troca de experiências e o prazer do convívio em grupo favorecem ao aprendizado e contribuem para melhor percepção sobre aspectos sócias, inclusive no relacionamento familiar (Okimura, 2005).

Por fim, o último gráfico a ser discutido, Figura 25, gerado pela Escala Likert, tratou da autoavaliação em relação à Saúde dos participantes do G2.

A saúde da pessoa idosa está muito associada ao conceito de envelhecimento ativo, termo que passou a ser utilizado pela Organização Mundial da Saúde (OMS) a partir da década de 1990 (MS 2007). Mas o que significa se incluir no conceito de "envelhecimento ativo"? Não há, de certo, uma regra específica, mas entre outros aspectos ele reflete o grau de ações e de inclusão que o indivíduo idoso tem, de oportunidades de saúde, participação e segurança, que refletirão em sua autonomia e independência. No envelhecimento ativo, 
práticas de atividades físicas cotidianas e de lazer são alguns dos itens recomendados pela OMS para promoção do bem-estar e de melhor qualidade de vida, à medida que o processo de senescência se desenvolve. O treinamento cênico oferecido aos integrantes do G2 dessa pesquisa se insere nesse contexto, com oferta de atividade física e de lazer, conforme proposta da OMS. A percepção de saúde dos voluntários após o treinamento oferecido, evidencia evolução positiva de bem-estar e saúde. Esse resultado sobre o aspecto avaliado, "Sáude", é muito importante, pois ele representa a síntese dos demais resultados medidos pela Escala Likert, e ainda confirma os resultados positivos de outros instrumentos aplicados de avaliação sobre os aspectos cognitivos e motores (CAMCOG, WHOQOL-OLD, TUGT (1 e 2), TC-6, One-Leg Balance Test), bem como os narrados em depoimentos. Juntos, eles evidenciam o alcance dos objetivos propostos nesta pesquisa, mesmo com ressalvas ao "n" utilizado e à duração do experimento.

É importante reiterar que não se pode deixar de creditar méritos e créditos ao método qualitativo, embora, ainda haja certa resistência quanto a seu uso em pesquisas. Vale ressaltar que, nela, a presença do pesquisador no ambiente em que se desenvolve o estudo, torna sua preocupação com o processo maior do que com o produto (Bogdan \& Biklen, 1994). Segundo Minayo, o método qualitativo é capaz de incorporar a questão do significado e da intencionalidade como inerentes aos atos, às relações e às estruturas sociais, sendo essas últimas tomadas tanto no seu advento quanto na sua transformação, como construções humanas significativas (Minayo, 1996). No que concordam os achados que definem o método qualitativo como aquele que se preocupa com o universo de significados, como o ponto chave para revelar importantes informações sobre o sujeito da pesquisa, seu modo de vida e relações interpessoais (Gomes, 2011).

A prática das artes cênicas, como realizado nesta pesquisa, por sua força expressiva, sua comunicação ao vivo (Matos e Silva, 2003) seu espaço para criatividade permanente, sua aceitação e consciência entre o eu e seu duplo (Artaud, 2006); pela sua tradução de emoções e pensamentos em palavras e desenhos corporais, bem como pela transferência desses estados de atenção para o cotidiano, para o extra-palco, ofereceu possibilidade concreta de recursos e meios aos praticantes de se situarem em seu processo de envelhecimento de forma consciente, considerando sua jornada de vida digna, humana e natural. Assim, o potencial criativo em recrutamento constante faz das artes cênicas uma prática, embora não única nem isolada, valiosa para trabalhar as interações intra e extra-pessoais de seus praticantes. 
Os registros narrativos documentados pelo formulário denominado Depoimento 1 evidenciaram um apelo do grupo à realização de algo pessoal, não realizado anteriormente, que foi abandonado ou postergado por fatores externos: familiares, sociais, culturais etc.

Foi observado, de forma geral e pelas avaliações, certo grau de arrependimento, uma frustração velada ou ainda inconsciente, não demonstrada, guardada em si mesma. Um sentimento de desejos reprimidos, do esconder-se para que o outro apareça e de possibilidades não realizadas. Não que estes sentimentos representem patologias evidentes. Não. Na maioria dos casos, é percebida clara aceitação, apesar de dolorida, de que aquela fase foi consciente e "necessária", principalmente na composição de famílias ou por questões de trabalho. Por outro lado, aquelas dificuldades motivadas por reações culturais ou preconceituosas representam situações mais incômodas, com maior dificuldade de aceitação. Outros fatores importantes relatados nesses depoimentos foram: o querer fazer algo diferente do já realizado, corriqueiro e cotidiano; ou, ainda, o desejo de atividades que "preencham o tempo" e propiciem condições e oportunidades para criar novos laços, amizades e afeto. Porém, em todas as circunstâncias relatadas, foi possível vislumbrar o desejo de mudança, de experimentar algo novo, de deixar de lado o inconformismo com a situação ou fatos ocorridos, geradores de sentimentos arraigados de rejeição, abandono, inutilidade, e assim realizar algo novo e pessoal. Nesse sentido, ao se colocarem disponíveis para a atividade, torna-se claro o forte desejo de realizar "aquilo que mais queriam" e que as circunstâncias da vida não permitiram.

Os jogos e as improvisações com foco na formação educativa dos voluntários representaram um lugar comum e referência para o trabalho de integração e introdução ao fazer cênico. Isso foi ilustrado em uma das primeiras gravações em vídeo do G2, o registro de um desses exercícios de palco, o qual pode ser considerado uma releitura da "Caminhada no Espaço" (variações 1, 2 e 3, de Spolin, 2008), mas também uma aplicação do "Dezesseis temas de movimentos básicos" (Laban, 1990), de deslocamento pelo espaço, buscando preencher os lugares vazios, sentir seu corpo no espaço e suas articulações em movimento. Nas imagens gravadas, ficou visível o quanto os sentimentos estão presentes nas ações corporais dos voluntários. Os participantes, ao ouvirem as palavras de comando "preencham os espaços vazios", “ocupem os lugares" etc., seguiam as orientações, porém com a cabeça baixa e sem o tônus necessário para expressar o encontro dos objetivos traçados para aquele 
momento, ou seja, deslocar-se pelo espaço atentamente. Segundo Courtney (2006), o homem é um fazedor de ritos, mas quem criou os ritos foi o homem caçador. Ao aplicar esse exercício, a atitude de muitos dos participantes revelou expressão corporal justamente oposta ao que Courtney afirmara, ou seja, com ausência de atitudes e estado de atenção característicos ao ato de celebração, de compreensão daquilo que contém o germe de todo rito e de toda linguagem do "ser caçador". A cabeça baixa, os olhos direcionados para o solo, os passos lentos e a falta de comprometimento com a busca de novos espaços indicava vários fatores a serem trabalhados e revelavam certa inadequação ou desconhecimento da proposta iniciada, o que, conseqüentemente, induzia certa inibição. Porém, é possível entender que a falta de crédito no rito, o fato do indivíduo não se sentir em condições de buscar sua própria sobrevivência, de pensar que não merece ser alimentado sejam os fatores geradores daquelas atitudes, quadro este de sentimentos totalmente opostos ao objetivo desta pesquisa. $\mathrm{O}$ teatro exige rito, presença, atitude de sobrevivência constante, acreditar e fazer, transformar situações. À medida que o exercício se repetia no decorrer da pesquisa, as mudanças desejadas ocorreram, ao passo que foram repetidas novas vozes de comando, tais como "sejam caçadores e não caça", "olhem para o horizonte", "inspirem-se nos felinos", a postura foi sendo modificada e as respostas corporais, buscadas, foram sendo obtidas (Lowen, 1982).

Ao desenvolver a pesquisa com o G2, especificamente, os exercícios cênicos buscaram enfatizar as observações na qualidade expressiva dos corpos dos voluntários, como sua interrelação com o grupo. Chegou-se mesmo a usar a expressão como "andem com o olhar de caçador, olhando o horizonte, e não de caça, para o chão", para testar a motivação e atitude dos integrantes do grupo. Isto por ter sido verificada, principalmente no início da atividade, a expressão contida e tímida de muitos deles, com olhares para o chão, cabeça baixa, coluna em curva, omissão de iniciativas verbais entre outras manifestações corporais limitadoras. Porém, ao ser usada repetidas vezes essa expressão verbal, ficou evidente o quanto os participantes do grupo modificavam a postura e envolvimento com a atividade, reiterando assim a sua importância sobre o estado funcional da ação corporal. Ao propiciar essa modulação consigo, o corpo também estará mais atento e aberto a compreender o outro e assim a comunicação terá maior grau de eficiência.

Assim, aos voluntários do G2, foi incentivada a tomada de consciência e foco sobre sua história, as experiências que cada um desses corpos traz em si e o desejo de se acrescentar ainda mais capítulos a essa obra, o corpo cênico, em constante construção. Ao buscar interagir 
com esses "universos", além dos depoimentos mencionados, foi solicitado a todos os participantes que relatassem por escrito "Um fato marcante na sua vida", que foi inserido na pesquisa como instrumento de avaliação qualitativa denominado de "Narrativas". Esse instrumento rico em sentimentos e veracidade compôs, também, os textos de referência para o trabalho cênico, transformado em espetáculo, cujo intuito foi oferecer aos participantes a oportunidade de relatar suas histórias, como forma de resgate de memória, ou criar um ambiente para módulos terapêuticos. Mas, ao estar lidando com novos ambientes, palavras, gestos e linguagem, lhes possibilitar um recurso de iniciação cênica baseada no que lhes é conhecido, vivenciado, identificável nas suas criações artísticas, sem exigir esforços cognitivos além do necessário para o momento, ou seja, espontaneamente e sem tentativas de leituras e memorização de textos de outras pessoas. O que nos pareceu adequado diante da atividade que estava se tornando conhecida somente naquele momento. Os recortes das "Narrativas" confirmaram a contribuição dessa reflexão ao mesmo tempo em que revelaram o que havia de potencial cênico a ser explorado no palco por aquele grupo.. Assim foi também enriquecido o aspecto emocional da atividade.

"Temos necessidade de um símbolo autêntico da visão interna que efetue contato com o
público e ele só é alcançado quando se aprendeu a raciocinar em termos de movimento. o
problema fundamental do teatro é aprender como usar esse tipo de pensamento com o
propósito de atingir o domínio do movimento." (Laban, 1978).

Segundo, John McCrone (2007), a finalidade do cérebro é otimizar comportamentos. No entanto, como vimos nas análises anteriores, estamos lidando com uma população com sistemas fisiológicos, morfológicos, imunológicos e endócrinos em declínio, sendo o cérebro o próprio objeto de identificação de deficiências nessa população. Então, como ele pode ser o grande preservador do corpo (Damásio, 2011) e otimizador de comportamentos? Ao cérebro é dado o privilégio de criar novas memórias e com elas novas atitudes e comportamentos. Nos estudos do Keleman (1992), a anatomia atual do corpo é vista como forma última das histórias emocionais criadas e geradas durante toda uma vida e, se assim o é, ele é também uma possibilidade constante de mudanças. Seu destino não é algo definido anteriormente e estabelecido por critérios alheios à ação do indivíduo sobre si mesmo. Portanto, é uma história em constante transformação, que pode enfatizar ainda mais a forma que se lhe apresenta naquele momento ou obter outra diferente. Ao refletir sobre os estudos de William James 
sobre as emoções, António Damásio define o que veio a chamar de "marcadores somáticos" da seguinte maneira:

"O que permite que a mente saiba que esses domínios existem e pertencem a seus proprietários - corpo, mente, passado e presente e todo o resto - é que a percepção de qualquer um desses itens geradores de emoções e sentimentos e, por sua vez, os sentimentos, ensejam a separação entre os conteúdos que pertencem ao Self e os que não pertencem. De minha perspectiva, esses sentimentos funcionam como marcadores. São os sinais baseados em emoções que chamo de marcadores somáticos" (Damásio, 2011).

Diante de tais argumentos e afirmações, é possível observar o quanto as emoções são importantes para o corpo e sua expressividade, física e mental. As imagens, vídeo e fotos, revelaram como os corpos dos voluntários chegaram ao início da pesquisa. Em muitos casos, eram corpos curvados, sem tônus, com movimentos em desarmonia ou sem fluidez, que, apesar da maturidade de seus órgãos e da perda de capacidade natural de suas funções, sugeriam ser também resultados de tensões e embates entre o que se quer e aquilo que se fez ou faz, entre o que se deseja e o que está sendo disponibilizado, entre a busca de afeto e o abandono ou mesmo o descaso oferecido, corroborando o que foi observado nos instrumentos de avaliação descritos: Depoimento 1, Narrativas e os jogos aplicados. Por outro lado, são corpos cúmplices da própria história da humanidade (Feldenkrais, 1977), carregando consigo informações, realizações, experiências individuais únicas e divididas com o tempo. Histórias formuladas para sobreviver, criar, compartilhar, integrar, superar desafios e obrigações, que experimentaram momentos de paz, tranquilidade, como também de inquietudes e desabafos. Portanto, corpos de histórias, fontes de criação e potencialidade artística, germe e alimento para todo o processo cênico necessário, mas também possibilidades de mudanças comportamentais. Assim, foram utilizados os conteúdos teóricos e exercícios práticos presentes nas técnicas corporais de estudo do movimento consciente, com o objetivo de preparar esses corpos para a compreensão da espacialidade, tempo, ritmo, força, impulso e equilíbrio, onde o fundamental foi trazer a percepção física, presente no aqui e agora, com referências desenvolvidas por Moshe Feldenkrais (1997), Rudolf Laban (1978 e 1990) e Klauss Vianna (2005). O estar presente para responder aos estímulos provocados pelas situações cênicas ou mesmo pelo próprio corpo, internamente. $\mathrm{O}$ ato exploratório do movimento consciente nos leva a descobertas corporais próximas, como também daquelas que pareciam não existir ou mesmo serem possíveis de realizar. É essa possibilidade de alcançar 
novas fronteiras ou ultrapassar certos limites corporais que o torna um mecanismo de aperfeiçoamento qualitativo e de conquista quantitativa de execução expressiva de movimentos. Assim "o homem demonstra, por intermédio de seus movimentos e ações, o desejo de alcançar certos fins e objetivos" (Laban, 1978). E os fins e objetivos no palco são mover-se com consciência para dar sentido ao jogo ficcional ali colocado, buscando, antes de tudo, a execução do movimento com segurança e harmonia, atento aos estímulos e às possibilidades de se criar uma dramaturgia corporal espontânea, livre e pessoal. As imagens em vídeo e fotos disponíveis à verificação sugeriram que o trabalho desenvolvido propiciou a esses corpos pesquisados o enfrentamento ou o ir ao encontro de seus próprios traumas, repressões, opressões, angústias, conflitos, alegrias, sonhos, desejos, superações abertamente visíveis ou disfarçadamente encobertos, o que visivelmente modificou postura, marcha, equilíbrio, força muscular e resposta ao movimento solicitado e propiciou ganhos observáveis em corpos com tônus e objetividade, cênica e socialmente.

Portanto, diante da inexorabilidade do ser vivo envelhecer ao longo de sua existência e da constatação da crescente população de idosos no mundo, e em particular no Brasil, para o qual se estima em 2050 (IBGE, 2008) 22,71\% da população com idade acima de 65 anos, este estudo buscou avaliar alguns recursos e procedimentos quanto à melhoria de qualidade de vida e consequentes observações sobre as funções e capacidades funcionais e cognitivas dessa faixa etária. Com foco nas áreas de Neurociências, Artes e Saúde, se buscou compreender a dinâmica de alguns parâmetros físicos e comportamentais dessa faixa etária, assim como verificar sua influência na superação de desafios sociais, conflitos emocionais e eventuais ganhos funcionais. Os relativos resultados positivos em ambos os grupos estão de acordo com estudos que enfatizam a associação entre as práticas física e intelectual, e aquisição de novos conhecimentos e aprendizagens, com maior autonomia e habilidade social para solução de problemas por parte dos idosos (Goldstein,1995; Okimura, 2005, Shephard, 2003; Colcombe et al, 2004). O Ministério da Saúde brasileiro atribui benefícios biológicos, psicológicos e sociais à atividade física/corporal (MS, 2007). Assim, o efeito do treino com idosos pode resultar em amplas e positivas alterações tanto funcionais como comportamentais, em concordância com estudos que sugerem que a plasticidade é uma possibilidade presente e pode ser exercitada mesmo em idosos (Valentijn, 2005; Neri, 2006). Segundo Gazzaninga (2008), o treino cênico requisita maior grau de atenção de seus praticantes, permitindo haver ampla repercussão de melhora em áreas cognitivas, inclusive da memória. 
A literatura acentua ser característico do envelhecimento o declínio natural das funções e habilidades dos indivíduos. No entanto, essa mesma literatura assegura a possibilidade de criar estratégias compensatórias (Neri, 2006) para melhoria das capacidades físicas e intelectuais em idosos. Esse estudo, cuja linha de pesquisa temática é Desenvolvimento e Plasticidade, buscou identificar a afirmação de que, segundo Keleman (1992), a vida, em todos os níveis, é um processo em permanente construção e desconstrução, em que a história e experiências vivenciadas são os elementos essenciais para a construção e transformação subjetiva e corporal do indivíduo. Assim, diante do que foi disponibilizado aos voluntários dessa pesquisa, por meio de atividades até então inéditas para eles, há a evidência de que o treino, imbuído de novas aprendizagens e aplicado de forma sistemática, é fator preponderante para promover uma vida saudável e em equilíbrio com os limites e declínios que o envelhecimento implica. Além de acentuar que ganhos comportamentais e funcionais são possíveis em qualquer idade, por meio da neurogênese e do estabelecimento da plasticidade comportamental e biológica que refletem reorganização neural (Argimon et al, 2004). 


\section{CONCLUSÕES}

A caracterização dos componentes do estudo revelou serem essencialmente mulheres, cuja média de idade foi 66 (G1) e 69 (G2) anos. Na maioria, atuais moradores da cidade de São Paulo, porém originários de outras localidades. Identificaram-se como pessoas independentes, autônomas, praticantes de atividades sociofisicoculturais e preocupadas com sua saúde e participação sociocultural.

Os exames clínicos iniciais indicaram condições normais à essa faixa etária sem restrições em nenhum dos grupos à prática das atividades propostas.

As condições cognitivas dos voluntários evidenciaram tendência de evolução positiva quanto à memória e aprendizagem em ambos os grupos.

No grupo de artes cênicas houve resultados positivos quanto ao deslocamento corporal, movimento, postura e equilíbrio com consequente e declarado ganho comportamental (autovalorização e maior integração social).

A percepção inicial da qualidade de vida autoavaliada apresentou pontuação acima da média e praticamente não se modificou ao final do estudo (Whoqol-old e brief). Entretanto, a disponibilidade do grupo de teatro a autoavaliações posteriores e depoimentos, revelou ganhos emocionais, cognitivos, funcionais e de sociabilidade.

Por fim, embora o estudo tenha evidenciado a necessidade de uso de um numero amostral maior, assim como acompanhamento das atividades por período mais amplo, os dados obtidos permitem concluir que as atividades oferecidas aos dois grupos de idosos pesquisados constituem recursos efetivos à melhor qualidade de vida (aspectos cognitivos e emocionais). Bem como, por seus resultados positivos, esse estudo valida a prática em artes cênicas como proposta de atividade promotora de motivação e sociabilidade em pessoas com faixa etária acima de 60 anos de idade, e, principalmente, por trabalhar aspectos motores do deslocamento, postura e equilíbrio corporais, que além de promoverem saúde, adquirem função preventiva à quedas. 


\section{REFERÊNCIAS BIBLIOGRÁFICAS}

AACVPR Guidelines for cardiac rehabilitation and secondary prevention programs. $4^{\mathrm{a}}$ ed. Champaing: Human Kinetics, 2004;

ALEXANDRE, T. S, CORDEIRO, R. C, RAMOS, L. R. "Factors associated to quality of life in active elderly." Rev. Saúde Pública; 43 (4): 613-21, 2009.

ANTONIO, V. E.; COLOMBO, M. M.; MONTEVERDE, D. T.; MARTINS, G. M.; FERNANDES, J. J.; ASSIS, M. B.; BATISTA, R. S. "Neurobiologia das emoções.” Rev. de Psiquiatria Clínica. Vol. 35 nº 2. São Paulo, 2008.

ARGIMON, IIL; STEIN, LM; XAVIER, FMF; TRENTINI, CM. "O impacto de atividades de lazer no desenvolvimento cognitivo de idosos." Revista Brasileira de Ciências do Envelhecimento Humano. 1(1):38-47, 2004.

ARTAUD, Antonin. Linguagem e vida. São Paulo: Perspectiva, 1995.

ARTAUD, Antonin. O teatro e seu duplo. $3^{3}$ ed. São Paulo: Martins Fontes, 2006.

AZEVEDO, J.R.D. "Saúde e qualidade de vida na terceira idade". Revista Jovem Médico, Edição Especial, 2000. p. 39-42.

BALL, D.; COURY, L. Para trás e para frente: um guia para leitura de peças teatrais. São Paulo: Perspectiva, 2006;

BASTING A. D. "Arts in Dementia Care: 'This is not the end... it's the end of this chapter'." Generations. 2006; Vol. 30, 16-20;

BEAR, Mark F, CONNORS, Barry W, PARADISO, Michel A. Neurociências Desvendando o sistema nervoso. $3^{\mathrm{a}} \mathrm{ed}$. Porto Alegre: Artmed Ed., 2008;

BERTHOLD, Margot. História mundial do teatro. 3ํㅡㄹ ed. São Paulo: Perspectiva, 2010; 
BESSON M.; SCHON, D. "Comparison between language and music.” Annals of the New York Academy of Sciences - Biological Foundations of Music - 232-258 - 2001, versão online 2006;

BHATNAGAR, S. Neurociência para o estudo dos distúrbios da Comunicação. $2^{a}$ ed. Rio de Janeiro: Guanabara Koogan, 2004;

BLAKESLEE, S. “Cells That Read Minds”. New York Times; 2006.

BOAL, A. Jogos para atores e não atores. Rio de Janeiro: Civilização Brasileira, 1998.

BOHANNON, R. W. "Reference Values for The Timed Up and Go Test: A Descriptive Meta-Analysis." Journal of Geriatric Physical Therapy, 2006, vol. 29, nํㅡ 2, pp. 64-68.

BOGDAN, R.; BIKLEN, S. "Características da investigação qualitativa." In: Investigação qualitativa em educação: uma introdução à teoria e aos métodos. Porto: Porto Editora: 1994, pp. $47-51$.

BOSI, Ecléa. Memória e Sociedade: Lembranças de Velhos. 13ª ed. São Paulo: Companhia das Letras, 2005.

BOTTINO, C. M. C.; STOPPE JR., A; SCALCO, A. Z.; FERREIRA, R. C. R.; HOTOTIAN, S. R.; SCALCO, M. Z. "Validade e confiabilidade da versão brasileira do CAMDEX." Arq. Neuropsiquiatria. 2001; 59 (supl. 3): 20.

BRANDÃO, SILVA J. “Lazer para o idoso ativo como fator de qualidade de vida no processo de envelhecimento.” 2009. 191f. Tese (doutorado) apresentada ao Programa de Pós-graduação em Gerontologia Biomédica, Pontifícia Universidade Católica do Rio Grande do Sul, Porto Alegre, 2009;

BRITTNER, V.; WEINER, D. H.; YUSUF, S.; ROGRES, W. J.; MCINTYRE, R. M.; BANGDIWALA, S. I.; et al. "Prediction of Mortality and Morbidity With a 6-Minute Walk Test in Patients With Left Ventricular Dysfunction”. JAMA - The journal of the American Medical Association. 1993, 270: 1702-1707; 
BRITTO, R. R.; SOUSA, L. A. P. "Teste de caminhada de seis minutos - uma normatização brasileira.” Fisioterapia em Movimento, Curitiba, v. 19, nº 4, p. 49-54, 2006.

BROOK, Peter. O teatro e seu espaço. Petrópolis: Vozes, 1970.

BROWN, S.; PARSONS, L. "The Neural Basis of Human Dance." Cerebral Córtex. San Antonio, v. 16, Ago. 2006.

BRUNDTLAND, G. H. "From the World Health Organization. Reducing risks to health, promoting healthy life". JAMA - The Journal of the American Medical Association. 2002: 288:1974.

CALVO-MERINO, B.; JOLA, C.; GLASER, D. E. \& HAGGARD, P. "Towards a sensorimotor aesthetics of performing art." Consciousness and Cognition. 17 (3), 911-922, 2008.

CÂMARA, F. M., GEREZ, A. G., MIRANDA, M. L. J., VELARDI, M. "Capacidade funcional do idoso: formas de avaliação e tendências". Acta fisiátrica; 15(4): 249-256, dez. 2008.

CAMPOS, C. J. G. Metodologia qualitativa e método clínico-qualitativo: um panorama geral de seus conceitos e fundamentos. Disponível em www.se.pq.org.br - consulta 2011;

CARDOSO, A. S; JAPIASSU, A. T.; CARDOSO, L. S.; LEVANDOSKI, G. "O processo de envelhecimento do Sistema Nervoso e possíveis influências da atividade física". Publ. UEPG Ciên. Biol. Saúde, Ponta Grossa, 13 (3/4): 29-44, set/dez. 2007.

CAVANAGH, Patrick. "The artist as neuroscientist". Nature 434, 2005.

CERCATO, C., SILVA, S., SATO, A., MANCINI, M., HALPERN, A. "Risco cardiovascular em uma população de obesos". Arq. Brás. Endocrinol. Metab. vol.44 no.1 São Paulo Feb. 2000. 
CHACHAMOVICH E., FLECK M. P. A. Manual WHOQOL-OLD (Versão em português). 2005 .

CHACRA, S. Natureza e sentido da improvisação teatral. $2^{\mathrm{a}}$ ed. São Paulo: Perspectiva, 2010.

CIPRIANO JR, G.; YURI, D.; BERNADELLI, G. F.; MAIR, V.; BUFFOLO, E.; BRANCO, J. N. R. “Avaliação da segurança do teste de caminhada dos 6 minutos em pacientes no prétransplante cardíaco.” São Paulo. Arquivos Brasileiros de Cardiologia, 2009: vol. 92, no 4.

CORAZZA, MA. Terceira Idade \& Atividade Física. São Paulo: Phorte Editora: 2001.

COURTNEY, Richard. Jogo, teatro \& pensamento. $3^{\mathrm{a}}$ ed. São Paulo: Perspectiva, 2006.

CUNNINGHAM, W.R., BROOKBANK, J.W. Gerontology. New York: Harper \& Row, 1988

CURY, Vera. "A neurociência e o ensino e aprendizagem das artes." In: IV Simpósio Internacional de Cognição e Artes Musicais, 2008, São Paulo. Cognição Musical: aspectos Multidisciplinares. São Paulo: Departamento de Linguística FFLCH/USP, maio 2008.

DAMÁSIO, A. R. O erro de Descartes. 2ª ed. São Paulo: Cia. das Letras, 1996.

DAMÁSIO, A. R. E o cérebro fez o homem. São Paulo: Cia. das Letras, 2011.

DAMÁSIO H, GRABOWSKI T, FRANK R, GALABURDA A.M, DAMÁSIO A.R. "The return of Phineas Gage: The Skull of a famous patient yelds clues about the brain." Science, 1994: 264. 1102-5.

DAMÁSIO A.; TRANEL, D.; DAMÁSIO, H. "Somatic Markers and the Guidance of Behavior: Theory and Preliminary Testing."In:Frontal Lobe Function and Dysfunction. Edited by S. Levin, H.; Eisenberg, H. M.; Benton A. L. New York , Oxford University Press; 1991:217-229; 
DA ROSA, Sanny S. Construtivismo e mudança. São Paulo: Editora Cortez, 2002.

DARWIN, Charles. A expressão das emoções no homem e nos animais. São Paulo: Companhia das Letras, 2000.

DEBERT, GG. A reinvenção da velhice: socialização e processos de reprivatização do envelhecimento. São Paulo: Edusp: 1999.

DEMERS C.; MCKELVIE R. S.; NEGASSA H.; YUSUF, S. "Reliability, validity and responsiveness of the six-minute walk test in patients with heart failure." Am. Heart Journal 2001, 142: 698-703.

DESCARTES, R. Meditações metafísicas. São Paulo: Martins Fontes, 2000.

DYCHTWALD, Ken. Corpomente. São Paulo: Summus, 1984.

ENRIGHT P. L.; SHERRILL D. L. "Reference equations for the six-minute walk in healthy adults." Am. J. Resp. Crit. Care Med. 1998, 158: 1384-1387.

ENRIGHT P. L. “The Six-minute Walk Test.” Respiratory Care. 2003, Vol. 48 no 8.

FAGARD, R.H. "Physical activity, physical fitness and the incidence of hipertension". J. Hipertens 2005:23:319-327.

FELDENKRAIS, Moshe, Consciência pelo movimento. São Paulo: Summus, 1977.

FLECK, M. P. A.; LOUZADA, S.;XAVIER, M.,; CHACHAMOVICH, E.; VIEIRA, G.; SANTOS, L.; et al. "Aplicação da versão em português do instrumento de avaliação da qualidade de vida WHOQOL-100.” Rev. Saúde Pública 1999; 33(2): 198-205.

FLECK, M. P. A.; LOUZADA, S.; XAVIER, M.; CHACHAMOVICH, E.; VIEIRA, G.; SANTOS, L.; et al. "Aplicação da versão em português do instrumento abreviado de avaliação da qualidade de vida WHOQOL-bref.” Rev. Saúde Pública, 2000; 34 (2): 178-183. 
FLECK, M. P. A.; CHACHAMOVICH, E.; TRENTINI, C. M. "Projeto WHOQOL-OLD: Método e resultados dos grupos focais no Brasil." Rev. Saúde Pública, 2003: 37(6).

FLECK, M. P. A.; CHACHAMOVICH, E.; TRENTINI, C. M. "Desenvolvimento e validação em português do módulo WHOQOL-OLD.” Rev. Saúde Pública, 2006.

FOLSTEIN, M. F.; FOLSTEIN, S. E.; MCHUGH, P. R. "Mini-Mental State: a practical method for grading the cognitive state of patients for the clinician. J. Psych Res. 1975.

FONSECA, M.C.R., FERREIRA, A.M., HUSSEIN, A..M. "Sistema sensório-motor articular: revisão da literatura". Fisioterapia e pesquisa, 2007; 1 4(3):82-90.

FREIRE, P. Pedagogia da autonomia: saberes necessários à prática educativa. São Paulo: Paz e Terra, 2002.

GAZZANIGA, M. (org). Learning, Arts and the Brain. The Dana Consortium Report on Arts and Cognition. Dana Press, Nova York, D.C., 2008.

GEERTZ, Clifford. O saber local: novos ensaios em antropologia interpretativa. Petrópolis: Vozes, 1997.

GIL, J. Movimento total. São Paulo: Ed. Iluminuras, 2004.

GIDDENS, A. Modernidade e identidade pessoal. Oeiras: Celta Editora, 1994.

GOLDSTEIN, L. L. "Estresse, enfrentamento e satisfação de vida entre idosos: um estudo do envelhecimento bem-sucedido." [tese]. Campinas (SP): Universidade Estadual de Campinas; 1995.

GOMES, I., MARQUES, A.M., FERNANDES, A. “ 'Ter Saúde' na última fase da vida: lógicas do saber leigo" In VII Congresso Português de Sociologia. Universidade do Porto, 2012. 
GONÇALVES, L.C., VALE, R.G.S., BARATA, N.J.F., VAREJÃO, R.V., DANTAS, E.H.M. "Flexibility, functional autonomy and quality of life (QoL) in elderly yoga practitioners". Archives of Gerontology and Geriatrics, Volume 53, Issue 2, September 2011, Pages 158-162.

GUYTON, A. C. e HALL, J. E. Tratado de fisiologia médica. $10^{\mathrm{a}}$ ed. Rio de Janeiro: Guanabara Koogan, 2002;

HAGENDOORN, Ivar. "Some Speculative Hypotheses about the Nature and Perception of Dance and Choreography." Journal of Consciousness Studies, v.11, nº 3-4, 2004.

HEINES, D. E. Neurociência fundamental para aplicações básicas e clínicas. $3^{\mathfrak{a}}$ ed. Rio de Janeiro: Elsevier, 2006.

HELENE, A. F.; XAVIER, G. F. “A construção da atenção a partir da memória.” Rev. Bras. Psiquiatria. 2003: 25 (Supl II): 12-20;

HERCULANO-HOUZEL, S. O cérebro nosso de cada dia. Rio de Janeiro: Editora Vieira \& Lent, 2003.

HOUZEL, Herculano S. "Cognição e consciência: história e perspectivas, do cérebro ao corpo.” Neurociências, v. 2, n⿳ำ 4, 2005.

HUIZINGA, Johan. Homo ludens. São Paulo: Perspectiva, 2001.

IBGE - Instituto Brasileiro de Geografia e Estatística (BR) . Disponível no site http://www.ibge.gov.br/home/estatistica/populacao/censo2010/ . Consulta em dexembro de 2012

IBGE - Instituto Brasileiro de Geografia e Estatística (BR). Projeção da População do Brasil por Sexo e Idade - 1980-2050. Rio de Janeiro, 2008.

IBGE - Instituto Brasileiro de Geografia e Estatística (BR). Perfil dos Idosos Responsáveis pelos Domicílios no Brasil - 2000. Rio de Janeiro, 2002. 
JAMES, W. Attention. The Principles of Psychology, Vol. 1 (pp. 402-458). Nova York: Dover Press, 1890, 1950.

JOHNSON, M.The Meaning of the Body: Aesthetics of Human Understanding. Chicago: The University of Chicago Press, 2007.

EANNEROD, Marc. Motor cognition: What actions tell the self. 3‥ ed. Nova York: Oxford University Press, 2008.

KANDEL, E.R. - Princípios da Neurociência. São Paulo: Editora Manole, 2003;

KANDEL, E. R. - Em busca da memória - O nascimento de uma nova ciência da mente. São Paulo: Cia. das Letras, 2010.

KANDELL, S. "Stagebridge: The Magic of Theater with Real Older Actors Journal." Generations. 2006; vol. 30.

KELEMAN, Stanley. Anatomia emocional. São Paulo: Summus, 1992.

HERMÓGENES, J. Saúde na Terceira Idade. Rio de Janeiro: Nova Era, 1996.

KERVIO, G.; CARRE F.; VILLEN, S. "Reliability and Intensity of the Six-Minute Walk Test in Healthy Elderly Subjects." Medicine and Sciense in sports and exercise. 2003, 35: 169-174.

KRISTENSEN, C. H.; ALMEIDA, R. M. M.; GOMES, W. B. "Desenvolvimento histórico e fundamentos metodológicos da neuropsicologia cognitiva. Psicologia, Reflexão e Crítica. 2001, $14(2)-$ pp. 259-274.

LABAN, R. Dança educativa moderna. São Paulo: Ícone, 1990.

LABAN, R. Domínio do movimento. Ed. Org. por Lisa Ullman. São Paulo: Summus, 1978.

LAMBERTUCCI, R. H.; PITHON-CURY, T. C. “Alterações do sistema neuromuscular com o envelhecimento e a atividade física." Saúde em Revista. Piracicaba, 7 (17): 53-56, 2005. 
LENT, R. Cem bilhões de neurônios? Conceitos fundamentais de Neurociencias. $2^{\underline{a}}$ ed. Rio de Janeiro: Atheneu, 2010.

LIKERT, R. "A tecnique for the measurement of attitudes." Archives of Psycology 1932; 140: pp. 1-55.

LIMA, M.P. “Gerontologia educacional”. Revista Kairós, São Paulo, v,4, p.109-121, 2001.

LOURES, M. C.; PORTO, C. C.; BARBOSA, M. A.; FREIRE-FILHA, L. G. "Women's quality of the life: University of the Third Age, Goiás, Brazil.” Rev. Saúde Pública 2010; 12(3): 391-401.

LOWEN, Alexander. Bioenergética. 4ª ed. São Paulo: Summus, 1982.

LUNDY-EKMAN, Laurie. Neurociência: fundamentos para reabilitação. Rio de Janeiro: Elsevier, 2004;

COLCOMBE, S. J; KRAMER, A. F.; McAUlEY, E.; ERICKSON, K. I.; SCALF, P.

"Neurocognitive aging and cardiovascular fitness: recent findings and future directions." J. Mol. Neurosc. 2004; 24 (1): 9-14.

MacKRONE, John. Como o cérebro funciona. São Paulo: Publifolha, 2007.

MARTIN, J. H. Neuroanatomia : texto e atlas. $2^{\underline{a}}$ ed. Porto Alegre: Artmed, 1998.

MATHIAS, S.; NAYAK, U. S. L.; ISAACS, B. "Balance in the elderly patient: The 'Get-up and Go' Test.” Arch. Phys. Med. Rehabil. 1986; 667;387.

MATOS, C.; SILVA, D. M. "Núcleo de Artes Cênicas da Estação Ciência - Popularizar a Ciência por meio da Arte." IN: MATOS, C. (org.).Ciência e Arte - Imaginário e Descoberta. São Paulo: Editora Terceira Margem, 2003. pp. 255-2. 
MATOS, C. "Experiências da inter-relação Ciência e Arte e a educação na Estação CiênciaUSP." IN: MATOS, C. (org.). Conhecimento científico e vida cotidiana. São Paulo: Editora Terceira Margem, 2003; pp. 209-218.

MEIRELES, A. L.; PEREIRA, L. M. S.; OliVEIRA, T. G.; CHRISTOFOLETTI, G.; FONSECA, A. L. “Alterações neurológicas fisiológicas do envelhecimento afetam o sistema mantenedor do equilíbrio.” Rev. Neurociências. São Paulo, 18 (1), 103-108, 2010.

MENDES, A.K., CARDOSO, F.L., SACOMORI. "Neurônios-espelho". Neurociências. Vol.4. $n^{\circ}$ 2. Marc/abril, 2008.

MERLEAU-PONTY, M. A estrutura do comportamento. Belo Horizonte: Editora Interlivros, 1975.

Fenomenologia da percepção. São Paulo: Martins Fontes, 2006.

MIERRE, J. “Lights, camera, action.” Nursing Older People, junho, vol. 16 (4), 2004.

MINAYO, M. C. S. "Metodologia qualitativa e método clínico-qualitativo: um panorama geral de seus conceitos e fundamentos". Disponível no site http://www.sepq.org.br/IIsipeq/anais/pdf/poster1/05.pdf. Consulta em 2011.

MINISTÉRIO DA SAÚDE. Envelhecimento e saúde da pessoa idosa. Brasília. $1^{\underline{a}}$ edição, 2007.

MIYAMOTO, S. T.; LOMBARDI, J. R. I.; BERG, K. O.; RAMOS, L. R.; NATOUR, J. "Brazilian version of the Berg balance scale." Brazilian Journal of Medical and Biological Research. 2004, 37: 1411-1421.

MOLARIUS, A, SEIDELL, J. C.; SANS, S.; TUOMILEHTO, J.; KUULASMAA, K. "Varying sensitivity of waist action levels to identify subjects with overweight or obesity in 19 populations of the WHO MONICA Projetct.” J. Clin. Epidemiol, 1999; 52:1213-24. 
MOORE, K. L; AGUR, A. M. R. Fundamentos de Anatomia Clínica. 2ª ed. Rio de Janeiro: Guanabara Koogan, 2004;.

MORENO, A. B.; FAERSTEIN, E.; WERNECK, G. L.; CHOR, D. "Propriedades psicométricas do instrumento abreviado de avaliação de qualidade de vida da Organização Mundial da Saúde no Estudo Pró-Saúde.” CAD. Saúde Pública, Rio de Janeiro, 22(12): 25852597, dez, 2006.

NERI, A.L. "O legado de Paul B. Baltes à psicologia do desenvolvimento e do envelhecimento." Temas em Psicologia, 2006, vol. 14, no 1, 17-34.

NERI, A.L. "Envelhecimento e Qualidade de Vida na mulher". In: Anais... $2^{\circ}$ Congresso Paulista de Geriatria e Gerontologia. Universidade Estadual de Campinas, 2001a.

NETTER, Frank H. - Atlas de Anatomia Humana. São Paulo: Editora Elsevier, 2008.

NEVES, Neide. Klauss Vianna - estudos para uma dramaturgia corporal. São Paulo: Cortez Editora, 2008.

NICOLELIS, Miguel. Muito além do nosso eu: a nova neurociência que une cérebro e máquinas - e como ela pode mudar nossas vidas. São Paulo: Cia. das Letras, 2011.

NOICE, H.; NOICE, T. "An Arts Intervention for Older Adults Living in Subsidized Retirement Homes". NIH Public Access. 2009: 16(1); 56-79.

NOONAN, V.; DEAN, E. "Submaximal Exercise Testing Clinical Application and Interpretation.” Physical Therapy, 2000; 80:782-807.

NOVELLY, Maria C. Jogos teatrais: exercícios para grupos e sala de aula. $2^{\underline{a}}$ ed. Campinas/São Paulo: Papirus, 1996.

OLIVA, A. D; OTTA, E.; BUSSAB, V. S. R. et al. "Razão, emoção e ação em cena: a mente humana sob um olhar evolucionista". Psicologia Teorias e Pesquisa. Brasília, Jan-Abr. 2006. Vol. 22, nº 1, pp. 53-62. 
OKIMURA, Tiemi. "Processo de aprendizagem de idosos sobre os benefícios da atividade física.” 2005. 128f. Tese (Mestrado em Educação Física) - Escola de Educação Física e Esporte, Universidade de São Paulo, São Paulo, 2005.

PAVIS, P. Dicionário de teatro. $3^{\underline{a}}$ ed. São Paulo: Perspectiva, 2008;

PEREIRA, Sayonara. Rastro do Tanztheater no processo criativo de ES-BOÇO: espetáculo cênico com alunos do Instituto de Artes da UNICAMP. São Paulo: Annablume Editora, 2010;

PHELAN, E. A; ANDERSON, L. A.; LACROIX, A. Z. \& LARSON, E. B. Olders adults' views of 'successful aging'. How do they compare with researchers' definitions?" Journal of American Geriatrics Society, 2004, 52 (2), 211-216.

PIRJO, K. "Body movements during postural stabilization - measurements with a motion analysis system.” Oulu: Oulu University Press, 2002.

PODSIADLO, D., RICHARDSON, S. “The timed 'Up \& Go': a test of basic functional mobility for frail elderly persons. J. Am. Geriatr. Soc. 1991.

POWER et al. "Development of the WHOQOL-OLD module." Quality of life Research. V. $14, \mathrm{n}^{\mathrm{o}} 10, \mathrm{p} .2197-2214,2005$.

PYMAN, T.; RUGG, S. "Participating in a community theatre production: A dramatherapeutic perspective." International Journal of Therapy and Rehabilitation - IJTR: 2006; 13(12); 562-571.

RAMACHANDRA, V. S.; HIRSTEIN, W. "The Science of Art: A Neurological theory of Aesthetic Experience.” Journal of Consciousness Studies, v. 6, no 6-7, 1999.

REICH, Wilhelm. A função do orgasmo. 9ª ed. São Paulo: Ed. Brasiliense, 1975.

REJESKI W. J.; FOLEY, K. O.; WOODARD, C. M.; ZACCARO, D. J.; BERRY, M. J. "Evaluating and Understanding Performance Testing in Corp Patients." J. Cardiopulmonary Rehabil. 2000, 20: 79-88. 
RIBEIRO, M. M.; TEIXEIRA, A. L. "Ensaiando dentro da mente: dança e neurociência.” IN: Repertório: teatro \& dança / Universidade Federal da Bahia. Escola de Teatro. Escola de Dança. Programa de Pós-Graduação em Artes Cênicas. - Ano 12, nº 12 (2009) - Salvador: UFBA/ PPGAC, 2009.

RIZZOLATTI, G.; CRAIGHERO, L. "The Mirror neuron system and its function in humans." Anat. Embryol. 2005; 210: 419-21.

ROGERS, M.E., ROGERS, N.L., TAKESHIMA, N., ISLAM, M.M. "Methods to assess and improve the physical parameters associated with fall risk in older adults". Prev Med. 2003;36(3):255-64.

SAGAN, Carl. Os dragões do Éden. 5ª ed. Rio de Janeiro: F. Alves, 1987.

SANTOS, F. H.; ANDRADE, V. M.; BUENO, O. F. A. "Envelhecimento: um processo multifatorial.” Psicologia em estudo, Maringá, v. 14, no 1, pp. 3-10, jan./mar. 2009.

SCHENBERG, Mário. Pensando a arte. São Paulo: Nova Stella, 1988.

SHEPHARD, R. J. Envelhecimento, atividade física e saúde. São Paulo: Editora Phorte, 2003.

SIlVA, A.; ALMEIDA, G. J. M.; CASSILHAS, R.; COHEN, M. et al. "Equilíbrio, coordenação e agilidade de idosos submetidos á prática de exercícios físicos resistidos.” Rev. Bras. Med. Esporte, Vol.14, nํㅡㄹ mar/abr 2008.

SILVA, H. S.; LIMA, A. M. M.; GALHARDONI, R. "Envelhecimento bem-sucedido e vulnerabilidade em saúde: aproximações e perspectivas." Interface Comunicação Saúde Educação, v.14, no 35 , pp. 867-77, out/dez, 2010.

SKEVINGTON, SM, LOTFY, M, O'CONNELL, K. A. "The World Health Organization's WHOQOL-Bref quality of life assessment: psychometric properties and results of the internacional field trial - A Report from the Whoqol Group." Quality of Life Research 13: 299-310, 2004. 
SMITH, R. "Timed Up and Go... and Beyond.” Disponível em www.saskbalance.com, 2009. Consulta em 2011.

SOARES, K. V.; FIGUEIREDO, K. M. O. B.; CALDAS, V. V. A.; GUERRA, R. O. “Avaliação quanto à utilização e confiabilidade de instrumentos de medida do equilíbrio corporal em idosos.” PubllCa I. 2005; 78-85.

SOCIEDADE BRASILEIRA DE ENDOCRINOLOGIA E METABOLOGIA - SBEM. Sobrepeso e obesidade: diagnóstico. Projeto Diretrizes - Assoc. Méd. Brás. E Cons. Fed. de Med. Disponível em www.projetodiretrizes.org.br, 2004.

SOCIEDADE BARSILEIRA DE CARDIOLOGIA - SBC. V Diretrizes Brasileiras de Hipertensão Arterial. Disponível em www.scielo.br, 2006. Consulta ao site em 1012.

SOCIEDADE BBRASILEIRA DE CARDIOLOGIA - SBC. "II Guidelines on Ergometric Tests of the Brazilian Society of Cardiology.” Arq. Bras. Cardiol. 2002; 78 (Supl 2): 1-17.

SOLSO, R. L.The cognitive neuroscience of art.” Journal of Consciousness Studies, 2000.

SOLWAY, S.; BROOKS, D.; LACASSE, Y.; THOMAS, S. "A qualitative systematic overview of the measurement properties of functional walk tests used in the cardiorespiratory domain. Chest.” 2001, 119: 256-270.

SOUZA, G.S., GONÇALVES, D.F., PASTRE, C.M. "Propriocepção cervical e equilíbrio: uma revisão". Fisioterapia em Movimento, Curitiba, v.19, n.4, p.33-40, out./Dez., 2006.

SOUZA, R., FRAGA, J.S., GOTTSCHALL, C.B.A., BUSNELlO, F.M., RABITO, E.I. "Avaliação antropométrica em idosos: estimativas de peso e altura e concordância entre classificação de IMC". Revista brasileira de geriatria e gerontologia. vol.16 no.1 Rio de Janeiro Jan./Mar. 2013.

SPOLIN, V. O jogo teatral no livro do diretor. $2^{2}$ ed. São Paulo: Perspectiva, 2008. 
SPOLIN, V. Improvisação para o teatro. $5^{\text {a }}$ ed. São Paulo: Perspectiva, 2010.

STEELE, R. N. B. "Timed Walking Tests of Exercise Capacity in Chonic Cadiopulmonary Illness.” J. Cardiopulmonary Rehabil. 1996; 16: 25-33.

SZONDI, P. Teoria do drama moderno (1800-1950). São Paulo: Cosac \& Naif, 2000.

TEIXEIRA, J. F. Mente, cérebro e cognição. Petrópolis: Vozes, 2000.

TEIXEIRA, INDO; NERI, A. L. "Envelhecimento bem-sucedido: uma meta no curso da vida.” Psicologia USP, São Paulo, jan/mar. 2008, 19 (1), 81-94.

THE WHOQOL GROUP. WHOQOL-bref: introduction, administration, scoring and generic version of assessment. Geneva: World Health Organization, 1996.

TODOROV, J.C., MOREIRA, M.B. “O conceito de motivação na psicologia”, Rev. Bras. Ter. Comport. Cogn. Vol.7: nº1. São Paulo, Jun. 2005.

TRENTINI, C. M.; XAVIER, F. M. F.; FLECK, M. P. A. “Qualidade de vida em idosos.” IN: PARENTE, M. A. M. P. (Org.) Cognição e envelhecimento. Porto Alegre: Artmed, 2009.

TROOSTER, T.; GOSSELINK, R.; DECRAMER, M. "Six minute walking distance in healthy eldely subjects.” Eur. Respir. J. 1999; 14 (2): 270-4.

VALENTIJN, S. A. M.; VAN HOOREN, S. A. H.; BOSMA, H.; TOUW, D. M.; JOLLES, J.; VAN BOXTEL, M. P.; PONDS, R. W. et al. "The effect of two types of memory training on subjective and objective memory performance in healthy individuals aged 55 years and older: a randomized controlled trial." Patiente Educ. Couns. 2005; 57(1): 106-14.

VELASCO, G. C. Aprendendo a envelhecer à luz da psicomotricidade. São Paulo: Editora All Print, 2005. 
VELLAS, B. J.; WAYNE, S. J.; ROMERO, L.; BAUMGARTNER, R. N.; RUBENSTEIN, L. Z.; GARRY, P. J. "One-leg balance is an important predictor of injurious falls in older persons.” J. Am. Geriatr. Soc. 1997.

VIANNA, Klauss. A dança. $3^{\mathrm{a}}$ ed. São Paulo: Summus, 2005.

VIGOTSKY, L. S. Pensamento e linguagem. São Paulo: Martins Fontes, 1987.

WEKWERTH, M. Diálogos sobre a encenação - um manual de direção teatral. São Paulo: Hucitec, 1997.

WELTON P. K.; HE, J.; APPEL, L. J.; CUTLER, J. A.; HAVAS, S.; KOTCHEN, T. A.; ROCCELlA, E. J.; STOUT, R.; VALBONA, C.; WINSTON, M. C.; KARIMBAKAS, J.; "Primary prevention of hypertension: clinical and public health advisory from the National High Blood Pressure Education Program.” Jama 2002: 288: 1882-8.

WHOQOL. "The World Health Organization quality of life assessment (WHOQOL): position paper from WHO.” Social Science and Medicine, 1995, 41 (10): 1403-1410.

WHOQOL Group. "Development of the World Health Organization WHOQOL-Bref Quality of Life assessment.” Psychological Medicine. V. 28, p.551-558, 1998b;

WORKMAN, L. \& READER, W. Evolutionary Psychology: An Introduction. Cambridge: Cambridge University Press, 2004.

YUSUF, S.; HAWKEN, S.; OUNPUU, S.; DANS, T.; AVEZUM, A.; LANAS, F.; MCQUEEN, M.; BUDAJ, A.; PAIS, P.; VARIGOSJ.; LISHENG, L.; "Effect potentially modifiable risk factors associated with myocardial infarctionin 52 countries (the INTERHEART study): case-control study”. Lancet 2004: 364-937-52.

ZABLOTNYC. "Elders share the arts: transforming memory into art." Generations. 2006; V. 30, 57-58; consulta ao site em 2011. 
ZAR, Jerrold. Biostatistical Analysis. 5a ed. Rio de Janeiro: Editora Prentice-Hall do Brasil, 2009.

ZEKI, Semir. “Artistic creativity and the brain.” Science 6 - julho 2001: vol. 293 nº 5527 pp. $51-52$. 
APÊNDICE 
APÊNDICE I - Carta de Aprovação - Projeto de Pesquisa

Erro! Indicador não definido.
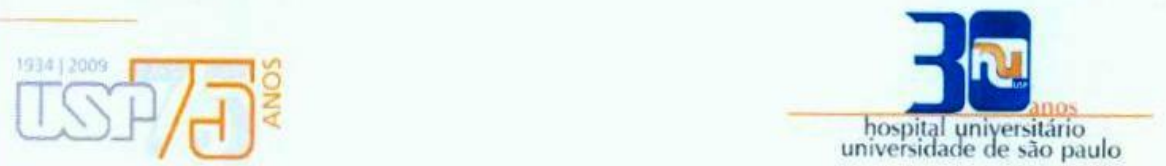

São Paulo, 20 de junho de 2011

Il ${ }^{\text {mo(a) }}, S^{\text {r(a) }}$.

Adenilson Matos do Nascimento

Programa de Pós-Graduação Neurociências e Comportamento

Instituto de Psicologia

UNIVERSIDADE DE SÃO PAULO

REFERENTE: Projeto de Pesquisa "Estudo da influência das artes cênicas no comportamento de uma população com idade acima de 60 anos" - Pesquisador responsável: Adenilson Matos do Nascimento - Orientadora: Profa. Dra. Maria Inês Nogueira - Registro CEP-HU/USP: 1084/11 - SISNEP CAAE: 0002.0.134.198-11.

Prezado(a) Senhor(a)

O Comitê de Ética em Pesquisa do Hospital Universitário da Universidade de São Paulo, em reunião ordinária realizada no dia 17 de junho de 2011, analisou o Projeto de Pesquisa acima citado, considerando-o como APROVADO, bem como o seu Termo de Consentimento Livre e Esclarecido.

Lembramos que cabe ao pesquisador elaborar e apresentar a este Comitê, relatórios anuais (parciais ou final, em função da duração da pesquisa), de acordo com a Resolução n 196/96 do Conselho Nacional de Saúde, inciso IX.2, letra "c".

O primeiro relatório está previsto para 17 de junho de 2012.

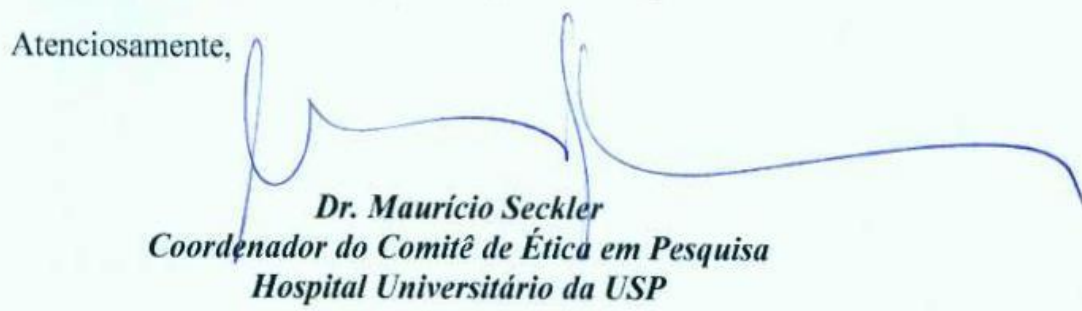

COMITÊ DE ÉTICA EM PESQUISA DO HOSPITAL INIVERSTTÁRIO DA ISP Avenida Professor Lineu Prestes, 2565 - Cidade I niversitária - 05508-000 Såo Paulo - SP

Tels.: (11) 3091-9457 - Fax: (11) 3091-9479 - E-mail: cepa hu.usp.br 


\section{APÊNDICE II \\ TERMO DE CONSENTIMENTO LIVRE E ESCLARECIDO (TCLE)}

(Convite ao voluntário)

O projeto "Só com Experiência - Estudo da influência da prática com as artes cênicas e atividade autobiográfica e literária no comportamento de uma população com idade acima de 60 anos" tem como objetivo compreender e avaliar a influência do exercício teatral, estudo e desenvolvimento de espetáculo cênico, em uma população com idade acima de 60 anos pela análise de parâmetros fisiológicos, bioquímicos e suas eventuais consequências na forma (posturas) e expressões comportamentais. Seu desenvolvimento se justifica por haver poucos estudos sobre Neurociência, Teatro e terceira idade, e na medida em que, com os dados obtidos dessa pesquisa, se pretende contribuir para melhor compreensão desta fase da vida, bem como subsidiar a elaboração de ações sociais, terapêuticas e preventivas no sentido de propiciar, preservar e ampliar a qualidade de vida do ser humano.

A realização da pesquisa terá como foco 30 pessoas integrantes do projeto Só com Experiência - pesquisa cênica para pessoas acima de 60 anos de idade, do Núcleo de Artes Cênicas da Estação Ciência - USP, dividido em dois subgrupos, sendo o primeiro com 15 pessoas pertencentes ao Grupo Experimental (GE) e o segundo, também com 15 pessoas, pertencentes ao Grupo Controle $(G C)$. O período da pesquisa será seis meses e suas atividades ocorrerão sobre práticas corporais das técnicas do Movimento Consciente, de Klauss Vianna, e Contato Improvisação, de Steve Paxton, jogos cênicos, exercícios de voz, leituras e interpretação de obras teatrais, narrativas pessoais, montagem e realização de espetáculo cênico. Utilizaremos como recursos de verificação os seguintes procedimentos no início e fim da pesquisa:

- Questionário Informações Sociodemográficas, com 33 perguntas;

- Realização de avaliação física (Six-Minute Walk Test, TimedUpand GO Test e One-Leg Balance Test) e clínica (dosagem do colesterol total, HDL-colesterol, triglicérides e a glicemia de jejum, bem como de antropometria);

- Aplicação dos questionários WHOQOL-bref e WHOQOL-OLD;

- Aplicação do Mini Exame do Estado Mental - MEEM e CAMCOG;

- registro do processo de trabalho e depoimentos em vídeo;

- entrevistas individuais e em grupo;

- apresentação do resultado cênico para o público em geral;

- avaliação/relatório do projeto por meio da análise dos procedimentos desenvolvidos, que serão objeto de estudos e publicações.

No decorrer do processo da pesquisa pode haver alguns desconfortos e também riscos. Como o trabalho está centrado na exposição cênica do próprio corpo da pessoa em observação, poderemos ter, em certos momentos, sentimentos de constrangimento, timidez, incapacidade de 
realização de tarefas oferecidas, e graus de possibilidade de quedas e encontros (trombadas). No início do trabalho, esses desconfortos e riscos podem ter uma probabilidade maior, porém, com a prática a tendência é diminuir e até mesmo desaparecer, pois essas situações serão trabalhadas continuamente pelo diálogo e práticas cênicas. Desta forma, os benefícios decorrentes da pesquisa são justamente a superação dessas condições e promoção de autoestima, valorização da história pessoal, além de favorecer o prazer do convívio em grupo e a oportunidade de praticar e compreender o fazer teatral.

É importante esclarecer que, caso o voluntário decida não participar, existem outros tipos de atividade que contribuem para o conhecimento do corpo, desenvolvimento pessoal e melhor qualidade de vida tal qual como nos propomos a fazer por meio do teatro, a saber: canto coral, práticas corporais como loga, Aikidô, Tai Chi Chuan, viagens em grupo, escrever livros, entre outros.

Por outro lado, vale salientar que durante todo o período da pesquisa o voluntário tem o direito de tirar qualquer dúvida ou pedir qualquer outro esclarecimento, bastando para isso entrar em contato com algum dos pesquisadores ou com o Conselho de Ética em Pesquisa. Assim como a liberdade de retirar o consentimento a qualquer momento e, portanto, deixar de participar do estudo, sem nenhum tipo de prejuízo ou retaliação pela sua decisão.

As informações e imagens desta pesquisa serão confidencias, e serão divulgadas apenas em eventos ou publicações científicas, não havendo identificação dos voluntários por meio dos nomes em legenda ou áudio, a não ser entre os responsáveis pelo estudo, sendo assegurado o sigilo sobre sua participação.

Os gastos necessários para a participação na pesquisa, como transporte e alimentação, serão assumidos pelo próprio voluntário. No entanto, fica garantida a disponibilidade de assistência, por eventuais danos à saúde, comprovadamente decorrentes da participação na pesquisa, conforme decisão judicial ou extrajudicial. Em caso de necessidade, o participante será encaminhando para atendimento no Hospital Universitário da USP, na rede pública de saúde ou a seu critério, por convênio médico por ele mantido.

Para o caso de intercorrências clínicas e reações adversas ou mesmo para esclarecimento de dúvidas seguem dados de identificação e contato do pesquisador envolvido:

Nome: Adenilson Matos do Nascimento. Endereço residencial: Rua São Benedito, 2367 Apto. 23a - Santo Amaro - SP Endereço de realização da pesquisa: Rua Guaicurus, 1394 - Lapa São Paulo - SP......Telefones para contato: 11 3871-6759 (Estação Ciência), 11 7421-6246 (celular) e 11 4305-1065 (casa).

Nome: Maria Inês Nogueira. Endereço residencial: Rua Mario Maglio, 168 - Jardim Previdência - São Paulo -SP..... Endereço de trabalho: Av. Prof. Lineu Prestes, 2415. São Paulo, Brasil Telefones : 11 3091-7401 (Laboratório de Neurociências e Comportamento ICB-USP) 11 9821-5109 
Dados do voluntário:

Nome:

№ do documento de identidade:..........Sexo:

Data de nascimento:

Endereço: Telefone.

Diante do exposto, declaro que, após convenientemente esclarecido pelo pesquisador e ter entendido o que me foi explicado, consinto em participar do presente Projeto de Pesquisa e que meus dados e imagens produzidos sejam utilizados apenas para fins científico e educacional.

São Paulo, de julho de 2011

Assinatura do voluntário ou responsável....... Assinatura pesquisador legal responsável - USP

Comitê de Ética em Pesquisa do Hospital Universitário. Endereço: Av. Prof. Lineu Prestes, 2565 Cidade Universitária - CEP: 05508-000 - São Paulo - SP - Telefone: 3091-9457 -.Fax: 3091-9452 .E-mail: cep@hu.usp.br. 


\section{APÊNDICE III}

Questionário Informações Sociodemográficos

№

\section{Nome:}

\section{Sexo:}

1. ( ) Feminino

2. () Masculino

3. Data de nascimento:

4. Idade:

5. Local de nascimento:

6. Estado civil atual:

1. ( ) Solteiro/solteira (nunca casou)

2. ( ) Casado/casada ou com companheiro/companheira

3. ( ) Separado/Separada/Divorciado/Divorciada (sem companheiro/companheira atual)

4. ( ) Viúvo/viúva

5. ( ) Outro. Qual?

\section{Mais alto nível de escolaridade alcançado:}

1. ( ) Nenhuma

2. ( ) Ensino Fundamental incompleto

3. ( ) Ensino Fundamental completo

4. ( ) Ensino Médio incompleto

5. ( ) Ensino Médio completo

6. ( ) Curso técnico incompleto

7. ( ) Curso técnico completo

8. ( ) Curso superior incompleto

9. ( ) Curso superior completo

10. ( ) Pós-Graduação

11. ( ) Outro. Qual?

\section{Quantos anos de escolaridade?}

\section{Qual a sua renda?}

1. ( ) De 1 a 2 salários mínimos

2. ( ) De 3 a 4 salários mínimos

3. ( ) De 5 a 6 salários mínimos

4. ( ) De 7 a 8 salários mínimos 
5. ( ) De 9 a 10 salários mínimos

6. ( ) Mais de 10 salários mínimos

10. Mora com alguém:

1. ( ) Esposo(a)

2. ( ) Filho(a)

3. ( ) Parente

4. ( ) Amigo(a)

5. ( ) Instituição

6. ( ) Sozinho

7. ( ) Pais

8. ( ) Outro:

11. Sua residência é:

1. ( ) Própria

2. ( ) Alugada

3. ( ) Instituição

4. ( ) De familiar

12. Qual era a sua profissão anterior?

13. Qual a sua ocupação atual:

1. ( ) Aposentado/ Aposentada

2. ( ) Pensionista

3. ( ) Nunca trabalhou

4. ( ) Dona de casa

5. ( ) Outro:

\section{Realiza atividades de lazer?}

1. ( ) Não

2. ( ) Sim

Qual?

1. ( ) Leitura

2. ( ) Música

3. ( ) Palavras cruzadas

4. ( ) Bingo

5. ( ) Televisão

6. ( ) Futebol

7. ( ) Jogo de bocha,

8. ( ) Cartas

9. ( ) Damas

10. ( ) Cinema

11. ( ) Atividades manuais 
12. ( ) Viagens

13. ( ) Caminhada

14. ( ) Baile

15. ( ) Atividades na igreja

16 . ( ) Computador

17. ( ) Outro:

15. Se fez teatro, com quem, onde e qual espetáculo montado?

16. Onde vive, tem acesso a:

1. ( ) Telefone

2. ( ) Rádio

3. ( ) TV

4. ( ) Jornais / revista / livros

5. ( ) Computador

6. ( ) Nenhum

17. De um modo geral, você se considera uma pessoa saudável ou doente:

1. ( ) Saudável

2. ( ) Doente

18. Tem algum problema de saúde?

1. ( ) Sim. Qual?

2. ( ) Não

19. Atualmente, usa alguma medicação/remédio?

1. ( ) Sim

2. ( ) Não

Qual (is)? E para que serve(m)?

1.

2.

3.

20. Quantas horas você dorme por noite?

21. Você dorme durante o dia?

1. ( ) Não

4. ( ) Sim. Quantas horas?

22. Você realiza algum tipo de atividade física?

1. ( ) Sim. Qual?

2. ( ) Não 
23. Você acha que tem alguma limitação?

1. ( ) Não

4. ( ) Sim. Qual?

24. Você sente alguma dor?

1. ( ) Não

4. ( ) Sim. Onde?

25. 0 que acha da sua memória?

( ) É ótima ( ) É boa ( ) É regular ( ) É ruim

26. Acha que sua memória mudou com a idade?

( ) $\operatorname{Sim}$ ( ) Não

Como?

27. $O$ que acha de sua atenção?

( ) É ótima ( ) É boa ( ) É regular ( ) É ruim

28. Acha que sua atenção mudou com a idade?

( ) $\operatorname{Sim}$ ( ) Não

Como?

29. 0 que acha da sua mobilidade física?

( ) É ótima ( ) É boa ( ) É regular ( ) É ruim

30. Acha que sua mobilidade mudou com a idade?

( ) $\operatorname{Sim}$ ( ) Não

Como?

31. Por que você quer participar dessa atividade cênica (teatro, dança e circo)?

32. Qual a sua expectativa em relação ao curso/projeto?

33. Qual a sua opinião sobre a arte?

Obrigado! 


\section{APÊNDICE IV}

Estudo da influência da prática com as artes cênicas e atividade autobiográfica e literária no comportamento de uma população com mais de 60 anos de idade.

\section{DEPOIMENTO 1}

O QUE FAÇO ATUALMENTE E POR QUE RESOLVI FAZER TEATRO. 
APÊNDICE V

Estudo da influência da prática com as artes cênicas e atividade autobiográfica e literária no comportamento de uma população com mais de 60 anos de idade.

DEPOIMENTO 2 - Narrativa

UM FATO MARCANTE NA MINHA VIDA. 


\title{
WHOQOL - ABREVIADO
}

\author{
Versão em Português
}

\section{Instruções}

Este questionário é sobre como você se sente a respeito de sua qualidade de vida, saúde e outras áreas de sua vida. Por favor, responda a todas as questões. Se você não tem certeza sobre que resposta dar em uma questão, por favor, escolha entre as alternativas a que lhe parece mais apropriada. Esta, muitas vezes, poderá ser sua primeira escolha.

Por favor, tenha em mente seus valores, aspirações, prazeres e preocupações. Nós estamos perguntando o que você acha de sua vida, tomando como referência as duas últimas semanas. Por exemplo, pensando nas últimas duas semanas, uma questão poderia ser:

\begin{tabular}{|l|c|c|c|c|c||}
\hline & nada & $\begin{array}{c}\text { muito } \\
\text { pouco }\end{array}$ & médio & muito & completamente \\
\hline $\begin{array}{l}\text { Você recebe dos outros o apoio de que } \\
\text { necessita? }\end{array}$ & 1 & 2 & 3 & 4 & 5 \\
\hline
\end{tabular}

Você deve circular o número que melhor corresponde ao quanto você recebe dos outros o apoio de que necessita nestas últimas duas semanas. Portanto, você deve circular o número 4 se você recebeu "muito" apoio como abaixo.

\begin{tabular}{|l|c|c|c|c|c||}
\hline & nada & $\begin{array}{c}\text { muito } \\
\text { pouco }\end{array}$ & médio & muito & completamente \\
\hline $\begin{array}{l}\text { Você recebe dos outros o apoio de que } \\
\text { necessita? }\end{array}$ & 1 & 2 & 3 & 4 & 5 \\
\hline
\end{tabular}

Você deve circular o número 1 se você não recebeu "nada" de apoio. 
Por favor, leia cada questão, veja o que você acha e circule no número e the parece a melhor resposta.

\begin{tabular}{||l|l|c|c|c|c|c|}
\hline \hline $1(\mathrm{G} 1)$ & $\begin{array}{c}\text { muito } \\
\text { ruim }\end{array}$ & $\begin{array}{l}\text { Ruim } \\
\text { vida? }\end{array}$ & $\begin{array}{c}\text { nem ruim } \\
\text { nem boa }\end{array}$ & boa & $\begin{array}{c}\text { muito } \\
\text { boa }\end{array}$ \\
\hline
\end{tabular}

\begin{tabular}{||l|l|c|c|c|c|c||}
\hline \hline & $\begin{array}{c}\text { muito } \\
\text { insatisfeito }\end{array}$ & Insatisfeito & $\begin{array}{c}\text { nem satisfeito } \\
\text { nem insatisfeito }\end{array}$ & satisfeito & $\begin{array}{c}\text { muito } \\
\text { satisfeito }\end{array}$ \\
\hline 2 (G4) & $\begin{array}{l}\text { Quão satisfeito(a) você está } \\
\text { com a sua saúde? }\end{array}$ & 1 & 2 & 3 & 4 & 5 \\
\hline
\end{tabular}

As questões seguintes são sobre o quanto você tem sentido algumas coisas nas últimas duas semanas.

\begin{tabular}{||l|l|c|c|c|c|c|}
\hline \hline & & nada & $\begin{array}{c}\text { muito } \\
\text { pouco }\end{array}$ & $\begin{array}{c}\text { mais ou } \\
\text { menos }\end{array}$ & bastante & extremamente \\
\hline 3 (F1.4) & $\begin{array}{l}\text { Em que medida você acha que sua dor } \\
\text { (física) impede você de fazer o que } \\
\text { você precisa? }\end{array}$ & 1 & 2 & 3 & 4 & 5 \\
\hline 4 (F11.3) & $\begin{array}{l}\text { O quanto você precisa de algum } \\
\text { tratamento médico para levar sua vida } \\
\text { diária? }\end{array}$ & 1 & 2 & 3 & 4 & 5 \\
\hline 5 (F4.1) & O quanto você aproveita a vida? & 1 & 2 & 3 & 4 & 5 \\
\hline 6 (F24.2) & $\begin{array}{l}\text { Em que medida você acha que a sua } \\
\text { vida tem sentido? }\end{array}$ & 1 & 2 & 3 & 4 & 5 \\
\hline 7 (F5.3) & O quanto você consegue se concentrar? & 1 & 2 & 3 & 4 & 5 \\
\hline 8 (F16.1) & $\begin{array}{l}\text { Quão seguro(a) você se sente em sua } \\
\text { vida diária? }\end{array}$ & 1 & 2 & 3 & 4 & 5 \\
\hline 9(F22.1) & $\begin{array}{l}\text { Quão saudável é o seu ambiente físico } \\
\text { (clima, barulho, poluição, atrativos)? }\end{array}$ & 1 & 2 & 3 & 4 & 5 \\
\hline
\end{tabular}

As questões seguintes perguntam sobre Quão completamente você tem sentido ou J capaz de fazer certas coisas nestas últimas duas semanas.

\begin{tabular}{||l|l|c|c|c|c|c||}
\hline \hline $10(\mathrm{~F} 2.1)$ & nada & $\begin{array}{l}\text { muito } \\
\text { pouco }\end{array}$ & médio & muito & completamente \\
\hline $11(\mathrm{~F} 7.1)$ & Você tem energia suficiente para seu dia-a- & 1 & 2 & 3 & 4 & 5 \\
\hline 12 (F18.1) & $\begin{array}{l}\text { Você tem dinheiro suficiente para satisfazer } \\
\text { suas necessidades? }\end{array}$ & 1 & 2 & 3 & 4 & 5 \\
\hline 13 (F20.1) & $\begin{array}{l}\text { Quão disponíveis para você estão as } \\
\text { informações que precisa no seu dia-a-dia? }\end{array}$ & 1 & 2 & 3 & 4 & 5 \\
\hline $14(\mathrm{~F} 21.1)$ & $\begin{array}{l}\text { Em que medida você tem oportunidades de } \\
\text { atividade de lazer? }\end{array}$ & 1 & 2 & 3 & 4 & 5 \\
\hline
\end{tabular}


As questões seguintes perguntam sobre Quão bem ou satisfeito você se sentiu a respeito de v<rios aspectos de sua ida nas últimas duas semanas.

\begin{tabular}{||l|l|c|c|c|c|c|}
\hline \hline & & $\begin{array}{c}\text { muito } \\
\text { ruim }\end{array}$ & ruim & nem ruim & bom & $\begin{array}{c}\text { muito } \\
\text { bom }\end{array}$ \\
\hline $15(\mathrm{~F} 9.1)$ & Quão bem você é capaz de se locomover? & 1 & 2 & 3 & 4 & 5 \\
\hline
\end{tabular}

\begin{tabular}{|c|c|c|c|c|c|c|}
\hline & & $\begin{array}{c}\text { muito } \\
\text { insatisfeito }\end{array}$ & Insatisfeito & $\begin{array}{c}\text { nem satisfeito } \\
\text { nem insatisfeito }\end{array}$ & satisfeito & $\begin{array}{c}\text { muito } \\
\text { satisfeito }\end{array}$ \\
\hline $16(\mathrm{~F} 3.3)$ & $\begin{array}{l}\text { Quão satisfeito(a) você está com o } \\
\text { seu sono? }\end{array}$ & 1 & 2 & 3 & 4 & 5 \\
\hline 17(F10.3) & $\begin{array}{l}\text { Quão satisfeito(a) você está com sua } \\
\text { capacidade de desempenhar as } \\
\text { atividades do seu dia-a-dia? }\end{array}$ & 1 & 2 & 3 & 4 & 5 \\
\hline $18(\mathrm{~F} 12.4)$ & $\begin{array}{l}\text { Quão satisfeito(a) você está com sua } \\
\text { capacidade para o trabalho? }\end{array}$ & 1 & 2 & 3 & 4 & 5 \\
\hline 19(F6.3) & $\begin{array}{l}\text { Quão satisfeito(a) você está consigo } \\
\text { mesmo? }\end{array}$ & 1 & 2 & 3 & 4 & 5 \\
\hline $20(\mathrm{~F} 13.3)$ & $\begin{array}{l}\text { Quão satisfeito(a) você está com suas } \\
\text { relaÇões pessoais (amigos, parentes, } \\
\text { conhecidos, colegas)? }\end{array}$ & 1 & 2 & 3 & 4 & 5 \\
\hline 21(F15.3) & $\begin{array}{l}\text { Quão satisfeito(a) você está com sua } \\
\text { vida sexual? }\end{array}$ & 1 & 2 & 3 & 4 & 5 \\
\hline $22(\mathrm{~F} 14.4)$ & $\begin{array}{l}\text { Quão satisfeito(a) você está com o } \\
\text { apoio que você recebe de seus } \\
\text { amigos? }\end{array}$ & 1 & 2 & 3 & 4 & 5 \\
\hline 23(F17.3) & $\begin{array}{l}\text { Quão satisfeito(a) você está com as } \\
\text { condições do local onde mora? }\end{array}$ & 1 & 2 & 3 & 4 & 5 \\
\hline $24(\mathrm{~F} 19.3)$ & $\begin{array}{l}\text { Quão satisfeito(a) você está com o } \\
\text { seu acesso aos serviços de saúde? }\end{array}$ & 1 & 2 & 3 & 4 & 5 \\
\hline 25(F23.3) & $\begin{array}{l}\text { Quão satisfeito(a) você está com o } \\
\text { seu meio de transporte? }\end{array}$ & 1 & 2 & 3 & 4 & 5 \\
\hline
\end{tabular}

As questões seguintes referem-se a com que freqüência você sentiu ou experimentou certas coisas nas últimas duas semanas.

\begin{tabular}{||l|l|c|c|c|c|c|}
\hline \hline & nunca & $\begin{array}{c}\text { Algumas } \\
\text { vezes }\end{array}$ & freqüentemente & $\begin{array}{c}\text { muito } \\
\text { freqüentemente }\end{array}$ & sempre \\
\hline $26($ F8.1) & $\begin{array}{l}\text { Com que frequência você tem } \\
\text { sentimentos negativos tais como mau } \\
\text { humor, desespero, ansiedade, depressão? }\end{array}$ & 1 & 2 & 3 & 4 & 5 \\
\hline
\end{tabular}

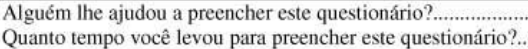

OBRIGADO PELA SUA COLABORAÇÃO 


\section{APÊNDICE VII}

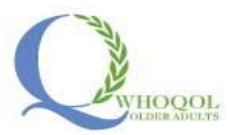

\section{WHOQOL-OLD}

Instruçōes

ESTE INSTRUMENTO NAO DEVE SER APLICADO INDIVIDUALMENTE, MAS SIM EM CONJUNTO COM O INSTRUMENTO WHOQOL-BREF

Este questionário pergunta a respeito dos seus pensamentos, sentimentos e sobre certos aspectos de sua qualidade de vida, e aborda questões que podem ser importantes para você como membro mais velho da sociedade.

Por favor, responda todas as perguntas. Se você não está seguro a respeito de que resposta dar a uma pergunta, por favor escolha a que lhe parece mais apropriada. Esta pode ser muitas vezes a sua primeira resposta.

Por favor tenha em mente os seus valores, esperanças, prazeres e preocupações. Pedimos que pense na sua vida nas duas últimas semanas.

Por exemplo, pensando nas duas últimas semanas, uma pergunta poderia ser :

O quanto você se preocupa com o que o futuro poderá trazer?

Nada

1
Muito pouco

2
Mais ou menos

3
Bastante
Extremamente

Você deve circular o número que melhor reflete o quanto você se preocupou com o seu futuro durante as duas últimas semanas. Então você circularia o número 4 se você se preocupou com o futuro "Bastante", ou circularia o número 1 se não tivesse se preocupado "Nada" com o futuro. Por favor leia cada questão, pense no que sente e circule o número na escala que seja a melhor resposta para você para cada questão.

Muito obrigado(a) pela sua colaboração! 
As seguintes questões perguntam sobre o quanto você tem tido certos sentimentos nas últimas duas semanas.

old_01 Até que ponto as perdas nos seus sentidos (por exemplo, audição, visão, paladar, olfato, tato), afetam a sua vida diária?

\begin{tabular}{c|c|c|c|c} 
Nada & Muito pouco & Mais ou menos & Bastante & Extremamente \\
1 & 2 & 3 & 4 & 5
\end{tabular}

old_02 Até que ponto a perda de, por exemplo, audição, visão, paladar, olfato, tato, afeta a sua capacidade de participar em atividades?

\begin{tabular}{c|c|c|c|c} 
Nada & Muito pouco & Mais ou menos & Bastante & Extremamente \\
1 & 2 & 3 & 4 & 5
\end{tabular}

old_03 Quanta liberdade você tem de tomar as suas próprias decisões?

\begin{tabular}{c|c|c|c|c} 
Nada & Muito pouco & Mais ou menos & Bastante & Extremamente \\
1 & 2 & 3 & 4 & 5
\end{tabular}

old_04 Até que ponto você sente que controla o seu futuro?

\begin{tabular}{c|c|c|c|c} 
Nada & Muito pouco & Mais ou menos & Bastante & Extremamente \\
1 & 2 & 3 & 4 & 5
\end{tabular}

old_05 O quanto você sente que as pessoas ao seu redor respeitam a sua liberdade?

\begin{tabular}{c|c|c|c|c} 
Nada & Muito pouco & Mais ou menos & Bastante & Extremamente \\
1 & 2 & 3 & 4 & 5
\end{tabular}

old_06 Quão preocupado você está com a maneira pela qual irá morrer?

\begin{tabular}{c|c|c|c|c} 
Nada & Muito pouco & Mais ou menos & Bastante & Extremamente \\
1 & 2 & 3 & 4 & 5
\end{tabular}

old_07 O quanto você tem medo de não poder controlar a sua morte?

\begin{tabular}{c|c|c|c|c} 
Nada & Muito pouco & Mais ou menos & Bastante & Extremamente \\
1 & 2 & 3 & 4 & 5
\end{tabular}

old_08 O quanto você tem medo de morrer?

\begin{tabular}{c|c|c|c|c} 
Nada & Muito pouco & Mais ou menos & Bastante & Extremamente \\
1 & 2 & 3 & 4 & 5
\end{tabular}


old_09 O quanto você teme sofrer dor antes de morrer?

\begin{tabular}{c|c|c|c|c} 
Nada & Muito pouco & Mais ou menos & Bastante & Extremamente \\
1 & 2 & 3 & 4 & 5
\end{tabular}

As seguintes questões perguntam sobre quão completamente você fez ou se sentiu apto a fazer algumas coisas nas duas últimas semanas.

old_10 Até que ponto o funcionamento dos seus sentidos (por exemplo, audição, visão, paladar, olfato, tato) afeta a sua capacidade de interagir com outras pessoas?

\begin{tabular}{c|c|c|c|c} 
Nada & Muito pouco & Médio & Muito & Completamente \\
1 & 2 & 3 & 4 & 5
\end{tabular}

old_11 Até que ponto você consegue fazer as coisas que gostaria de fazer?

\begin{tabular}{c|c|c|c|c} 
Nada & Muito pouco & Médio & Muito & Completamente \\
1 & 2 & 3 & 4 & 5
\end{tabular}

old_12 Até que ponto você está satisfeito com as suas oportunidades para continuar alcançando outras realizações na sua vida?

\begin{tabular}{c|c|c|c|c} 
Nada & Muito pouco & Médio & Muito & Completamente \\
1 & 2 & 3 & 4 & 5
\end{tabular}

old_13 O quanto você sente que recebeu o reconhecimento que merece na sua vida?

\begin{tabular}{c|c|c|c|c} 
Nada & Muito pouco & Médio & Muito & Completamente \\
1 & 2 & 3 & 4 & 5
\end{tabular}

old_14 Até que ponto você sente que tem o suficiente para fazer em cada dia?

\begin{tabular}{c|c|c|c|c} 
Nada & Muito pouco & Médio & Muito & Completamente \\
1 & 2 & 3 & 4 & 5
\end{tabular}


As seguintes questões pedem a você que diga o quanto você se sentiu satisfeito, feliz ou bem sobre vários aspectos de sua vida nas duas últimas semanas.

old_15 Quão satisfeito você está com aquilo que alcançou na sua vida?

Muito insatisfeito

1

$$
\text { Insatisfeito }
$$$$
\begin{gathered}
\text { Nem satisfeito nem } \\
\text { insatisfeito } \\
3
\end{gathered}
$$

Muito satisfeito

5

old_16 Quão satisfeito você está com a maneira com a qual você usa o seu tempo?

Muito insatisfeito

1

$$
\text { Insatisfeito }
$$$$
\left|\begin{array}{c}
\text { Nem satisfeito nem } \\
\text { insatisfeito } \\
3
\end{array}\right|
$$

Satisfeito

4

Muito satisfeito

old_17 Quão satisfeito você está com o seu nível de atividade?

Muito insatisfeito

1

$$
\text { Insatisfeito }
$$

2

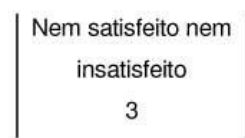

\section{Satisfeito}

4
Muito satisfeito

5

\begin{tabular}{|c|c|c|c|c|}
\hline Muito insatisfeito & Insatisfeito & Nem satisfeito nem & Satisfeito & Muito satisfeito \\
\hline 1 & 2 & $\begin{array}{c}\text { insatisfeito } \\
3\end{array}$ & 4 & 5 \\
\hline
\end{tabular}

old_18 Quão satisfeito você está com as oportunidades que você tem para participar de atividades da comunidade?

old_19 Quão feliz você está com as coisas que você pode esperar daqui para frente?

\begin{tabular}{c|c|c|c|c} 
Muito infeliz & Infeliz & Nem feliz & Feliz & Muito feliz \\
1 & 2 & nem infeliz & 4 & 5
\end{tabular}

old_20 Como você avaliaria o funcionamento dos seus sentidos (por exemplo, audição, visão, paladar, olfato, tato)?

\begin{tabular}{c|c|c|c|c} 
Muito ruim & Ruim & Nem ruim & Boa & Muito boa \\
1 & 2 & nem boa & 4 & 5
\end{tabular}


As seguintes questões se referem a qualquer relacionamento intimo que você possa ter. Por favor, considere estas questões em relação a um companheiro ou uma pessoa próxima com a qual você pode compartilhar (dividir) sua intimidade mais do que com qualquer outra pessoa em sua vida.

old_21 Até que ponto você tem um sentimento de companheirismo em sua vida?

\begin{tabular}{c|c|c|c|c} 
Nada & Muito pouco & Mais ou menos & Bastante & Extremamente \\
1 & 2 & 3 & 4 & 5
\end{tabular}

old_22 Até que ponto você sente amor em sua vida?

\begin{tabular}{c|c|c|c|c} 
Nada & Muito pouco & Mais ou menos & Bastante & Extremamente \\
1 & 2 & 3 & 4 & 5
\end{tabular}

old_23 Até que ponto você tem oportunidades para amar?

\begin{tabular}{c|c|c|c|c} 
Nada & Muito pouco & Médio & Muito & Completamente \\
1 & 2 & 3 & 4 & 5
\end{tabular}

old_24 Até que ponto você tem oportunidades para ser amado?

\begin{tabular}{c|c|c|c|c} 
Nada & Muito pouco & Médio & Muito & Completamente \\
1 & 2 & 3 & 4 & 5
\end{tabular}

VOCÊ TEM ALGUM COMENTÁRIO SOBRE O QUESTIONÁRIO?

OBRIGADO(A) PELA SUA COLABORAÇÃO! 


\section{APÊNDICE VIII}

Folha de Respostas - CAMCOG

DATA:

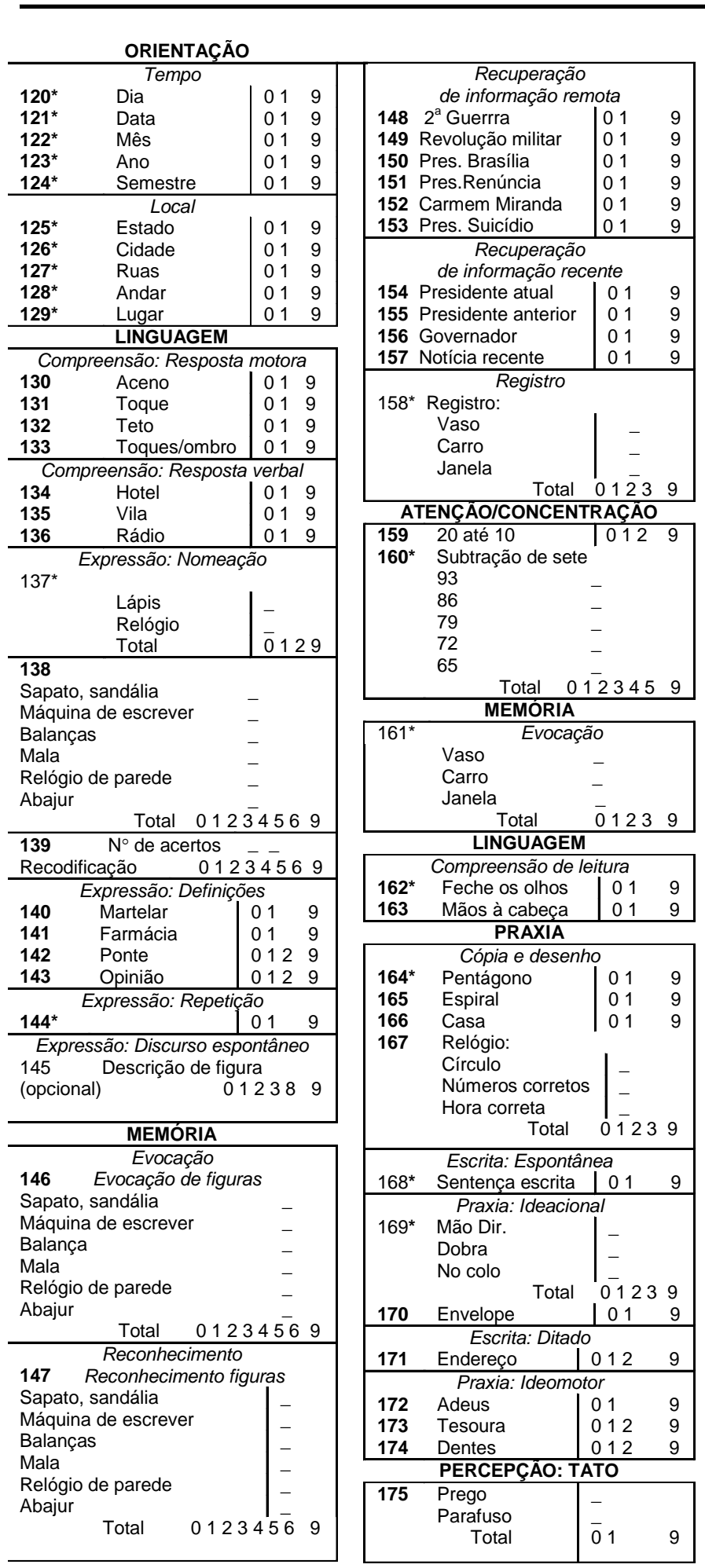

CÁLCULO

\begin{tabular}{|c|c|}
\hline $\begin{array}{l}176 \text { Cálculo1: Soma } \\
177 \text { Cálculo2: Troco }\end{array}$ & $\begin{array}{|ll|}01 & 9 \\
01 & 9\end{array}$ \\
\hline
\end{tabular}

MEMÓRIA: FIXAÇÁO

178 Nome e endereco

João

da Silva

Rua José Camargo

42

Perdizes

\begin{tabular}{l|l} 
Total & $01 \overline{23} 459$
\end{tabular}

PENSAMENTO ABSTRATO

179 Maçã e Banana 10129

180 Camisa e Vestido 0129

181 Mesa e Cadeira $\quad 0129$

182 Planta e Animal 01

PERCEPÇÃO VISUAL

\begin{tabular}{|ll|ll|}
\hline 183 & Pessoas famosas \\
Pelé & & \\
Papa & & & \\
& Total & 012 & 9 \\
\hline
\end{tabular}

Objetos Constância de objeto

184

Óculos

Sapato

Bolsa, Porta-níquel

Xícara e pires

Telefone

Cachimbo

Total

$\mid 012345 \overline{6} 9$

Reconhecimento de

pessoas/função

185 Reconhece pessoa $\mid \begin{array}{lll}0 & 9\end{array}$

PASSAGEM DE TEMPO

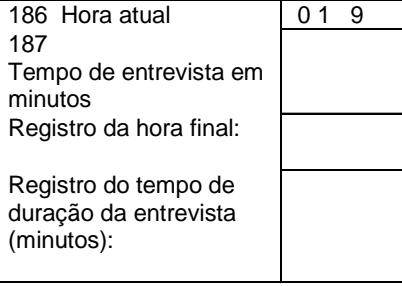

ENTREVISTADOR: 
APÊNDICE IX

Valores máximos para as subáreas do CAMCOG

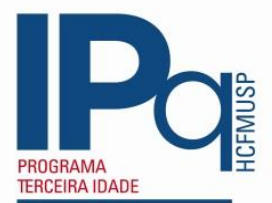

The Cambridge examination for mental disorders of the elderly

\section{CAMCOG}

Paciente:

IDADE:

RGHC:

Data de Avaliação:

Escolaridade:

CAMCOG TOTAL: 107

CAMCOG:

MEEM NO CAMCOG:

ORIENTAÇÃO: $\quad$ /10

LINGUAGEM: $\quad / 30$

MEMÓRIA: $\quad$ /27

ATENÇÃO/CONCETRAÇÃO: $\quad / 7$

PRAXIA: $\quad / 12$

CALCULO: $\quad / 2$

PENSAMENTO ABSTRATO: $\quad / 8$

PERCEPÇÃO TOTAL: $\quad$ /2

PERCEPÇÂO VISUAL: /9

Renné P. Alegria 


\section{APÊNDICE X}

Estudo da influência da prática com as artes cênicas e atividade autobiográfica e literária no comportamento de uma população com mais de 60 anos de idade.

Descrição das pontuações individuais por subáreas do CAMCOG dos voluntários (G1 e G2).

\begin{tabular}{|c|c|c|}
\hline Grupo 1 / voluntário & CAMCOG (INICIAL) & CAMCOG (FINAL) \\
\hline 6 & $\begin{array}{l}\text { 102 pontos } \\
\text { Orientação:10 } \\
\text { Linguagem:30 } \\
\text { Memória: } 23 \\
\text { Atenção:7 } \\
\text { Praxia :12 } \\
\text { Calculo:2 } \\
\text { Pensamento Abstrato:8 } \\
\text { Percepção: } 10 \\
\text { MEEM- Mini Exame do Estado } \\
\text { Mental: } 28 \text { pontos }\end{array}$ & $\begin{array}{l}\text { 102 pontos } \\
\text { Orientação: } 10 \\
\text { Linguagem:30 } \\
\text { Memória:23 } \\
\text { Atenção:7 } \\
\text { Praxia :12 } \\
\text { Calculo:2 } \\
\text { Pensamento Abstrato: } 8 \\
\text { Percepção: } 10 \\
\text { MEEM- Mini Exame do Estado } \\
\text { Mental: } 30 \text { pontos }\end{array}$ \\
\hline 8 & $\begin{array}{l}98 \text { pontos } \\
\text { Orientação: } 10 \\
\text { Linguagem: } 28 \\
\text { Memória: } 21 \\
\text { Atenção:7 } \\
\text { Praxia }: 12 \\
\text { Calculo: } 2 \\
\text { Pensamento Abstrato:8 } \\
\text { Percepção: } 10 \\
\text { MEEM- Mini Exame do Estado } \\
\text { Mental: } 28 \text { pontos }\end{array}$ & $\begin{array}{l}\text { 101 pontos } \\
\text { Orientação: } 10 \\
\text { Linguagem:28 } \\
\text { Memória: } 24 \\
\text { Atenção:7 } \\
\text { Praxia :12 } \\
\text { Calculo:2 } \\
\text { Pensamento Abstrato: } 8 \\
\text { Percepção: } 10 \\
\text { MEEM- Mini Exame do Estado } \\
\text { Mental: } 30 \text { pontos }\end{array}$ \\
\hline 12 & $\begin{array}{l}97 \text { pontos } \\
\text { Orientação: } 10 \\
\text { Linguagem: } 28 \\
\text { Memória: } 20 \\
\text { Atenção:7 } \\
\text { Praxia :12 } \\
\text { Calculo:2 } \\
\text { Pensamento Abstrato:8 } \\
\text { Percepção:10 } \\
\text { MEEM- Mini Exame do Estado } \\
\text { Mental: } 30 \text { pontos }\end{array}$ & $\begin{array}{l}91 \text { pontos } \\
\text { Orientação: } 10 \\
\text { Linguagem:28 } \\
\text { Memória:14 } \\
\text { Atenção:7 } \\
\text { Praxia :12 } \\
\text { Calculo:2 } \\
\text { Pensamento Abstrato: } 8 \\
\text { Percepção: } 10 \\
\text { MEEM- Mini Exame do Estado } \\
\text { Mental: } 28 \text { pontos }\end{array}$ \\
\hline 13 & $\begin{array}{l}\text { 103 } \\
\text { Orientação: } 10 \\
\text { Linguagem:30 } \\
\text { Memória: } 27 \\
\text { Atenção:6 } \\
\text { Praxia :12 } \\
\text { Calculo:2 } \\
\text { Pensamento Abstrato:6 } \\
\text { Percepção: } 10 \\
\text { MEEM- Mini Exame do Estado } \\
\text { Mental: } 29 \text { pontos }\end{array}$ & $\begin{array}{l}106 \\
\text { Orientação: } 10 \\
\text { Linguagem:30 } \\
\text { Memória:27 } \\
\text { Atenção:7 } \\
\text { Praxia :12 } \\
\text { Calculo:2 } \\
\text { Pensamento Abstrato:8 } \\
\text { Percepção:10 } \\
\text { MEEM- Mini Exame do Estado } \\
\text { Mental: } 30 \text { pontos }\end{array}$ \\
\hline
\end{tabular}




\begin{tabular}{|c|c|c|}
\hline Grupo 2 & $\begin{array}{l}\text { CAMCOG (INICIAL) } \\
\text { Pontuação máxima } 107\end{array}$ & $\begin{array}{l}\text { CAMCOG (FINAL) } \\
\text { Pontuação máxima } 107\end{array}$ \\
\hline 2 & $\begin{array}{l}98 \text { pontos } \\
\text { Orientação: } 10 \\
\text { Linguagem: } 27 \\
\text { Memória: } 24 \\
\text { Atenção7 } \\
\text { Praxia :12 } \\
\text { Calculo:2 } \\
\text { Pensamento Abstrato: } 8 \\
\text { Percepção: } 8 \\
\text { MEEM- Mini Exame do Estado } \\
\text { Mental: } 28 \text { pontos }\end{array}$ & $\begin{array}{l}99 \text { pontos } \\
\text { Orientação: } 10 \\
\text { Linguagem:28 } \\
\text { Memória: } 23 \\
\text { Atenção:7 } \\
\text { Praxia }: 12 \\
\text { Calculo:2 } \\
\text { Pensamento Abstrato:8 } \\
\text { Percepção:9 } \\
\text { MEEM- Mini Exame do Estado } \\
\text { Mental: } 30 \text { pontos }\end{array}$ \\
\hline 3 & $\begin{array}{l}\text { 103 pontos } \\
\text { Orientação:10 } \\
\text { Linguagem:30 } \\
\text { Memória: } 27 \\
\text { Atenção:7 } \\
\text { Praxia :12 } \\
\text { Calculo:2 } \\
\text { Pensamento Abstrato:8 } \\
\text { Percepção:7 } \\
\text { MEEM- Mini Exame do Estado } \\
\text { Mental: } 30 \text { pontos }\end{array}$ & $\begin{array}{l}\text { 100 pontos } \\
\text { Orientação: } 10 \\
\text { Linguagem:30 } \\
\text { Memória:24 } \\
\text { Atenção:7 } \\
\text { Praxia :12 } \\
\text { Calculo:2 } \\
\text { Pensamento Abstrato:8 } \\
\text { Percepção:7 } \\
\text { MEEM- Mini Exame do Estado } \\
\text { Mental: } 29 \text { pontos }\end{array}$ \\
\hline 5 & $\begin{array}{l}94 \text { pontos } \\
\text { Orientação: } 10 \\
\text { Linguagem: } 28 \\
\text { Memória: } 20 \\
\text { Atenção:7 } \\
\text { Praxia :11 } \\
\text { Calculo:2 } \\
\text { Pensamento Abstrato:7 } \\
\text { Percepção:9 } \\
\text { MEEM- Mini Exame do Estado } \\
\text { Mental: } 29 \text { pontos }\end{array}$ & $\begin{array}{l}\text { 101 pontos } \\
\text { Orientação: } 10 \\
\text { Linguagem: } 28 \\
\text { Memória: } 24 \\
\text { Atenção7 } \\
\text { Praxia }: 12 \\
\text { Calculo:2 } \\
\text { Pensamento Abstrato:8 } \\
\text { Percepção: } 10 \\
\text { MEEM- Mini Exame do Estado } \\
\text { Mental: } 30 \text { pontos }\end{array}$ \\
\hline 6 & $\begin{array}{l}96 \text { pontos } \\
\text { Orientação: } 10 \\
\text { Linguagem: } 28 \\
\text { Memória: } 22 \\
\text { Atenção:5 } \\
\text { Praxia }: 12 \\
\text { Calculo: } 1 \\
\text { Pensamento Abstrato: } 8 \\
\text { Percepção: } 10 \\
\text { MEEM- Mini Exame do Estado } \\
\text { Menta: } 27 \text { pontos }\end{array}$ & $\begin{array}{l}93 \text { pontos } \\
\text { Orientação: } 10 \\
\text { Linguagem: } 27 \\
\text { Memória: } 19 \\
\text { Atenção5 } \\
\text { Praxia }: 12 \\
\text { Calculo:2 } \\
\text { Pensamento Abstrato:8 } \\
\text { Percepção: } 10 \\
\text { MEEM- Mini Exame do Estado } \\
\text { Mental: } 28 \text { pontos }\end{array}$ \\
\hline 8 & \begin{tabular}{|l|}
97 pontos \\
Orientação: 10 \\
Linguagem:27 \\
Memória:23 \\
Atenção:5 \\
\end{tabular} & $\begin{array}{l}95 \text { pontos } \\
\text { Orientação:10 } \\
\text { Linguagem:27 } \\
\text { Memória:22 } \\
\text { Atenção7 }\end{array}$ \\
\hline
\end{tabular}




\begin{tabular}{|c|c|c|}
\hline & $\begin{array}{l}\text { Praxia :12 } \\
\text { Calculo:2 } \\
\text { Pensamento Abstrato:8 } \\
\text { Percepção: } 10 \\
\text { MEEM- Mini Exame do Estado } \\
\text { Mental: } 27 \text { pontos }\end{array}$ & $\begin{array}{l}\text { Praxia :12 } \\
\text { Calculo:2 } \\
\text { Pensamento Abstrato:8 } \\
\text { Percepção:7 } \\
\text { MEEM- Mini Exame do Estado } \\
\text { Mental: } 29 \text { pontos }\end{array}$ \\
\hline 9 & \begin{tabular}{|l|}
103 pontos \\
Orientação: 10 \\
Linguagem:30 \\
Memória: 24 \\
Atenção:7 \\
Praxia :12 \\
Calculo:2 \\
Pensamento Abstrato:8 \\
Percepção: 10 \\
MEEM- Mini Exame do Estado \\
Mental: 30 pontos
\end{tabular} & $\begin{array}{l}\text { 105 pontos } \\
\text { Orientação: } 10 \\
\text { Linguagem:30 } \\
\text { Memória:26 } \\
\text { Atenção:7 } \\
\text { Praxia :12 } \\
\text { Calculo:2 } \\
\text { Pensamento Abstrato:8 } \\
\text { Percepção: } 10 \\
\text { MEEM- Mini Exame do Estado } \\
\text { Mental: } 30 \text { pontos }\end{array}$ \\
\hline 12 & $\begin{array}{l}\text { 101 pontos } \\
\text { Orientação:8 } \\
\text { Linguagem:29 } \\
\text { Memória: } 25 \\
\text { Atenção7 } \\
\text { Praxia : } 12 \\
\text { Calculo:2 } \\
\text { Pensamento Abstrato:8 } \\
\text { Percepção:10 } \\
\text { MEEM- Mini Exame do Estado } \\
\text { Mental: } 28 \text { pontos }\end{array}$ & $\begin{array}{l}\text { 101 pontos } \\
\text { Orientação: } 10 \\
\text { Linguagem:28 } \\
\text { Memória:24 } \\
\text { Atenção:7 } \\
\text { Praxia :12 } \\
\text { Calculo:2 } \\
\text { Pensamento Abstrato:8 } \\
\text { Percepção: } 10 \\
\text { MEEM- Mini Exame do Estado } \\
\text { Mental: } 28 \text { pontos }\end{array}$ \\
\hline 14 & $\begin{array}{l}\text { 101 pontos } \\
\text { Orientação:9 } \\
\text { Linguagem:27 } \\
\text { Memória: } 26 \\
\text { Atenção:7 } \\
\text { Praxia }: 12 \\
\text { Calculo:2 } \\
\text { Pensamento Abstrato:8 } \\
\text { Percepção: } 10 \\
\text { MEEM- Mini Exame do Estado } \\
\text { Mental: } 27 \text { pontos }\end{array}$ & $\begin{array}{l}\text { 102 pontos } \\
\text { Orientação:10 } \\
\text { Linguagem:29 } \\
\text { Memória:25 } \\
\text { Atenção:6 } \\
\text { Praxia :12 } \\
\text { Calculo:2 } \\
\text { Pensamento Abstrato:8 } \\
\text { Percepção: } 10 \\
\text { MEEM- Mini Exame do Estado } \\
\text { Mental: } 29 \text { pontos }\end{array}$ \\
\hline
\end{tabular}

- $\mathrm{MEEM}=$ Mini Exame do Estado Mental tem pontuação máxima de 30. 


\section{APÊNDICE XI}

Estudo da influência da prática com as artes cênicas e atividade autobiográfica e literária no comportamento de uma população com mais de 60 anos de idade.

\section{Questionário de avaliação do curso}

Nome

Idade

1. Qual a sua avaliação sobre o curso?

2. Comente sobre o processo de trabalho desenvolvido durante o curso.

3. O que você aprendeu neste curso?

4. Cite alguns temas, vocábulos e aspecto técnico do teatro que você aprendeu a partir do curso.

5. Quais são as partes do seu corpo que mais chamam a sua atenção agora?

6. Cite algumas partes do seu corpo que não lhe eram percebidas antes do curso.

7. Depois que você fez o curso, seu relacionamento com a família mudou? De que forma?

8. E com os amigos, houve alguma diferença no relacionamento?

9. Dentre todas as atividades do curso, o que chamou mais a sua atenção?

10. E o que você mais gostou?

11. Qual foi o momento mais marcante do curso?

12. Sem perguntar ou olhar para eles, escreva o nome de todos os colegas do curso.

13. Dê seu depoimento sobre o curso, no geral.

14. Você percebe alguma alteração física no seu corpo após o curso?

15. Você acha que houve alguma melhora física em relação ao seu corpo?

16. O que você não fazia e agora faz após o início do curso? 


\section{APÊNDICE XII}

Estudo da influência da prática com as artes cênicas e atividade autobiográfica e literária no comportamento de uma população com mais de 60 anos de idade.

\section{QUESTIONÁRIO COM 8 PERGUNTAS}

\section{ENTREVISTA COM VÍDEO}

Data 20 de dezembro de 2011

NOME

IDADE

1. O que te levou a fazer essa atividade?

2. Você já tinha feito teatro ou dança antes?

3. O que essa atividade é para você agora?

4. Você se sente diferente agora depois que fez essa atividade? Em quê, como?

5. Como está sua relação com amigos e familiares?

6. E a relação com os colegas do curso, como você a sente?

7. O que é esse grupo de teatro e dança para você neste momento?

8. O que você achou da atividade e sua participação nela? 


\section{APÊNDICE XIII}

Estudo da influência da prática com as artes cênicas e atividade autobiográfica e literária no comportamento de uma população com mais de 60 anos de idade.

\section{QUESTIONÁRIO COM 4 PERGUNTAS}

\section{Entrevista de encerramento da atividade (gravação em vídeo)}

Nome:

Idade:

Perguntas

1. O que você achou de ter participado do espetáculo Histórias de Mulheres?

2. Foi a primeira vez que você se apresentou para o público de teatro? Qual é a sensação desse momento?

3. A atividade cumpriu a proposta?

4. Você deseja continuar

$(14 / 02 / 2011)$ 
APÊNDICE XIV - Questionário Avaliação Final - Escala Likert (G2)

Estudo da influência da prática com as artes cênicas e atividade autobiográfica e literária no comportamento de uma população com mais de 60 anos de idade.

Nome:

Idade:

Instruções . Após o término da Atividade

de artes cênicas - Só com Experiência,

como você avalia seu corpo hoje quanto a:

$(0)$

Não melhorou

Melhorou pouco Teve razoável

Teve razoável Teve boa

Teve ótima

Teve Excelente

1. Postura

2. Movimento

3. Flexibilidade

4. Atenção

5. Memória

6. Motivação

7. Estado emocional

8. Relacionamento com o grupo

9. Relacionamento com a família

10. Relacionamento com amigos

11. Saúde 


\section{APÊNDICE XV}

Estudo da influência da prática com as artes cênicas e atividade autobiográfica e literária no comportamento de uma população com mais de 60 anos de idade.

\section{FICHA TRIAGEM - IDOSOS}

$\mathbf{N}^{\mathbf{o}}$

1. Nome:

Masculino (.)

Feminino (.)

Nascimento.................................

Idade.

Data da triagem/aplicação de testes ........................................

One-Leg Balance (VELLAS BJ, WAYNE SJ, ROMERO L, BAUMGARTNER RN, Rubenstein LZ, GARRY PJ, 1997)

Instrução: sujeito em pé, estabiliza seu corpo sobre as duas pernas, usando calçados usuais. Depois, com ajuda do aplicador do teste, estabiliza seu corpo sobre uma perna - aquela em que tem mais dificuldade, ou seja, se destro, fica sobre a perna esquerda; se canhoto, a perna a ser utilizada é a direita. Estabilizado sobre uma das pernas, o aplicador retira seu apoio e anuncia o comando "agora". Nesse momento o cronômetro é acionado, que só deve parar quando verificado qualquer fator de desequilíbrio.

A) Tempo gasto na tarefa ( $1^{\underline{a}}$ tentativa): segundos

B) Tempo gasto na tarefa ( $2^{\underline{a}}$ tentativa): segundos ..Horário do teste

Observações (se houver):

Obrigado 


\section{APÊNDICE XVI}

Estudo da influência da prática com as artes cênicas e atividade autobiográfica e literária no comportamento de uma população com mais de 60 anos de idade.

\section{FICHA TRIAGEM - IDOSOS}

$$
\mathbf{N}^{\circ}
$$

\section{Nome:}

\section{Masculino (.) \\ Feminino (.)}

Nascimento.................................

Idade.

Data da triagem/aplicação de testes .......................................

--- TIMED UP \& GO TEST (TUGT) (Podsiadlo\& Richardson, 1991)

Instrução: sujeito sentado em uma cadeira com braços, as costas apoiadas, usando seus calçados usuais e seu dispositivo de auxílio à marcha (se houver). Após o comando "vá", deve se levantar da cadeira e andar um percurso linear de 3 m, com passos seguros, retornar em direção à cadeira e sentar-se novamente.

C) Tempo gasto na tarefa ( $1^{\text {a }}$ tentativa): segundos

D) Tempo gasto na tarefa ( $2^{\underline{a}}$ tentativa): segundos

..Horário do TUGT

Observações sobre a marcha (se houver): 
TIMED UP \& |GO TEST com dupla tarefa (falando)

E) Tempo gasto na tarefa $\left(1^{\underline{a}}\right.$ tentativa): segundos

F) Tempo gasto na tarefa ( $2^{-a}$ tentativa) segundos

.. Horário do TUGT

..Observações sobre a marcha (se houver):

\section{SIX Minute Walk TEST}

(Raquel Rodrigues Britto e Lidiane Aparecida Pereira de Souza, 2006)

Altura

Idade

Peso

Distância percorrida em seis minutos:

Obrigado! 


\section{APÊNDICE XVII}

Estudo da influência da prática com as artes cênicas e atividade autobiográfica e literária no comportamento de uma população com mais de 60 anos de idade.

\section{DEPOIMENTO 1}

\section{O QUE FAÇO ATUALMENTE E POR QUE RESOLVI FAZER TEATRO - G2}

Voluntário 1 - 60 anos.

\begin{tabular}{|l|l|}
\hline Resposta original x expressões-chave & Ideias Centrais \\
\hline Meu objetivo em me candidatar a esta iniciativa tem a ver & 1) busca de espaço e liberdade \\
com um “espaço" a ser conquistado, próprio e isento de & 2) aberto a novos processos e convívio \\
$\begin{array}{l}\text { análises, onde eu possa me expressar livre e sendo EU } \\
\text { mesmo, solto de pressões sociais, políticas, de valores } \\
\text { alienígenas. Atualmente estou em fase de aposentadoria e em } \\
\text { vias de novas descobertas, novos rumos, novos desafios . }\end{array}$ & \\
\hline
\end{tabular}

Voluntário 2 - 67 anos de idade

\begin{tabular}{|c|c|}
\hline Resposta original $\mathrm{x}$ expressões-chave & Ideias Centrais \\
\hline $\begin{array}{l}\text { Atualmente eu cuido de mim, o que já me leva um bom temp } \\
\text { e me dá um bocado de trabalho. Esse cuidar de mim é o } \\
\text { trabalho forçado de uma dona de casa: limpar a casa, lavar e } \\
\text { passar roupa, fazer compra em supermercado, cozinhar. } \\
\text { Esclareço que até bem pouco tempo, eu era "filha”. Minha } \\
\text { mãe é que cuidava de mim e um belo dia ela me deixou... } \\
\text { Vamos às coisas que faço com prazer: faço musculação } 3 \text { x } \\
\text { por semana para manter a forma e para que eu possa andar at } \\
\text { os } 90 \text { anos sem precisar de apoio! } \\
\text { Estou fazendo um curso rápido de Tai chi, o que pretendo } \\
\text { continuar, um seminário cujo título é "Elogio à preguiça”, o } \\
\text { que está sendo um desafio para a minha capacidade de } \\
\text { entendimento. Participo de um clube de leitura, onde, } \\
\text { mensalmente é proposta a leitura de um livro e depois } \\
\text { debatido por um especialista ou pelo próprio autor. O outro } \\
\text { evento mensal em que participo é o cinema debate: } \\
\text { assistimos ao filme e depois o debatemos. Fora isso, eu vou a } \\
\text { shows, teatro e cinema. Em casa, às vezes sigo uma novela } \\
\text { quando ela me interessa, como é o caso de “Cordel } \\
\text { Encantado", que é uma mistura de personagens literários e } \\
\text { cinematográficos. Com relacão ao teatro o que posso dizer? }\end{array}$ & $\begin{array}{l}\text { 1) Assume cuidar de si, mas sente como uma tarefa } \\
\text { árdua e recente } \\
\text { 2) sua mãe faleceu recentemente e ela deixou de ser } \\
\text { "filha" } \\
\text { 3) faz muitas atividades para envelhecer com melhor } \\
\text { "qualidade de vida" } \\
\text { 4) o teatro é fascinação e curiosidade. Um desafio a } \\
\text { eser experimentado. }\end{array}$ \\
\hline
\end{tabular}


Bem, estou sempre à procura de algo que me proporcione um desenvolvimento intelectual e físico; algo que possa melhorar a minha qualidade de vida. Outra coisa: o fazer teatral sempre me fascinou, sempre me despertou a curiosidade. Penso que este curso possa me proporcionar o que foi exposto e por que não tentar? É mais um desafio.

Voluntário 4 - 60 anos de idade.

\begin{tabular}{|l|l|}
\hline Resposta original x expressões-chave & Ideias Centrais \\
\hline Sempre tive vontade de praticar atividades ligadas a & 1) vontade e disponibilidade e disposição para fazer \\
manifestações artísticas, e atualmente disponho de uma & atividades artísticas \\
disponibilidade de tempo e disposição que motivam & encara a atividade como oportunidade \\
fortemente o aproveitamento desta oportunidade. Tomando & \\
conhecimento deste projeto, e tendo uma solução para um & \\
problema de logística, coloco-me entusiasmadamente como & \\
participante. & \\
\hline
\end{tabular}

Voluntário 5 - 63 anos de idade

\begin{tabular}{|l|l|}
\hline Resposta original $x$ expressões-chave & Ideias Centrais \\
\hline Sou aposentada do trabalho profissional atualmente. A partir & 1) aposentada \\
do tempo que tenho livre procuro conhecer o que não fiz e & 2) tempo disponível \\
não tive tempo antes. & 3) fazer o que não fez antes \\
\hline
\end{tabular}

Voluntário 8 - 76 anos de idade

\begin{tabular}{|l|l|}
\hline Resposta original x expressões-chave & Ideias Centrais \\
\hline Sou aposentada faço dança espanhola caminhada resolvi & 1) aposentada \\
fazer teatro porque sempre gostei de ter bastante atividades e & \\
uma colega que faz teatro aqui comentou que estava & 2) gosta de ter bastante atividades \\
gostando muito e que eu poderia fazer também e que estava & \\
tendo vagas & \\
\hline
\end{tabular}

Voluntário 9 - 70 anos de idade

\begin{tabular}{|l|l|}
\hline Resposta original x expressões-chave & Ideias Centrais \\
\hline Atualmente sou professora aposentada. Fui professora de & 1) professora universitária aposentada \\
Química da USP e nos últimos 13 anos da UFBA. No & 2) no momento perdida e querendo fazer várias coisas \\
momento estou bastante perdida, pois quero fazer várias \\
$\begin{array}{l}\text { coisas. Sempre gostei muito de teatro, tanto para assistir } \\
\text { como para participar de apresentações. Fiz em 1999 um } \\
\text { curso “Todo mundo faz teatro", cujo professor, Felinto }\end{array}$ & $\begin{array}{l}\text { 3) já fez teatro e aplicou no ensino de química por } \\
\text { meio dos estudos de Viola Spolin (Improvisações }\end{array}$ \\
\hline
\end{tabular}


Coelho, utilizava as ideias de Viola Spolin. Ao final (4 meses) fizemos uma apresentação, que foi um sucesso! Comprei o livro de Improvisações teatrais de Viola Spolin e tentei aplicar no ensino de Química. Tive um relativo sucesso. Fazer teatro na $3^{\mathrm{a}}$ idade foi algo que não havia passado pela minha cabeça, mas, assim que vi a proposta, tive a certeza que seria algo que eu gostaria de fazer. Trabalhar a sociabilidade e comunicação, o corpo e a memória é tudo de bom. teatrais)

4) não pensou em fazer teatro na $3^{a}$ Idade, mas quer trabalhar a sociabilidade, comunicação, corpo e memória.

Voluntário 12 - 66 anos de idade

\begin{tabular}{|l|l|}
\hline Resposta original x expressões-chave & Ideias Centrais \\
\hline Atualmente não estou fazendo nada no sentido de sair da & 1) considera-se ociosa, sem sair da rotina. Cuida da \\
rotina, fico em casa, cuido dos afazeres e de uma filha que & casa e da filha que estuda e trabalha. \\
estuda e trabalha. Resolvi fazer teatro porque este foi sempre & \\
o sonho para mim. Na minha infância já participava de & 2) fazer teatro sempre foi um sonho \\
brincadeiras de teatro. Agora soube deste projeto e resolvi & \\
participar. Acho que poderá me trazer benefícios, tanto saúde & 3) resolver fazer por achar que trará benefícios tanto \\
de corpo pra mente. (Estou feliz por ter tido esta chance). & para a saúde do corpo como para a mente. \\
\hline
\end{tabular}

Voluntário 14 - 69 anos de idade

\begin{tabular}{|l|l|}
\hline Resposta original x expressões-chave & Ideias Centrais \\
\hline Atualmente sou dona de casa. O teatro foi por acaso: & 1) dona de casa \\
conversando com uma senhora, enquanto fazíamos & 2) devido ao entusiasmo de alguém, resolver fazer \\
canudinho de papel numa aula de reciclagem. Ela falou com & teatro. \\
tanto entusiasmo, que minha irmã e eu fomos direto para o & \\
teatro da Estação Ciência. & \\
\hline
\end{tabular}

Voluntário 16 - 80 anos de idade

\begin{tabular}{|l|l|}
\hline Resposta original x expressões-chave & Ideias Centrais \\
\hline Eu faço coral, já fiz aula de teatro, por isso vim procurar o & 1) coralista \\
seu teatro, me sinto bem, me dá alegria, estou muito feliz. & 2) fez teatro e por isso mesmo se inscreveu \\
& 3) sente-se bem, alegre e está muito feliz \\
\hline
\end{tabular}




\section{APÊNDICE XVIII \\ Estudo da influência da prática com as artes cênicas e atividade autobiográfica e literária no comportamento de uma população com mais de 60 anos de idade. \\ DEPOIMENTO 2 - Narrativa \\ UM FATO MARCANTE NA MINHA VIDA - G2}

Voluntário 1- 60 anos de idade

Idade: 3 anos

Tempo: Natal

Cena: manhã, presentes, árvore, carrinho com buzina e faróis, pedaleira, um só ocupante, tipo jipe-exército.

Local: casa térrea, isolada com muito quintal e jardim, cimentada toda a volta e o passeio. Mato à volta. Pego carrinho p/ "passear"e todos escutam buzina - Pipi insistente. Alguém resolve olhar e lá estou eu inaugurando a buzina do "jipe", pedindo "passagem" p/ uma cobra-coral estacionada no meio da calçada! O carrinho tornou-se um acessório vital na minha vida - aos quatorze já tinha uma cabine intacta, sem dianteira nem trazeira de um Gordini, após um acidente. Interromperam novamente minha "passeada” com o meu bólido! Assim é a vida!

Voluntário 2 - 67 anos de idade

Falarei de um fato marcante em minha vida bem recente. Aconteceu no dia 21/10/11, quando eu tive o privilégio de assistir o espetáculo teatral “Os náufragos da louca esperança”, uma criação coletiva do Theatre Du Soleil França. Sua diretora, Ariane Mnouchkine, é uma criatura adorável; dialoga conosco (público) como se estivesse em casa, fazendo-nos rir com seu bom humor. Antes de entrar na plateia, passamos pela sala de maquiagem, onde os atores dão os últimos retoques, antes de entrar em cena. Inicia o espetáculo: é indescritível; o palco é enorme e a movimentação dos atores é algo mágico. A troca de cenário, troca mesmo, é feita rapidamente; eles tiram tudo de cena, limpam o palco, para, então, efetuar a montagem de um novo; neste trabalho todos entram na dança, sem exceção. Não existe estrelismo. Tudo é feito normalmente, as peças sobem através de cordas e roldanas e presas em ganchos no chão. O espetáculo é divertido, é trágico, e triste, é político; é um espetáculo maravilhoso que, tenho certeza absoluta, não esquecerei e ficarei à espera de que voltem brevemente ao Brasil. Só um detalhe: a duração é de quase 4 horas. Nesse período você mergulha na magia da encenação que nem sente.

Voluntário 3 - 70 anos de idade

O prof. Cauê Matos ministra artes cênicas para a $3^{3}$ Idade na Estação Ciências em São Paulo, solicitou que cada pessoa do curso fizesse um relato de um fato marcante em sua vida. Bom, um fato que marcou minha vida foi o encontro com Vilma Rizzo, com quem casei em 22 de fevereiro de 1975. Deste encontro nasceram três filhos: Gustavo, Fábio e Adriana Rizzo de Aguiar. Atualmente todos adultos com mais de 30 anos. Eu e Vilma continuamos casados, bem casados, e numa caminhada recheada de lutas e vitórias, mas abençoados graças ao Amor de Deus para conosco. Posso afirmar que hoje aos 70 anos casaria com Vilma novamente e continuaria a jornada. Nestes 36 de vida juntos pudemos viver, chorar, brigar e amar sem deixar de sermos duas pessoas envolvidas com o bem comum. Tenho duas netas maravilhosas, Maria Carolina de Paula Aguiar, com 9 anos, e Mariana de Paula Aguiar, 4 anos, filhas do Gustavo e Vera.

Voluntário 4 - 60 anos de idade 
Sim, todo garoto, quando na fase dos 10 anos de idade, gosta de jogar bola. Não sendo nenhuma exceção, eu também pleiteava meu lugar no rol dos grandes craques, pois o Brasil acabava de obter o seu $1^{\circ}$ título Mundial. E, claro, tentava jogadas de efeito, para obter os aplausos. Foi assim que tive o meu contato com a "bicicleta". Consequência: a primeira fratura no meu braço direito! O que doeu mais foi colocar o osso no lugar, pois eu não queria levar bronca do meu pai, apesar da dor e do inchaço, na hora. Só depois do almoço, quando o braço já estava arroxeando e muito inchado, é que acabei "confirmando" o acidente. Foram trinta dias conhecendo os dois tipos básicos de gesso que se usava na época, a minha primeira vez com as fraturas.

Voluntário 5 - 63 anos de idade

Era costume no interior de Minas Gerais os fazendeiros visitarem os amigos utilizando os seus belos cavalos.

Havia também encontro dos fazendeiros criadores de gado negociando partidas de bezerros etc. Os negócios eram selados com palavras e a firmação moral do cumprimento do acertado era feita com cuspe. Os encontros sempre com muita cordialidade eram agradecidos de ambas as partes.

Voluntário 6-61 anos de idade

Um fato que marcou muito a minha vida foi o nascimento de minha filha. Foi o dia mais alegre de minha vida quando despertei no hospital e a enfermeira me trouxe uma linda menininha embrulhadinha numa manta amarela. Significou um amor novo, imenso no meu coração, o seguimento de uma vida. Rezei para Deus a proteger sempre aquele ser tão frágil e doce que mamava no meu seio. Para mim foi uma alegria sem fim. Nossa família se iluminou e nos unimos mais ainda. Meus pais contentes de serem avós. Pude sentir durante nove meses o pulsar de um novo ser dentro de mim, éramos um só coração e senti muito amor e entrega. Hoje já fazem 35 anos que se passaram, porém o meu sentimento continua sempre crescendo por esse milagre, que é o nascimento de um novo ser.

Voluntário 8 - 76 anos de idade

Sempre tive vontade de andar a cavalo. Até que um dia fui convidada para ir a um sítio. Era um domingo lindo, cheio de sol, todos estávamos muito contentes, depois de churrasco e das caipirinhas a turma foi andar a cavalo; insistiram para eu montar, estava com medo, mas a vontade era mais forte e disseram que o cavalo era manso então eu aceitei, montei e o cavalo não saía do lugar, por mais que eu insistisse. Até que o dono fizesse um gesto com a boca e com as mãos. O cavalo disparou, e eu em cima dele gritando para cavalinho, para, até que eu cai. Nunca mais quis montar, passou a vontade.

\section{Voluntário 12 - 66 anos de idade}

Um fato que marcou muito para mim, aconteceu lá na minha infância. Morava com meu pai, em fazendas, ele gostava muito de ir pescar nos finais de tarde. às vezes eu o acompanhava, apesar dos medos que eu sentia, bichos, principalmente cobras... Em uma destas, eu quis ir, meu pai concordou, fiquei feliz... Corri pegar minha "tralha", botas, chapéu... me achando né? Corria na frente toda contente. Lá chegando meu pai me colocou em um barranco mais ou menos limpo, então me ajeitei enquanto ele seguia à procura de um bom lugar pra ele ficar também. Joguei o anzol e fiquei ali à espera de que algum peixinho viesse. De repente senti fortes puxões na vara 
e o peixe me pareceu bem esperto, grande e esperto... Se debatia tanto, eu corria de um lado para o outro tentando segurar, quando consegui levantar a vara o que eu vi não era um peixe, mais a meu ver era uma cobra que pulava muito então saí correndo puxando aquela vara, levando tudo que estava a minha frente, gritando por meu pai, caí morro abaixo, meu pai que já não se continha de tanto de tanto rir, pegou a vara, olhou bem e disse se tratar de uma espécie de enguia que não oferecia nenhum perigo. Fiquei mais aliviada, mas até hoje não sou chegada a pescarias, jamais tiro um peixe do anzol. Me marcou muito este fato.

Voluntário 14 - 69 anos idade

A vida nos traz vários fatos marcantes. Escolhi um episódio que, depois do nascimento dos filhos, considero dos mais marcantes. A Ana terminou o $2^{\circ}$ grau mas, por fatos ocorridos na época, acabou não prestando vestibular. No ano seguinte, foi a vez da Amanda, que saiu do colegial louca para entrar num curso que ela já amava: jornalismo! Comprei os manuais do estudante de duas universidades públicas: USP e UNESP. Cheguei em casa feliz como se fosse o maior presente. Elas pularam de alegria e dançaram com os manuais. Os dias seguintes foram de muita ansiedade. Depois das provas, a angústia foi pela espera dos resultados. No dia da publicação da lista de aprovados, levantei cedo e fui comprar o jornal, ao chegar elas já aguardavam ansiosas. Fui para a cozinha fazer o café, enquanto as meninas procuravam seus nomes nas listas. Ouvi gritos emocionados corri e as abracei chorando. A Ana ingressou na faculdade de artes em S.P. e a Amanda foi para Bauru aos 17 anos, realizar seu sonho de ser jornalista.

Voluntário 16 - 80 anos de idade

Um fato importante para mim foi quando fui premiada, a Miss $3^{\text {a }}$ Idade. Outro foi quando participei no teatro, esses fatos eu trago sempre na minha memória. 


\section{APÊNDICE XIX}

Estudo da influência da prática com as artes cênicas e atividade autobiográfica e literária no comportamento de uma população com mais de 60 anos de idade.

\section{QUESTIONÁRIO COM 8 PERGUNTAS (ENTREVISTA EM VIDEO)}

\begin{tabular}{|c|c|c|c|c|c|}
\hline Pergunta & Voluntário & 2 & 3 & 5 & 6 \\
\hline \multicolumn{2}{|c|}{$\begin{array}{l}1 \text { - O que te levou a fazer } \\
\text { essa atividade }\end{array}$} & $\begin{array}{l}\text { Olha, eu sempre gostei muito de teatro, } \\
\text { eu sempre fui a teatro e foi uma } \\
\text { oportunidade. Eu queria ter uma } \\
\text { oportunidade de saber como era do outro } \\
\text { lado, né. E mais o que me trouxe aqui } \\
\text { realmente foi a proposta do curso em si, } \\
\text { não sei se, se eu posso considerar isso } \\
\text { como curso? É um curso! Ah...com a } \\
\text { proposta do curso a princípio que eu, que } \\
\text { eu li na programação da USP pra terceira } \\
\text { idade né que seriamos, serviria para um } \\
\text { estudo né. E isso me, me, me...foi mais } \\
\text { isto que me trouxe aqui. }\end{array}$ & $\begin{array}{l}\text { Necessidade de conhecer um pouco das artes } \\
\text { cênicas e melhorar a performance dos músculos, } \\
\text { ossos, etc. Melhorar o movimento melhorar a } \\
\text { dinâmica. }\end{array}$ & $\begin{array}{l}\text { As coisas começam até meio por acaso ou por } \\
\text { teimosia. A teimosia, é, adoro teatro eu } \\
\text { assistindo atores no palco, mas desta vez eu } \\
\text { falei vou fazer alguma coisa que eu achava } \\
\text { que eu não precisava pensar, chego aqui o } \\
\text { meu... A minha cabeça pensa e pensa muito e } \\
\text { aí eu vejo que eu domino meu corpo. }\end{array}$ & \begin{tabular}{|l|} 
Uma amiga minha ela me, me \\
convidou a assistir eu assisti e \\
gostei e vim fazer de que...por \\
causa do movimento também, da \\
flexibilidade. Ela já fazia aí eu \\
assisti uma, uma apresentação e \\
gostei, gostei.
\end{tabular} \\
\hline \multicolumn{2}{|c|}{$\begin{array}{l}\text { - Você já tinha feito } \\
\text { teatro ou dança antes? }\end{array}$} & \begin{tabular}{|l|} 
Dança sim, teatro fiz mas foi muito, \\
muito rudimentar no ensino de teatro que \\
eu fiz. Mas dança eu fiz alguma coisa \\
depois de adulta eu já tinha uns 35 anos \\
quando eu comecei.. quando entrei no \\
curso de dança, entrei no curso de dança, \\
sempre foi no curso de dança, sempre \\
fui, fui amadora mas a gente tinha um \\
grupinho de dança que nós éramos \\
muito... audaciosos, a professora \\
principalmente era muito audaciosa. Nós \\
fizemos apresentações e teatro, mas sim \\
tudo, tudo amadoristicamente, mas foi \\
uma época muito boa. Sim com relação a \\
corpo ao... sim, com relação ao corpo \\
também eu, eu comecei a mexer com \\
meu corpo, eu não parei mais! (risos)
\end{tabular} & Não, nunca tive contato. & unca. & $\begin{array}{l}\text { Eu fiz teatro mas fiz só um mês a } \\
\text { muito tempo atrás. Já tive } \\
\text { contato. }\end{array}$ \\
\hline
\end{tabular}




\begin{tabular}{|c|c|c|c|c|}
\hline $\begin{array}{l}3 \text { - O que é essa atividade } \\
\text { para você agora? }\end{array}$ & $\begin{array}{l}\text { É uma atividade muito prazerosa. Eu } \\
\text { acho que tá me trazendo muita coisa, } \\
\text { muita coisa boa. Atualmente estou } \\
\text { vencendo alguns, alguns, alguns medos, } \\
\text { alguns limites e, e, eu acho que é isso } \\
\text { (risos) }\end{array}$ & $\begin{array}{l}\text { Uma atividade que tem uma importância, muito } \\
\text { grande hoje. Eu posso dizer o seguinte, que me } \\
\text { beneficiou em vários aspectos né, aspectos de } \\
\text { dinâmica, movimento, raciocínio etc. Hoje eu } \\
\text { considero o exercício, atividade importante pra } \\
\text { manutenção da vida }\end{array}$ & É uma provação maravilhosa. & $\begin{array}{l}\text { Ah, ela é muito importante, } \\
\text { porque ela me mobiliza, ela me } \\
\text { faz pensar, me faz agir, me } \\
\text { mobiliza os movimentos, } \\
\text { exterioriza, tá, a parte interna da } \\
\text { gente. }\end{array}$ \\
\hline $\begin{array}{l}4 \text { - Você se sente diferente } \\
\text { agora depois que fez essa } \\
\text { atividade? Em que, como? }\end{array}$ & $\begin{array}{l}\text { Sim, e acho que eu cresci um pouquinho } \\
\text { não em tamanho mas (risos) no tamanho } \\
\text { talvez eu até né, posso ter crescido, mas } \\
\text { eu acho que eu aprendi alguma coisa } \\
\text { principalmente a conviver, a, a } \\
\text { convivência com as pessoas desse grupo } \\
\text { foi muito boa pra mim e com vocês } \\
\text { também, você o Cauê, são muito, muito } \\
\text { bons pra mim. }\end{array}$ & $\begin{array}{l}\text { Em vários aspectos né, no aspecto da dinâmica do } \\
\text { corpo isso é notável é muito bom, a dinâmica. Eu } \\
\text { possuía uma dinâmica hoje eu possuo outra } \\
\text { dinâmica. Com relação à massa corpórea também é, } \\
\text { observo que essa massa ela se diluiu, hoje eu } \\
\text { caminho mais rápido, tenho menos massa corpórea } \\
\text { né. O desempenho circulatório está bom e posso } \\
\text { observar também que com a idade de } 70 \text { anos eu } \\
\text { não digo que o meu desempenho sexual progrediu } \\
\text { mas ele melhorou em qualidade, melhorou bastante. }\end{array}$ & $\begin{array}{l}\text { Eu me sinto até mais segura, segura mesmo, } \\
\text { segura de he...hein nos aspectos de, de, de } \\
\text { mental mesmo de que realmente hãaa...não é a } \\
\text { idade quem me dói, que me dói, sou eu se eu } \\
\text { quiser. Ela, essa experiência com o professor } \\
\text { Cauê, me levantou. }\end{array}$ & $\begin{array}{l}\text { Há, me sinto, me sinto mais } \\
\text { extrovertida, mais confiante. }\end{array}$ \\
\hline $\begin{array}{l}5 \text { - Como está sua relação com } \\
\text { amigos e familiares? }\end{array}$ & $\begin{array}{l}\text { Eu acho que continua a mesma coisa não } \\
\text { mudou muito. (risos) }\end{array}$ & $\begin{array}{l}\text { Muito bom, melhor, é, naturalmente eu já tinha um bom } \\
\text { relacionamento né, mas hoje eu consigo ver o } \\
\text { relacionamento de um outro ângulo, de uma outra maneira, } \\
\text { num é, é! Maneira mais humana, maneira mais pessoais de } \\
\text { relacionamento, dinâmica assim que nos leva a... a } \\
\text { entender o todo, entendeu? Todo, não ficando só em } \\
\text { parte. }\end{array}$ & $\begin{array}{l}\text { Eu gosto de, de amizade, eu gosto de ta relacionando } \\
\text { com pessoas e aqui ampliou. A gente tem } \\
\text { conversado, o email tá sendo um meio fantástico, a } \\
\text { câmera fotográfica, a...a aula em sí, e então são } \\
\text { vários os instrumentos que a gente usa aqui além } \\
\text { dessa brincadeira que parece que é brincadeira. }\end{array}$ & $\begin{array}{l}\text { Ah, continua a mesma coisa, é bom, } \\
\text { é bom, continua bom. }\end{array}$ \\
\hline $\begin{array}{l}6 \text { - E a relação com os colegas } \\
\text { do curso, como você a sente? }\end{array}$ & $\begin{array}{l}\text { Eu gostei muito de, do pessoal desse grupo. } \\
\text { Esse grupo eu acho que é, um, um } \\
\text { entrosamento muito legal com ele, e eu gostei } \\
\text { de todos eles, sem exceção. }\end{array}$ & $\begin{array}{l}\text { Muito boa, muito boa, interessante, respeitosa, madura, e } \\
\text { assim... Gratificante. }\end{array}$ & $\begin{array}{l}\text { Ah, é uma delicia, uma leveza, leveza, gostosura. É, } \\
\text { é, é simpatia, amizade, carinho. }\end{array}$ & Ah, muito, muito bom, ótimo. \\
\hline $\begin{array}{l}7 \text { - O que é esse grupo de } \\
\text { teatro e dança para você neste } \\
\text { momento? }\end{array}$ & \begin{tabular}{|l|} 
E algo assim que eu, que eu tenho algum \\
momento pra extravasar minha...pra dar um \\
extravaso, primeiro extravasar as minhas, \\
minhas emoções, e também aprender, \\
aprender, aprender muito com, com o corpo, \\
com a mente. Eu acho que, eu acho que eu \\
adquiri um pouco mais de concentração \\
naquilo que eu, naquilo que eu faço \\
atualmente.
\end{tabular} & $\begin{array}{l}\text { É um novo grupo de relacionamento, num é? De } \\
\text { compartilhar, de trocar ideias e sair junto, jantar, junto, } \\
\text { almoçar junto se for o caso é isso. }\end{array}$ & \begin{tabular}{|l|} 
Eu acredito que esta é uma experimentação pra mim \\
porque, hã...a gente nunca sabe se a bronquite vai \\
vim mais forte a semana que vem, se a se...(risos) a \\
dor na coluna, mais ai é que tá né, num, num, até \\
hoje hã, nada disso impediu de eu tá aqui a cada \\
hã...semana, e é assim que eu tô pensando. (risos)
\end{tabular} & $\begin{array}{l}\text { É muito importante, uma parte, faz } \\
\text { parte da minha vida, é muito } \\
\text { importante pra mim. }\end{array}$ \\
\hline $\begin{array}{l}8 \text { - O que você achou da } \\
\text { atividade e sua participação } \\
\text { nela? }\end{array}$ & $\begin{array}{l}\text { Foi muito boa a atividade até agora, eu acho } \\
\text { que eu pretendo continuar, vocês vão ter que } \\
\text { me aguentar aqui por um tempo até. E...qual a } \\
\text { pergunta mesmo?... Foi uma atividade muito } \\
\text { prazerosa pra mim, e a minha participação eu } \\
\text { acho que eu, que eu aprendi e também ensinei } \\
\text { alguma coisa. }\end{array}$ & $\begin{array}{l}\text { Bom a atividade como um todo muito boa. A... Desde o } \\
\text { início e e começo de agosto até hoje muito boa, muito } \\
\text { positiva. Bom o meu desempenho eu, eu sou suspeito em } \\
\text { avaliar, fica difícil de você fazer uma autoavaliação né. } \\
\text { Agora posso dizer o seguinte: quem nunca dançou, quem } \\
\text { nunca sambou é, ou quem nunca participou de teatro ou } \\
\text { coisa parecida eu acredito que entre a nota máxima de } 1 \text { a } \\
5 \text { eu tava lá no um e meio ou dois. (risos }\end{array}$ & \begin{tabular}{|l|} 
As atividades são, são formadoras, esclarecedoras e \\
o nosso professor passa isso deliciosamente como \\
um grande líder de grupo, certamente dos demais.
\end{tabular} & $\begin{array}{c}\text { Ai no começo eu tava meio truncada } \\
\text {, né (risos), meio assim acanhada, ai } \\
\text { depois eu fui me abrindo, pondo } \\
\text { sentimento junto com movimento e } \\
\text { foi indo pra frente. }\end{array}$ \\
\hline
\end{tabular}




\begin{tabular}{|c|c|c|c|c|c|}
\hline Pergunta & Voluntário & 8 & 9 & 12 & 14 \\
\hline \multicolumn{2}{|c|}{$\begin{array}{l}1-\mathrm{O} \text { que te levou a fazer } \\
\text { essa atividade }\end{array}$} & $\begin{array}{l}\text { Eu sempre tive essa, essa curiosidade, essa } \\
\text { vontade de trabalhar em teatro, eu tive esse } \\
\text { gosto né. Foi quando uma colega minha me } \\
\text { falou que aqui estavam dando aula de } \\
\text { teatro, eu falei ah! eu vou então, e olha } \\
\text { sinceramente eu estou gostando. }\end{array}$ & $\begin{array}{l}\text { Há foram mui..., várias coisas. Primeiro eu gosto muito de } \\
\text { teatro, segundo eu acho que é muito bom a gente mexer } \\
\text { com o corpo. Ah, terceiro, eu tava procurando um grupo de } \\
\text { pessoas da minha idade com quem interagir. }\end{array}$ & $\begin{array}{l}\text { Bom a princípio eu vim pra conhecer né porque eu } \\
\text { nunca tinha participado de nada. E gostei a gente vai } \\
\text { ficando, vai gostando né, e me fez muito bem, hoje eu } \\
\text { me sinto assim bem melhor do que quando eu iniciei. } \\
\text { Eu pessoalmente entendi, é muito bom pra gente nessa } \\
\text { idade que só fica acostumada a ficar dentro de casa e } \\
\text { tal. E isso mudou muito até o relacionamento da gente } \\
\text { dentro de casa mesmo, faz muito bem }\end{array}$ & $\begin{array}{l}\text { É que eu gosto muito de participar de } \\
\text { teatro, então eu soube que aqui tinha } \\
\text { um bom teatro, um bom professor, } \\
\text { por isso eu vim... Venho para cá e } \\
\text { assistir... Participar. }\end{array}$ \\
\hline \multicolumn{2}{|c|}{$\begin{array}{l}2 \text { - Você já tinha feito teatro } \\
\text { ou dança antes? }\end{array}$} & Nunca. & $\begin{array}{l}\text { Já, eu fiz um curso de teatro em Salvador, morava lá. Com } \\
\text { Firminto Coelho, era, foi um curso baseado em } \\
\text { interpretações, improvisadas e gostei muito. }\end{array}$ & Não & Já. \\
\hline \multicolumn{2}{|c|}{$\begin{array}{l}\text { - O que é essa atividade para } \\
\text { você agora? }\end{array}$} & $\begin{array}{l}\text { Para mim essa atividade é, sei lá, eu tô, eu } \\
\text { sinto que eu estou me realizando, eu sinto } \\
\text { que eu estou mais feliz, mais disposta, mais } \\
\text { alegre. }\end{array}$ & $\begin{array}{l}\text { Hã, pra mim é importante eu pretendo continuar aqui, } \\
\text { porque não só eu acho que a gente aprende a lidar com o } \\
\text { corpo, como hã, a gente percebe que, como a } \\
\text { movimentação corporal é importante, por exemplo eu } \\
\text { francamente Cauê que não fique bravo comigo, mas eu não } \\
\text { pensei que saísse tão bonita a nossa apresentação, que foi } \\
\text { apenas corporal e e corporal sem grandes evoluções né, por } \\
\text { causa da nossa idade. E de repente foi muito bonito, então } \\
\text { é a gente percebe que mesmo na terceira idade a } \\
\text { movimentação do ainda é uma coisa muito bonita. Então } \\
\text { isso eu acho que isso é importante pra gente até pra gente } \\
\text { se perceber enquanto mais velha, quando o corpo não é a } \\
\text { coisa mais bonita do mundo mas a gente tem ainda } \\
\text { movimentações bonitas, sei lá por aí. }\end{array}$ & $\begin{array}{l}\text { Faz falta, faz parte da minha vida, não to conseguindo } \\
\text { ficar sem, entendeu? Eu pensei que eu não quisesse } \\
\text { mais voltar nessa segunda etapa né. Mas num dá pra } \\
\text { ficar, a gente sente a falta, faz parte hoje da, da vida, } \\
\text { entendeu? É muito bom. }\end{array}$ & $\begin{array}{l}\text { Nossa! Tá me trazendo muita alegria, } \\
\text { nossa! To outra pessoa. }\end{array}$ \\
\hline \multicolumn{2}{|c|}{$\begin{array}{l}4 \text { - Você se sente diferente } \\
\text { agora depois que fez essa } \\
\text { atividade? Em que, como? }\end{array}$} & Na disposição. & $\begin{array}{l}\text { É eu percebo mais meu corpo, né. Agora eu, assim eu } \\
\text { percebo mais o meu corpo, isso é um ponto que depende eu } \\
\text { acho que dessa atividade. Ah, a questão da minha, da } \\
\text { minha, meu bem-estar corporal que, que eu tô, bem-estar } \\
\text { corporal eu não sei se posso atribuir só aqui porque ao } \\
\text { mesmo tempo eu recomecei a fazer ginástica com certa, hã, } \\
\text { frequência, né, metodicamente. Eu tô me sentindo muito } \\
\text { bem corporalmente, coisa que não estava no início, né. Só } \\
\text { que realmente fica difícil pra dizer se é apenas por aqui, } \\
\text { com certeza é também por essa atividade, mas mais do que } \\
\text { eu sentir bem eu acho que uma percepção corporal que eu } \\
\text { tenho agora do meu corpo, que é eu acho muito importante } \\
\text { foi adquirida aqui. }\end{array}$ & \begin{tabular}{|l|} 
Hum eu acho que algumas coisas me ajudou muito \\
porque a gente fica dentro de casa só com a família, \\
você não vê o mundo lá fora, né. E sabe, é, num é a \\
mesma coisa hoje, hoje eu consigo ver completamente \\
diferente e sentir que eu posso sair de dentro de casa \\
vim pra cá interagir com as pessoas, num vou fazer \\
falta naquele momento dentro de casa. Porque antes eu \\
pensava que a gente não podia sair de dentro de casa, a \\
gente faz parte daquele mundinho ali, né. Se eu sair \\
vem tudo abaixo a gente pensa assim. E hoje não, eu tồ \\
liberta entendeu, me sinto, liberdade total pra sair, \\
trancar minha casa, sair e vim pra cá e tá aqui \\
inteiramente sem pensar em mais nada. E aconteceu \\
naturalmente de vir todos os dias que tem que vir, \\
interagir com os, os colegas, né. Então eu acho que \\
uma, uma libertação daquele mundinho da gente, \\
daquele dia a dia, daquele cotidiano, entendeu, libera e \\
aqui é outro mundo pra gente, que ajuda em tudo. Até \\
pra sair na rua mudou, muito bom.
\end{tabular} & $\begin{array}{l}\text { Sim, to sentindo diferença, to com } \\
\text { mais disposição e também pra mim } \\
\text { não ficar tão só em casa. }\end{array}$ \\
\hline
\end{tabular}




\begin{tabular}{|c|c|c|c|c|}
\hline $\begin{array}{l}5 \text { - Como está sua relação com } \\
\text { amigos e familiares? }\end{array}$ & Ótima, melhorou bastante. & $\begin{array}{l}\text { Tá bem, tá bem. Não sei se mudou muito, eu tenho uma } \\
\text { boa relação, eu minha família é muito pequena, minha } \\
\text { filha, meu filho, e eu tenho uma boa relação com eles. Não } \\
\text { mudou muito. }\end{array}$ & $\begin{array}{l}\text { Melhor eu acho, que a gente fica mais calma, } \\
\text { entendeu. Assim, porque só enquanto tá lá dentro de } \\
\text { casa estressada, qualquer uma palavrinha já te deixa } \\
\text { nervosa, tira, tira fora da, entendeu, do sério, do nada } \\
\text { eu acho que a gente vai ficando num estado de estresse } \\
\text { tão grande ali dentro e aqui não, você vem, você } \\
\text { relaxa, conversa né, recebe algumas críticas de alguma } \\
\text { conduta ali né. Então você começa a se observar, a } \\
\text { olhar pra dentro e vê que, enxerga seu próprio defeito, } \\
\text { que a gente vê defeito só nos outros, né. E aqui, } \\
\text { conversando, ouvindo, o professor, colegas você } \\
\text { começa a perceber que você tá errado em outras coisas } \\
\text { e começa a se corrigir e isso é maravilhoso. }\end{array}$ & Estão bem, estão muito bem. \\
\hline $\begin{array}{l}6 \text { - E a relação com os colegas } \\
\text { do curso, como você a sente? }\end{array}$ & $\begin{array}{l}\text { Muito boa mesmo, elas são maravilhosas, a } \\
\text { gente se diverte. }\end{array}$ & $\begin{array}{l}\text { Eu as sinto mulheres, mulheres que bom número delas } \\
\text { lutaram, tiveram uma vida difícil, e agora na maturidade na } \\
\text { terceira idade tão se sentindo livres pra fazer coisas que } \\
\text { elas estão gostando, que antes talvez até não pudessem } \\
\text { fazer. E tá sendo um relacionamento muito bom, muito } \\
\text { amigável, muito carinhoso e consequentemente importante. }\end{array}$ & $\begin{array}{l}\text { Muito bom, mais é muito bom, gente, olha é um } \\
\text { momento de descontração que a gente fala tudo o que } \\
\text { tem vontade, a gente dá muita risada, então descontrai, } \\
\text { desestressa, sabe. Olha eu não tenho nem muitas } \\
\text { palavras pra explicar isso, só vivendo mesmo. }\end{array}$ & $\begin{array}{l}\text { Maravilhosamente bem, gosto muito, } \\
\text { tô satisfeita. }\end{array}$ \\
\hline $\begin{array}{l}\text { - O que é esse grupo de } \\
\text { teatro e dança para você neste } \\
\text { momento? }\end{array}$ & Paz, felicidade! & $\begin{array}{l}\text { Olha é uma atividade que eu gosto, me dá prazer de, de, de } \\
\text { fazer, consequentemente, é algo que eu pretendo continuar } \\
\text { fazendo enquanto posso. Acho que é uma das coisas } \\
\text { realmente que me dá prazer atualmente, vir aqui fazer essa } \\
\text { atividade. }\end{array}$ & $\begin{array}{l}\text { É muito especial, faz muita falta quando a gente não } \\
\text { pode vir, entendeu? Então ele torna um momento } \\
\text { muito especial pra vida da gente, tem que vir, } \\
\text { entendeu? Esse é um dia que a gente tira pra isso, faz } \\
\text { parte da nossa vida hoje, é muito bom, é muito } \\
\text { especial pra gente. }\end{array}$ & $\begin{array}{l}\text { Ai, nossa! É uma satisfação imensa, } \\
\text { muito. }\end{array}$ \\
\hline $\begin{array}{l}8 \text { - O que você achou da } \\
\text { atividade e sua participação } \\
\text { nele? }\end{array}$ & Ótima, muito boa. & $\begin{array}{l}\text { Eu acho interessante. Eu, como gosto muito de teatro, eu } \\
\text { estou ansiosa pra usar a voz, né, pra, ou seja pra me } \\
\text { transformar num personagem, mas é uma ansiosidade } \\
\text { muito minha, né. É, eu gosto muito dessa parte do, do, } \\
\text { desse relaxamento inicial, dessa conscientização corporal e } \\
\text { como eu já disse, pra mim isso tá sendo muito importante. } \\
\text { A minha participação na atividade eu acho, eu acho bom, } \\
\text { eu tenho tentado levar a sério, eu faltei um pouco mas na } \\
\text { medida do possível eu tenho levado a sério, e eu sou muito } \\
\text { séria nas atividades que eu faço e né então, eu acho que tá } \\
\text { sendo boa. }\end{array}$ & $\begin{array}{l}\text { Não seu se eu posso me julgar, mas como eu gostei me } \\
\text { fez muito bem eu acho que foi bom. }\end{array}$ & $\begin{array}{l}\text { Nossa! É, pra mim, foi uma novidade } \\
\text { porque não é esse tipo de teatro que } \\
\text { eu fiz, né. Então esse é pra mim... É } \\
\text { novidade e estou muito feliz. Boa, } \\
\text { muito boa. }\end{array}$ \\
\hline
\end{tabular}




\section{APÊNDICE XX}

Estudo da influência da prática com as artes cênicas e atividade autobiográfica e literária no comportamento de uma população com mais de 60 anos de idade.

\section{Voluntário $\quad 5$}

\section{9}

8

6

12

14 $\begin{array}{lll}\text { 1. O que você achou de ter } & \text { O espetáculo a partir da, do Olha, foi muito interessante, } & \text { Ah, eu gostei muito, } \\ \text { participado do espetáculo } & \text { começo do nosso curso, foi sobretudo porque no final a gente vibrei muito, foi } \\ \text { Histórias de Mulheres? } & \text { uma crescente expectativa, conseguiu uma união muito } & \text { maravilhoso o }\end{array}$ com uma realização final, grande e uma, uma emoção muito espetáculo, foi lindo, me senti muito livre, eu me nesse, nesse espetáculo e eu não senti muito bem entrosada. consegui ver muito ele mas Acho que o meu corpo pessoalmente aparentemente ele ficou muito bem, as dores foi lindo, foi muito bom. A gente foram diminuídas, os ficou atrás da coxia na maior parte aquecimentos me ensinaramdas vezes, mas foi muito bom. a fortalecer e me dar melhor condição, postura, brigado.

2. Foi a primeira vez que Eu, num palco, foi a Não, eu já participei outras vezes De teatro foi a primeira você se apresentou para o primeira vez. E eu me e eu pessoalmente gosto muito de vez, eu já me público de teatro? Qual é a surpreendi com a timidez teatro, não só de assistir como de apresentei mas em sensação desse momento? que eu tenho, e ter chegado representar. Olha, eu acho que dança, mas pra teatro até o fim, mas isso se deve esse momento, quer dizer, o foi a primeira vez. sempre a alguém, ao momento da cena, foi muito bom, Nossa, a sensação é incentivo do professor porque na nossa idade, um corpo maravilhosa, eu estava Cauê. Esse momento é de já não tão flexível, não tão bonito, na coxia quando a alegria, é de alegria, é feliz, né. A gente se mostrou primeira entrou, já, a é um momento que me inteiramente livre pra fazer os Carmen entrou já saiu sinto feliz, por tudo isso, movimentos que desejamos e, as lágrimas dos meus

3. A atividade cumpriu a proposta? por ter chegado a, à com disse aqu a incentivo pelo Cauteç, muito incentivo pelo Cauê, né, isso muito bom pra gente, é muito,
muito bom. A gente perder essa muito bom. A gente perder
timidez em função desse exacerbado valor da beleza que existe no Brasil, né, é muito bom.

olhos. Nossa, foi

maravilhoso, eu me

senti bem, com, com os

gestos, com tudo que nós ensaiamos, ah, eu me senti

maravilhosamente bem.

Eu acho que foi exatamente Cumpriu, eu acho que nós nos Cumpriu, cumpriu isso, nos deu segurança, desenvolvemos fisicamente, mesmo. muita segurança, a socialmente. Perdemos um pouco, capacidade de enfrentar a aqueles mais tímidos perderam a crítica, coisa que na nossa timidez e estão mais expostos ao
Eu achei fantástico Ah, eu amei, adorei, desde o Eu achei ótimo, foi uma coisa muito porque desinibe a início até agora no final eu boa pra mim, que eu estava pessoa, desenvolve a sou outra pessoa, tudo precisando mesmo de, dessas pessoa interna que elamelhorou na minha vida, eu parcerias, nós trabalhamos várias é, abre uma encontrei. Eu olho pro semanas. Foi pra mim muito expectativa maior mundo hoje completamente gratificante, eu fiquei mais pras pessoas que diferente, tenho uma visão desenvolvida, o meu físico. Pouca estão vendo, e maravilhosa, a convivência, coisa eu fiz, mas eu fiz com muito desenvolve nossa harmonia muito bom, carinho e amor, estou pronta pra internamente foi tudo de bom. Amei. fazer várias.

também, foi ótimo. año, eu participei de Eu gostei, né, nunca tinha Não, eu já fiz dois tea, aliás, um teatro há muito participado de nada, participei de dois teatros no SESC tempo atrás, e eu participo, e amei. A Pompeia e aqui eu, ai depois

sempre gostei muito. princípio a gente ficou assimterminou e ficou vários, esse tempo Uma sensação muito meio travada e tal, mas com sem participar. E quando eu achei intensa de alegria. o passar do tempo a esse, esta oportunidade e vim com interatividade, a harmonia muito carinho, pra fazer, dar de mim com a gente, amigos, foi o melhor e eu estou muito contente muito bom. Eu acho assim, por isso. É uma sensação assim eu recomendo pra todas, é incrível porque só encontrei gente maravilhoso. boa, amáveis, e o professor também é uma excelente.
Cumpriu muito bem, Olha, pra mim sim eu acho É, cumpriu, foi isso mesmo que eu foi um excelente que foi plena, cumpriu tudo estava procurando pra mim sentir trabalho e eu tô muitodireitinho, hoje eu me sinto mais feliz e tranquila, também pra contente com isso e até bonita, sou capaz de me fazer o trabalho com muito amor tô surpresa comigo sentir até bonita, tô muito 
idade é impossível,

mundo lá fora.

praticamente impossível, e

hoje a gente deixa, pode

criticar, então que mais que

eu quero disso, só isso

muito obrigado.

4. Você deseja continuar

Eu desejo continuar e quero Ah, claro, num tem dúvida,

que haja possibilidade pra inclusive porque esse é um

outras pessoas, porque o trabalho que não deve ser

bem que me fez eu tenho interrompido. Um trabalho com o

vontade que outros possam corpo, trabalho com a cabeça,

ter.

então a gente não pode parar, não

podemos parar. mesma.

mais segura e, sabe,

completamente diferente do

início, né. Cheguei aqui toda

tímida, toda assim, e hoje

não, hoje eu me comunico

muito bem e me sinto bem a

vontade, é ótimo foi ótimo,

cumpriu tudo direitinho foi

maravilhoso.

Claro, sem dúvidas . Sim, com certeza

Eu desejo ficar até quando o professor me despedir. 


\section{ANEXOS}

PEÇAS de DIVULGAÇÃO

E

MATÉRIAS DE JORNAL 


\section{ANEXO I}

Flyer divulgação para recrutamento de voluntários

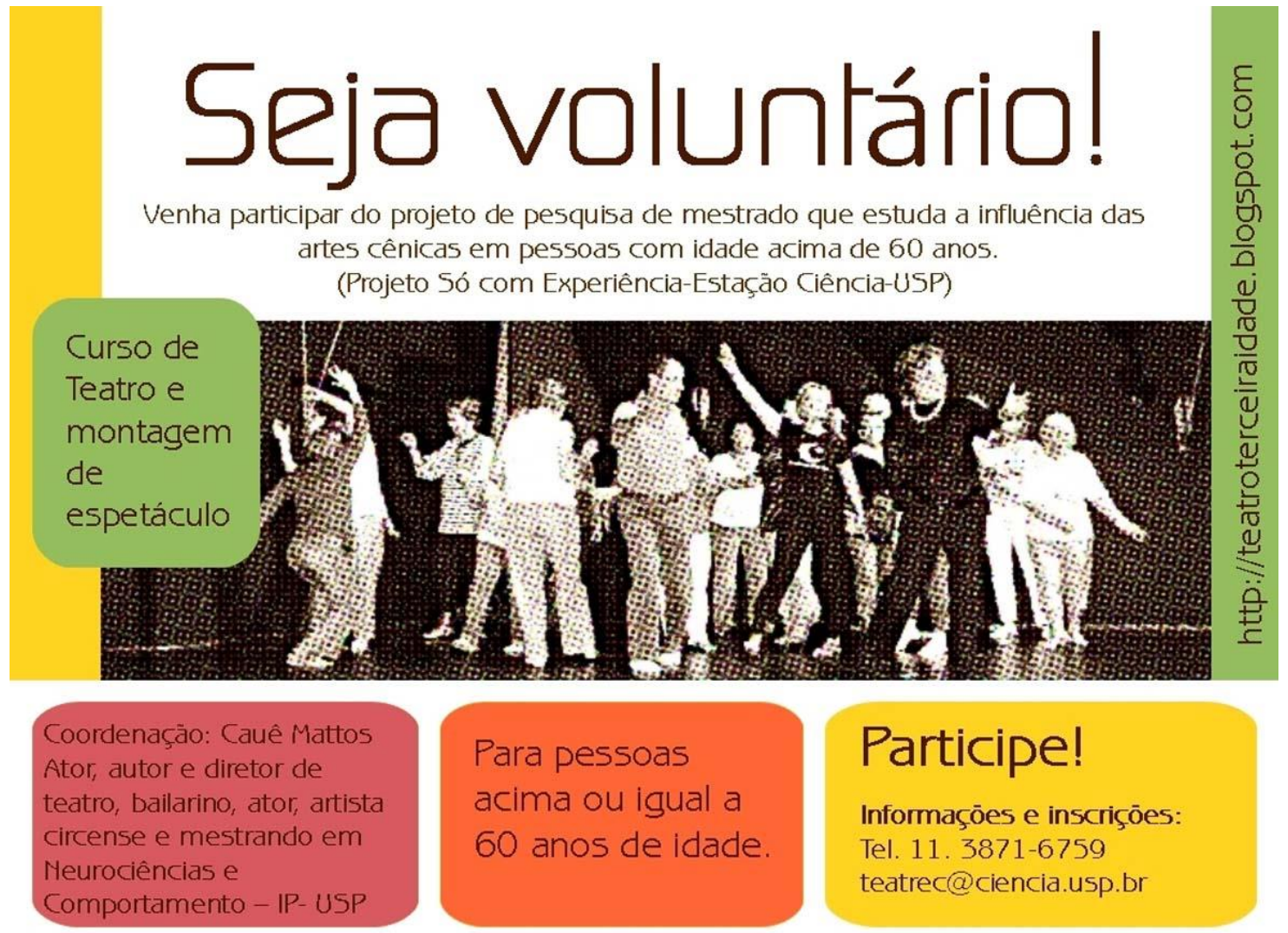


ANEXO II

\section{Divulgação no site da PrCEU-}

Estação Ciência abre inscrições para oficinas de teatro para idosos

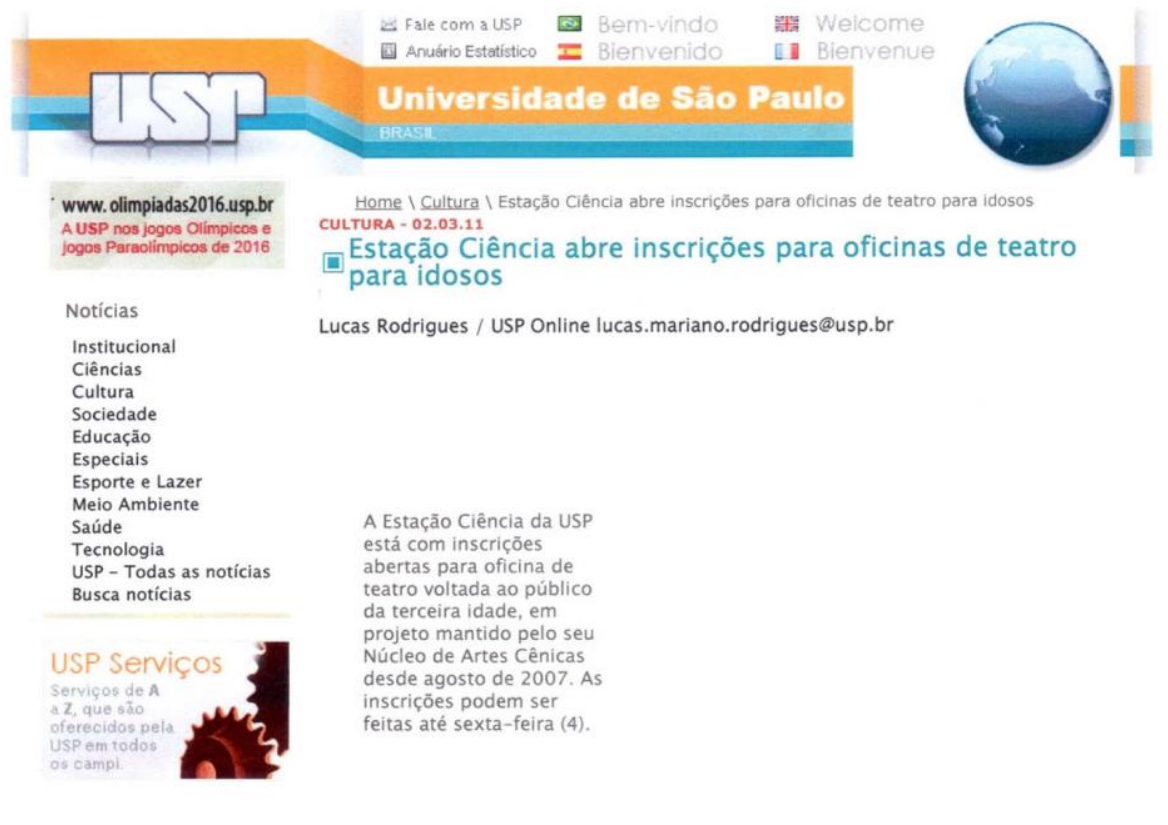

Com coordenação de Cauê Mattos, ator e diretor de teatro, e integrante do Núcleo, a oficina surgiu com o objetivo de desenvolver atividades para integrar o público da terceira idade, que até entăo não participava muito das iniciativas da Estação. A oficina terceira idade começou a ser habitual no cotidiano da Estação. "A participaçãáo é total", afirma o diretor.

As oficinas são ministradas, atualmente, às quartas e às quintas-feiras. Como o intuito de aumentar o oferecimento ao público, a partir da nova turma os encontros intuito de aumentar ố

Metodologia

Durante as aulas, são trabalhados diversos Durante as aulas, sào trabal hados diversos enquanto estratégia cênica es composiçōes de cenas até a montagem de peças e espetáculos. Entre os trabalhos já apresentados pelas turmas, estão as peças "O pagador de promessas", de Dias Gomes. "Sonhos de uma Noite de Verão", de William Shakespeare.

O processo de elaboração dos espetáculos, como a pesquisa sobre a época, o autor e os

montagem dos cenários e a preparaçăo dos palcos, é todo organizado pelos participantes da oficina, que se reúnem em grupos e resolvem todas as questōes relacionadas à produção das peças. "O resultado é um espetáculo deles", diz Mattos.

Pesquisa

De acordo com Mattos, uma das ideias iniciais da oficina era a observação do desenvolvimento do corpo dos idosos através da prática do teatro. "O interesse sempre foi olhar para esse corpo e suas possibilidades". Além disso, o estímulo ao envolvimento social dos participantes, assim como a sua saúde, também estiveram presentes durante todo esse tempo.

Posteriormente, com as atividades mais definidas, Mattos decidiu transformar essa análise, que acontecia de maneira informal, em uma pesquisa de mestrado. A partir disso, passou a estudar como o oferecimento dessa prática influencia na convivência, nas relaçōes sociais e pessoais, no compartilhamento de ideias, entre outros aspectos.

$\mathrm{O}$ que $\mathrm{O}$ ator conseguiu constatar até agora é que aquelas pessoas que chegavam, muitas vezes, com dores no corpo, já apresentaram melhoras. Segundo ele, à medida em que faziam os exercícios, até mesmo a postura dos participantes mudou.

Inscrições

Para participar da oficina, é necessário se inscrever gratuitamente na Estaçăo Ciência, até sexta-feira (4), das 10 às 17 horas, ou pelos telefones (11) 3871$6750 / 7421-6246$, ou email cauezambele@gmail.com .

O primeiro encontro acontecerá no dia 15 de março.

A Estaçăo Ciência fica na Rua Guaicurus, 1394, Lapa, São Paulo. 


\section{ANEXO III}

Divulgação da apresentação "Histórias de Mulheres" no

Clube Alto de Pinheiros
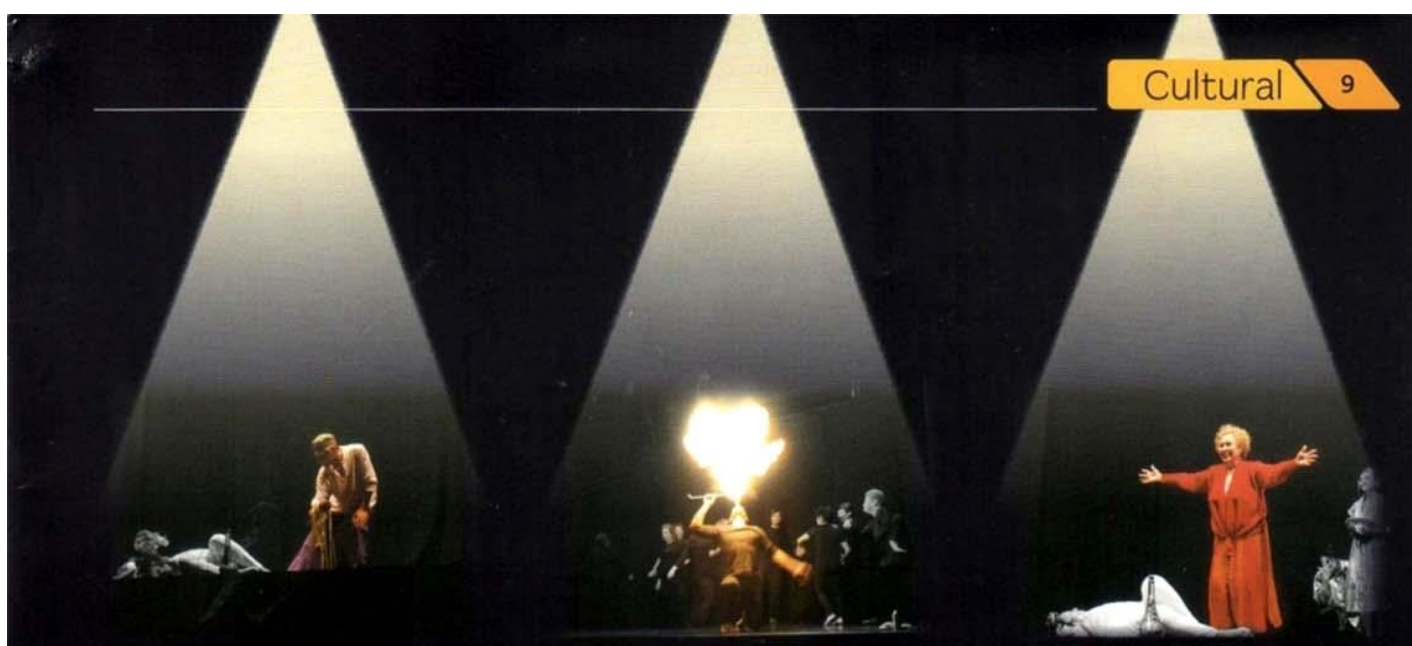

\section{A poética do corpo}

Clube AP recebe dois espetáculos do projeto "Só com Experiência" do Núcleo de Artes Cênicas da Estação Ciência - USP, voltado para pessoas com mais de sessenta anos de idade.

TÍTULO DAS PEÇAS:

"Ver São Muitos" e "Paixão e Eternidade"

No dia 02 de outubro, os alunos do projeto "Só Com Experiência", voltado para pessoas com mais de 60 anos, do Núcleo de Artes Cênicas da Estação Ciência - USP fazem duas apresentaçōes no palco do Clube AP numa mesma tarde. Com o título Ver São Muitos, a primeira peça tem inicio às $16 \mathrm{~h}$ e foi construida com base numa fábula sobre a migraçāo de um bando de pássaros, em que um deles se fere e nāo pode seguir viagem. "A peça é uma criação coletiva e seu próprio nome está relacionado á quantidade de versões que criamos sobre o mesmo assunto, antes de finalizar o espetáculo comenta o orientador cênico do grupo, Cauê Mattos Partindo da fábula, aborda aspectos como solidariedade, recuperação, ajuda mútua, reproduzidas de maneira análoga

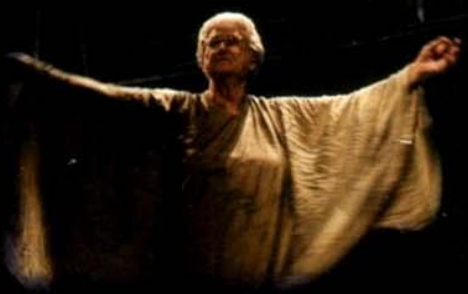
em situacões do cotidiano humano

A segunda peça da tarde, Paixão e Eternidade, se desenrola como uma performance corporal sem palavras. De acordo com Cauê, o grupo utiliza elementos da dança contemporânea para criar cenas em que os atores dialogam entre si, promovendo uma troca mútua de sentimentos e sensações. resultando em criaçōes corporais únicas. Vale a pena assistir

Dia $02 / 10(\mathrm{Dom})$ as $16 \mathrm{~h}$ Gratuito Mais informacoes no Departamento Cultural 


\section{ANEXO IV}

Divulgação da apresentação "Histórias de Mulheres" no

Revista Carta Capital

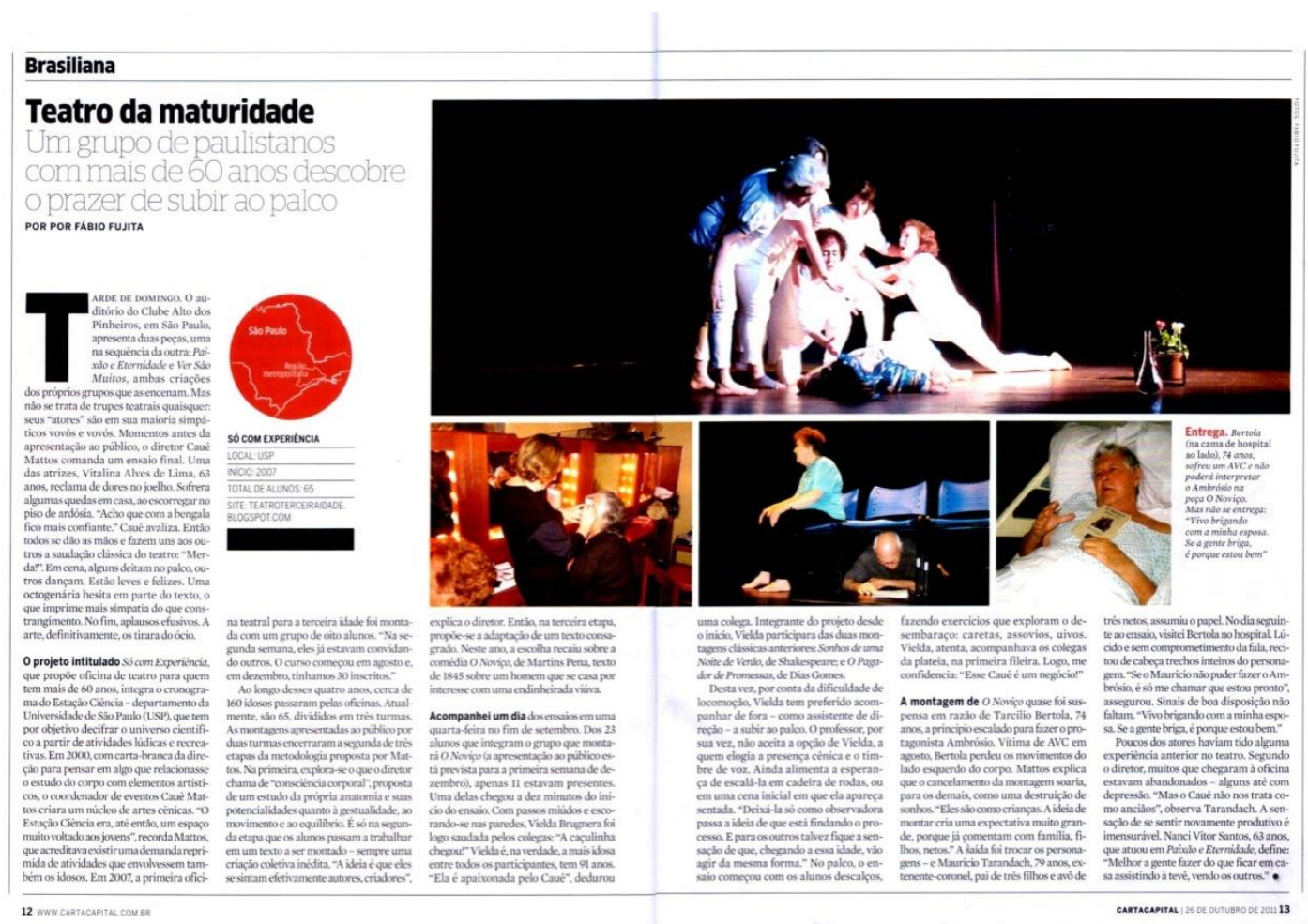


ANEXO V

Divulgação do projeto Diário Oficial

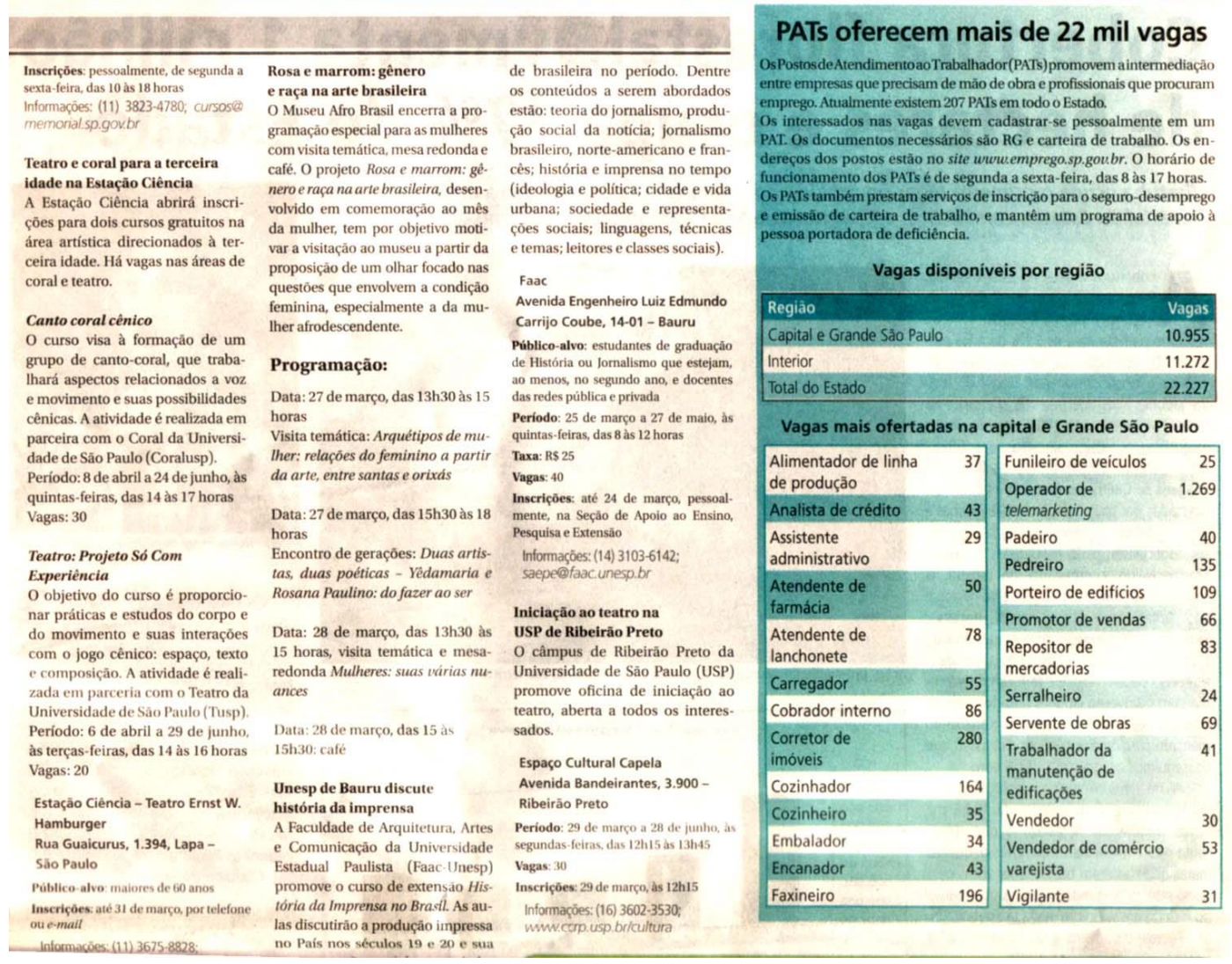




\section{ANEXO VI}

Revista da Folha - 03/05/2009

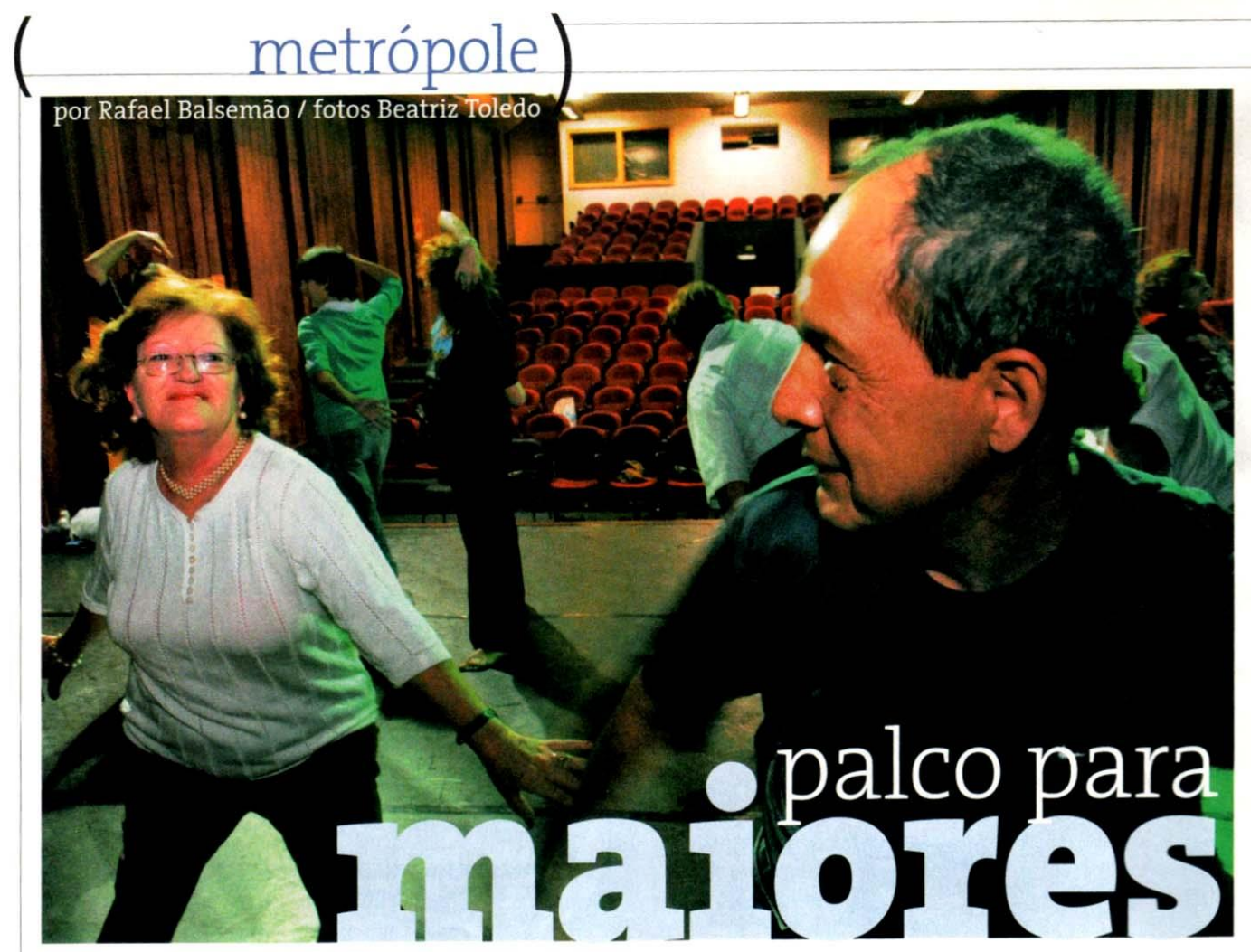

COM MAIS DE 6O ANOS, ELES DESCOBREM NO TEATRO UMA FORMA DE REJUVENESCER
O rejuvenescimento começou com o papel dopersonagem Guarda, em uma encenação de "O Pagador de Promessas", de Dias Gomes, no ano passado. O figurino foi ele mesmo quem montou, com direito a farda, botina e cacetete, comprados por $\mathrm{R} \$ 50$ em uma loja de artigos para policiais.

A apresentação única marcou uma nova fase na vida do aposentado, depois de 31 anos como técnico em telecomunicações na antiga Telesp. "Foi espetacular. Estou me descobrindo", afirma ele, um dos 30 alunos de um curso de teatro para a terceira idade realizado na Estação Ciência, da USP, na Lapa. Assim como ele, a maio- ria dos colegas passou dos 60 As aulas, gratuitas, acontecem nas tardes de quarta-feira, durante três horas. O grupo é coordenado por Cauê Mattos, 46. É a primeira vez que o ator e diretor assume o papel de professor. De cara,encontrou uma galeracheia de especificidades. "O corpo não responde na mesma velocidade”, explica Cauê. “Temos que respeitar." Na fila de espera para participar do grupo, 80 pessoas.

Algunsalunos têm tratamento especial, como Vielda Brognera, 88 , que, no passado, chegou a fazer um vestido para a atriz Cacilda Becker, mito dos palcos nacionais. Com dificuldade para andar e enxergar, ela não participa de exercícios que exijam 
muito do corpo. Mora sozinha na Água Branca e tem um ajudante que a leva para as aulas.

"E uma terapia. Amo o Cauê. Qualéojovem quegosta de me ninas de 80 para cima?", brinca

Vielda. Naapresentaçãodefina de curso no ano passado, ela as sumiu a assistência de direção. O professor é só elogios para sua "menina": "Ela já veio para a aula gripada e doente".

As tarefas não acabam durante o encontro semanal na Estação Ciência. Todos têm de fazer a lição de casa -no momento, uma pesquisa sobre teatro elizabetano. "Eu cobro.
Não penso: 'Ai, coitadinho do velho"', diz o professor.

Frequentar as aulas, para uma grande parte dos alunos, significa retomar sonhos. "Sempre quis ser artista, ia ao circo, representava no colégio", recorda-se Maria Lúcia Beijós, 64, dois casamentos e o desejo de se tornar uma artista interrompido na primeira união. "Venho para cá feliz, para ver meus amigos e colocar para fora tudo o que eu sinto."

Malu soube da existência do grupo teatral pelo rádio em 2007 , quando ficou viúva pela segunda vez. No mesmo ano, mais informacões sobre os cursos

Estacăo Ciência

Tel. 3673-7022/3675-8828

http://teatroterceiraidade.blogspotcom

Associação dos Funcionários Públicos

Tel. 3293-9579/3293-9580/3293-958

Centro do Professorado Paulist

Tel. 3340-0500/3340-0503

Espaco Conexão - Shopping Eldorado Tel, 2197.7815

Teatro dos Arcos

Tel. $3101-7802$

Curso Pró-Ser - Teatro Escola Macunaima (para quem nåo quer ser ator)

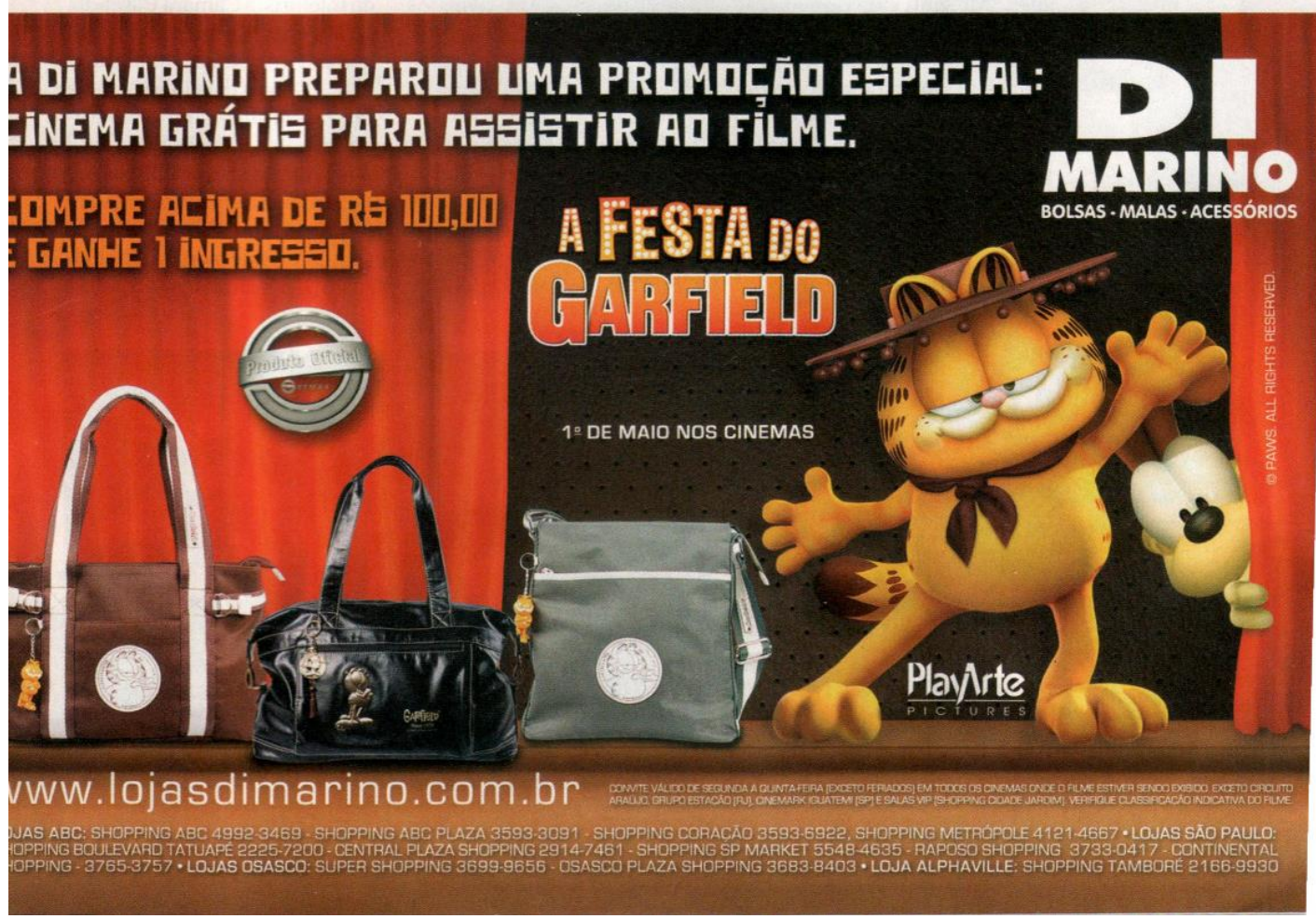




\section{GLOSSÁRIO}

Esta seção objetiva facilitar a leitura por múltiplos públicos, para os quais este trabalho se destina e cuja característica se configura como inter, multi e transdisciplinar.

Área de associação - áreas corticais responsáveis pelo processamento e integração de informações sensoriais e respostas motoras, emocionais, comportamentais e cognitivas.

Áreas de Brodmann - organização citoarquitetural dos neurônios corticais, definidas e catalogadas pelo anatomista Korbinian Brodmann, às quais são atribuídas funções diferenciadas?.

Atitude - maneira psicológica ou moral de enfrentar uma questão.

Atitude do ator - relativo à postura do ator diante da cena e aos outros atores.

Autonômico - relativo ao Sistema Nervoso Autônomo (SNA) ou neurovegetativo, parte do sistema nervoso periférico, que atua sobre as funções vegetativas: vísceras, vasos sanguíneos e glândulas.

Bioenergética - terapia criada por Alexander Lowen que combina o trabalho corporal com o mental, para auxiliar as pessoas a compreenderem seus problemas emocionais e concretizarem, o mais que puderem, seu potencial para o prazer e a alegria de viver.

Cognição - processo mental que possibilita tomar consciência de si mesmo e do mundo.

Comportamento - atitudes e expressões manifestadas pelos indivíduos como respostas do sistema nervoso a estímulos externos ou internos.

Conexão neuroanatômica - área de contato entre o axônio do neurônio anterior e o soma ou dendrito do neurônio posterior.

Contato improvisação - estilo de dança contemporânea, caracterizada como Nova Dança, baseada no toque e na expansão das percepções, para o desenvolvimento de um diálogo físico profundo e espontâneo entre os bailarinos.

Corporeidade - maneira pela qual o cérebro reconhece e utiliza o corpo como instrumento relacional com o mundo, ou seja, é o conjunto das significações vividas.

Criação coletiva - processo de construção do espetáculo em que o texto é gerado pelo jogo dos atores que, guiados ou não por um diretor, debruçam-se sobre um tema, uma história ou qualquer outro tipo de material.

Deambulação - andar ou caminhar despretensiosamente.

Desordem somática - relativa à sobreposição de diversos desequilíbrios do organismo, caracterizados, principalmente, por sintomas, sofrimento e incapacidade física e mental.

Educação somática - campo disciplinar que reúne um conjunto de métodos que tem como principal foco o aprendizado da consciência do corpo em movimento.

Encéfalo - parte do sistema nervoso, compreendendo o cérebro, cerebelo, ponte e medula oblonga.

Encenação - ato ou efeito de por em cena, montar um espetáculo teatral.

Encenador - aquele que concebe e dirige a montagem de uma peça teatral.

Envelhecimento ativo - termo adotado pela Organização Mundial da Saúde e que se refere ao processo de otimização das oportunidades de saúde, participação e segurança, com o objetivo de melhorar a qualidade de vida à medida que as pessoas ficam mais velhas.

Espaço cênico - espaço definido em função de uma encenação teatral, de dança, ópera ou circo.

Evocação - aquilo que pode ser requisitado a qualquer momento por meio da memória. 
Filogenética - relativo ao estudo da relação evolutiva entre grupos de organismos vivos, que é descoberta por meio de sequenciamento de dados moleculares e matrizes de dados morfológicos.

Gesto - (PAVIS, 2008) - movimento corporal, na maior parte dos casos voluntário e controlado pelo ator, produzido com vistas a uma significação mais ou menos dependente do texto dito, ou completamente autônomo.

Gestual - relativo à gestualidade e à poesis advinda dela.

Holístico - aquilo que é totalizante, abrangente.

Homeostasia - propriedade dos organismos vivos de manter em equilíbrio dinâmico as funções fisiológicas.

Ideokinesis - (Ideo: ideia; Kinesis: movimento, ou movimento imaginado) método educacional que se utiliza de imagens para remodelar o sistema neuromuscular.

Improvisação em teatro - algo realizado e concebido pelo ator . no momento da ação presente, sem preparação previa.

Interface - recurso que estabelece a adaptação entre dois ou mais sistemas diferentes.

Intervenção - forma contemporânea de atuação cênica ou de outra modalidade artística caracterizada por ser pontual e realizada em espaços alternativos.

Jogo (teatro) - relativo à atuação do ator.

Labanotation (ou Kinetography Laban) - é um sistema de notação para gravação e análise de movimento humano elaborado pelo coreógrafo Rudolf Laban.

Localizacionista - conceito neuroanatomico segundo o qual as funções do cérebro são desempenhadas por regiões, estruturas ou núcleos específicos.

Marcador somático - hipótese neurocientífica, formulada por Antônio Damásio, que propõe um mecanismo cujo processo emocional pode guiar (ou influenciar) o comportamento, principalmente a tomada de decisão.

Memória - processo neural que inclui aquisição, retenção, esquecimento, consolidação e evocação de informação.

Memória explícita ou declarativa - memória que pode ser descrita por palavras, tais como lembranças de acontecimentos específicos e de aspectos gerais.

Memória implícita ou não declarativa - memória que inclui procedimentos e habilidades motoras, hábitos e regras, que não pode ser descrita por palavras.

Memorialista - aquilo que é baseado em fatos e lembranças pessoais.

Memória primordial - hipótese elaborada por Antonio Damásio que relaciona o tronco cerebral como primeira base para o cérebro construir mapas neurais "dos sentimentos mais primitivos".

Mnemônico - que diz respeito memória.

Modulação - ação temporal mediada por agentes moleculares sobre os canais iônicos

Motivação - condição do organismo que impulsiona a geração de comportamentos.

Neurociências - estudo científico inter- e multidisciplinar do sistema nervoso e suas manifestações.

Neurotransmissor - substância molecular sintetizada pelo neurônio e liberada no espaço extracelular para transmitir informação entre os neurônios ou seus alvos.

Neurônio-espelho - célula que é ativada apenas quando o indivíduo realiza movimentos a partir da observação de movimentos executados por outra pessoa.

Oficina- curso não oficial de curta duração.

Ontogênese - que diz respeito ao desenvolvimento biológico.

Performance (artes cênicas) - expressão artística que combina elementos das artes cênicas, das artes visuais e da música.

Performance física - desempenho funcional do indivíduo. 
Pesquisa cênica - estudo e prática de recursos e técnicas cênicas dirigidas a uma concepção espetacular e autoral.

Plasticidade neural - capacidade do sistema nervoso de se modificar estrutural e funcionalmente em função das condições propiciadas, vigentes.

Presença (teatro) - quando o ator dá ao público a impressão de viver em um eterno presente, cativando sua atenção e identificação.

Produção (teatro) - realização executiva de preparação e montagem do espetáculo.

Propriocepção - propriedade somestésica que registra as posições estática e dinâmica do corpo, articulações e músculos, de forma consciente ou inconsciente, auxiliando também na percepção espacial e tridimensional.

Prosódia (artes cênicas) - relacionada à acentuação vocálica de um verso com o intuito de valorizar o texto.

Prosódia (neurociências) - habilidade de interpretação e decodificação do conteúdo linguístico das sentenças emitidas, bem como das expressões de atitudes e emoções a elas vinculadas.

Psicossomática - área de conhecimento interdisciplinar que integra diversas especialidades da saúde, para estudar os efeitos de fatores sociais e psicológicos sobre processos orgânicos do corpo e sobre o bem-estar das pessoas.

Qualidade de vida - conceito metodológico que mensura as condições de vida de um ser humano em relação ao bem espiritual, físico, mental, psicológico, emocional, de relacionamentos e usufrutos sociais.

Semântica - relativo ao significado de algo. Incide sobre a relação entre significantes (palavras, frases, sinais e símbolos) o que eles representam, a sua denotação

Senescência - processo biológico natural do envelhecimento.

Senilidade - processo de declínio gradual e constante da morfofuncionaliade de todos os sistemas orgânicos do corpo, acompanhado de desorganização mental e dificuldades em todas as partes do corpo, como nos sistemas cardiovascular, respiratório, musculoesquelético, nervoso, urinário e imunológico.

Sinapse - espaço de contato entre duas células neuronais ou entre o neurônio e a celula muscular, entre neurônio e célula epitelial glandular por onde a transmissão da informação neural acontece.

Sinestesia - Sensação secundária que acompanha uma percepção.

Sistemas orgânicos - relativo a grupos de órgãos que, juntos, executam determinada tarefa.

Sistêmica - relativo à compreensão de um organismo em relação com o todo ou com seus diferentes sistemas morfofuncionais.

Sistema Límbico - Sistema relacionado com a regulação dos processos emocionais e do comportamento. Ele é formado principalmente giro do cíngulo, giro parahipocampal e hipocampo.

Sistema Motor - sistema de interações entre vários componentes do sistema nervoso relacionados à coordenação e execução de atos motores.

Somestesia (soma, que quer dizer corpo, e aesthesia, que significa sensibilidade) - é a capacidade do ser humano e animais de perceber informações sobre as diferentes partes do seu corpo.

Subjetividade - diz respeito ao universo constituinte do indivíduo (mundo íntimo), pelo qual ele se relaciona com o ambiente (mundo externo).

Transdução - capacidade do neurônio de captar os estímulos do ambiente (mecânicos, eletromagnéticos, químicos etc) e transformá-los em impulso elétrico ou potenciais de ação, excitatórios ou inibitórios. 


\title{
Local de realização da pesquisa
}

\author{
Teatro Ernst W. Hamburger
}

Estação Ciência - USP

São Paulo - SP

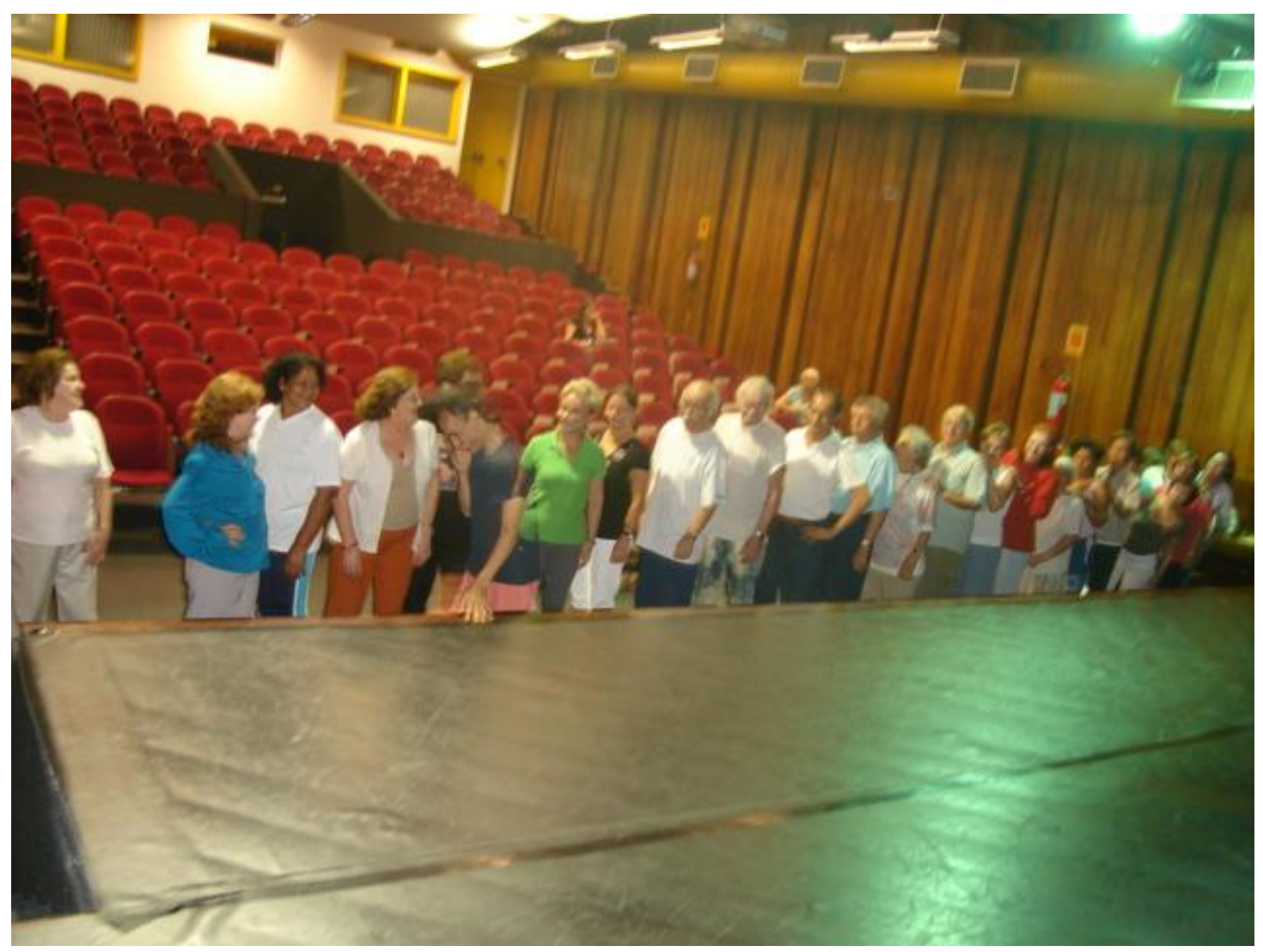

Figura 26. Fotografia do Teatro Ernst W. Hamburger. - Estação Ciência - USP e participantes do Projeto Só com Experiência. Fonte: arquivo NACEC . (2008). 